
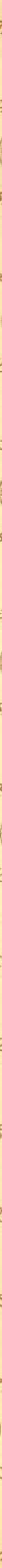


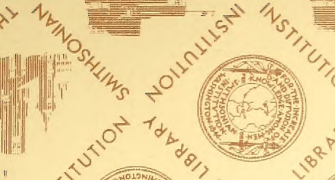
(19:1)

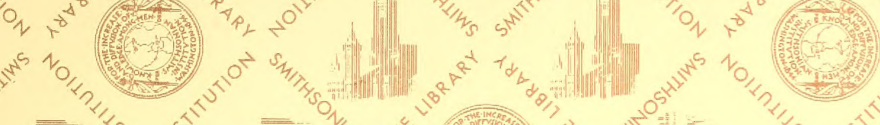

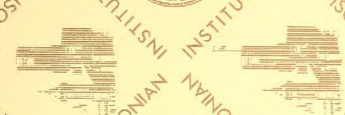

$(9)=3$

2.

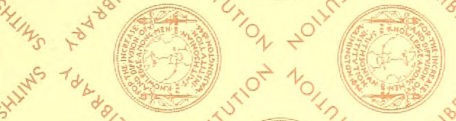

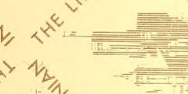

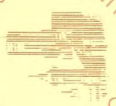

(5i)
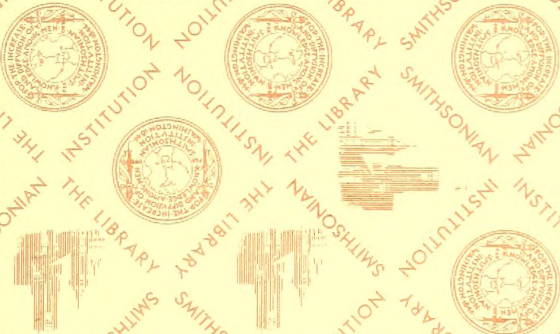

(1)
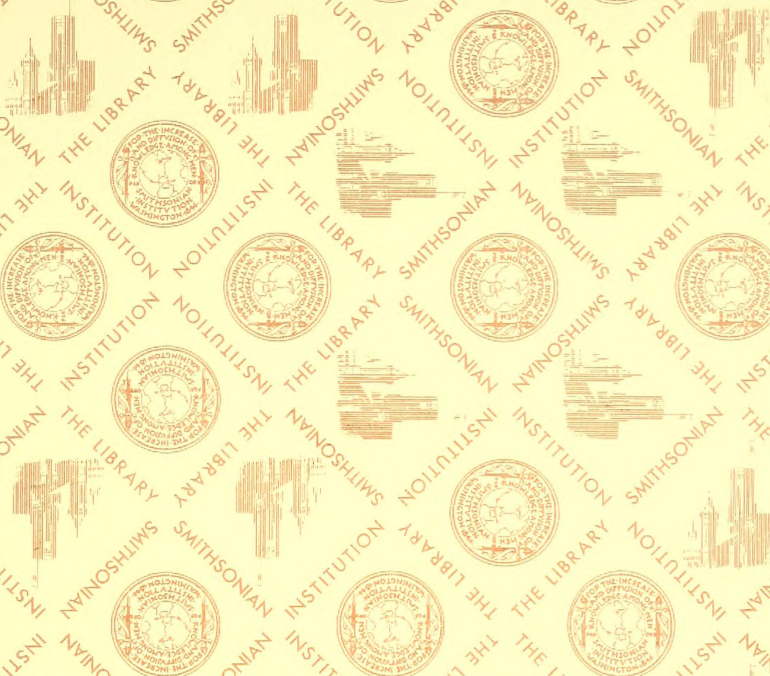

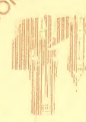
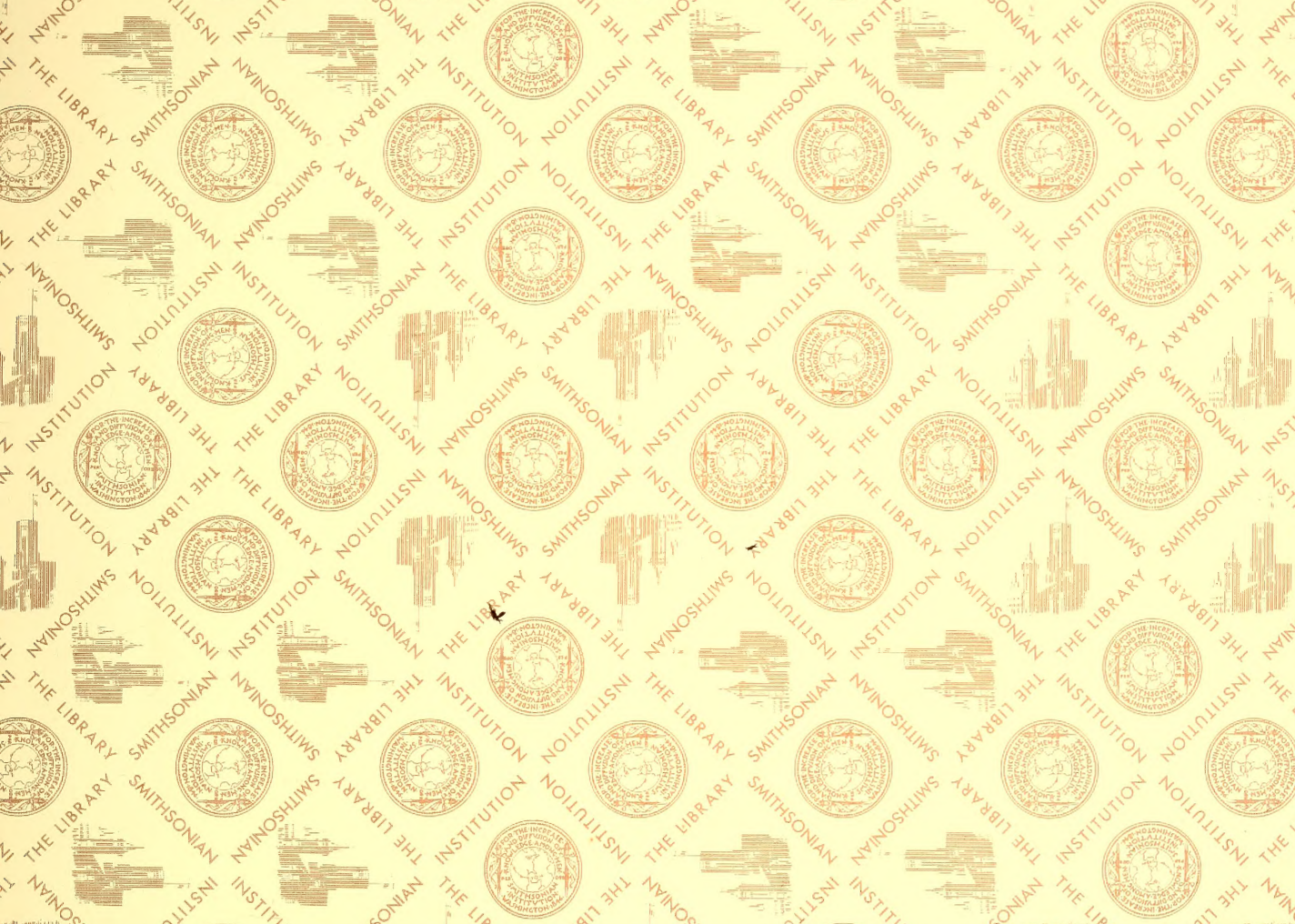

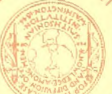

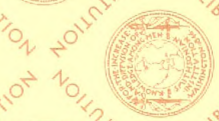

ify
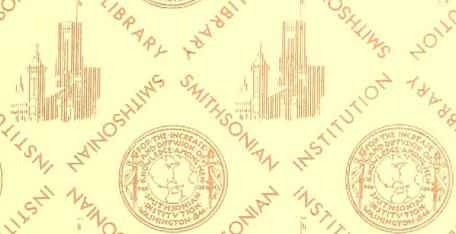

it
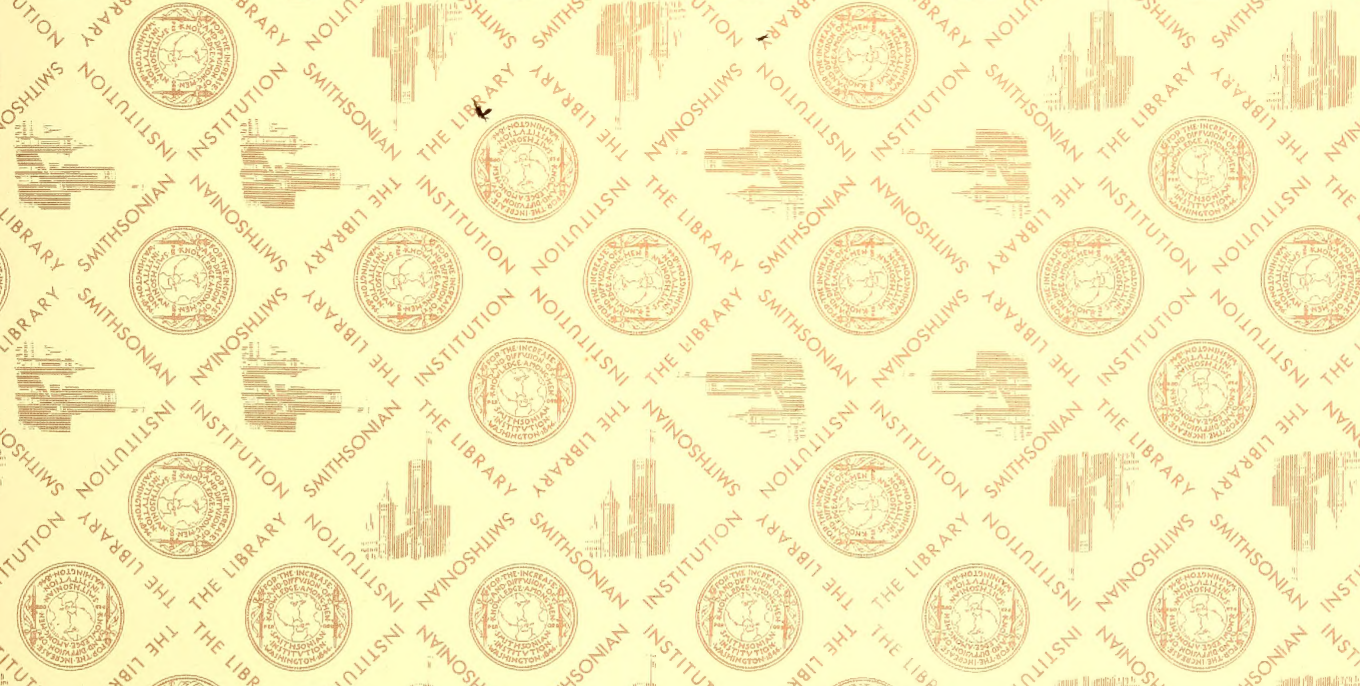

H
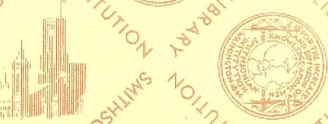

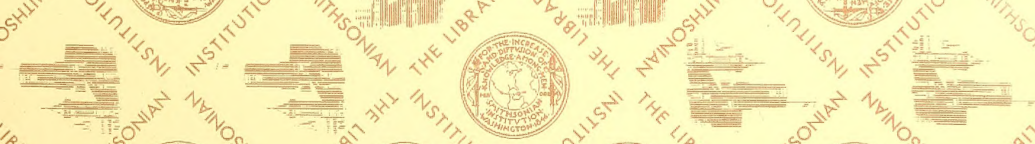
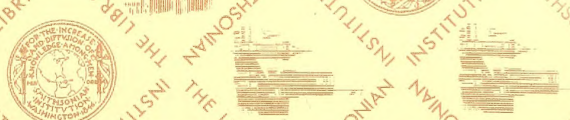

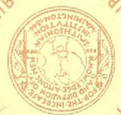
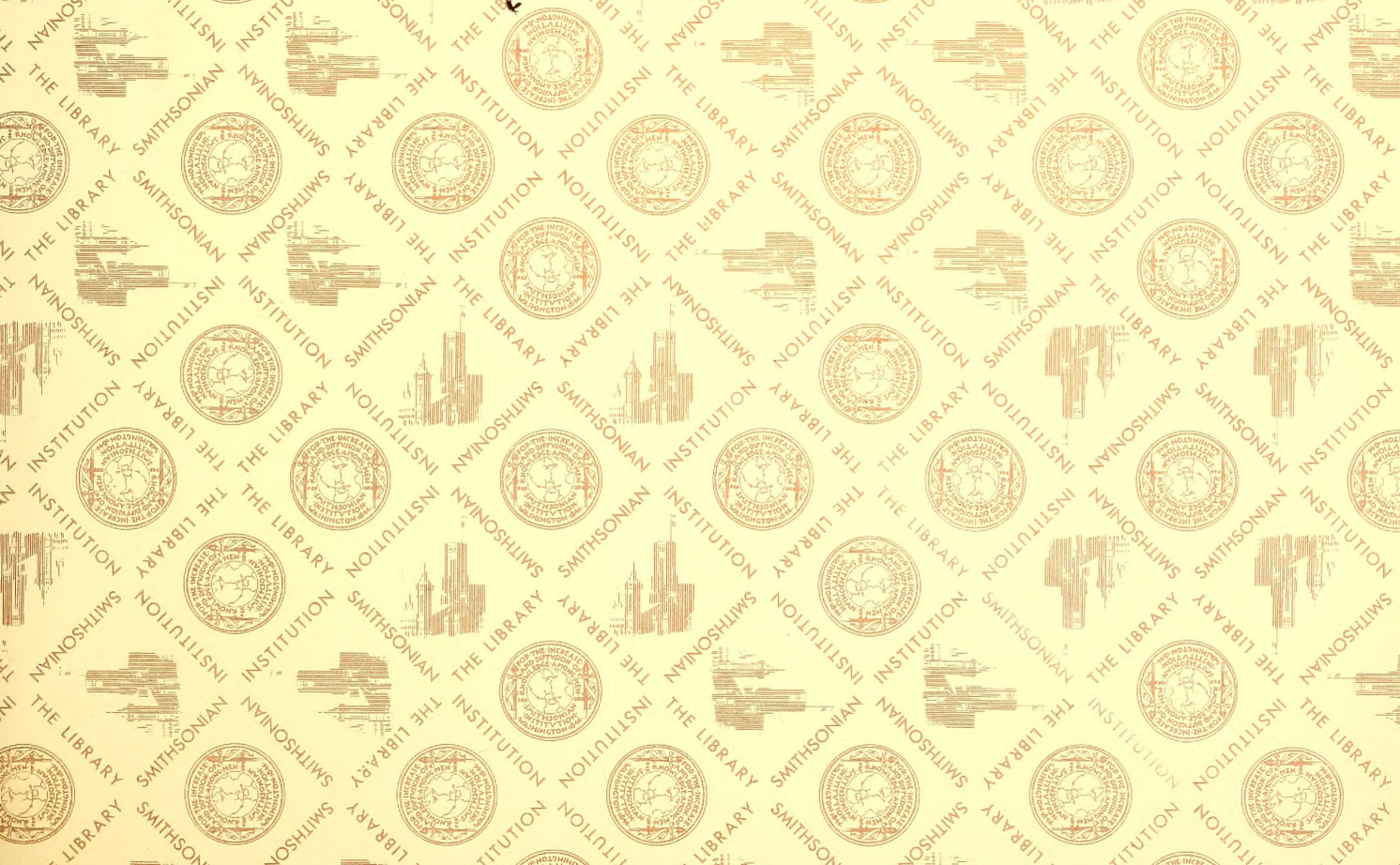





\section{PART I.}

\section{HISTORY OF THE INTRODUCTION}

OF

DOMESTIC ANIMALS AND PLANTS. 



\section{TO THE READER OF THIS \\ VOLUME}

Kindly handle this book with the utmost care on account of its fragile condition.

The binding has been done as well as possible under existing conditions and will give reasonable wear with proper opening and handling.

Tour thoughtfulness will be appreciated 



\section{U N I T E D S T A T E S \\ EXPLORING EXPEDITION

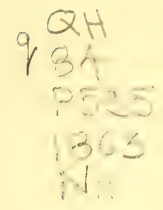 \\ DURING THE YEARS \\ 1838, 1839, 1840, 1841, 1842. \\ UNDER THE COMMAND OF \\ C H A R L E S W I L K E S, U. S. N. \\ V 0 L. X V.}

T H E

GE0GRAPHICAL DISTRIBUTION

OF

\section{A N IMALS AND PLANTS,}

BY

\section{CHARLES PICKERING, M. D.,}

MEMBER OF THE SCIENTIFIC CORPS ATTACHED TO THE EXPEDITION.

B OSTON:

G O U I A N D LINCOIN,

59 WASHINGTON STREET.

LONDON : TRÜBNER AND COMPANY.

1863 . 
PHILADELPHIA

c. SHE R A $N$, PRINTER,

19 St. James Street.

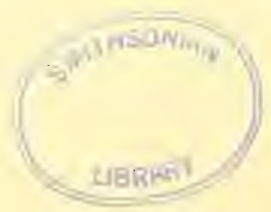




\title{
GEOGRAPHICAL DISTRIBUTION
}

\author{
oF

\section{A N I M A L A N D P L A N T S.}

CHAPTER I.

ANIMALS AND PLANTS REMOVED FROM THEIR NATIVE LOCALITIES

BY THE HAND OF MAN.

IN taking up the subject of the Geographical Distribution of species, it will at once be perceived, that human interference must be taken into consideration; the face of nature having been greatly changed by the removal of the forest, the cultivation of the soil, and the introduction and dissemination of foreign animals and plants.

Detached observations, tending to show the amount of this interference, are given in the twenty-first and succeeding chapters of my Races of Man. To extend similar observations to all the countries of the globe, seems an endless task; and it becomes necessary, with the accumulation of facts, that some general plan should be adopted in arranging the results.

On reflection, the subject of the introduction of foreign animals and plants, will be found to resolve itself into tracing out the history of each species. A list will, therefore, naturally assume the chronological order: and Egypt, from its containing the earliest records of the human family, and from its geographical position and other collateral circumstances, becomes the most convenient country for a point of reference. 
In the following pages, the species unknown in Egypt are inserted in notes. The chronological order is thus preserved, while the remarks are rendered capable of indefinite extension. This permits other countries to be included; and the plants and animals introduced by Polynesians and aboriginal Americans along the isles and shores of the Pacific, to be brought under investigation in connexion with their native names.

The observations embraced in this and the preliminary chapters, are to be regarded as an introduction to the volume on Geographical Distribution prepared during the voyage of the Expedition. The ground must first be cleared of sources of error, before we can arrive at a view of the real order of Nature.

\section{THE NATURAL CONDITION OF EGYPT.}

To a stranger accustomed to lands clothed with vegetation, Egypt presents a most uninviting aspect. An upland waste of bare lightcoloured soil, save only upon the bottom of the narrow trench formed by the river and within reach of its overflow. After leaving the vicinity of the Mediterranean, this interminable waste appears on a general view to be entirely devoid of vegetation: but plants can be found by searching for them; and these Desert plants, of less than a hundred kinds, and in general not remarkable in their appearance, constitute all that is Botanically interesting in the flora of Egypt.

In striking contrast with the Desert, the bottom of the river-valley, or the river-flats, have been always thickly covered with grasses and other herbaceous and humble plants. Traces of the original growth may still be distinguished: the species being few, and of European affinity; and notwithstanding the warm latitudes, Tropical forms, even in the Thebaid, are rare and inconspicuous.

In these two phases of Egyptian vegetation, the only tree appears to have been a willow (Salix), growing sparingly along the riverbrink; and perhaps the only shrubs, an occasional tamarisk, and a low bushy Acacia, both belonging to the Desert.

On closer examination, the powdery soil is found to be devoid of Mosses, Ferns, and Lichens (the exceptions being, two or three Mosses in the walls of cisterns, the Adiantum capillus veneris along the Mediterranean, and a few Lichens in elevated situations, chiefly on the tops of the Pyramids): other tribes abounding in Europe are also 
absent, as the Saxifragacea, the Droseracea, the Primulacea, the Violaceo, the Valerianaceo, the Gentianacea (the genus Erythræa being excepted), the Orchidacea, perhaps the genus Carex, the Onagracea, the Hypericacex, the Globulariaceae (a species along the Mediterranean being excepted), the Crassulacea, the Dipsacacere (a Scabiosa along the Mediterranean being excepted), the heaths and whole tribe of the Ericacea, and the Rosacece (with the exception of a Poterium, growing near the Mediterranean in the Desert).

The Egyptian flora will be found to be extremely simple. Zygophyllacea (so peculiarly a Desert tribe) are rather numerous, as also Resedacece; but the most prominent feature, is an unusual variety and prevalence of Salsolacex; and of other plants that resemble them in sensible properties.

The river-flats along the Nile were originally a pastoral tract, in all probability abounding in game. As to species, there appears to have been no local provision; but the river opened a path to Northern climates to various antelopes, to the lion, hyæna, ichneumon, genette (Viverra), chameleon, and even to Tropical birds; and these encountered Asiatic animals advancing southward along the banks. There are, however, a few species of birds and quadrupeds that belong properly to the Desert.

\section{THE ANTE-HISTORICAL EGYPTIANS.}

When man entered Egypt, and especially when he began to cultivate and irrigate the soil, game by degrees became rare, and some of the larger kinds disappeared from the valley.

The indigenous plants being unsuitable for the purposes of Agriculture, this art could not have originated on the banks of the Nile; but, together with the objects of cultivation, came from some foreign and distant land.

In artificial conservatories or greenhouses, plants from the extreme North and others from the Tropics, when subjected to the same amount of warmth and moisture, are often found to flourish side by side. Some analogy may be found in the climate of Egypt. It is favourable for the introduction of plants from every quarter; and the soil having been upturned for ages for agricultural purposes, the existing vegetation of the river-flats consists mainly of weeds. 
In most countries, Monumental history commences with relics of a period of barbarism. Such relics are not found in Egypt; but it would seem, that the first colonists who settled on the Lower Nile, were already far advanced in civilization.

\section{EGYPT DURING THE BUILDING OF THE PYRAMIDS.}

According to Diodorus and Clemens Alexandrinus, the Books of Thoth were composed before the time of Menes, the first king of Egypt. This would make Literature, and perhaps the art of writing, anterior to all known monumental history.-On the portion of a mummy-case found at Sakhara by Gliddon (and now in Washington), the animals forming the hieroglyphic characters are painted, not conventionally as in Lepsius Pl. 19 to 22, but according to the colours of life; a circumstance indicating the very commencement of the art of writing.

It seems a natural suggestion, that Idolatry may have had its origin in hieroglyphic writing. However this may be, the Mythological system of the Egyptians was evidently complete at the commencement of their Monumental history.-Gods are figured apart from hieroglyphic writing under the Fourth Dynasty; but such representations continue rare until the time of the Sixth Dynasty.

The hieroglyphic character of the cobra occurs on the Washington mummy-case; and the species, as appears from the coloured figure, is the indigenous C. haje.-On monuments of the Third and later dynasties, the cobra is found to be connected with the mythology (as at the present day in Hindostan); and from the time of the Sixth Dynasty (see Lepsius II. Pl. 115), is also the distinguishing mark of kings.

The hieroglyphic character of the feather, occurs on the Washington mummy-case; exemplifying the general rule, That birds and parts of birds represent vowel and such other sounds as are pronounced without the aid of lips.* The highly finished paintings on this mummy-case, enable us to identify the birds selected for hieroglyphic writing : thus, the owl, is the barn owl (Strix flammea); one of the small birds, is the sparrow (Fringilla domestica); and the young Gallinaceous bird, is the chick of the red-legged partridge (Perdix).

* The seeming exception of the owl for the letter " $\mathrm{m}$," may be explained by the concealed " $m$," or the sound uttered with the lips closed. And this harmonizes with the Greek adoption of the owl for the "bird of wisdom." 
Checkered Nubian baskets are figured on the Washington mummycase.-The wooden Nubian neck-pillow is figured under the Third Dynasty (Lepsius II. Pl. 4); and Nubians themselves, as early, at least, as the Fourth (Lepsius II. Pl. 19). Nubians are also figured at Benihassan under the Twelfth Dynasty (Champollion Pl. 395).

The hieroglyphic sign of the flag-shaped fan occurs on the Washington mummy-case; and at the present day, these fans are made of the leaves of the Doum palm (Hyphrne crinita).-The tree is planted at regular intervals in a garden plan of the time of the Seventeenth or Eighteenth Dynasty (Champollion-Figeac Pl. 55).

The Washington mummy-case is composed of layers of linen.White garments are figured under the Third and Fourth Dynasties (Lepsius II. Pl. 4 and 19); and on all the subsequent monuments, form a distinguishing mark of the Egyptians. The process of spinning and weaving is represented under the Twelfth Dynasty at Benihassan. The flax (Linum usitatissimum) is properly a northern plant; but I found it cultivated throughout the Arab countries to the Dekkan inclusive.

The Washington mummy-case is coated with chunam, or fine, smooth plaster; a material which has been in common use in Egypt throughout all monumental history.

According to Manetho, Menes led an army beyond the limits of Egypt, and became renowned.-Wilkinson states (Thebes and Egypt, p. 341), that the canal Bahr Yusef is sometimes called "El Menhi or' Menhee," apparently from Menes. If the derivation is correct, this will form a remarkable instance of permanence in a name. Compare Herodotus ii. 99.

According to Manetho, Athothis, the second king of Egypt, was of the Medical Profession, and wrote on Anatomy.-Clemens Alexandrinus states, that six of the Sacred Books of the Egyptians treated of Medicine; and Herodotus speaks of the skill and high reputation of the Egyptian physicians.

As the art of medicine was practised, it seems probable, that the traffic in drugs was also in existence.-Egypt has always been the centre of this traffic; and Homer, the earliest Greek writer, pointedly alludes to "the drugs of Egypt."

The traffic in perfumes and valuable gums would naturally be united with that in drugs.-Direct evidence of its existence under the 
Eleventh Dynasty, was found in the lining of the coffin described by Birch.*

The traffic in gems or precious stones, procured in distant lands, was probably also in existence; though I do not know of any direct evidence of the fact.-Garnets and cornelian, according to Champollion-Figeac (Egypte Ancienne, p. 208), are figured in the Tribute processions of the Eighteenth Dynasty: and a variety of precious stones are mentioned in the Hebrew Scriptures.

In all probability, gold was also known.-Birch speaks of ornamental gilding on the above-mentioned coffin of the time of the Eleventh Dynasty; and according to Rosselini, the hieroglyphic name of "nkbt," or gold-washing, occurs on monuments as old or older than the Twelfth Dynasty.

Manetho further states, that Athothis constructed a palace at Memphis; and that Ouenephes, the fourth king of Egypt, built pyramids.-In after times, this palace and these pyramids may have been the earliest monuments known to the Egyptians themselves.

Some of the pyramids built of adobes or sun-dried brick may be among the most ancient.-The one identified, belongs to the time of the Twelfth Dynasty.

Wooden beams are said to enter into the construction of these pyramids ; and an examination of the kinds of timber might decide the question, as to the presence of navigation upon the Mediterranean.Trees are figured under the Third Dynasty; and river-barges, propelled by numerous oars and larger than any now used on the Nile, under the Fifth; but the material for their construction may have been derived from cultivated groves.

According to Manetho, Sesorthus, the second king of the Third Dynasty, erected the earliest buildings of hewn stone. A knowledge of copper is implied: and abandoned copper mines, that were worked as early, at least, as the Fourth Dynasty, have been discovered at Wadi Maghara, in the Sinai Peninsula.

Lepsius found the signs of the seasons and their months upon the stones of the great pyramid at Daschur; showing, that a Calendar was in use during the Third Dynasty. Lepsius also states, that the divi-

\footnotetext{
* Letter on mummies: in Gliddon's Otia Egyptiaca. London, 1849.
} 
sion of the day into hours, minutes, and $60 \times 60$ parts of a minute, was known at an early period to the Egyptians.

The name and portrait of King Senefru of the Third Dynasty, have been found at Wadi Maghara, in a tablet recording a successful military campaign against a long-bearded nation belonging to the White race (Lepsius II. Pl. 2). A tomb constructed during his reign has been found by Lepsius, between Abusir and Sakhara.

The hieroglyphic sign of the guitar occurs in the name of King Senefru; showing, that music was cultivated.-Harpers are figured under the Fourth Dynasty; and at Benihassan under the Twelfth Dynasty, musical instruments are in the hands of foreigners.

Numerals occur on the walls of the above tomb (Lepsius II. Pl. 3); evidence of a knowledge of geometry is found in the construction of the pyramids; and there are reasons for supposing, that nearly all the leading truths in mathematical science had been discovered. Herodotus (who lived before the time of Euclid) held the opinion (ii. 109), that the Greeks obtained their knowledge of geometry from Egypt.

The feather of the ostrich (Struthio) is figured in the above tomb (Lepsius II. Pl. 3); showing, that the traffic in the feathers and eggs of this bird was in existence.-The ostrich is figured at Benihassan under the Twelfth Dynasty; and also, clusters of the feathers and eggs, similar to those carried in later times in the Tribute processions of the Eighteenth Dynasty.

The young shoot of the date palm (Phoenix dactylifera), is also figured. This is clearly a tropical plant; and its introduction into Northern Africa and Palestine must have produced a marked change in the aspect of the country, and some difference also in the habits of the people. In hieroglyphic writing, the date palm is devoted to chronological subjects; advantage having been taken of the circumstance, that the tree lives several centuries, and annually produces a ring of leaves. This original selection seems also to be the source of the remarkable etymological interferences in regard to the name of this tree, in all European languages.-Separate figures of the date palm occur at Benihassan.

The $i b i$ is also figured in this tomb (Lepsius II. Pl. 5). This bird appears to have been always associated with the inventor of the art of writing, or author of the Books of Thoth. The ibis is sometimes figured separately; but usually rests on an artificial perch, or standard.

The animal selected as emblematic of a priest, is usually considered 
to be the jackal; but except in the superior height, the figures agree better with the fox (Vulpes).- - However this may be, here would seem to be the source of the legendary accounts of the cunning of the fox, which have come down to the present day.

Animal sacrifices are represented in the same tomb (Lepsius II. Pl. 3) ; and the head of the ory $x$ is included among the offerings. This species of antelope appears to have been regularly domesticated.And under the Fourth and Fifth Dynasties, is often represented as kept in herds.

The head and neck of a large undetermined species of crane (Grus) is also figured among the offerings (Lepsius II. Pl. 3). This bird appears to have been likewise domesticated.-And on monuments of the Fourth, Fifth, and Twelfth Dynasties, is repeatedly represented as kept in flocks. Single figures occur as late as the Eighteenth Dynasty.

The ibex, or capricorn, is figured in the same tomb (Lepsius II. Pl. 6).-The capricorn is of frequent occurrence on the subsequent monuments; but is always represented single, and is perhaps to be regarded as kept in captivity, rather than fairly domesticated.

The hodyehog (Erinaceus auritus), is figured in the same tomb (Lepsius II. Pl. 3).--The hedgehog is frequently carried in cages on the subsequent monuments, and may have been regarded as a sacred animal: but I met with none of these representations that were later than the Twelfth Dynasty.

The domestic goose is figured in the same tomb (Lepsius II. Pl. 6). -And on all the subsequent monuments.

The dog is figured in the same tomb (Lepsius II. Pl. 3); having the tail curling, but the muzzle pointed, like that of the jackal.Numerous varieties of the dog are figured at Benihassan under the Twelfth Dynasty; and among them, the greyhound, employed as in modern times for its superior swiftness in the chase: a kind of sport, moreover, said to be well known in Nubia.

The sheep is figured in the same tomb (Lepsius II. Pl. 6); a remarkable variety with spreading horns, which appears soon to have become extinct.-Curved horns make their first appearance at Benihassan, under the Twelfth Dynasty: but the original peculiar head was continued in later times in the mythology and hieroglyphic writing.

The bullock is represented in the same tomb (Lepsius II. Pl. 3).- 
A long-horned variety, which occurs on the monuments as late as the Twelfth Dynasty. A hornless variety is figured under the Fourth Dynasty (Lepsius II. Pl. 9 and 22) : and at Benihassan, the bullock is represented in the. state of secondary wildness; parti-coloured individuals being associated with other game in the hunting scenes.

The donkey is figured in the same tomb (Lepsius II. Pl. 5).-Droves of donkeys are figured under the Fourth Dynasty; and under the Fifth, the animal is caparisoned as a beast of burden.

A figure in the same tomb (Lepsius II. Pl. 5), is perhaps intended for the pig.-I found no figure of the pig at Benihassan, nor on any monument prior to the time of the Seventeenth Dynasty. In a tomb at $\mathrm{El} \mathrm{Kab,} \mathrm{a} \mathrm{drove} \mathrm{is} \mathrm{made} \mathrm{to} \mathrm{subserve} \mathrm{agricultural} \mathrm{purposes} \mathrm{in} \mathrm{the}$ peculiar manner described by Herodotus ii. 14; while goats are thus employed on the anterior monuments.

Various kinds of vases are figured in the same tomb (Lepsius II. Pl. 5); evidently of earthenware or pottery.-The details of the art of making pottery are represented at Benihassan, under the Twelfth Dynasty.

The hieroglyphic sign of the branch of a tree for rowing, occurs in the same tomb (Lepsius II. Pl. 5); and indicates, that rafts of earthen jars were floated down the Nile, in the same manner as at the present day.-This use of branches for rowing, is supposed to be the origin of the Latin word "ramus."

The name of King Schafra, of the Fourth Dynasty, has been found in tombs constructed during his reign at Gizeh. He is usually considered to be the builder of the Middle Pyramid at this place; but the point is not definitively settled.

Herds of the domestic goat are figured in these tombs (Lepsius II. Pl. 9) ; and the variety or breed, presents nothing unusual in its aspect.-Representations of the goat are of frequent occurrence on the subsequent monuments.

A priest clad in a leopard skin is figured in one of the same tombs (Lepsius II. Pl. 9); and similar representations occur at a somewhat later date (Pl. 21). The skins were doubtless brought from a distance.-Indeed, leopard skins still form an article of traffic at Mocha.

The dog-faced ape (Cynocephalus) is figured in one of these tombs (Lepsius II. Pl. 13); doubtless brought down the Nile from Abyssinia or from Central Africa.-The cynocephalus is again figured at Benihassan; and from the time of the Seventeenth Dynasty, is found to be 
connected with the Mythology; as the monkey is in Hindostan at the present day.

A species of monkey. (Cercopithecus) is figured in the same tombs; and also at a somewhat later date (Lepsius II. Pl. 13 and 36).-Other kinds of monkeys are represented at Benihassan, but apparently, all derived from the Upper Nile. At no period, do I find these animals connected with the Egyptian Mythology.

The hyona is represented in the same tombs (Lepsius II. Pl. 10); and apparently in a semi-reclaimed state.

The habits of the Early Egyptians appear to have been in great part pastoral; but agricultural occupations are also represented in these tombs; together with the grape (Vitis), and the art of making wine.The details of this art are again figured on monuments of the time of the Seventeenth and Eighteenth Dynasties.

Clusters apparently of figs (Ficus carica) are included among the offerings of fruits and vegetables (Lepsius II. Pl. 10).-The fig tree is distinctly represented at Benihassan, and on monuments of the time of the Seventeenth and Eighteenth Dynasties.

Crops of grain and the process of reaping, are represented in the same tombs (Lepsius II. Pl. 9) : perhaps rye, or spelt, but probably wheat (Triticum hybernum).-The ambiguity continues on the subsequent monuments : but wheat is mentioned under its current Egyptian name in Genesis xviii. 6, and Numbers v. 15; and under its current Greek name by Homer, Odys. ix. 191, and xxiv. 208.

The paper-rush (Papyrus) is figured in the same tombs; together with the process of writing, and rolls or books (Lepsius II. Pl. 9 and 12). - The plant is frequently represented on the subsequent monuments : but its cultivation having been neglected in modern times, it has nearly, if not altogether, disappeared from Egypt. The latter circumstance, among others, indicates a foreign origin.

The sacred water-lity or lotus (Nymphæa) occurs among the offerings in the same tombs (Lepsius II. PI. 10).-The species is probably the N. cærulea; for though I met with no flowers painted blue prior to the Twentieth Dynasty, the margin of the leaves, even in highly finished representations, is invariably entire. The N. cærulea is perhaps indigenous; or if floated down the Nile, remains to be discovered in Central Africa. The blue Nymphra of East Africa, seen by myself at Zanzibar, has dentate leaves. I met with dried flowers of a 
third blue Nymphæa in a drug shop at Mocha; probably the N. stellata of Hindostan.

A figure among the offerings (Lepsius II. Pl. 14, 36 and 68) seems intended for the root of the Typha; which is said to be esculent.Aeschylus (Ag. 1521) speaks of beds of rushes or rush-mats; made, according to Aristophanes (Acharn. 874, and Lys. 721) and the scholiast, of "psiathos ;" or, as would appear from the current Greek name, of the leaves of $\mathrm{T}$. latifolia. This species is unknown in Egypt; but the T. angustifolia was seen by Delile, growing spontaneously at Rosetta.

Further in regard to the habits of the Early Egyptians: Persons are represented in these tombs, employed in curing fish: and the mode of carrying burdens is, by the balance-beam on the shoulder; as among the Polynesians at the present day.

A portrait of King Chufu, or Cheops, of the Fourth Dynasty, has been found at Wadi Maghara; in a tablet recording the military conquest of a long-bearded nation belonging to the White Race (Lepsius II. Pl. 2). His name occurs also at Gizeh, in the Great Pyramid, admitted to be his tomb; and in small tombs in the vicinity, apparently constructed during his reign,

The arrows of the Nubian archers, figured in one of these small tombs (Lepsius II. Pl. 19), may have been from the reed (Arundo donax).-On some early monuments, the Nubian and Egyptian arrows are marked at regular intervals, like joints (Rosselini II. Pl. 117 and 118) ; and the arrows of the foreigners at Benihassan, were doubtless from the reed. In the time of Pliny, the reed appears to have been extensively cultivated in Egypt; and its rarity at the present day, is partly to be attributed to the change in the mode of warfare.

During the reign of Chufu, hieroglyphic writing was used generally, and for common purposes; as appears from quarry-marks in red chalk still remaining on interior stones of the Great Pyramid.

The chambers and internal passages of the Great Pyramid are in part constructed of sienite; floated down the Nile from the First Cataract.

The base of the Great Pyramid has been found to conform to an exact meridian line: and other evidence of the advanced state of astronomical science has been discovered.-Tables of the Constellations were found by Champollion in tombs of the time of the Twentieth Dynasty. 
An inscription having reference to the construction of the Great Pyramid, as interpreted to Herodotus (ii. 125), contained notices of the two following plants: The "krommya" or onion (Allium cepa).Figured under the Seventeenth or Eighteenth Dynasty; and mentioned under its current Egyptian name in Numbers xi. 5, and under its current Greek name by Homer.

And the "skoroda" or garlic (Allium sativum). The interpreters, however, in conversing with Herodotus, may have had in view the plant figured in the neighbouring tombs, to be noticed presently.The garlic is mentioned by Homer; but at the present day, is very sparingly cultivated in Egypt, and even, according to Hasselquist, forms an article of importation.

The name of King Menkera, of the Fourth Dynasty, occurs on the wooden coffin discovered in the Third Pyramid at Gizeh. This pyramid is therefore the tomb of King Menkera; and though the smallest of the three, is built entirely of sienite from the First Cataract, agreeably to the statement of Herodotus ii. 134.-The memory of King Menkera appears to have been much venerated by the Egyptians; and his name occurs in sacred writings and prayers composed centuries after his decease.

The inscription on this wooden coffin, has been ascertained by Birch to be an extract from the Osiris-myth; and the high antiquity of this sacred drama is thus demonstrated. The material of the coffin, described as "a kind of cedar," may have been imported; for the Coniferous trees at present cultivated in Egypt, hardly afford timber of sufficient size.

In a tomb at Gizeh, apparently constructed during the reign of Menkera, are figures of a species of Allium (Lepsius II. Pl. 36) ; perhaps the garlic, or the onion, but agreeing better with the shallot (Allium Ascalonicum).-According to Zalikoglous' account of the Greek usage,* the "gethyon" of Theophrastus vii. 4, is the shallot. This plant was seen in Greece by Bory de St. Vincent; and in Egypt, by Alpinus.

Men probably of the Negro Race are represented in the same tomb (Lepsius II. Pl. 36); at least, if we may judge from their wearing the three-lobed emblem. - This emblem occurs at Benihassan as a black writing style (Champollion Pl. 361); but in other instances, on monu-

* Modern Greek Lexicon by Zalikoglous. Venice, A.D. 1815. 
ments of the Seventeenth and Eighteenth Dynasties, appears to be a plant, not unlike the Iris : and analogy may also be remarked in the color of the Iris flower. The Iris sisyrinchium, according to Forskal and Delile, is indigenous in Lower Egypt.

On the monuments of the Fourth and Fifth Dynasties, Lepsius found the cubit to be " 524 millimetres" in length; and the standard weights and measures, to be the same with those used in later times by the Babylonians and Persians.

The name of King Useskef, of the Fifth Dynasty, has been found in tombs at Gizeh (Lepsius II. Pl. 40); and also in the beautiful tomb at Sakhara, which appears to have been constructed during his reign.

A portrait of King Sahura, of the Fifth Dynasty, has been found at Wadi Maghara, in a tablet recording the military conquest of a nation belonging to the White Race (Forty Days in the Desert, Pl. 12); his narne occurs also on the stones of the North Pyramid at Abusir, which is thus ascertained to be his tomb (see Lepsius II. Pl. 39).

The name of King Nefrukera, of the Fifth Dynasty, has been found at Sakhara and Gizeh, in tombs apparently constructed during his reign.

Crops of barley (Hordeum), distinguished by the inferior height and the thicker and beardless spikes, are figured in one of these tombs (Lepsius II. Pl. 47. Compare also Champollion, Pl. 417).-Barley is again figured on monuments of the Sixth and Seventeenth Dynasties; and is mentioned under its current Egyptian name in the Hebrew Scriptures; and under its current Greek name, by Homer.

The porcupine (Hystrix) is figured in the same tomb (Lepsius II. Pl. 46). The living specimen may have been imported into Egypt from the East.

The name of King Ransesr, of the Fifth Dynasty, has been found on the stones of the Middle Pyramid at Abusir; which is thus ascertained to be his tomb. His name occurs also at Wadi Maghara, and in small tombs at Gizeh, apparently constructed during his reign (Lepsius II. Pl. 55, 59, and 152).

The name of King Tetkera, of the Fifth Dynasty, has been found at Sakhara, in a tomb apparently constructed during his reign (Lepsius II. Pl. 63).

The name of King Assa, of the Fifth Dynasty, has been found at Gizeh, in tombs apparently constructed during his reign (Lepsius II. Pl. 67 and 74). A papyrus written by one of his officers (and dis- 
covered at Thebes by Prisse), is described by De Rougé, as having the letters slightly cursive; thus making some approach to hieratic writing.

Many of the above tombs, with others at Gizeh not later than the Fifth Dynasty, were pointed out to me by Mr. Bonomi; and in the original paintings, I met with figures, in color, shape, and relative size, corresponding with the water-melon (Citrullus).-Similar figures occur on monuments of the Seventeenth and Eighteenth Dynasties; and the water-melon, under its current Egyptian name, is mentioned in the Hebrew Scriptures (Numbers xi. 5).

Also, figures of a long, green, slightly curved fruit, perhaps intended for the hairy cucumber (Cucumis chate).-Similar figures occur on the subsequent monuments. This species of cucumber is cylindrical and devoid of papillæ, and if I understood aright, is called "gutteh" in Lower Egypt: it seems therefore to be the "khth" of Exodus ix. 32.

Figures perhaps intended for the fruit of the pomegranate (Punica granatum); being apparently distinct from the small earthen vases of similar shape.-The pomegranate tree, with its fruit, is figured on monuments of the Seventeenth Dynasty (Rosselini II. Pl. 68); and is mentioned under its current Egyptian name in Numbers xx. 5, Deuteronomy viii. 8, and Solomon's Song iv. 3 ; and under its current Greek name, by Homer, Odys. vii. 115.

And in a single instance, figures, possibly intended for the cabbage, but more resembling heads of the artichoke (Cynara scolymus).-The "kinara" of Sophocles, Ptolemy Euergetes, and Athenæus, is considered to be the artichoke; and this plant is abundantly cultivated in Egypt at the present day.

The name of King Atai, or Othoes, of the Sixth Dynasty, has been found at Hamamat, on the Kosser road (Lepsius II. Pl. 115); but apparently, not on a contemporaneous monument.

The name of King Pepi, or Phiops, of the Sixth Dynasty, has been found at Wadi Maghara, Sauiet el Meitin, Schech Said, Hamamat (Lepsius II. Pl. 110, 112, 115, and 116), and even as far up the Nile as Napata near in Dongola; together with the date of the sixteenth year of his reign.

The name of King Mentuatep, of the Sixth Dynasty, has been found at Hamamat (Lepsius II. 149), and in other localities; together with the date of the second year of his reign.

Of the domestic animals and plants thus far mentioned, most of them will be found to be of Northern origin. Of the plants, however, 
seven are decidedly Tropical; the doum palm, date palm, papyrus, fig, pomegranate, hairy cucumber, and water-melon : some of these may have come from Abyssinia, or from the mountains of Yemen; but the doum palm being excepted, the remainder are sufficiently hardy to bear transportation by an extra-tropical route. I have met with no evidence of the existence, at this early period, of a Southern route of communication with India, by the way of Meroe and by sea.

The name of King Nefrukera II., of perhaps the Seventh Dynasty, has been found at Wadi Maghara, and at Kauamat (Lepsius II. Pl. 116).

The name of King Merenra, of the same dynasty, has been found at Wadi Maghara, Chenoboskion (Lepsius II. Pl. 113), and in a tablet on the Kosser road. Other kings of the dynasty of the Nefrukeridæ, are known from the genealogical tablet at Abydos; but their names have not been found on contemporaneous monuments.

The name of King Mentuatep II., or Mentuatep Nebtura, of perhaps the Eighth Dynasty, has been found at Assuan (Lepsius II. Pl. 149) ; but perhaps, not on a contemporaneous monument.

The name of King Nachtenra, apparently of the Ninth or Tenth Dynasty, occurs in the genealogical table of the chamber at Karnak; but has not been found on contemporaneous monuments.

Tombs of kings of the Eleventh Dynasty have been discovered at Gurna, in the northwest quarter of Thebes; and in one of them, the coffin of King Nentef II. was procured. This coffin is now in the British Museum; and, on examining the lining, Birch met with inscriptions in hieratic writing. This is properly cursive hieroglyphic writing: for it bears the same relation to hieroglyphics, as handwriting does to printed letters.

Birch found ivory employed in the ornamental work on the same coffin (procured in all probability from the African elephant, on the Upper Nile) :

Also, obsidian (brought probably from some distant locality, there being no volcanic district immediately around Egypt) :

And bronze.-The art of forming this compound metal, has by other means been traced beyond the historical records of Greece.* Direct evidence has been obtained that the traffic in tin was carried on in the days of Homer; plates of this metal having been recently

* See Smith's Dictionary of Greek and Roman Antiquities. 
unrolled in a mummy at London, and in another at Boston; the latter, belonging to the time of the Twenty-Second Dynasty.

The ovals of three other kings, bearing the name of Nentef, have been found in the same series of tombs at Gurna.

\section{THE HYKSOS PERIOD.}

The name of Amenemha, the first king of the Twelfth Dynasty, has been found on a stela (now in the Museum at Paris); together with the date of the eighth year of his reign.

The name of Sesurtesen, the second king of the Twelfth Dynasty, has been found on monuments throughout Egypt and Nubia; together with various dates, the latest of which is in the forty-third year of his reign. He appears to have first erected obelisks; thereby introducing a marked change in monumental history.-Obelisks bear inscriptions dedicating an adjoining temple. They were placed only in the royal or dynastic cities; the same that in the Egyptian Tables of Chronology, seem to be designated by their tutelar deities; as Memphis, by Pthah or Vulcan; Heliopolis, by Ra; Elephantine, by Num or Agathodæmon; Crocodilopolis, by Seb or Saturn; Abydos, by Osiris ; Tanis, by Typhon; Thebes, perhaps by Horus; and it is known, that Sais once possessed obelisks.

Obelisks erected by Sesurtesen, still remain at Crocodilopolis (in the Faium) and at Heliopolis. The one at Heliopolis is not of sienite, but of granite proper; and the place from which it was transported, remains unascertained. A fragment of a colossal statue of Sesurtesen, in "black granite," is now in the Museum at Berlin.

The most ancient temple hitherto discovered, is situated in Nubia, at the Second Cataract of the Nile, and was built by Sesurtesen. His portrait has been discovered near the sanctuary, in a stela, or stone slab, recording the conquest of Nubian and Lybian tribes. He also founded the temple at Karnak, in Thebes.

The tomb of one of his military chieftains, in the series at Benihassan, is conspicuous by the columns at the entrance.-The same supposed to have furnished the Greeks with the idea of the Doric architecture.

The name of Amenemha II., the third king of the Twelfth Dynasty, has been found on the monuments; together with various dates, the latest of which is in the thirty-fifth year of his reign.

The remaining tombs at Benihassan were also excavated during the 
Twelfth Dynasty. The paintings on the walls represent a vast variety of subjects: including, most unexpectedly, the greater part of the arts and trades practised among civilized nations at the present day; also, birds, quadrupeds, fishes, and insects, amounting to an extended treatise on zoology, well deserving the attention of naturalists. The date accompanying these representations, has been astronomically determined by Biot at about B. C. $2200^{*}$ (Champollion-Figeac, Egyp. Anc.); and Lepsius' chronological computation corresponds.

The tomb dated in the reign of King Sesurtesen II., contains the earliest record hitherto discovered, of the introduction of a body of foreigners into Egypt. The strangers belong to the White Race; are termed "captives," a point of agreement with the Hyksos of Manetho (Josephus, C. Apion. i. 14); use the javelin; and, unlike the Egyptians, wear variegated garments.

In an adjoining tomb (Champollion, Pl. 396), a kindred nation, wearing only the cincture, and therefore inhabiting a warm climate, is represented fighting the Egyptians. The siege of a fortified place is also represented. And Lepsius (Briefe aus Aegyp. p. 367) observed one of these foreigners in the state of servitude among the Egyptians.-In a royal tomb of the Nineteenth Dynasty, the same foreign nation wears the Bedouin fillet.

The scarlet portion of the variegated garments may have been dyed with kermes (Coccus ilicis); an insect production, obtained around the northern shores of the Mediterranean.-The use of kermes is mentioned in Genesis xxxviii. 28; Exodus xxv. 4 ; Leviticus xiv. 4 ; Proverbs xxxi. 21; Isaiah i.18; and also by Ctesias, Theophrastus, and Pliny.

The domestic and useful animals and plants of the anterior monuments, again make their appearance at Benihassan; figured too in the same peculiar varieties; and, notwithstanding the lapse of time, additional kinds are surprisingly few. I met with only the four following:

Among the various species of ducks, a flock possibly of the domesticated bird.-Ducks, apparently, are swimming in artificial pools in a garden-plan of the time of the Seventeenth or Eighteenth Dynasty (Rosselini, II. Pl. 69); and tame ducks are mentioned by Aristophanes, Plautus, and Varro.

Perhaps, the Indian bullock (Rosselini, Monum. Civil. Pl. 20).-

* The astronomical observations procured at Babylon, and sent by Calisthenes to Aristotle, went back to B. C. 2233 (Clinton, Fast. Hellen. I. pp. 281 and 368). The Chinese are said to possess records of equal antiquity. 
The same variety is figured on monuments of the Nineteenth Dynasty; but always, I believe, as inhabiting the enemy's country.

Albino rabbits (Lepus cuniculus), carried in cages, and perhaps regarded as sacred; (distinguished by the shorter ears from the hare, which is separately figured in the hunting scenes).-I met with no figures of the rabbit elsewhere on the monuments ; and in the time of Athenæus (ix. 63), the animal was unknown in Egypt. The rabbit is mentioned by Polybius, Varro, and Poseidonius; but it seems to belong properly to the West; and according to Leo Africanus, is indigenous in Mauritania.

And the cheeta, or hunting leopard (Felis jubata); led by a cord, and doubtless brought from Nubia.-The cheeta is again figured in the tribute-processions of the Eighteenth and Nineteenth Dynasties.

As to the stag (Cervus elaphus) figured in the hunting scenes; some of these may include the game of Northern climates; but Wilkinson was assured, that stags are sometimes seen in the vicinity of the Natron Lakes (Anc. Egypt. III. p. 23). The tiger (Lepsius, II. Pl. 131), was probably from the shores of the Caspian.

The Nubian clubs figured at Benihassan (Champollion, Pl. 395), were probably made of the material employed at the present day; said by my Dongola attendant to be "selem" wood. From Forskal's account of the Yemen usage, the "selem" would appear to be a species of Acacia, and perhaps the A. Nilotica.

An Acacia tree is separately figured at Benihassan (Champollion, Pl. 353), probably the last named A. Nilotica, planted for the use of its timber in constructing river-barges. This is mentioned by Herodotus; and is practised at the present day. I found the A. Nilotica, the most common tree around villages situated upon the margin of the Desert.

The Cucurbitaceous plant figured at Benihassan (Champollion, Pl. 357 ), growing over a frame, and having oblong fruit and deeply lobed leaves, is perhaps the balsam-apple (Momordica balsamina).-The balsam-apple seems to be mentioned by Avicenna and Abd Allatif; and was seen by Forskal and Delile in gardens at Cairo.

The name of Sesurtesen III., the fifth king of the Twelfth Dynasty, has been found in the sanctuary of the temple at Semneh, above the Second Cataract; also, in other parts of Nubia, and on the Kosser road; together with the date of the sixth year of his reign. The adobe pyramid at Daschur, appears to be his tomb. 
The name of Amenemha III. or Amenemha Moeris, the sixth king of the Twelfth Dynasty, has been found in the pyramid near the Labyrinth; the latest, apparently, of the Egyptian pyramids, "sixtynine in number," and each of them constructed for a king's tomb. The name of Amenemha III. has also been found at Wadi Maghara : and he is considered to be the builder of the Labyrinth.

The word "hbni," meaning ebony, has been traced by Lepsius in hieroglyphic writing as far back as the Twelfth Dynasty. The wood was doubtless brought down the Nile; but may nevertheless have been derived, by the direct interior route, from the island of Madagascar.-Sticks of ebony are carried by Southern delegates in the tribute-processions of the Eighteenth Dynasty; and Herodotus speaks of ebony being brought down the Nile.

The Egyptian Ritual, or Book of the Dead (the most voluminous work in hieroglyphic writing hitherto discovered), has been traced by Birch, by means of extracts on coffins, as far back as the Twelfth Dynasty.

The name of Amenemha IV., the seventh and last king of the Twelfth Dynasty, has been found on a stela, and on other movable articles now in the museums of Europe.

The name of Sebeknefrura, the first king of the Thirteenth Dynasty, has been found among the ruins of the Labyrinth (Lepsius, II. Pl. 140).

The name of King Sebekatep II. of the Thirteenth Dynasty, has been found on a large stela, now in Paris.

The name of King Nefruatep, of the Thirteenth Dynasty, has been found on a statue, now in the Museum at Bologna.

The name of King Sebekatep III. of the Thirteenth Dynasty, has been found among the ruins at Abydos. A colossal statue of this king, is now in the Museum at Paris.

The name of King Sebekatep IV. of the Thirteenth Dynasty, has been found among the ruins at Abydos.

The name of King Sebekatep V. of the Thirteenth Dynasty, has been found on a granite altar, procured at Abydos.

Birch found "beer" mentioned on mummy-cases of the time of the Thirteenth Dynasty. It was probably the Egyptian beverage called booza; which is manufactured from barley, as described by Herodotus ii. 77.-Alpinus states, that "farina loliacea" is used in making booza; 
and in all probability, the practice is not of recent origin. The Lolium perenne and $L$. temulentum were seen by Forskal and Delile, growing around the towns of Lower Egypt.

The name of King Rakamai, of the Thirteenth Dynasty, has been found in one of the excavated chambers or tombs at Siut (Lepsius, II. Pl. 150). The soldiers figured in this tomb (Champollion, Pl. 349) are all on foot, resemble those at Benihassan, and are armed with similar weapons.

The name of King Sebekemsaf, of the Thirteenth Dynasty, has been found at Konosso, and at Hamamat on the Kosser road (Lepsius, II. Pl. 151) : a coffin dated in his reign, is now in the Museum at Leyden.

According to Birch, Sepulchral vases having the form of the four Genii of the dead, were first used during the Thirteenth Dynasty : and the usual formula relating to the doctrine of Transmigration, is inscribed on the scarabæus of King Sebekemsaf, now in the Museum at London.

About this time, Lower Egypt, in some unexpected manner, fell into the hands of the Hyksos. According to Manetho, These people came from the East, were of obscure or ignoble origin, and obtained possession of the country without fighting. Manetho (or perhaps Josephus) alludes to an opinion held by some, that the Hyksos were Arabs : and the event is possibly connected with the introduction and substitution of the Arabic as the spoken language of Egypt.

After establishing their authority, The Hyksos proceeded to maltreat the native population; killing some, and reducing the wives and children of others to slavery; also, demolishing the temples (a circumstance indicating a different religion); and at length, they made one of their number king. Salatis, the first Hyksos king, set up military posts, and collected tribute or taxes throughout Upper and Lower Egypt: and Manetho further states, That Salatis directed especial attention to the northeastern frontier, and built there a stronghold or fortified city, from a jealousy of the rising power of the Assyrians.

A triangular game of military conquest has been going on between Egypt, Asia Minor, and the East, perhaps from the commencement of monumental history; and still remains unsettled. The relative geographical position will explain, Why the Persians did not move against 
Egypt before obtaining possession of Asia Minor; and, Why Alexander would not move against Persia without first securing Egypt. The very latest invader of Egypt had scarcely established himself at Cairo, before he adopted the Egyptian View, and shaped his measures accordingly (see Thiers, Hist. Revol. Française).

The Hyksos kings were counted as an Egyptian Dynasty, and the names of some of them are given by Manetho; but no building erected by their orders, has been identified. It further appears, that during the rule and oppression of the Hyksos or "Shepherds," the legitimate Egyptian kings maintained their line of succession, and perhaps, in Upper Egypt, some independence.

The name of Sekennen-raken, an Egyptian king, apparently of the Fifteenth or Sixteenth Dynasty, has been found in one of the tombs at El Kab; but not on a contemporaneous monument.

According to Manetho, At the end of five hundred and eleven years, and after protracted wars, the Hyksos were expelled from the greater part of Egypt, and were hemmed up in the before-mentioned stronghold on the Northeastern frontier.

The Turin papyrus ends here, after enumerating some two hundred and fifty successive kings; among whom, Lepsius found sixty-five belonging to the Hyksos Period.-Seeming allusions or traditionary reminiscences of the Hyksos, occur in Genesis xlvi. and xlvii., and in Herodotus ii. 128.

\section{EGYPT UNDER THE PHARAOHS.}

The Egyptian king who recovered his authority, appears to have been Aahmes, the head of the Seventeenth Dynasty. According to Champollion-Figeac, the epitaph of one of his military officers contains an allusion to wars in Lower Egypt; and inscriptions at Massara, dated in the twenty-second year of his reign, record the opening of quarries for the repair of temples at Memphis. A portrait of King Aahmes, has been found on a stela, now in the Museum at Marseilles.

The rearing of temples, is not the only change that now takes place in Monumental History. Figures of gods are no longer rare; but the sculptures teem with manifestations of idolatry and polytheism. Were, however, all other marks wanting, the Pharaonic structures might readily be recognised, 
By the figures of the horse. Sieges and military campaigns (conducted on foot) are occasionally represented on the anterior monuments; but with the acquisition of the horse, a change appears to have taken place in the national character; and the Egyptians became a warlike and conquering people; leaving on their monuments, ample illustration of the so-called "Heroic Ages."

The name of Amenatep, Aminadab or Amenophis, the second king of the Seventeenth Dynasty, has been found on various monuments (some of them, according to Champollion-Figeac, recording foreign wars): his memory was held in veneration in after times; and a statue of this king is now in the Museum at Turin. Amenatep built a portion of the temple at Karnak (De Rougé); and the queen associated with him on the monuments (Lepsius, III. Pl. 1), appears to have been of the Nubian or the proper Ethiopian race.

A box for holding small sepulchral images, dated in this reign, is mentioned by Birch, as the earliest instance hitherto discovered of the custom of depositing these images. They are all inscribed with the same extract from the Ritual.

According to Champollion-Figeac, Tetmes, the third king of the Seventeenth Dynasty, built the most ancient portion of the temple at Medinet Habu; also, a cave-temple at Ibrim, in Nubia ; and a magnificent colossal statue of this king, is now in the Museum at Turin.

Clusters of a red fruit, not unlike that of the lote tree (Zizyphus lotus), are figured in a tomb at El Kab.-This tree is usually considered to be the "loton" celebrated by Homer (Od. ix. 97) : and the modern Egyptians have a traditional assertion, that it bears "the finest of all known fruits."

Crops of a brown-headed grain, pulled while the stems are green, in these respects resembling the millet (Echinochloa Italica), are figured in the same tomb; but the single terminal head, and in a second representation (in a royal tomb of the Nineteenth Dynasty) the superior height, agree better with Pennisetum typhoideum; especially, as the latter plant has its spike always erect, and in some varieties ovoid.-The Pennisetum bears the same Egyptian name as the millet; and hence arises a difficulty in tracing its history. It is, however, distinctly figured by Dodonæus.

Foreigners belonging to the White Race, are represented in the state of servitude in the same tomb.

Tetmes II., the fourth king of the Seventeenth Dynasty, made addi- 
tions to the temple at Medinet $\mathrm{Habu}$; and also erected buildings at Esneh, and at Semneh in Nubia.

The practice of blackening the eyelids with "kohl" (a preparation said to be composed partly of antimony), seems to be figured on the monuments, at least as far back as the Seventeenth Dynasty.-The use of kohl, or eye-paint, is mentioned in 2 Kings ix. 30 ; and among Greek writers, by Ion and by Julius Pollux v. 16, 101.

The plant figured in the Asasif, and on subsequent monuments (Lepsius, III. Pl. 19 and 78), is perhaps, the white variety of the beet (Beta vulgaris).-The current Egyptian name of the beet is "selk;" and in this word, we recognise the "seytlon" or "teytlon" of Melanthius, Aristophanes (Pac. 1008), Eudemus, and Athenæus ii. 57. The beet, under its Latin name, is mentioned by Plautus and Martial.

The incense-burner is figured in the Asasif, and on subsequent monuments (Lepsius, III. Pl. 19, 58, 71, and Champollion-Figeac, Pl. 86).-Frankincense is supposed to be the product of Boswellia thurifera, an indigenous tree of Hindostan. The "lbnh" of Leviticus ii. and xxiv., Numbers v. 15, Isaiah Ix. 6, and Jeremiah vi. 20, may be compared with the "libanos" of Euripedes and Dioscorides, and with "luban," the current Egyptian name of olibanum or frankincense.

According to Birch, the mummy-cases of the time of the Seventeenth Dynasty are usually of sycamore wood (Ficus sycomorus).-The mystical sacred tree (which in some representations is clearly the sycamore) is figured at the commencement of the Eighteenth Dynasty; and also, a tank with trees, apparently sycamores, planted around (Lepsius, III. Pl. 37 and 40).

According to Lepsius, the Hyksos did not quit the Egyptian frontier until the commencement of the reign of Tetmes III. This would place the building of Jerusalem later than B. C. 1550 : for, according to Manetho, Jerusalem was built by the Hyksos; and at the time of its foundation, the Assyrians ruled in Asia.

Tetmes III. thus became the head of the Eighteenth Dynasty. The date of his thirty-fifth year has been discovered; and his long and apparently peaceful reign is remarkable for the vast amount of building. At Thebes, the temple in the Asasif was completed, and additions were made at Kaprnak, and at Medinet Habu: in other parts of Egypt and in Nubia, temples were erected, continued, or coinmenced, at Esneh, El Kab, Edfu, Ombos, Elephantine, Amada, Eguisse, Semneh, Ibrim, and Wadi Halfa: two obelisks of some ninety feet in height, were placed at Karnak ; and other obelisks, in situations from 
which they have been removed (two having been carried to Alexandria, one to Constantinople, and one to Rome): but above all, we are indebted to Tetmes III. for an important historical document, the Genealogical Table of the chamber of Karnak, now in the Museum at Paris.

According to Champollion-Figeac, a manuscript, or papyrus, containing a contract dated in the fifth year of Tetmes III., is now in the Museum at Turin.

In the Procession of foreign nations bearing tribute to Tetmes III., the head and neck of the domestic fowl (Champollion-Figeac, Pl. 61) is brought in the prepared state as a curiosity. The inference is, that the living bird was unknown in Egypt; though in some distant land, in Hindostan or the region beyond, perhaps already the companion of man. The above is the only known figure of the domestic fowl on the Egyptian monuments; and I do not find the bird mentioned in the Hebrew Scriptures, nor in Homer, Hesiod, nor in any writings more ancient than Theognis 862, the Batrachomyomachia, Epicharmus, and Eschylus.

In the same Tribute-procession, the young elephant, being led by men of the White Race, could not have been procured on the Upper Nile; in all probability, it is an Indian elephant, brought by land, by the Nabathean or a more northern route. The accompanying large tusks of the African elephant, may even have been derived from maritime intercourse between India and Equatorial Africa.-The bear led by the corresponding delegates in a later Tribute-procession, also indicates a Northern nation.

The above two instances furnish unequivocal evidence of intercourse with India; not so with the living exotic tree, carried by delegates who do not seem to belong to the White Race. This tree has a checkered receptacle (denoting Nubia and South Arabia), and in foliage resembles the sycamore; and also, the Salvadora Persica.-Pliny and other ancient writers, speak of the "persea" tree having been planted in Egypt by Perseus (a tradition which may have had its origin in this very painting): and the account by Dioscorides of the "persea" and its medicinal use, agrees very well with the description of the Salvadora by Forskal (p. 32). The_Salvadora was seen in Upper Egypt by Delile.

The above exotic tree, notwithstanding the discrepance in the foliage, is by some writers referred to the Cordia myxa. It has also been as- 
serted, that some of the mummy-cases are made of this wood: a point on which I am unprepared to offer an opinion.-Birdlime is said to be procured from the Cordia myxa; and according to some authorities, is mentioned in Amos iii. 5.

Living plants in pots, perhaps the Crocus, are carried by a third set of delegates. These wear the simple cincture, denoting a warm climate; but manifest a taste for the fine arts, and we are again reminded of Asiatic Greeks.-The Crocus is mentioned by Homer, and by Pliny xxi. 17; and several species of this flower are known to be indigenous in Greece.

Strings of beads, apparently for rosaries or prayer-beads, are brought by delegates in this Tribute-procession.

Baskets of a blue pigment resembling indigo, are figured in this Tribute-procession: possibly the "blue earth" known to be procured in mines in the Valley of the Euphrates. The question could probably be settled by a chemical analysis of the ancient Egyptian pigments.

According to Chanpollion-Figeac (Eg. Anc., p. 208), rings of silver are figured in this Tribute-procession.- Silver is mentioned in the Books of Moses, and by Homer; and the mummy recently unrolled at London (of the time of perhaps the Twenty-Fifth Dynasty), "contained a silver plate."

According to Champollion-Figeac, Amenatep II., the second king of the Eighteenth Dynasty, continued the temples at Karnac and in Nubia, and erected new ones at Bigeh and Kalabsheh. His name has been discovered in a cave-temple at Ibrim; also, at Sarbut-el-Khadem, in the Sinai Peninsula: and a colossal statue of this king is now in the Museum at Turin.

Tetmes IV., the third king of the Eighteenth Dynasty, completed the temple at Amada; made additions to those at Wadi Halfa and Thebes; and set up obelisks (one of which is now at Rome). An inscription at Philæ, dated in the seventh year of his reign, records a victory over the Lybians: and a stela, also dated in his reign, was found in front of the Great Sphinx at Gizeh (Lepsius, III. Pl. 68).

Branches of myrtle (Myrtus communis) carried by females, are figured on monuments of about this period (Rosselini, II. 99).--The myrtle is clearly a Tropical plant, introduced into the Mediterranean countries: Pliny speaks of it as a stranger to Italy; mentioning, however, the recorded fact, That a stock was found growing on the site selected 
for the building of Rome. Both Theophrastus and Pliny notice the presence of the myrtle in Egypt: where it is still common in gardens.

The fruit tree figured in one of the tombs at Gurna (Rosselini, II. Pl. 68), is possibly intended for the pear (Pyrus communis).-The pear is noticed by Homer and by Virgil ; and according to Forskal and others, is cultivated in Lower Egypt at the present day.

The tall ornamental tree, figured in garden plans at Gurna (Champollion, Pl. 174, and Rosselini, II. Pl. 68), is possibly intended for the poplar (Populus nigra).-Various ancient writers mention the poplar; and the tree was seen by Forskal and others in the gardens of Lower Egypt.

According to Champollion, Amenatep III., the fourth king of the Eighteenth Dynasty, opened the quarries at Silsilis; and from this time, sandstone became the favourite building material. The two colossi so conspicious, still sitting on the plain at Thebes, are statues of this king; but the immense temple once behind them, has been destroyed to the foundations, which are now traced with difficulty. Amenatep III. built the great temple at Luxor; and smaller temples at Elephantine, and at Soleb in Upper Nubia ; he also set up obelisks; carried on wars in foreign countries; and the names of some sixty tribes conquered by him, are recorded on the monuments, together with the date of the thirty-sixth year of his reign.

The flower of the Nelumbium does not occur on the Egyptian monuments; but there is less certainty in regard to the fruit. I repeatedly met with figures resembling this fruit; as, for instance, the emblem designating Asiatic prisoners. - Herodotus distinctly describes the Nelumbium, and saw the plant growing in Egypt; where it appears afterwards to have become extinct, and to have been only recently re-introduced.

According to Lepsius, Amenatep IV., the fifth king of the Eighteenth Dynasty, introduced a foreign religion into Egypt: a portrait of this king occurs in the sculptures at Amarna.

Her, or Horus, the sixth king of the Eighteenth Dynasty, re-established the ancient religion. He also made additions to the temples at Luxor and in the Asasif; constructed cave-temples at Gebel Addah in Nubia, and at Silsilis; and the date of the seventh year of his reign has been found on the monuments. Champollion-Figeac describes some finely executed statues of this king, now in the Museum at Turin. 
Birch met with a mummy possibly belonging to this reign; and ascertained, that the dead were provided with funeral papyri (doubtless, as in later times, inscribed with portions of the Egyptian Ritual). Bodies of this early period are rare; but I saw at Thebes an unopened inner mummy-case, highly finished, and in the style of workmanship of the Eighteenth and Nineteenth Dynasties.

De Rougé met with a sort of secret or cipher writing upon two stela of the time of the "Eighteenth Dynasty:" and Champollion remarked something of the same kind in the royal tombs at Bab-el-Meluk.The art of writing in cipher, or in occult eharaeters, is known to have been long practised in the East; and seems to be mentioned by Homer, Il. vi. 168.

The reign of Ramses, the head of the Nineteenth Dynasty, was evidently brief; the date of only his second year being found on the monuments. He completed some of the columns at Luxor; set up a large stela at Wadi Halfa in Nubia; and his unfinished tomb has been discovered in the Royal cemetery at Bab-el-Meluk.

Meneptha Sethos, the second king of the Nineteenth Dynasty, made additions to the temple at Karnak; commenced the temple at Gurna; and set up obelisks (one of which is now at Rome). His name has been found on other monuments throughout Egypt and Nubia; on the cave-temple near Benihassan; at Wadi-el-Moyeh, in the Desert of the Thebaid towards the Red Sea; at Sarbut-el-Khadem; at Elephantine; and at Silsilis, on an excavated chapel bearing the date of the twenty-second year of his reign.

The completion of the Egyptian Cycle of time or Great Year, in B. C. 1413, appears to have taken place under this king. The subject will be again noticed; with ancient computations in which this date falls in the "fifth year of Concharis ;"* in verification of a statement, derived in all probability by Syncellus from Manetho.

Meneptha Sethos carried on foreign wars: and among the records of his conquests on the temple at Karnac, the scene containing tufts of fern and a forest of fir-trees (Abies picea) could not have been 'nearer than Lebanon (Rosselini, I. Pl. 46). The tall flag-staffs placed on the Pharaonic temples, were doubtless trunks of fir or pine, imported by sea, and probably from Syria.

The plant in the hands of an Asiatic captive at Gurna (Champol-

*-The three Acencheres hold the same position in Manetho's list, as Meneptha Sethos does on the monuments. 
lion, Pl. 167), may be compared with the 7ucerne (Medicago sativa).Pliny states, that the "medica" or lucerne, was "brought from Media into Greece during the wars of Darius :" the plant is also noticed by Aristotle, Theophrastus viii. 8, and Virgil ; and was seen in Egypt by Clot-Bey and Figari, cultivated for feeding cattle.

On the walls of the tomb of Meneptha Sethos, the people of the North (Champollion-Figeac, Pl. 1) have black nut-gall markings on the skin. I found this custom still extant in Yemen, the material being doubtless derived from the oaks of Syria and the country around the sources of the Euphrates.-The oak (Quercus) is mentioned in the Books of Moses; and is said to be indigenous as far south as Palestine: trees have been planted even at Thebes, as appears from Theophrastus; but the grove had become extinct in the time of Pliny; and oaks are now so rare in Egypt, that I met with them only in the Butanic Garden at Cairo.

In the original painting in the tomb, there is an appearance of fur, or perhaps of downy feathers, upon the cloaks of these people of the North.

This tomb was opened by Belzoni, and among the movable articles found therein, were wooden statues coated with bitumen: mentioned by Birch, as the earliest evidence hitherto discovered of the use of bitumen in embalming. This material is supposed to have been brought by land from the valley of the Euphrates.

Ramses II., the third king of the Nineteenth Dynasty, conducted military campaigns both in Asia and on the Upper Nile. His constructions are more numerous than those of any other king, and are scattered all over Egypt and Nubia: but notwithstanding the vast size and costliness of many of them, a Decline of the Arts is manifest; strikingly parallel to that which took place at a later period of the World's history under the Romans.

Ramses II. has left several important historical documents; and especially, the Genealogical Tablet at Abydos. His campaigns are narrated in a poetical form in the Sallier Papyrus. His name has been found as far up the Nile as Barkal, in Dongola; and the date of the sixty-second year of his reign is inscribed on a stela, now in the Museum at Florence. A finely executed portrait of this king in polished syenite, is in the possession of Mr. Francis C. Lowell, of Boston.

A remark of Manetho respecting names, deserves notice in this 
place: for if Egypt derived its Oriental name of Mussera from Ramessu or Ramses, this will limit the antiquity both of the Mizraim of the Hebrews, and of the Ermes or Hermes of the Greeks.

Smiths working iron, are represented on the monuments (Rosselini, II. Pl. 50): and I found the triangular bow figured on the Ramesseum, or the great temple built by Ramses II. at Thebes. - The triangular bow is again figured on the temple at Medinet-Habu : and according to our English Version, metallic bows are mentioned in Job xx. 24, and in 2 Samuel xxii. 35. Iron, according to Gesenius, is mentioned in Genesis iv. 22, Deuteronomy xxvii. 5, Psalm cr. 18, Isaiah xlviii. 4, and in other portions of the Hebrew Scriptures. Hesiod (Op. and Di. 151) refers to a traditional period when the use of iron was unknown.

The plant figured in the great cave-temple at Abu Simbel (Champollion, Pl. 5), and also on other monuments (Rosselini, III. Pl. 5, I. Pl. 19, and Champollion, Pl. 273), is perhaps the scammony, Convolvulus scammonia.-The drug scammony is mentioned by Antiphanes, Theophrastus, Cato, and Athenæus; and the living C. scammonia was seen by Sibthorp in Rhodes, and by Hasselquist at Damietta. The $C$. Siculus, which in some respects agrees better with the above figures, was seen by Delile, growing spontaneously at Alexandria.

The hieroglyphic word "sschin" (Champollion, Dict. 392), may be compared with the "shshn" of 1 Kings vii. 19, 2 Chronicles iv. 5, Solomon's Song, and Hosea xiv. 18, and with "susann" the current Egyptian name of Pancratium Illyricum.-This plant was seen by Forskal (p. 209) in gardens at Alexandria: and the P. maritimum, usually regarded as a distinct species, was found indigenous in that vicinity by Delile.

The hieroglyphic word "tat" (Salvolini) may be compared with "tut," the current Egyptian name of the black mulberry (Morus nigra). - The "moron" of Eschylus (in Phrygibus) is referred by Athenæus to the "sykaminos" of Eubulus, Amphis, Theophrastus, Pythermus, and Hegesander, admitted to be the M. nigra. This tree was seen by Bory de St. Vincent, cultivated in Greece; and by Forskal and others, in the gardens of Egypt.

The name of Meneptha II., the fourth king of the Nineteenth Dynasty, has been found in various parts of Egypt; at Silsilis; at San, or Zoan; on some of the temples at Thebes ; and in his own tomb at Bab-el-Meluk. I met with this king's name in an excavated chamber 
or tomb about three miles above Girgeh and eastward of the Nile; near some mounds of rubbish that mark the site of an ancient city, possibly of the lost Lepidotum.

The tomb of Meneptha III., the fifth and last king of the Nineteenth Dynasty, has been found at Bab-el-Meluk; and his name occurs also on some of the temples at Thebes.

The reign of Merrira, the first king of the Twentieth Dynasty, appears to have been brief. He is chiefly known from having appropriated the tomb of one of his ancestors at Bab-el-Meluk: but according to Gliddon, his name occurs also in the Queens Valley at Thebes, and on a column now in the Museum at London.

Ramses III., the second king of the Twentieth Dynasty, built the great hall of the temple at Medinet-Habu : but notwithstanding its vast dimensions, the walls barely afford room to record his battles. In one of them, the number of the enemy left dead upon the field, is set down at twelve thousand five hundred and thirty-five. And nations not previously figured, now make their appearance.

A naval combat is also represented; and from Manetho and the statement of the Theban priests to Germanicus (Tacitus ii. 60), the two foreign nations fighting the Egyptians should be the Phonicians and the Greeks of Cyprus. The timber of at least the foreign vessels, was doubtless procured in Syria, Asia Minor, or European Greece.

In another part of the temple at Medinet-Habu, Ramses III. is represented playing games, like draughts or chequers, with his daughters. According to Manetho (Josephus, C. Apion i. 15), this king or his brother, would seem to be the Danaus of the Greeks.

I did not find the pigeon distinctly represented on the Egyptian monuments: the figure at Medinet-Habu bears little outward resemblance, but from some attendant circumstances is referred by Wilkinson to the carrier pigeon.-The common domestic pigeon is mentioned by Homer and Herodotus; and carrier pigeons, by Pherecrates, Athenæus, and the Pseudo-Anacreon.

Ornamental wood-work appears to have been carried to great perfection at Thebes during the reign of Ramses III. Cushioned chairs are figured in his tomb; together with other cabinet furniture, richly carved, and presenting some unexpected coincidences with the most approved patterns of the present day.

The Cucurbitaceous plant figured in this tomb, having serrated cordate leaves, but devoid of fruit, is perhaps the gourd (Lagenaria).- 
A similar figure occurs in the tomb of a later king of this dynasty. The gourd is distinctly mentioned by Aristophanes, Theophrastus, Cato and Pliny; is figured by Matthioli; and is cultivated in Egypt and in the other Mediterranean countries at the present day.

A portrait of Ramses IV., the third king of the Twentieth Dynasty, has been found on the walls of the temple at Karnak. His name occurs also in his tomb at Bab-el-Meluk; on the temples at Medinet$\mathrm{Habu}$, and Elephantine; and on various movable articles, now in the museums of Europe.

The name of Ramses $V$., the fourth king of the Twentieth Dynasty, has been found in his tomb at Bab-el-Meluk; also, on the temples at Karnak and Medinet-Habu ; on an-obelisk; on a stela, at Sarbut-elKhadem in the Sinai Peninsula; and on movable articles, now in the museums of Europe.

The tomb of Ramses VI., the fifth king of the Twentieth Dynasty, has been found at Bab-el-Meluk; and his name is inscribed in the order of succession upon the temple at Medinet-Habu.

The name of Ramses VII., the sixth king of the Twentieth Dynasty, is inscribed in the order of succession at Medinet-Habu; and a tomb supposed to be that of this king, has been found at Bab-el-Meluk.

About this time, other nations begin to furnish historical records. Some of the remains at Nineveh, and also in Greece and Italy, are probably as ancient as the Twentieth Egyptian Dynasty, but none have been traced with certainty so far back. Notwithstanding the variety of sculptures and inscriptions, and the paintings on the ancient pottery, it is surprising how little aid in our immediate inquiry can be obtained from the monumental history of Greece and Nineveh.

Our principal dependence henceforward, is on transmitted writings, or written history: for we have arrived at the lifetime of individuals whose words are extant; and eye-witnesses are accessible in all succeeding generations down to the present day.

The "bdlh" of Genesis ii. 12, and Numbers xi. 7, is referred by Josephus and others to the "bdellion."-Pliny speaks of the "bdellium" as the gum of a Bactrian tree, and likewise distinguishes "bdellium Indicum." Bdellium is an aromatic gum, said to be the product of Amyris commiphora, an indigenous tree of Hindostan. 
The "shyh" of Genesis ii. 5 and xxi. 15, and Job xxx. 4 and 7 may be compared with the "schea" of Haly Abbas and Avicenna, and with "shyeh," the current Egyptian name of the Artemisia Judaica.This is an indigenous plant of the Desert of Suez and Palestine; but, according to Delile, is collected and sold for medicinal purposes at Cairo.

The "kwtz" of Genesis iii. 18, Isaiah xxxii. 13, and Jeremiah iv. 3, may be compared with "kus," the current Egyptian name (according to Forskal) of Senecio Arabicus.-This plant was found by Forskal and Delile, growing as a weed at Cairo. The S. vulgaris was also seen by Delile at Damietta.

The "drdr" of Genesis iii. 18, and Hosea x. 8, may be compared with "tartir," the current Egyptian name of one or more Salsolaceous plants; incuding the Salsola articulata, and (according to Delile) the Suoda hortensis. - The first of these is confined to the Desert; but the latter, according to Forskal, becomes a weed in the gardens of Cairo and Yemen.

The "zyt" of Genesis viii. 11, Exodus xxvii. 20, Leviticus xxiv. 2, Judges ix. 9, and Micah vi. 15, may be compared with "zeytoon," the current Egyptian name of the otive (Olea Europea).- The "elaia" or olive, is mentioned by Homer: but in the time of Tarquinius Priscus (according to Fenestella), was unknown in Italy, Spain, or Barbary. Pliny speaks of trees growing around the Egyptian Thebes.

The "gml" of Genesis xii. 16 and xxxvii. 25, Leviticus xi. 4, Deuteronomy xiv. 7, Judges vii. 12 and viii. 26, 1 Kings x. 2, and Job. i. 3, is admitted to be the "djemmel" of modern Egypt, or the camel (Camelus dromas).- The camel is figured at Nineveh, and on the Himyaritic monuments of Yemen; but not on the Egyptian monuments. This exclusion may have been through design; for the Egyptians during some centuries appear to have prevented the diffusion of the camel in the West. Herodotus speaks of the camel only as inhabiting the East; and in the time of the Romans, the animal was so rare in Numidia as to be only once mentioned (Cæsar, Bell. Afr. 68). Its final introduction, carrying population into districts previously uninhabitable, must have produced a revolution in society throughout North Africa.

The "oadsh" of Genesis xxv. 34, 2 Samuel xvii. 28 and xxiii. 11, and Ezekiel iv. 9, may be compared with "a'ds," the current Egyptian name of the lentil (Ervum lens).-Lentil pottage, conspicuous from its 
"red" colour, continues to be a favourite article of diet with the Egyptians.

The "dgn" of Genesis xxvii. 28, Numbers xviii. 27, Deuteronomy xxviii. 51, Lamentations ii. 12, and the "d'hn" of Ezekiel iv. 9, may be compared with "dokhn," the current Egyptian name of the Pennisetum (already mentioned), and also of the millet (Echinochloa Italica).-The "kegchros" is mentioned in the Hesiodic Poems, and Herodotus speaks of its being cultivated both at Babylon and on the Borysthenes; a geographical range corresponding with that of the millet. I frequently met with fields of millet, both in Upper and Lower Egypt.

The "lwz" of Genesis xxx. 37, may be compared with "louz," the current Egyptian name of the almond (Amygdalus communis),-The almond is mentioned under its current Greek name by Ctesias, Xenophon, and other ancient writers.

The "lbnh" of Genesis xxx. 37, and Solomon's Song iv. 6 and 14, may be compared with the "libanotis" of Theophrastus and Dioscorides, admitted to be the rosemary (Rosmarinus officinalis).-This shrub grows to a large size, and is a favourite in the gardens of Egypt.

It should be observed, however, that in the Somali country the term "lubanum" is applied to all gum-like articles of commerce: and that in Hosea iv. 13, the "lbnh" appears to be a tree. According to the Septuagint and Arabic Versions, the "lbnh" of Genesis xxx. 37, is the Styrax officinalis; an indigenous tree, not to be found in irrigated gardens, though perhaps within reach on the neighbouring mountains. -The "styraka" of Herodotus iii. 107, and Pliny xii. 55, according to the received opinion and Greek usage, is gum storax (the product of S. officinalis): the living tree has been seen by Sibthorp and others, on the mountains of Syria, Cyprus, and Greece.

The "tzry" of Genesis xxxvii. 25 and xliii. 11, Jeremiah viii. 22, and Ezekiel xxvii. 17, may be compared with "oschar," the current Egyptian name of the Asclepias procera (Calotropis).-A sugar-like substance is obtained from this plant in Persia (according to Serapion, De temp. simplic. 50, and Ange de Saint-Joseph, as quoted by Delile). I met with the plant in the Desert of the Thebaid; and though unknown in Lower Egypt, it reappears (according to Hasselquist and Lynch) in the region around the Dead Sea.

The "br" of Genesis xli. 35 and 49, Psalm lxv. 13, Proverbs xi. 26, Joel ii. 24, and Amos v. 11, may be compared with the "pyros" of 
Homer, with the Latin "far," and with "burr," the current name in Yemen (according to Forskal) of one of the kinds of Triticum.Herodotus states, that the presents sent by the Hyperboreans to Delos were wrapped in the straw of the "pyros:" and by some writers, the Latin "far" is referred to the spelt (Triticum spelta). Belon appears to be the only modern traveller who has seen spelt in Egypt.

The "btnm" of Genesis xliii. 11, may be compared with "botm," the current Egyptian name of the imported berries of the terebinth (Pistacia terebinthus).-The "terebinthos" of Xenophon (Anab. iv. 4, 7), and Josephus (Bell. Jud. iv. 9, 7), is admitted to be the terebinth : a tree well known at the present day in Syria and Greece. Belon mentions a tradition, that the Persians lived on its berries before becoming acquainted with bread.

The "seneh" of Exodus iii. 2, 3, 4, and Deuteronomy xxxiii. 16, is by some writers referred to the "sena" of the modern Egyptians: and the geographical range corresponds with that of the "sena gebely" or Cassia obovata.-I found this plant growing in the Desert at the head of the Red Sea; and Forskal met with it, also in the Desert near Cairo.

According to the Septuagint Version, the biting fly (Stomoxys) is mentioned in Exodus viii. 21, and Psalm 1xxviii. 45.-The insect resembles, and is often mistaken for the house-fly; but is separately and distinctly mentioned by Homer (Il. xxi. 294), Philon Judæus (De vita Mosis ii.), and Tertullian (Adv. Marcion. i. 14).

The "mrrym" of Exodus xii. 8, may be compared with " murreyr," the current Egyptian name (according to Delile) of Picris altissima. -The Septuagint Version agrees; as appears from the Greek name taken in connexion with Sibthorp's account of a species of Picris eaten in Greece.

Hermas iii. 9, 20, refers the "mrrym" of Exodus to the Centaurea calcitrapa.-A plant distinctly characterized by Theophrastus vi. 5; and abundant in Lower Egypt, where it likewise bears the name of "murreyr."

The "azwh" of Exodus xii. 22, Leviticus xiv., and Psalm li. 9, may be compared with the "yssopos" of Theophrastus, and with "yssopo," the current Greek name of Satureja juliana.-This plant is indigenous in Greece : and two kinds, the wild and the cultivated, are mentioned by Theophrastus. Forskal (Mat. Med.) speaks of the importation of "hyssopus" into Egypt from Palestine.

The "mr" of Exodus xxx. 23, Psalm xlv. 8, Proverbs vii. 17, and 
Solomon's Song v. 5, is admitted to be the "mur" of Modern Egypt, our well-known myrrh.-Herodotus ii. 40, speaks of "smyrna" or myrrh : and the tree which produces it, appears to have been known to Theophrastus. The Somali country is the principal source of the myrrh of commerce; but I learned at Mocha, that a portion is really produced in Yemen.

The "knmwn" of Exodus xxx. 23, Proverbs vii. 17, and Solomon's Song iv. 14, is admitted to be cinnamon. And the etymology of the name (as already stated) implies intercourse with China; or at least. with the Indo-Chinese countries._- "Kinnamomon" or cinnamon, is mentioned by Herodotus iii. 111, and by other Greek writers.

The "kdh" of Exodus xxx. 24, and Ezekiel xxvii. 19, may be compared with "kadi," the current name in India and Yemen (according to Rheede and Forskal) of the Pandanus odoratissimus.-A fragrant oil prepared with this plant, is mentioned by Rhazes, Serapion, and Ibn Baitar.

The "hlbnh" of Exodus xxx. 34, is usually referred to the "chalbane" of Theophrastus ix. 7, Celsus, and Dioscorides, or our modern galbanum.-Theophrastus and Pliny speak of the "chalbane" as the product of a Syrian ferulaceous plant: and according to Forskal (Mat. Med.), gum galbanum is imported into Egypt from Persia.

According to Beckmann, lead is mentioned in Numbers xxxi. 22.And also by Herodotus iii. 56, and other ancient writers.

The name of Ramses VIII., the seventh king of the Twentieth Egyptian Dynasty, has been found on the monuments; together with the date of the third year of his reign.

Ramses IX., the eighth king of the Twentieth Egyptian Dynasty, founded the temple of Khons at Thebes. His name also occurs on other temples; and in his own tomb at Bab-el-Meluk; together with the date of the sixth year of his reign.

Cadmus lived "about one hundred and thirty years before the fall of Troy" (Castor, Eusebius; and Clinton i. p. 86); and according to the belief of Sophocles, Herodotus, Aristotle, and ancient writers generally, he introduced the alphabet from Phonicia into Greece.

The name of Ramses X., the ninth king of the Twentieth Egyptian Dynasty, has been found in his tomb at Bab-el-Meluk; and on other monuments; together with the date of the seventeenth year of his reign.

The name of Ramses XI., the tenth king of the Twentieth Egyptian 
Dynasty, has been found in his tomb at Bab-el-Meluk; and on other monuments; together with the date of the second year of his reign.

The name of Ramses XII., the eleventh king of the Twentieth Egyptian Dynasty, has been found in his tomb at Bab-el-Meluk: a great religious procession, which took place during his reign, is represented at Gurna.

From the etymology, it has been conjectured, that Jephthah's daughter became the Iphigeneia of the Greeks. Homer, it is worthy of remark, is silent respecting Iphigeneia.

The name of Ramses XIII., the twelfth king of the Twentieth Egyptian Dynasty, has been found in his tomb at Bab-el-Meluk.

The inscriptions on the Tripods of Amphitryon and Laodamas, seen and copied by Herodotus v. 59 and 61, were in the "Cadmean Letters," and in pure alphabetic writing.

The same inscriptions are perhaps the most ancient specimens of Greek literature, at present known.-Homer speaks of hymns to the gods, recited during the Trojan war; and gives the name of one of the poets who preceded him, Thamyris (Il. i. 472 and ii. 594).

Hercules is regarded by Homer and Clinton (i. p. 78) as a real historical personage; a military chieftain, who wore armour, led an army, and who died "twenty-six years before the fall of Troy."

The honey-bee (Apis), is mentioned in the history of Samson (Judges xiv.) - And among Greek writers, by Homer and Hesiod.

The end of the Trojan war is placed by Callimachus in B. C. 1127 (Clinton i. p. 140) : and Manetho identifies the Pharaoh of the Odyssey with King Thuoris. If in the Africano-Manetho Table of chronology, we count downwards from the "fifth year of Concharis" or Acherres (the completion of the cycle), the above date will fall in the first year of King Thuoris. If, however, we count from the same point in Josephus, the last year of King Thuoris will fall in B. C. 1072; and the difference, will be 55 years 10 months.*

\footnotetext{
* This difference or uncertainty of 56 years or fourteen olympiads, often makes its appearance in the chronological computations of the Greeks. According to Africanus, The first registered olympiad (B. C. 776) was the Fourteenth: and we find the difference of fourteen full olympiads, in the Olympiad of Iphitus, placed by Callimachus and Africanus in B. C. 828 , and by Eratosthenes in B. C. 884 ; and in the Fall of Troy, placed by Callimachus and Africanus in B. C. 1127, and by Eratosthenes in B. C. 1183. Phanias of Eresus omitted "fifty-five years" between the Return of the Heraclidæ and the registered Olympiads (Clinton i. p. 128 and 139); and we find the latter interval, between B. C. 1257, the date assigned by Callimachus to Cadmus, and B. C. 1312, given by Hales as the current Jewish date of the Exodus.
} 
Some similarity in names may be remarked, between Thuoris, called Proteus by Homer and Herodotus, and Peher Sesamen, the fifth king of the Twenty-First Egyptian Dynasty. The name and portrait of Peher Sesamen have been found on the temple of Khons at Thebes; together with evidence, that he was by profession a priest.

The "rwsh" of Deuteronomy xxxii. 32, and the "rash" of Deuteronomy xxix. 18, Psalm lxix. 27, Amos vi. 12, Hosea x. 4, Job xx. 16, Jeremiah ix. 15, and Lamentations iii. 19, may be compared with the "mekon roias" of Theophrastus; usually referred to the fieldpoppy (Papaver rhæas.) - This species, together with the P. hybridum, were seen by Sibthorp in Greece; and by Forskal and Delile, growing spontaneously around Alexandria.

The "lonh" of Deuteronomy xxix. 18, Proverbs v. 4, Amos v. 7, Jeremiah ix. 15, and Lamentations iii. 19, may be compared with the "balin" of Xanthus and Pliny xxv. 5, and with "beloni," the current Greek name of the Caucalis daucoides. The frequent association of the "lonh" and "rash," suggests the "koneion" of the Ancient Greeks; a poison known to have been composed partly of poppy juice.According to Delile, the C. daucoides was received from Egypt by Reichard.

The "khwkh" of the history of Saul (1 Samuel xiii. 6), and of Proverbs xxvi. 9, Solomon's Song ii. 2, Isaiah xxxiv. 13, and Job xxxi. 40, may be compared with "chouk," given by Delile as the current Egyptian name of several thorny plants, including the Cirsium Syriacum.-This thistle, according to Sibthorp, abounds in the Grecian Archipelago and in Cyprus.

The flea (Pulex), according to the received opinion, is mentioned in the history of Saul (1 Samuel xxiv. 14).-Among Greek writers, the flea is distinctly noticed by Aristophanes (Nub. 145 and 831).

The name of Pianch, the sixth king of the Twenty-First Egyptian Dynasty, and also a priest, has been found on the monuments by Lepsius.

The "pwl" of the history of David (2 Samuel xvii. 28), and of Ezekiel iv. 9, may be compared with the "fabula" of Plautus, and with "fool," the current Egyptian name of the bean (Vicia faba).At the present day, this plant is one of the principal objects of cultivation in Egypt; for the sake of both the seeds and stems.

The "rtm" of Psalm exx. 4, and of the history of Elijah (1 Kings xix. 4), is admitted to be the "rætæm" of the modern Egyptians, 
Spartium monospermum.-This is an indigenous plant of the Desert of Suez and the Sinai Peninsula; where the charcoal obtained from it, forms an article of traffic with Egypt.

The name of Pischam Miamn II., the seventh and last king of the Twenty-First Egyptian Dynasty, and also a priest, has been found on the temple of Khons at Thebes.

The manufacture of leather, has been traced in mummies as far back as the Twenty-First Dynasty, by means of the stamped leather bands, mentioned by Birch._-Similar bands, of morocco leather, stamped with the name of a king of the Twenty-Second Dynasty, were found in the mummy recently opened at Boston. I procured at Thebes, pegged morocco shoes, taken from mummies and penetrated with bitumen ; together with part of a sash of soft leather, having the margin cut, as if by machinery, into lace-like fringe.

In reference to the "almug trees" brought in the ships of Solomon (1 Kings $\mathrm{x} .12$, and 2 Chronicles ix. 11); I ascertained, that the joists used at Mocha for supporting the floors and flat roofs, are imported ready-hewn from Zanzibar.

The "twkyym" imported in the ships of Solomon (1 Kings x. 22, and 2 Chronicles ix. 21), are referred by Hieronymus, and by Syriac and Hebrew authorities, to the peacock. This bird, in its wild state, is known to be peculiar to Hindostan: and I am informed by Mr. Hoisington, that the name "twkyym" belongs to the Tamil language. -Among Greek writers, the peacock is mentioned by Eupolis, Aristophanes, Strattis, Anaxilaus, Menodotus, and Athenæus.

The "ktzyowt" of Psalm xlv. 8, may be compared with "keschut;" given by Forskal (Mat. Med.) as the current Egyptian name of certain seeds, imported from Syria and used as a cosmetic, especially by the Jews.-The plant, however, remains unascertained.

The "bshm" of Solomon's Song v. 13 and vi. 2, may be compared with "abuscham," the current name in Yemen of the balm-tree (Amyris opobalsamum). - Josephus mentions a tradition, That the balm-tree was introduced into Palestine by the Queen of Sheba; and Strabo's account of its place of origin corresponds. After the time of the Romans, the balm-tree disappeared from the valley of the Jordan; but "living plants brought at great expense from Yemen," were seen by Belon in a garden near Cairo. The re-introduction proved unsuccessful; for, thirty-one years later, the stocks could not be found by Alpinus. 
The "hdk" of Proverbs xv. 19, and Micah vii. 4, may be compared with "hadak," the current name in Yemen of the Solanum cordatum. - This species has not been observed further north; but the allied S. coagulans was seen by Delile at Syene. According to Forskal, The property of coagulating milk is common to all plants of this genus.

The "hrwl" of Proverbs xxiv. 31, Job xxx. 7, and Zephaniah ii. 9, may be compared with "karilli," the current Egyptian name of the Sinapis Allionii.-This is a species of wild mustard, observed by Delile growing among the flax crops of Egypt.

The "kmsn" or "kymwsh" of Proverbs xxiv. 31, Hosea ix. 6, and Isaiah xxxiv. 13, may be compared with "hemsis," given by Forskal (p. 77) as the current Egyptian name of a species of sorrel (Rumex roseus).-The $\mathrm{R}$. roseus, according to Sibthorp, is also found in Cyprus.

The "tpwh" of Proverbs xxv. 11, Solomon's Song ii. 3, and Joel i. 12, may be compared with " tiffah," the current Egyptian name of the apple (Pyrus malus).-The apple is noticed by Sappho, Theocritus xi. 39, Cato, Tibullus v. 31, and in the Copa: at the present day, the tree is very generally cultivated in the Arab countries, notwithstanding the inferior quality of the fruit.

The house-fly (Musca domestica), is mentioned in Ecclesiastes x. 1 . -And also by Homer, and other Greek writers.

The "krkm" of Solomon's Song iv. 14, is referred by Gesenius to the turmeric (Curcuma longa); and according to Graham, The name "kurcum" is sometimes given to turmeric at Bombay.-The "Indian kyperos" of Dioscorides and Pliny, is by some writers referred to the turmeric; and the imported root is well known in Egypt, as appears from Alpinus iv. 13.

The "kpr" of Solomon's Song i. 14 and iv. 13, may be compared with the "kapparis" of Aristophon, Timocles, Clearchus Solensis, Plautus, and Athenæus, and with "kabar," the current Egyptian name of the caper bush (Capparis spinosa).-The berry-like flower-buds of this plant have long formed an article of commerce in the Mediterranean countries.

The "agwz" of Solomon's Song vi. 11, may be compared with "gios," the current Egyptian name of the walnut (Juglans regia).The walnut is noticed by Epicharmus, Sophocles, Philyllius, and Athenæus ii. 38: and by Theophrastus, under the name "karya Persike;" as appears from Pliny's referring to the Greek name for 
proof "that the tree was originally brought from Persia." The walnut tree was seen by Hasselquist in Palestine; but its cultivation in Egypt is regarded as recent.

The "nrd" of Solomon's Song i. 12 and iv. 13, may be compared with "uard," the current Egyptian name of the rose: and indeed, the notice of the "nardos" in Mark xiv. is sufficiently descriptive of the essential oil or attar of roses.-Homer, Celsus, and Pliny mention a fragrant oil of roses. And Theophrastus alludes to the presence of the rose in Egypt: where, though foreign to the natural vegetation, it is cultivated for commercial purposes at the present day.

An evident connexion is found in the modern Greek application of term "nardos" to the lavender and its essential oil; also, in the "iphyon" of Epicharmus, Theophrastus, and Athenæus ii. 83, being by some writers referred to the lavender. Sibthorp met with the Lavandula spica in Greece; and Delile found an allied species in the Egyptian Desert (perhaps the same seen by myself in Yemen and in the Dekkan). The L. stoechas is frequent throughout the Grecian Archipelago; but according to Clot-Bey and Figari, has been only recently introduced into Egypt.

However, the "nardos Indikos" mentioned by Theophrastus and Pliny, is referred by Garcias and Royle to the root of Nardostachys jatamansi: an indigenous plant of Hindostan.-The importation of Indian nard is also mentioned by the Arab medical writers.

The Africano-Manetho numbers (counting from the "fifth year of Concharis," and omitting the years assigned to the Twentieth Dynasty), give B. C. 991 for the accession of Scheschenk, the first king of the TwentySecond Dynasty : and we obtain the same date from the old Egyptian Chronicle (for $194+228=422=83+209+130$ ). Scheschenk, or Shishak, ruled Egypt before the death of Solomon (1 Kings xi. 40, and 2 Chronicles x. 2), and captured Jerusalem " in the fifth year of Rehoboam" (1 Kings xvi. 25, and 2 Chronicles xii. 2). A record of this event, together with a portrait of King Scheschenk, was found by Champollion on the walls of the temple at Karnak. King Scheschenk commenced the great unfinished hall at Karnak; and the date of the twenty-second year of his reign has been found on a stela at Silsilis.

Userkan, the second king of the Twenty-Second Egyptian Dynasty, continued the unfinished hall at Karnak: his name has also been found on the great temple at Bubastis in Lower Egypt; on a papyrus; and on a vase, once in the possession of the ancient Roman family 
of Claudia. He, or one of his successors bearing the same name, is supposed by Champollion and others, to be the "Zerah" who was defeated by Asa (2 Chronicles xiv. 9).

The name of Peher, the third king of the Twenty-Second Egyptian Dynasty, has been found on the monuments by Lepsius.

The name of Userkan II., the fourth king of the Twenty-Second Egyptian Dynasty, has been found on the monuments by Lepsius.

The name of Scheschenk II., the fifth king of the Twenty-Second Egyptian Dynasty, has been found on the monuments by Lepsius.

The name of Takelet, or Tiglath, the sixth king of the Twenty-Second Egyptian Dynasty, has been found on the monuments; together with dates of the eleventh and fifteenth years of his reign.

From examples already given, it will be perceived, that the names of animals and plants used in Egypt are the Scriptural names. Further, in some instances, these current Egyptian names go behind the Greek language, supply the meaning of obsolete Greek words, and show international relationship, the more intimate the further we recede into antiquity.

In Egypt, the white poplar (Populus alba), is called "hour:" the AXEPSIE of Homer and Hesiod is but the same word softened into the Greek idiom.-And at a later period, we find the tree called "leyke" by the Greeks. Theophrastus expressly alludes to the presence of the "leyke" in Egypt.

The make $\Delta$ Nhe aireipoio of Homer, Od. vii. 106, is perhaps the Populus nigra (already mentioned); but may also be compared with the aspen (Populus tremula).-The aspen was seen in Greece by Belon and Sibthorp; and according to Clot-Bey and Figari, is cultivated in gardens at Cairo.

In Egypt, the chick pea (Cicer arietinum) is called "hommos:" and the күамог of Homer can be readily identified.-The shape of the seed, singularly resembling a ram's head, may account for the "kyamos" being regarded unclean by the Egyptians of the time of Herodotus.

In Egypt, the edible lupine is called "termes :" and in this word we

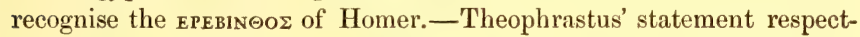
ing " the woody stem of the erebinthos" corresponds ; but in later times, we find the Greek name transferred to a different plant.

The $\mathrm{M} \Omega \Delta \mathrm{x}$ of Homer, Od. x. 302, is referred by Dioscorides and Galen to the "armala;" and may be compared with "harmal," the current Egyptian name of Peganum harmala.-This is an indigenous 
plant of the Desert; but according to Belon, the Arabs make constant use of the seeds, from a superstitious belief, That they are a preservative against Evil Spirits.

As to the MHAON of Homer and Hesiod (a plant in all probability not received from Egypt), the circumstance of the Greek word equally signifying a sheep, seems to cover an allusion to the downy coating of the quince (Cydonia vulgaris).-The quince is distinctly mentioned by Stesichorus (quoted by Athenæus); and in a law of Solon, referred to by Plutarch (Conjug. præcept. 1): the "malum" of Virgil seems also to be the quince. I have uniformly found the quince succeeding better than the apple in the Arab countries.

The mEAla of Homer, Hesiod, and Aristophanes, according to Sibthorp's account of the Greek usage, is the Fraxinus ornus.- Theophrastus states, that the "melia" and "boymelia" grow in Egypt: and the F. ornus and $F$. elatior are enumerated by Clot-Bey and Figari among the trees planted there in gardens. Seeds of the F. ornus, were seen by Delile in the drug shops of Cairo.

The Greek name MEAIA seems to imply a knowledge of the drug manna, a product of one or more species of Fraxinus.-And Diodorus Siculus xvii. 75, Curtius vi. 4, Polyænus iv. 3, 32, and Athenæus xi. 500, expressly mention an oak-like tree that distils honey. Other plants, however, besides the species of Fraxinus, yield manna. The "elaiomeli of Palmyra" mentioned by Dioscorides, Pliny, and Paulus Egineta, is referred by Rhazes (De Angin. ix. 51) to this drug: and Rauwolf and Tournefort ascertained, That the manna of the Arabs is chiefly procured from the Alhagi maurorum, an indigenous low shrubby plant of the North African and Asiatic Desert.

The osrpa of Homer and Herodotus is by some writers referred to the Latin "far" (already noticed); but the usage in certain parts of Italy indicates the rye (Secale cereale).-The "secale" of Pliny, according to Greek and French usage, is the rye. This is a grain of northern climates; and though cultivated in Syria, Alpinus appears to be the only modern traveller who has seen it in Egypt.

Forskal found the Vicia sativa growing as a weed in Egypt, and called "faurum;" a compound word which admits of being translated, "the far of Rome or Constantinople." The zEA of Homer and Xenophon, according to Zalikoglous' account of the Greek usage, would seem to be a species of Vicia or vetch; and confusion may have arisen from the practice in ancient times of sowing mixed crops. 
The $\Lambda \Omega$ тог herb of Homer, Il. ii. 776, is referred by Bory and Chaubard to the Lotus Argolicus; a plant still serving for pasturage in Greece.-The $L$. corniculatus (which perhaps does not differ) was seen by Forskal and Delile, growing spontaneously at Cairo.

The $\Lambda \Omega$ Tos, however, is by some writers considered identical with the "melilotos;" and the latter is referred by Serapion to the "achilel melich, or Trigonella hamosa.-This plant was seen by Sibthorp in Cyprus; and by Alpinus, Hasselquist, and Forskal in Egypt; where, however, it is perhaps indigenous.

Homer's account of the Lotophagi brings to mind a peculiar conserve, said to be used in child-stealing, and bearing nearly the same Egyptian name as the "helbeh" or fenugreek (Trigonella foenumgræcum).-I found the fenugreek a favourite article of diet with the Parsees of India: and the "triphyllon" of their forefathers (Herodotus i. 132) may be compared.

Homer's account of the Egyptian "nepenthes" drug, is sufficiently descriptive of opium.-Diagoras and Erasistratus condemned the use of opium; and Pliny further speaks of the drug being adulterated at Alexandria, and of the "garden white-poppy (Papaver somniferum) from which it is obtained. Opium is still one of the staple productions of Egypt.

The "saffron-coloured garments," mentioned by Homer, imply a knowledge of the safflower, or dyer's saffron (Carthamus tinctorius).-I found this plant very generally cultivated throughout the Arab countries, from Egypt to the Dekkan inclusive.

The чүгог of Homer, Il. xi. 105, according to the received opinion and Greek usage, is the Vitex agnus-castus. - This shrub is said to abound along river-banks in Greece and Syria: but may not be indigenous; for it belongs to a Tropical genus; and is enumerated by Forskal and others among the garden plants of Egypt.

The "gutran" timber, mentioned by Forskal as imported into Egypt, may be compared with the KE $\Delta \mathrm{PON}$ of Homer (Od. v. 60), Herodotus, and Aristophanes; the current Greek name, according to Sibthorp, of one or more species of juniper; and especially, of the $J$. oxycedrus.-Callixenus (quoted by Athenæus v. 38) states, That the galley of Ptolemy Philopator was partly of "kedros" wood. The importation and medicinal use of juniper-berries in Egypt, is mentioned by Alpinus and Forskal.

The oron of Homer, Callixenus, Pliny, and Athenæus v. 38, is 
usually referred to the Thuya Orientalis.-Theophrastus speaks of the tree growing at the Oasis of Ammon, and in Cyrene, localities in which it must have been planted. The T. Orientalis continues to be a favourite ornamental tree in Egypt; and was found by Belon, growing wild on the mountains of Asia Minor.

The Krnapiszos of Homer, Herodotus, and Thucydides ii. 34, according to the received opinion and Greek usage, is the cypress (Cupressus sempervirens).-A funereal tree with the Ancient Greeks; and planted at the present day in all Muslim cemeteries, from the Mediterranean to Hindostan.

The пітг of Homer (Il. xiii. 390), and Herodotus, may be compared with Pinus maritima.-According to Sibthorp, the P. maritima abounds in Greece, and is the only species found in Cyprus. Forskal speaks of the importation of pine timber into Egypt. And the $P$. Halepensis was seen by Delile in a garden at Cairo; and is enumerated by Clot-Bey and Figari among the plants long known in Egypt.

The $\triangle A \Phi N H$ of Homer (Od. i. 183), Hesiod, and Ibycus, according to the received opinion and Greek usage, is the laurel (Laurus nobilis).The leaves and branches used (according to Callixenus) in the festival of Ptolemy Philadelphus, were probably imported ; for I find no notice of the cultivation of the laurel in Egypt. Alpinus speaks of the medicinal use of the imported berries.

The пrzоs of Homer (Il. xxiv. 268) and Theophrastus, according to the received opinion and Sibthorp's account of the Greek usage, is the box (Buxus sempervirens).-The writing-tablets of the Early Greeks are known to have been usually made of box-wood; and according to the Septuagint Version, such tablets are mentioned in Isaiah xxx. 8. The living plant appears to have remained unknown in Egypt.

The KPANEI of Homer, and Herodotus vii. 92, is considered to be the cormel (Cornus).-Two species are mentioned by Theophrastus; and the C. mascula and C. sanguinea were both seen by Sibthorp in Greece: from which country, according to Clot-Bey and Figari, they have recently been introduced into the gardens of Egypt.

The nteneA of Homer, Hesiod, and Aristophanes (Nub. 1008), according to the received opinion and Sibthorp's account of the Greek usage, is the elm (Ulmus campestris).-This tree was seen by Delile in gardens at Cairo; where, according to Clot-Bey and Figari, it has been long known.

The кАн®Рн of Homer and Theophrastus, according to the received 
opinion and Sibthorp's account of the Greek usage, is the European alder (Alnus glutinosa).-This plant was seen in Egypt by Hasselquist.

The паatanistos of Homer and Herodotus, translated "platanus" by Cicero, is considered to be the Oriental plane (Platanus Orientalis).-According to Pliny, the "platanus" was first brought over the Ionian Sea to adorn the tomb of Diomedes: the trees at this tomb are mentioned by Theophrastus; who also alludes to the presence of the "platanos" in Egypt. I found the P. Orientalis abundantly planted throughout Middle and Lower Egypt.

The ITEA of Homer (Il. xxi. 350, and Od. x. 510), according to the received opinion and Sibthorp's account of the Greek usage, is one or more species of willow (Salix).-The "tzptzph" of Ezekiel xvii. 5, may be compared with "safsaf," the current Egyptian name of the willow. I met with a single young willow, growing, apparently indigenous, by the river-margin in the Thebaid; perhaps the S. subserrata, a species seen by Delile in gardens at Cairo.

The кrnEipos of Homer and Herodotus, according to the received opinion and Greek usage, is one or more species of Cyperus.-Tubers of a Cyperus were unrolled in the Boston mummy, perhaps the $C$. rotundus: a species seen by Sibthorp in Greece; and by Delile, at Alexandria, Rosetta, and Cairo.

The zEAINON EAEO@PEITON of Homer (Il. vi. 39, and Od. v. 32), according to Sibthorp's account of the Greek usage, is the smallage (Apium graveolens).-Rhazes recommends the medicinal use of the seeds of the "carafs" or smallage; and these are enumerated by Forskal among the articles of the Egyptian materia medica; but the living plant, if distinct from the celery (a point which will be again adverted to), appears to be unknown in Egypt.

The Aeipion of Homer (Il. iii. 152) and the Hymn to Ceres 427, and the "lilium" of Virgil, according to Pliny's description (xxi. 11), is clearly the garden 7ily (Lilium candidum).-Neither Forskal nor Delile met with the lily in Egypt; and Clot-Bey and Figari state, that the plant is rarely seen beyond the Pasha's gardens.

The ватог of Homer (Od. xxiv. 230), Pindar, and Theophrastus, according to the received opinion and Sibthorp's account of the Greek usage, is the Rubus fruticosus.-This plant was seen in Palestine by Hasselquist; and by Delile at Rosetta, where it had doubtless been introduced. 
The raKIN@Oz of Homer and others, is referred by Linnæus and Bory de St. Vincent to the Delphinium Ajacis.-The name "ayakbouh," given to this plant in Egypt, favours the reference; as also the accounts of the Greek usage by Forskal, Zalikoglous (article "jacinthe"), and Scarlatus.*

The Ion of Homer and Theophrastus, is usually referred to the Viola odorata.-This plant was seen by Sibthorp in Greece; and according to Clot-Bey and Figari, is a favourite in the gardens of Egypt.

The гпоггог of Homer (Il. xviii. 414, and Od. xx. 151), Plato, Theopompus, and Athenæus, is clearly sponge.-The Eastern portion of the Mediterranean continues to furnish large supplies of this article of commerce.

The HАEктPON of Homer, Hesiod (quoted by Hyginus, 154), and Herodotus iii. 115, is clearly amber; a fossil gum procured on the shores of the Baltic. This light and valuable substance was doubtless transported by land to the Adriatic: and the transfer in ancient times of the name of the Rhone to the Po, seems to indicate the route of this traffic in tin and amber.

The "dbywnym" of the account of the siege of Samaria (2 Kings vi. 25 ) is referred by Linnæus to the Omithogalum umbellatum.-This plant is considered to be the "ornithos gala" of Nicander, Dioscorides, and Athenæus ix. : it was seen by Sibthorp in Greece, and by Hasselquist in Palestine, but appears to be unknown in Egypt. An allied species, the O. Arabicum, inhabiting Barbary, and figured by Rudbeck and Besler, was received from Egypt by Linnæus.

The name of Userkan III., the seventh king of the Twenty-Second Egyptian Dynasty, has been found on the monuments; together with the date of the eleventh year of his reign. The mummy recently unrolled at Boston, contained the name of Userkan III., and proved to be the body of an individual who died during this king's reign.

The nоліом of Hesiod (quoted by Theophrastus ix. 21), and of Musæus, Dioscorides, and Pliny, is referred by Sibthorp and others to the Teucrium polium.-This plant was seen by Forskal in the environs of Alexandria; where, however, according to Delile, it is indigenous.

The Ma $A$ AXH of Hesiod, according to Sibthorp's account of the Greek usage, would seem to be either the common mallow, Malva rotundifolia, or an allied species, M. sylvestris.-In Egypt, I frequently observed

* Modern Greek Lexicon of Scarlatus of Byzantium. By A. Koromelas. Athens, 1839. 
the field-culture of a mallow closely resembling the M. rotundifolia; and M. sylvestris and M. verticillata, are enumerated by Clot-Bey and Figari among the Egyptian esculent plants.

However, the "malache" described by Theophrastus i. 5, is clearly the hollyhock (Alcea rosea); and in this instance also, Greek usage is conformable.-The A. rosea was seen by Sibthorp indigenous on the mountains of Greece. The A. ficifolia (by some considered as only a variety), was also found by Sibthorp indigenous in Greece; was seen by Hasselquist in Palestine; and according to Forskal, is cultivated at Cairo for the sake of the leaves, which are esculent and are used in Egyptian cookery.

The гколтмог of Hesiod and others, according to Sibthorp's account of the Greek usage, is the Scolymus Hispanicus._-This plant was seen by Forskal and Delile, growing spontaneously at Cairo and Alexandria. Another species, S. maculatus, was seen by Delile near Rosetta; and by Hasselquist, in Palestine.

The MAZA* of Hesiod (Op. 590), Achæus, and Herodotus, so far as the origin of the word is concerned, may be compared with "maseh," the current Egyptian name of the pea-bean, Phaseolus mungo.-This plant is mentioned by Maserjawia, Rhazes, and Avicenna; is cultivated in Nubia and Upper Egypt (according to Delile and Clot-Bey); and, as appears from Rabbi Schwarz ii. 2, is well known in Palestine.

The name of Sheschenk III., the eighth king of the Twenty-Second Egyptian Dynasty, has been found on the monuments ; together with the date of the twenty-ninth year of his reign.

The two-humped or Bactrian camel (Camelus Bactrianus) is figured on the monuments at Nineveh and Persepolis, on the Etruscan vases (Layard, Pl. 53 and 55, and Mon. Inediti, Pl. 50), and is mentioned by Aristotle.-The two-humped camel is employed in Central Asia, and in the Crimea and the Caucasian countries; but appears to have always remained unknown in Arabia; and to have been rarely brought even as a curiosity into Egypt.

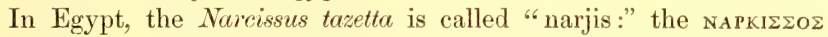
of Pamphos, the Cyprian Verses, the Hymn to Ceres, Theophrastus, and Pausanias ix. 31, may be compared.-Pliny's description, however, agrees better with the $\mathrm{N}$. poeticus; a species which has not been observed in the gardens of Egypt.

* This name, it will be perceived, has been improperly transferred to the grain cultivated by the aboriginals of America; now called "maize" or Indian corn (Zea mays). 
The name of Takelet II., the ninth and last king of the TwentySecond Egyptian Dynasty, has been found on the monuments.

The ztadrainos of Orpheus, Philistion, Phanias of Eresus, Diocles, Dieuches, Cleophantus, Pliny, and Athenæus, according to the received opinion and Sibthorp's account of the Greek usage, is the carrot (Daucus carota).-The description by Dioscorides, corresponds; and at the present day, the carrot is abundantly cultivated in Egypt.

"At the command of the Delphic Oracle, Iphitus restored the Olympian games :" and this Olympiad of Iphitus, is placed by Callimachus, Africanus, and Clinton (ii. p. 500), in B. C. 828. Iphitus, by the general consent of Antiquity, was contemporary with Lycurgus, the Spartan lawgiver; who (according to Simonides and others) was the son of Prytanis, the fifth king of Sparta in the Proclid line.

Manetho (or perhaps Africanus) evidently alludes to the Olympiad of Iphitus in stating, that the "First" Olympiad was celebrated in the time of Petubastes, the first king of the Twenty-Third Egyptian Dynasty. The Africano-Manetho numbers (counting upwards and downwards, from the Nineteenth Dynasty inclusive) give B. C. 825-3 for the accession of Petubastes; and we obtain nearly the same result from the Old Egyptian Chronicle (for $194+228+121+48=591$, and $135+209+130+116=590)$. The name of King Petpacht, or Petubastes, has been found on the monuments by Prisse and Lepsius.

The "kykywn" of Jonah iv. 6, may be compared with the "sikya" or "kikya" of Theophrastus and the early Greeks; admitted to be a variety of the gourd (Lagenaria).-In Egypt, however, the musk-melon (Cucumis melo) is sometimes called "kauun;" and the "sikyos" of Alcæus, Phrynichus, and Aneas Tacticus 29, seems to correspond. The musk-melon is distinctly mentioned by Cratinus (according to Athenæus), and by Galen (De Alimen. Facult. 2), Palladius (Martio 9), and Florentinus (Geoponica xii. 20).

The name of Userkna, the second king of the Twenty-Third Egyptian Dynasty, has been found on the monuments by Lepsius.

The First registered Olympiad, B. C. 776, is placed by Eusebius and the Parian Marble in the second year of the Athenian archon Eschylus; and by Eusebius and Clinton, in the time of the Jewish king Azariah or Uzziah.

The name of Psimut, the third king of the Twenty-Third Egyptian Dynasty, has been found on the temple at Karnac; and also, on the ruins of a small building in the immediate vicinity. 
According to Julius Africanus (as quoted by Eusebius), Eschylus was archon at Athens, when Jotham ruled at Jerusalem: the twentysecond year of Eschylus, is placed in the Parian Marble in B. C. 756 ; and Clinton's computation, makes this the date of the accession of Jotham.

The Old Egyptian Chronicle (counting upwards), gives B. C. 752 for the accession of the Twenty-Fourth Dynasty. This dynasty has not been found on the monuments : and its connexion with the Completion of a phoenix, will be noticed hereafter.

The name of Schebek, the first king of the Twenty-Fifth Egyptian Dynasty, has been found on the monuments. He is considered to be the Sabacon of Herodotus.

The name of Schebek II., the second king of the Twenty-Fifth Egyptian Dynasty, has been found on the monuments; together with the date of the twelfth year of his reign. He is supposed to be the "So" mentioned in 2 Kings xvii. 3.

The "orb" of Isaiah xv. 7 and xliv. 4, Job xl. 22, and Psalm cxxxvii. 2, may be compared with "kharub," the current Egyptian name of the carob-tree (Ceratonia siliqua).-The "keronia" of Theophrastus and Pliny, is admitted to be the carob-tree: and Pliny further states, That it grows in Ionia and Syria, but not in Egypt; where, indeed, it is rarely seen at the present day. The carob-tree has appeared to me to be foreign to the natural vegetation of the Mediterranean countries.

The "notzwtz" of Isaiah vii. 19 and lv. 13, may be compared with "neschusch," given by Forskal as the current name in Yemen of the Inula odora.-This plant is cultivated in Yemen; but has not been observed further North. There are, however, indigenous species of Inula in the Desert of Egypt and Palestine.

The "kmn" of Isaiah xxviii. 25 and 27 , may be compared with the "kyminon" of Aristophanes and Theophrastus (Char. 10 and 19), and with "kammoun" the current Egyptian name of the cummin (Cuminum cyminum).-This plant is still a favorite article of cultivation in Egypt.

According to Gesenius, the mouse (Mus musculus) is mentioned in Isaiah ii. 20.-The mouse is figured in an Egyptian painting, apparently not as ancient as the Pharaonic period; and is also mentioned in the Batrachomyomachia, and by Herodotus and Plautus.

In reference to the internal affairs of Greece: The first Messenian 
war (according to Tyrtæus) lasted nineteen years; and (according to Pausanias) was brought to a close in Olymp. 14, 1, or B. C. 723.

In the sixth year of the Jewish king Hezekiah (2 Kings xvii. 6 and xviii. 10), Shalmaneser captured Samaria; and removed the inhabitants, settling colonial Israelites in Media.-In the account of the Colchians by Herodotus ii. 104, many points of resemblance will be observed.

The series of recorded Babylonian eclipses preserved by Claudius Ptolemy (which has been of great service to historians and chronologers), commences in "B. C. 717" (Alsted), during the reign of Mardoch-Empadus. This king of Babylon is regarded by Clinton and others, as the Merodach Baladan mentioned in 2 Kings xx. 12, and in Isaiah xxxix. 1.

The name of "Thrk," or Tirhakah, the third king of the TwentyFifth Egyptian Dynasty, has been found on a pylon or gateway at Medinet Habu ; also on mummy-cases; and in inscriptions at Gebel Barkal in Dongola, dated in the twentieth year of his reign. Tirhakah is mentioned in 2 Kings xix. 9 ; and also, by Strabo i. and xv.

The Ethiopian queen Amnerith, or Ammeris, is placed by Eusebius immediately after Tirhakah: and she appears to have exercised some authority, at least in Upper Egypt. A mummy-case dated in her reign is described by Birch, and is now in the Museum at London.

In a mummy unrolled at Bristol, Herapath ascertained, that a solution of silver had been employed in the hieroglyphic writing; and further, that the solvent was probably nitric acid.*

Herapath found some of the bandages of this mummy dyed with indigo (Indigofera).-The "indicum" of Vitruvius and Dioscorides, expressly stated by Pliny (xxxv. 27) to be imported from India, is admitted to be indigo: and some centuries later, as appears from the Mishna, and from Abulfeda and Niederstedt, the living plant was introduced into Palestine, Egypt, and Malta. Marco Polo and Nicolo Conti witnessed the manufacture of indigo in Eastern Asia.

The first three kings of the Twenty-Sixth Egyptian Dynasty are known from Manetho: but their names have not been found on the monuments.

The "mlw'h" of Job xxx. 4, may be compared with "mullæah," the current Egyptian name of the Suoda baccata: and perhaps also, of

* London and Edin. Philos. Mag., July, 1852. 
some allied Salsolaceous plants.-The S. baccata was seen by Forskal and Delile, growing as a weed around Cairo and Alexandria.

The "rtm" of Job xxx. 4, is perhaps the Spartium (already mentioned); but Forskal gives "rætæm" also, as the current Egyptian name of the Atriplex coriacea.-This plant was seen by Forskal and Delile, growing in the sands around Alexandria.

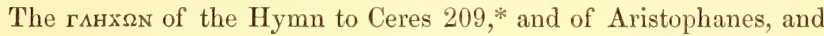
Theophrastus ix. 16, according to the received opinion and Sibthorp's account of the Greek usage, is the Mentha pulegium.-This plant was seen in Egypt by Alpinus; and Delile met with it, apparently indigenous at Alexandria.

The araAnidas of the Hymn to Ceres, or the "anagallis" of Theophrastus, Dioscorides, and Galen, is usually referred to one or more species of Anagallis.-The A. arvensis is enumerated by Delile among the weeds of Egypt.

According to the statement of Herodotus ii. 142, The Egyptian priests reckoned "three hundred and forty-one kings" prior to Psammetichus. In the Africano-Manetho Table of chronology, one hundred and thirteen kings are named; and the unnamed kings of the Seventh, Eighth, Eleventh, Thirteenth, Seventeenth, and Twentieth Dynasties, will make up the desired number (for $113+70+27+16+60+43$ $+12=341$ ). This requires the exclusion of the unnamed kings of the Ninth, Tenth, Fourteenth, Sixteenth, Nineteenth, and duplicate Seventeenth Dynasties.

\section{THE GREEK PERIOD.}

The Africano-Manetho numbers (counting upwards and downwards) give B.C. 669-7 for the accession of Psamtik, or Psammetichus, the fourth king of the Twenty-Sixth Egyptian Dynasty: an accession marked, by the first introduction into Egypt of a body of Greeks (see Herodotus ii. 154). The name of King Psamtik has been found in the unfinished hall at Karnac; in the quarries at Tura; on the rocks

* The Hymn to the Delian Apollo by the Blind poet of Chios, perhaps contains no descriptive expressions derived through the sense of sight: but though quoted and considered ancient by Thucydides, there is a circumstance indicating a later date than the time of Homer. In the Odyssey vi. 165, the date-palm on the Island of Delos is described as young and flourishing; but in the Hymn to the Delian Apollo 18, has become so old that all tradition of its origin is lost.-This date-palm is mentioned by Callimachus (Hymn to Delos) as still standing; but it bad disappeared before the time of Pausanias viii. 48 , and Athenæus. 
near Philæ; on an obelisk, now at Rome; and on a papyrus and other movable articles in the museums of Europe; together with various dates, the latest being in the forty-fifth year of his reign.

The monuments of the Greek Period may be recognised, by a difference in the style of art; by the increased number of hieroglyphic characters, and the general want of care in sculpturing them; by the re-duplication of the deities; and by the absence of all representations relating to manners, occupations, and the mechanic arts.

Demotic Inscriptions have been traced as far back as the TwentySixth Dynasty. Demotic or Enchorial writing, is regarded by Birch as "an outgrowth of the hieratic writing, which it superseded for the legal and ordinary purposes of life ;" and, as " an attempt to assimilate the Egyptian system of writing to the alphabetic Phoenician." In the form of the characters, some general resemblance may be observed between Demotic and modern Arabic writing.

One of the new deities figured, has the head of the cat (Felis).The ambiguous representations at Benihassan, appeared to me after careful examination, to be intended for varieties of the dog. I do not find the cat mentioned in the Hebrew Scriptures, nor by Homer, Hesiod, nor even in the Batrachomyomachia. It was, however, a common domestic animal in Egypt in the days of Herodotus.

The ePIAAKA of Alcman, Hipponax, Herodotus, and Athenæus iii. 82 , according to the received opinion and Greek usage, is the lettuce (Lactuca sativa).-At the present day, the lettuce is very generally cultivated throughout the Arab countries.

In Egypt, the Sesamum Orientale is called "semsem ;" and in this

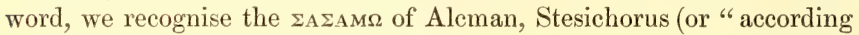
to some Ibycus"), Crates, and Athenæus iii. 75 and iv. 72.-Herodotus speaks of the sesamum and its oil, in his account of the Euphrates; and Pliny alludes to the presence of the plant in Egypt; where at the present day, it is abundantly cultivated. Forskal met with the sesamum as far North as the island of Tenedos.

In Egypt, the Calendula arvensis is called "kahleh;" and in this word, we recognise the KAגXAN of Alcman, Epicharmus, Nicolaus Damascenus, and Athenæus xv. 28.-Delile found the C. arvensis growing spontaneously around Cairo; and the $C$. officinalis, in gardens at Alexandria.

The coronary E $\Lambda$ IXPY $\Omega$ of Alcman, Ibycus, Cratinus, Themistagoras, and Athenæus xv. 27, is usually referred to the Gnaphalium stoechas.This plant was seen by Delile at Alexandria, but apparently indigenous. 
From Dioscorides' account of the "melanthion," the MAKoni $\Delta \Omega \mathrm{N}$ APTSN of Alcman and Athenæus iii. 75, would seem to be, bread sprinkled with the black seeds of Nigella sativa; according to the custom in Egypt at the present day. This custom is also noticed by Pliny and Belon.

According to Theophrastus and Greek records consulted by Pliny. The $\Sigma I \Lambda \Phi I O N$ was discovered seven years before the founding of Cyrene (or about B. C. 638).-The concrete juice of this plant was much used in Ancient Greek cookery; but at the present day, is nearly unknown, The plant, however (agreeing with the figures on ancient coins), has been re-discovered in the same district of North Africa by P. della Cella; and has received the name of Thapsia silphium.

The name of Neku or Nechoh, the fifth king of the Twenty-Sixth Egyptian Dynasty, has been found at Rosetta; and on various stelæ; together with the date of the fourth year of his reign. Neku captured Jerusalem (2 Kings xxiii., 2 Chronicles xxxv., and Herodotus ii. 159) in the course of his great military expedition; which is described in burning words in Jeremiah xlvi. The reign of Neku is also remarkable for the first Circumnavigation of Africa (see Herodotus iv. 40).

The "bryt" of Jeremiah ii. 22, and Malachi iii. 2, may be compared with "ryteh," the current Egyptian name of the fruit of Sapindus laurifolius.-According to Forskal and Delile, this imported fruit is employed in washing the finer kinds of woollens: and according to Graham, the tree grows in Hindostan.

The $\odot$ A $\Omega$ of Sappho, Aristophanes (Vesp. 1404), and Theocritus ii. 88 , is referred by the Scholiast of Theocritus to the "chrysoxylon" of the Modern Greeks, Rhus cotinus.-This, shrub, according to Sibthorp and others, is indigenous on the mountains of Greece; and as the wood is still used for dyeing at Athens, it cannot be altogether unknown in Egypt.

The annits of Sappho, Alcæus, Aristophanes, Theophrastus, Dioscorides, and Athenæus xv. 16, is referred by Sibthorp and others to the dill (Anethum graveolens).-Forskal, Delile, and Clot-Bey, speak of the cultivation of the A. graveolens in Egypt.

The name of Psamtik II., the sixth king of the Twenty-Sixth Egyptian Dynasty, has been found on stones, once part of a propylon at Memphis ; on a sarcophagus, at the bottom of the remarkably insulated pit discovered by Vyse at Gizeh; in tombs at Sakhara; on stones employed in reparations at Thebes; on the rocks near Philæ; 
on an obelisk, now at Rome; and on movable articles, now in the museums of Europe; together with the date of the fourth year of his reign.

In one instance, the oval including the hieroglyphic name of King Psamtik II., is accompanied with an inscription in Assyrian, or cuneiform writing.

The name of Hophra, the seventh king of the Twenty-Sixth Egyptian Dynasty, has been found on the rocks near Philæ; on stones employed in building the citadel at Cairo; on an obelisk, now at Rome; and on movable articles, now in the museums of Europe. King Hophra is mentioned in Jeremiah xliv. 30. He is the Apries of Herodotus.

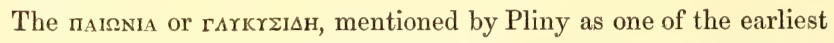
known medicinal plants, and noticed also in the Hippocratic writings (De superf. 20, and De mul. morb. 56), and by Theophrastus, Dioscorides, and Paulus Fgineta, is admitted to be one or more species of peony (Pæonia).-Alpinus and Forskal (Mat. Med.) speak of the medicinal use in Egypt of "pæonia" roots and seeds: and the P. officinalis and $\mathrm{P}$. corallina were seen by Sibthorp, indigenous on the mountains of Greece.

The A*INeI $\Omega$, mentioned by Pliny xxvii. 28, as known to the Romans from the earliest times, and noticed also by Euripedes, Theophrastus, Diphilus, Dioscorides, and Athenæus iv. 9, is admitted to be the Artemisia absinthium. - Forskal enumerates "melh afsantin" among the articles of the Egyptian materia medica; and according to Clot-Bey and Figari, the living plant has been long known in Egypt.

In "B. C. 569" (Clinton), the accession of Aahmes or Amasis, the eighth king of the Twenty-Sixth Egyptian Dynasty, took place. His name has been found at Elephantine; on the rocks near Philæ; on stones employed in building the citadel at Cairo; and on various movable articles now in the museums of Europe: among the accompanying dates, one is in the forty-fourth year of his reign. The first introduction of Greek architecture into Egypt, is perhaps to be referred to the reign of Aahmes: for he permitted the Greeks to build a temple at Naucratis, near one of the mouths of the Nile. He also put an end to the independence of Cyprus (Herodotus ii. 178 and 182).

According to Herodotus iii. 47, Aahmes sent to Greece a cuirass composed partly of "eirioisi apo xylo," or cotton (Gossypium).-The "krps" of Esther i. 6, may also be compared with "karpas," given 
by D'Rozario as the Bengali name of cotton : and Herodotus, in another place (iii. 106), speaks of a "tree growing in India, which instead of fruit produces wool, out of which the inhabitants make their clothes." Some centuries later, as appears from Pliny and others, the living plant was introduced into Egypt.

Jao de Sousa* enumerates the ingredients used by the Arab settlers of Spain and Portugal in composing the "bachur" ointment: in the name, we recognise the BAKXAPIz of Hipponax, Simonides, Eschylus, Ion, Achæus, Epilycus, Cephisodorus, and Athenæus xv. 40.

The коккомндом of Hipponax, Aristophanes, and Theophrastus, according to the received opinion and Sibthorp's account of the Greek usage, is the garden plum (Prunus domestica).-Theophrastus likewise mentions the plum under the name of "proyne:" at the present day, several varieties of the plum are cultivated in Egypt; though according to Clot-Bey and Figari, the fruit is of inferior quality.

The мімөн of Hipponax, Theophrastus, and others, according to the received opinion and Scarlatus' account of the Greek usage, is one or more species of mint (Mentha).-The M. glabrata and M. sativa, were seen by Delile in gardens at Cairo.

The Padanoz of Hipponax, Ananias, and Epicharmus, is referred by Athenæus and others to the "krambe" of the Batrachomyomachia, Timæus, Apollodorus Carystius, and Nicander; the "koroumb" of modern Egypt, or the cabbage (Brassica oleracea).-The "goggylis" of Aristophanes and others, may be compared with the turnip-rooted variety. At the time of Alpinus' visit, only two varieties of the cabbage were known in Egypt, the "brassica raposa" and the cauliflower. In "karnabid," the Egyptian name of the cauliflower, we recognise the "karnabadion" of Florentinus and the Geoponica ix. 28, and the "koynoypidi" of the modern Greeks.

In Egypt, the squill (Scilla maritima) is called "askyl;" in which word, we recognise the "skilla" of Pythagoras (as quoted by Pliny xix: 30), and of Theognis 537, and other Greek writers. Fresh bulbs of the S. maritima, were brought from the Desert to Delile at Alexandria.

According to Pliny xx. 87, Pythagoras commended the penetrating power of the "sinapi;" usually referred, together with the "napy" of Aristophanes and Theophrastus, to the mustard.-Pliny further alludes

* Jao de Sousa, Vestig. Arab. Lisbon, 1789. 
to the presence of the plant in Egypt; and the Sinapis juncea was seen there by Delile in cultivated fields. The S. alba and S. nigra were seen by Sibthorp in Greece; but according to Clot-Bey and Figari, have been only recently introduced into Egypt.

In Egypt, the anise (Pimpinella anisum) is called "yansoun;" in which word, we recognise the "anison" of Pythagoras (as quoted by Pliny), of some of the writings attributed to Hippocrates, and of Dioscorides iii. 58.-Pliny expressly alludes to the presence of the plant in Egypt.

In "B. C. 526" (Clinton i. p. 236), the accession of Psamtik III., the ninth king of the Twenty-Sixth Egyptian Dynasty, took place. His name has been found on the monuments, although his reign lasted only a few months.

In "B. C. 525" (Clinton), the Persians under Kembath or Cambyses obtained possession of Egypt. Kembath thus became the head of a new Egyptian Dynasty; and his name has been found in hieroglyphic characters on the monuments; together with the date of the sixth year of his reign.

In "B. C. 521," * the accession of Nteriusch or Darius, the second Persian king who ruled Egypt, took place. His name has been found in hieroglyphic characters on rocks on the Kosser road; and on temples at the Oasis el Khargeh and the Oasis of Ammon : among the accompanying dates, one is in the thirty-sixth year of his reign. The first coined money used in Egypt, appears to have been, the well-known "dariks" issued by Darius.

The комrzн of Hecatæus and Athenæus x. 67 (the flower of which, according to Horapollo, formed one of the hieroglyphic characters), may be compared with the Conyza Dioscoridis:-A plant seen by Rauwolf in Palestine; and by Forskal and Delile, growing spontaneously at Rosetta, Damietta, and Cairo. The C. Agyptiaca was also seen by Forskal and Delile, growing spontaneously at Cairo.

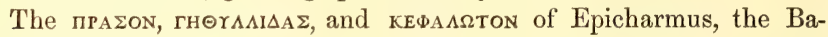
trachomyomachia, Eubulus, Theophrastus, Diphilus, Polemon, Epænetus, and Athenæus ix. 13, are usually referred to the leek (Allium porrum.) $\dagger$ The "krommya karta kaloymena" of Galen (equivalent

* In the following pages, the dates of the accession of kings, are taken from Clinton (unless otherwise specified) as far as the commencement of the Muslim Period; and in after-times, from the work entitled, L'Art de Verifier des Dates.

+ There is, however, a closely allied species (Allium ampeloprasum) in the Grecian 
to the "porrum sectivum" of Pliny), may also be compared with the Hebrew verb "krt," and with "kourat," the current Egyptian name of the leek.

The MAPA@ON of Epicharmus, Archestratus, Demosthenes, and Athenæus ii. 47 and 83, according to the received opinion and Sibthorp's account of the Greek usage, is the fennel (Fœeniculum vulgare).-Clot-Bey and Figari enumerate the fennel among the plants long known in Egypt.

In Egypt, the garden-basil (Ocymum basilicum) is called "ryhan;" in which word we recognise, the opIranon of Epicharmus, Ion, Aristophanes, Athenæus ii. 77, and the Modern Greeks. The field culture of the garden-basil in Egypt is mentioned by Belon. The genus Ocymum appears to be strictly Tropical, and of course, foreign originally to the Mediterranean countries.

The serisA of Epicharmus (quoted by Athenæus ii. 83), according to the received opinion, is the endive (Cichorium endivia).-This plant is well known in Egypt; as also, the closely allied succory (C. intybus): and Pliny's statement (xix, 39), that the "erraticum intubum" or succory is called "chichorium" in Egypt, is found to be true at the present day.

The Iøron (above mentioned) of Epicharmus, Theophrastus vi. 6, and Athenæus ii. 83, may also be compared with the "phoy" of Dioscorides and Pliny; referred by Sibthorp to the Valeriana Dioscoridis: and the "keltike nardos" of Nicander, Andromachus, Dioscorides, and Macer Floridus 75, is considered to be the V. Celtica. It would seem, therefore, that valerian roots, procured on the wild mountains of Europe, already formed an article of commerce with Egypt.-Where, according to Alpinus, they are still used for medicinal purposes.

The $\triangle A \Pi A \odot O N$ of Epicharmus, Theophrastus, Diocles, Pliny, and Athenæus ii. 57 and 83, according to the received opinion, is the Rumex patientia.-A plant regularly cultivated in Europe; and seen by Sibthorp in Greece; and from being apparently noticed by Athenæus, perhaps once known in Egypt.

The кıгsos, or ivy (Hedera), a plant connected with the worship of Bacchus, is mentioned by Pratinas, Pindar, Sophocles, Semus Delius, and Athenæus xiv. 16. The ivy is generally considered to be indi-

Archipelago; where, from Sibthorp's account, it would seem to be indigenous; but it has not hitherto been observed in Egypt. 
genous in Europe; but this is not altogether certain.-Arrian states, that Alexander met with priests of Bacchus on the Upper Indus, who informed him, That the ivy in that quarter grew only upon Mount Meros. Hasselquist found the ivy on Mount Tabor; and I have been informed, of some recent unsuccessful attempts to cultivate the plant in Egypt.

The sEALOz of Eschylus and Pindar (Pyth. ii.), is referred by Theodorus Gaza and others to the cork-tree (Quercus suber).-This species of oak grows in Italy (as remarked by Theophrastus iii. 16); and also, in Spain; but was not seen by Sibthorp in Greece. The economical uses of the bark, were doubtless communicated to Egypt at an early period.

The enathrion of Eschylus (Choeph. 962), Hippocrates, Theophrastus ix. 14, and Dioscorides, is considered to be the drug obtained from the Momordica elaterium.-The plant was seen by Sibthorp in Greece; and was received from Egypt by Linnæus.

The IEAINON KHIAAION of Pindar, Aristophanes, and Dioscorides, translated "apium" by Cato, Virgil, and Pliny, seems to correspond with the parsley (Petroselinum sativum).-The parsley was seen by Forskal and Delile in gardens at Cairo; but according to Clot-Bey and Figari, is rare in Egypt.

The KAAAMIN@H of the Batrachomyomachia, Aristophanes, and Dioscorides, according to Sibthorp's account of the Greek usage, would seem to be the Mentha sylvestris.-This plant was seen by Forskal and Delile, growing spontaneously at Rosetta.

In "B. C. 485," the accession of Cheschearscha or Xerxes, the third Persian king who ruled Egypt, took place. His name has been found in hieroglyphic characters on rocks on the Kosser road; and on movable articles, now in the museums of Europe; together with the date of the twelfth year of his reign.

In "B. C. 480," Xerxes set out from Sardis, in Asia Minor, on his memorable invasion of Greece.

The earliest Greek coins hitherto discovered, are those issued by Alexander I., the Macedonian king who accompanied the army of Xerxes. The letters on them, are the Greek capital letters used at the present day.

Statues holding the "fruit of the garden-pine," the work of Ptolichus and Calamis, were seen by Pausanias.-Pine-nuts are mentioned by Mnesitheus, Theophrastus, Diocles, Alexander Myndius, Nicander, 
Virgil, and Galen (De Aliment. Fac. ii.); and their importation into Egypt, is noticed by Athenæus. But the living tree (Pinus pinea), appears to have remained unknown in Palestine and Egypt.

The eрпrлало of Cratinus, Eubulus, Antiphanes, Theophrastus vi. 1, and Athenæus xv. 32 and xii. 78, is usually referred to the thyme (Thymus serpyllum). - This plant readily becomes naturalized in foreign countries ; but except in being apparently known to Athenæus, I have met with no evidence of its presence in Egypt.

The paфaniz of Cratinus, Pherecrates, Eupolis, Aristophanes, Amphis, and Athenæus, according to Sibthorp's account of the Greek usage, would seem to be the charlock (Raphanus raphanistrum).F. Columna found this plant eaten in Apulia : and an allied species occurs in Egypt; where, too, the leaves of the R. sativus are eaten. The "R. sativus, var. oleifer" was seen by Lippi, cultivated in Nubia; and by Granger, in Egypt.

It seems probable, however, that the "Egyptian raphaninum oleum" of Pliny was obtained from the coleseed or rape (Brassica napus). Galen (De Fac. Alim. ii. p. 622) does not distinguish the "raphanidas" from the "boyniadas:" and according to Clot-Bey, the manufacture of rape-seed oil is at the present day well known in Egypt.

The нмерокаAлEI of Cratinus (as quoted by Athenæus xv. 28), according to the description by Theophrastus vi. 1, and Sibthorp's account of the Greek usage, would seem to be one or more species of Dephne.-These are low shrubs of the Northern shores of the Mediterranean, which appear to be unknown in Egypt in the living state; but their medicinal uses are mentioned by Arab writers.

The hmeroka clearly a different plant; and is referred by Sibthorp to the Lilium Chalcedonicum.-This plant was seen by Sibthorp, wild on the mountains of Greece, and may have been known in Egypt to Athenæus. The $L$. martagon, also found by Sibthorp wild on the mountains of Greece; was seen by Belon at Constantinople; and has been long cultivated in the gardens of Europe; but I have met with no evidence of its being known in Egypt.

The asmaparoz of Cratinus, Pherecrates, Ameipsias, Theopompus, Theophrastus, and Athenæus ii. 62, according to the received opinion and Scarlatus' account of the Greek usage, is the garden asparagus (A. officinalis).-Cato, as quoted by Pliny, gives directions respecting the culture of the "asparagus."-And our garden asparagus is enumerated by Alpinus in his list of the esculent plants of Egypt. 
The ANEM $\Omega$ NH of Cratinus, and the "phlogion" of Theophrastus and Pliny, may be compared with the species of Adonis.-Horapollo states, that the flower of the "anemone" forms a hieroglyphic character: and the Adonis æstivalis and an indigenous species, were seen by Delile in Egypt; where, on the other hand, the modern genus Anemone appears to be unknown.

The меліллтог of Cratinus, Aristotle, and others, is usually referred to the Melilotus officinalis; and the brief notice by Theophrastus (De Caussis Plant. vi. 22) corresponds.-The M. officinalis was seen by Sibthorp in Greece; and by Clot-Bey and Figari, in Egypt : and allied species, the $M$. Messanensis and $M$. Cretica, were seen by Delile, growing spontaneously at Alexandria, Rosetta, Damietta, and Cairo.

In "B. C. 465," the accession of Artabanus, the fourth Persian king who ruled Egypt, took place. In the same year, he was succeeded by Artcheschsesch, or Artaxerxes; whose name in hieroglyphic characters has been found on rocks on the Kosser road; and on other monuments ; together with the date of the sixteenth year of his reign.

In Yemen, according to Forskal, the Panicum mitiaceum is called "milæh:" the MEAINH of Sophocles, Herodotus iii. 117, Xenophon (Anab. i. 5, 10), and Harpocration, may be compared.-The P. miliaceum is a species of millet, described as having a spreading panicle, and said to be sometimes cultivated in Europe. It was seen by Hasselquist in Palestine; and by Forskal, in Egypt.

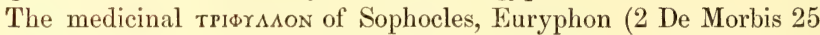
and 38), Nicander, Dioscorides, and Pliny xxi. 88, is referred by Sibthorp and others to the Psoralea bituminosa.-This plant has not been found in Egypt; but an allied species, P. Pulcestina, was seen by Delile in a garden at Cairo.

The акалөн of Sophocles (quoted by Plutarch, Disput. de Epicur. 19) is clearly a thistle.-Various kinds of thistles have been found in Egypt: as the Onopordum Grocum, seen by Sibthorp in Greece and Cyprus; and by Delile, growing spontaneously at Alexandria.

Hellanicus (as quoted by Athenæus xv. 24) speaks of the AKAN@AI AEYKAI, and MEAANAI being used for garlands in Egypt.-The Centaurea moschata, seen in gardens at Cairo, is enumerated by Forskal among the coronary plants.

The pamnoz of Sophron, Eupolis, Theophrastus, Euphorion, and Macrobius (Saturn. vii. 5), according to the received opinion and Sibthorp's account of the Greek usage, is the Lycium Europaum.-This 
plant was seen by Hasselquist at Jerusalem; and by Forskal, Delile, and others, growing spontaneously at Alexandria and Damietta.

Herodotus iv. 53, speaks of the sturgeon of the large rivers of Southern Russia; and of its flesh being dried or salted.-Fish-glue or isinglass, "ichthyocolla," is described by Dioscorides, Pliny xxxii. 24, and Alian.

The drug castor (obtained from the beaver of the North), is mentioned by Herodotus iv. 109; and is more particularly noticed by Celsus, Dioscorides, and Galen.-Its importation into Egypt is shown, by the drug being recommended by Serapion, Rhazes, Avicenna, and other Arab medical writers.

The Kannabis, mentioned by Herodotus (iv. 74) as a plant used by the Scythians for making cloth, is admitted to be the hemp (Cannabis sativa).-This plant is cultivated in Egypt solely for its intoxicating properties; which have been known there (according to Lane) for about six centuries.

Herodotus iii. 98, Megasthenes, and Strabo xv., speak of the bamboo (Bambos arundinacea) as a production of India.-The living plant appears to have remained unknown in Egypt until within a few years; but according to Clot-Bey and Figari, is now cultivated there with success.

Herodotus describes the edible Nymphrea lotus ; and, as abounding in Egypt. - Theophrastus also mentions the "white-flowered Egyptian lotus." I did not meet with the N. lotus in Egypt; but was informed, that it makes its appearance after the inundation.

In Egypt, certain downy-leaved plants, including the Croton tinctorium, are called "ghobbeyreh;" a word which seems to indicate the

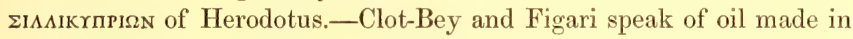
Egypt from seeds of the C. tinctorium. The plant however does not appear to be cultivated; but grows as a weed, as observed by myself in the Thebaid. It occurs also on the Northern shores of the Mediterranean, according to Camerarius, Tournefort, and Sibthorp.

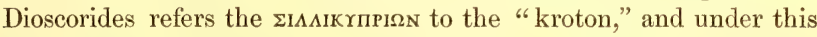
name distinctly describes the castor-oil plant (Ricinus communis); Sibthorp's account of the Greek usage seems also to correspond.The "kroton" is mentioned in the Hippocratic writings (De Nat. Mul. and 2 De Mul. Morb. 79), and by Theophrastus and Nicander (Ther. 676). Pliny speaks of the presence of the "croton" or "ricinus" in Egypt: where at the present day, the R. communis is well known. 
This plant was doubtless introduced from Hindostan, or perhaps, originally from the Malay countries.

The sxinos of Herodotus, Theophrastus, and others, according to the received opinion and Sibthorp's account of the Greek usage, is the mastich-tree (Pistacia lentiscus).-Mastich is mentioned by Dioscorides and Pliny, and Paulus Egineta speaks of an Egyptian kind; but the living tree appears to be unknown in Egypt.

In Egypt, gum ladanum (the product of one or more indigenous species of Cistus) is called "laden;" in which word we recognise, the " $\triangle \mathrm{H} \triangle \mathrm{ANON}$ procured by the Arabians" of Herodotus iii. 107.Pliny states, that "ladanum" is produced in the Nabathæan district, and in Cyprus; but at the present day, according to Forskal (Mat. Med.), this gum is imported into Egypt from Crete.

Gum-arabic, the product of Acacia gummifera, is mentioned by Herodotus and Pliny.-A small quantity is known to be procured in the Sinai Peninsula; but the principal source of the gum-arabic of commerce, is the Somali country. The living tree was seen by Delile in Upper Egypt: I did not meet with it; nor with any wild Acacia in Egypt that exceeded the dimensions of a shrub.

The Virgil (Geor. ii. 117), or frankincense-wood, are referred by Sprengel to the Amyris kafal.-This tree grows in Yemen; and according to Forskal, its wood is exported in large quantities to Egypt.

The өrмвpa of Euripides (Rhes. 508), Aristophanes, Demochares, Theophrastus, and Athenæus v. 12, according to Tournefort's and Sibthorp's account of the Greek usage, is the Satureja thymbra.-This plant is indigenous in the Grecian Archipelago; and being noticed by Athenæus, was probably once known in Egypt.

The coronary minaz of Euripides, Pherecrates, Aristophanes, and Athenæus, according to the received opinion, is the Smilax aspera: which is said to have odorous flowers.-Callixenus speaks of branches, used in the festival of Ptolemy Philadelphus; doubtless imported; for the Smilax being a woodland plant, is of course unknown in Egypt.

The en@przkon of Pherecrates, Theophrastus, Columella, and Dioscorides, is referred by C. Bauhin to the Chorophyllum sativum.-Pliny xxi. 52, enumerates the "anthriscum" among the esculent plants of Egypt: and the C. sativum, was seen by Forskal and Delile in gardens at Cairo. 
In "B. C. 425," the accession of Xerxes II., the sixth Persian king who ruled Egypt, took place. His reign was brief; and in the same year, he was succeeded by Sogdianus.

In "B. C. 424," the accession of Nteriusch II., or Darius II., the eighth Persian king who ruled Egypt, took place. His name has been found in hieroglyphic characters on the monuments.

The mizon of Eupolis, Aristophanes, Antiphanes, Theophrastus, Pliny, and Athenæus ix. 71 and 10, according to the received opinion, is the garden-pea (Pisum sativum).-Alpinus enumerates the gardenpea in his list of the esculent plants of Egypt.

The фцомог of Eupolis, Aristotle viii., Dioscorides, and Macrobius, according to the received opinion and Sibthorp's account of the Greek usage, is one or more species of mullein (Verbascum).-The V. sinuatum was seen in Egypt by Delile, and by Clot-Bey and Figari.

In "B. C. 414" (Clinton), the Egyptians recovered their independence. Their leader Amyrtæus, or Meritetnacht, is regarded as the sole king of the Twenty-Eighth Dynasty : and his name has been found in hieroglyphic characters on the monuments.

As the reign of Amyrtæus is said to have lasted only "six years," Clinton's computation will give B. C. 408 for the accession of Nepherites, the first king of the Twenty-Ninth Egyptian Dynasty. Nepherites is also mentioned by Diodorus xiv. 79 .

The корıг of Aristophanes (Nub. 630), according to the received opinion, is the Cimex lectularius.-The "cimex" of Catullus and Pliny, and the "lectuli bestias" of Tertullian (Adv. Marcion i. 14), may also be referred to this insect: which, at the present day, is well known in Egypt.

According to Athenæus ix. 37, the pheasant (Phasianus Colchicus) is mentioned by Aristophanes, Epænetus, Mnesimachus, and Agatharchides Cnidius.-Callixenus states, that pheasants were carried at Alexandria in the festival of Ptolemy Philadelphus.

The pisYpa of Aristophanes, Xenarchus, and Athenæus xii. 76 and $\mathrm{xv} .24$, according to the received opinion and Sibthorp's account of the Greek usage, is the linden (Tilia Europæa). - Forskal mentions the importation of timber of the linden into Egypt.

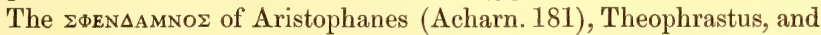
others, according to the received opinion, is one or more species of maple (Acer). - The A. campestre, is enumerated by Clot-Bey and Figari, among the trees planted in gardens at Cairo. 
The вАнтол ог вАIтоN of Aristophanes, Theophrastus, Dioscorides, and Palladius, according to the received opinion and Sibthorp's account of the Greek usage, is the Amaranthus blitum.-This plant is still cultivated in Europe as an esculent; and, according to Alpinus, also in Egypt.

The гоггхмг (already mentioned) of Aristophanes, Theophrastus i. 9, Diocles, Columella, Athenæus, and Aretæus, and the "rapum" of Cato and Pliny, are referred by Beckmann to the turnip (Brassica rapa).-The cultivation of the turnip in Syria and Egypt is noticed by various modern travellers.

The KarAamon of Aristophanes, the Hippocratic writings, and Polyænus, according to Sibthorp's account of the Greek usage, is the Lepidium sativum, or pepper-grass.-The L. sativum is enumerated by Forskal, Delile, and others, among the plants cultivated in Egypt.

In Egypt, the field-pea (Pisum arvense) is called "besilleh;" in which word we recognise, the "piseli" of the modern Greeks; and ap-

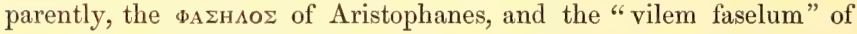
Virgil.

The волвог of Aristophanes (Nub. 188), Archestratus, Xenarchus, Heraclides Tarentinus, Theophrastus vii. 2, and Athenæus ii. 64, according to Sibthorp's account of the Greek usage, is the Muscari comosum.-This plant was seen by Delile, growing spontaneously at Alexandria.

The фүког of Aristophanes (Thesm. 2), Theophrastus, Dioscorides, and Pliny, is referred by Tournefort and Dillenius to the argol or archil (Lichen rocella).-Tournefort met with this lichen in the Grecian Archipelago, and speaks of its exportation, both to England and Egypt.

The nhranon of Aristophanes, Cytherius Philoxenus, Aristophon, Dioscorides, and Athenæus ii. 62 and xiv. 50, according to the received opinion and Sibthorp's account of the Greek usage, is one or more species of rue (Ruta).- The R. Chalepensis, was seen by Delile and others in gardens at Cairo; and both this and the R. graveolens, are enumerated by Clot-Bey and Figari among the plants long known in Egypt.

The АКААнФн of Aristophanes, Diocles, and Athenæus ii. 57, according to the received opinion, is one or more species of nettle (Urtica).The U. pilulifera, was seen by Forskal and Delile, growing spontaneously at Cairo; the $U$. urens was also seen by Delile, growing spontaneously at Cairo; and the U. dioica was seen in Egypt by Hasselquist.

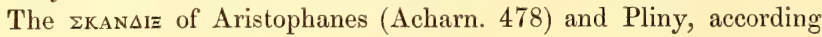


to the received opinion and Sibthorp's account of the Greek usage, is one or more species of Scandix.-The S. trichosperma was received from Egypt by Linnæus.

The гxorzA of Aristophanes (Eccles. 929 and Lysistrat. 48), Theophrastus vii. 9, Nicander (Ther. 838), and Dioscorides, clearly corresponds with the Echium rubrum of Forskal.-Forskal found this plant still used as a cosmetic in Egypt.

The аморгілог of Aristophanes (Lysistrat. 735), according to Sibthorp's and Scarlatus' account of the Greek usage, would seem to be the Scorpiurus sulcata. - This plant was found by Delile along the borders of the cultivated fields of Lower Egypt; and the S. villosa was seen by Forskal growing spontaneously at Cairo.

The ๑rmon of Aristophanes, Theophrastus, Ariston, Hegesander, and Athenæus ii. 60, according to Tournefort's and Sibthorp's account of the Greek usage, is the Satureja? capitata.-This plant abounds in the Grecian Archipelago; and was seen by Delile, indigenous near Alexandria.

The endebopos of Aristophanes, Euryphon, Demosthenes, Theophrastus, Dioscorides, and Oribasius, is considered to be the Helleborus Orientalis; an indigenous plant of Greece.-Two kinds, however, are mentioned by ancient writers; and Forskal (Mat. Med.) notices the importation and medical use in Egypt of roots of the " $h$. niger and h. albus."

The карта поNтіка of Ctesias, Dioscorides, and Athenæus, according to Forskal's account of the usage at Constantinople, is the filbert (Corylus avellana). - Virgil enumerates the filbert among cultivated plants; and Pliny states (xv. 24), that it was brought into Greece and Asia Minor from Pontus. The living plant appears to be unknown in Egypt.

Ctesias speaks of a bird in India that "could talk like man, and even speak Greek, if it had learned the language ;" and in this description, we readily recognise the parrot (Psittacus). At this time, therefore, the parrot was unknown in Greece; but the bird must have been introduced shortly afterwards, for it is mentioned by Aristotle, Ovid, and Pliny.

As the above-described parrot was partly "of the colour of KINNABAP," it would seem, that Ctesias referred to our modern cinnabar, or vermilion (the sulphuret of quicksilver). - Crude quicksilver, 
"ydrargyros," is mentioned by Aristotle, Vitruvius, Dioscorides, Pliny, and Galen; and also by the Arab medical writers.

Pliny xxxiii. 38, remarks, that KINNABAP is an Indian word, and is applied to "saniem draconis," or dragon's blood (said to be the product of Dracæna draco): and he further speaks of serious mistakes in the practice of medicine, arising from this confusion of names.-The medicinal use of dragon's blood, is also mentioned by Paulus Egineta, Constantinus, and the Arab writers.

The man $\triangle$ PaTopor of the treatise " 2 De Morbis" (quoted by Galen as a work of Euryphon), and of Demosthenes 133, 1, Theophrastus, and Dioscorides, according to the received opinion and Sibthorp's account of the Greek usage, is the Atropa mandragora.-This is an indigenous plant of Greece and other parts of Europe; and Forskal (Mat. Med.) notices the medicinal use in Egypt of the imported roots.

The Ainoz $\Omega$ sis of Euryphon (2 De Morbis 12 and 77), Dioscorides, and Pliny, and the "herba mercurialis" mentioned by Cato as both esculent and medicinal, are usually referred to one or more species of Mercurialis. - The M. annua was seen by Sibthorp in Greece; by Hasselquist in Palestine; and by Delile, growing spontaneously at Alexandria.

The rIEPIKon of Euryphon (2 De Morb. 52 and 62), Nicander (Alex. 616), and Dioscorides, according to Sibthorp's account of the Greek usage, would seem to be the Hypericum crispum.-Plants of this genus have not been found growing in Egypt; but a species is imported for medicinal use, as appears from Alpinus and the Materia Medica of Forskal.

In Egypt, the Erythroea centaurium is called "kantarian ;" in which word we recognise, the Kentarpion of Euryphon (2 De Morb. 52), Theophrastus, Lucretius ii. 401, and Celsus.-Forskal speaks of the medicinal use in Egypt of the E. centaurium; seen by him growing spontaneously at Cairo.

The mentaфrasor pizsn of Euryphon (2 De Morb. 38), Theophrastus, Celsus vi. 18, and Dioscorides, according to the received opinion and Sibthorp's account of the Greek usage, is the Potentilla reptans.Alpinus and Forskal (Mat. Med.) speak of the medicinal use in Egypt of "pentaphyllum" root. An allied species, $P$. supina, was seen by Forskal and Delile, growing spontaneously at Cairo; doubtless by some means introduced.

The Актн of Euryphon (2 De Morb. 19), Theophrastus, and Dios- 
corides, is referred by Sibthorp and others to the Sambucus nigra.This plant is enumerated by Clot-Bey and Figari among those long known in Egypt.

The pors of Euryphon (2 De Morb. 28), Theophrastus, Dioscorides, and Pliny, is referred by Sibthorp and others to the Rhus coriaria.This shrub was seen in Palestine by Pococke and Rabbi Schwarz; and Delile mentions the medicinal use of the imported berries in Egypt.

In Egypt, the Origanum Egyptiacum is called "mardakusj;" in which word we recognise, the amapakos of Chæremon, Eubulus, Diocles, and Athenæus xiii. 87 and xii. 78.-The O. Egyptiacum was seen by Delile in gardens at Cairo; and the $O$. majorana, was seen in Egypt by Hasselquist.

According to Gesenius and Gliddon (Otia Egyp., p. 106), no Phoenician or Punic inscription hitherto discovered, has proved to be earlier than B. C. 394.-The Samaritan letters, and those on the Maccabee coins, are regarded as directly descended from the Phøenician.

The name of Hakor, or Acoris, the second king of the TwentyNinth Egyptian Dynasty, has been found on repaired portions of the temples at Medinet-Habu and El Kab; in the quarries at Tura, accompanied by the date of the second year of his reign; and on a sphinx now in the museum at Paris. King Acoris is mentioned by Theopompus and Diodorus.

The roskramoz of Xenophon (Econ. i. 13), Dioscorides, and Paulus Agineta, according to the received opinion and Sibthorp's account of the Greek usage, is one or more species of Hyoscyamus,-The $\mathrm{H}$. albus was seen by Delile, growing spontaneously at Alexandria; and in the Desert, I repeatedly met with the indigenous $\mathrm{H}$. datura.

The IPIs, entering into the composition of the IPINON MYPON of Cephisodorus, Didymus, and Athenæus xii. 78 and xv. 39, and stated by Theophrastus to be "the only spice which Europe produces," is admitted to be orris-root (Iris Florentina). - This plant was seen by Hawkins and Sibthorp in Greece; and the imported roots are doubtless known in Egypt.

The $\Omega$ KIM $\Omega$ N of Strattis, Theophrastus, Cato, and Athenæus ii. 79, according to Sibthorp's and Scarlatus' account of the Greek usage, would seem to be the Reseda phyteuma.-Sibthorp found the leaves of this plant cooked and eaten in Greece. Forskal names the plant, as 
seen by him in the Desert near Cairo; but some doubt in regard to the species, is expressed by Delile.

According to Theopompus (fr. 111) and C. Muller, The accession of Nechtneb or Nectanebus, the first king of the Thirtieth Egyptian Dynasty, took place prior to B. C. 376 . His name has been found by Champollion, on small temples at Medinet-Habu and Philæ; on stones employed in building the citadel at Cairo, and the Coptic church at Keft; and on movable articles, now in the museums of Europe.

According to Birch, The earliest Zodiacal projection observed on a sarcophagus, is of the time of King Nectanebus.

Athenæus ii. 73 (after noticing the silence of Ctesias on the subject), refers to Eubulus and Antiphanes as the earliest writers who speak of the пепЕPI, or black pepper.-The пЕпеPI, is mentioned in the treatise "De Vict. Acut." (considered as a genuine work of Hippocrates); and was of course imported from India; or, perhaps, through India from the Malay countries. I saw in the Thebaid, a quantity of black pepper that had been imported by the way of Mecca.

The exaneemon of Hippocrates, Asclepiades, and Pliny, referred by Galen to the "chamaimelon," appears to be the true chamomile (Anthemis nobilis). - Macer Floridus mentions chamomile flowers; and Alpinus speaks of their medicinal use in Egypt; where the living plant, according to Clot-Bey and Figari, has been only recently introduced.

The аммі of Hippocrates (as quoted by Pliny), and of Dioscorides and Paulus Agineta, is referred by Sprengel to the Ptychotis ajowan; so abundantly cultivated, for the sake of its seeds, in Hindostan. Forskal (Mat. Med.) speaks of the importation of "ammi" seeds from India ; and also states, that some are produced in Egypt.

The пеплion of Hippocrates (referred by Dioscorides iv. 150 to the

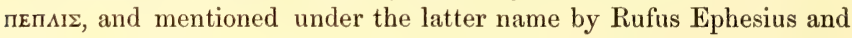
Galen), according to the received opinion, is the Euphorbia peplis. This plant was seen by Delile, growing spontaneously at Alexandria.

The err@Po $A$ ANON of Hippocrates (De Vict. Acut.), Theophrastus, and Dioscorides, according to the received opinion, is the madder; mentioned also by Philon Judæus (Quis rer. Divin. Heres) under its well-known Egyptian name, "phoya." Some of the mummy cloths are said to be dyed with madder; imported, perhaps, as in modern times, from the island of Cyprus. - The madder plant (Rubia tinctorum) was seen by Delile in gardens at Damietta; but according to 
Clot-Bey and Figari, its field culture has been only recently practised in Egypt.

The IEEEAI of Hippocrates (De Vict. Acut. 12), may be compared with the "pimpinella," enumerated by Forskal (Mat. Med.) as imported and used medicinally in Egypt.*

In Egypt, according to Forskal, the Vicia lutea is called "bachra;" in which word we recognise, the $\Omega$ xpos of Anaxandrides, Alexis, Phanias, Theophrastus, and Athenæus ii. 44 and iv. 7.

The AA@rpoz of Anaxandrides, Alexis, Theophrastus, and Athenæus ii. 44 and iv. 7, may be compared with the Lathyrus sativus.-This plant was seen in Upper Egypt by Delile; and Clot-Bey and Figari state, that it is "cultivated there, and the seeds given to cattle."

The AOAIXos of Anaxandrides, Athenæus iv. 7, and others, according to Aretæus, is "by some called Аовог;" and in the latter word, we recognise the "loubieh" of Egypt, Dolichos lubia.

The kopiannon of Anaxandrides, Antiphanes, Zeno, Xenocrates, Athenæus ii. 77 and iv. 47, and Macer Floridus 29, according to the received opinion and Sibthorp's account of the Greek usage, is the coriander (Coriandrum sativum).-Pliny states, that "the best coriandrum comes from Egypt;" where, at the present day, the C. sativum is abundantly cultivated.

The sorxos of Antiphanes, Matron, Hegesander, and Athenæus ii. 56 and vi. 57 , according to the received opinion and Sibthorp's account of the Greek usage, is the Sonchus oleraceus. - Forskal, Delile, and others, enumerate the S. oleraceus among the weeds of Egypt.

The kitpion of Antiphanes, Eriphus, Phanias of Eresus, Juba, and Athenæus iii. 26, may be compared with the sweet lemon, or true citron (Citrus Medica).-Theophrastus describes the "melon medikon and persikon" as "having thorns, and bearing at all seasons a fruit which is not eaten;" and Dioscorides adds, that "the fruit is oblong;" particulars, agreeing with the sweet lemon. That the sweet lemon preceded the other species of Citrus in the Mediterranean countries, may also be inferred, from its being almost the only kind cultivated along the Persian Gulf.

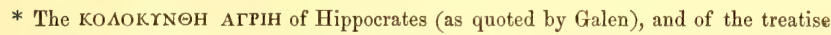
“2 De Mul. Morb. 108,” according to Sibthorp's account of the Greek usage, would seem to be the Bryonia dioica and B. Cretica.-These are indigenous plants of Greece and other parts of Europe; but I have met with no evidence of their being known in Egypt. 
In "B. C. 361" (Clinton ii. pp. 264 and 383), the accession of Nectanebus II., of the Thirtieth Egyptian Dynasty, took place. He was the last of the native Egyptian kings.

The Kastaneia of Mnesitheus, Heracleon Ephesius, and Athenæus ii. 43, according to the received opinion and Sibthorp's account of the Greek usage, is the chestnut (Castanea vulgaris). - A tree originally foreign to Europe (as appears from the testimony of Pliny and others), and expressly enumerated among objects of cultivation by Virgil. The nuts, being mentioned by Athenæus, were of course imported into Egypt; but the living tree appears to be unknown there; though according to Rabbi Schwarz, it grows in Palestine.

In "B. C. 350 " (Clinton ii. p. 383), the Persians under Artaxerxes Ochus, aided by Greek mercenaries, regained possession of Egypt.

The $\Sigma \Phi_{\text {AKon }}$ of Alexis, Aristophon, and Athenæus iv. 69, according to the received opinion, is the garden sage (Salvia officinalis).-This plant was seen by Delile, growing spontaneously at Rosetta.

The оровог of Demosthenes 598, 4, Theophrastus, and others, according to the received opinion and Sibthorp's account of the Greek usage, is the Ervum ervilia.-Alpinus speaks of the cultivation of this plant in Egypt.

The a koniton of Theopompus, Theophrastus, Antigonus Carystius, Euphorion, and Aelius Promotus, according to the received opinion and Sibthorp's account of the Greek usage, is the Aconitum napellus.Belon speaks of an acrid root imported into Egypt, which is called "bisch," and is by him referred to the "napellus."

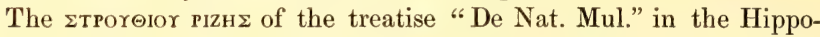
cratic collection, and of Theophrastus, Dioscorides, Lucian, and Galen, according to Sibthorp's account of the Greek usage, would seem to be the Silene behen.-Forskal (Mat. Med.) speaks of the importation into Egypt of "struthium" root from Greece.*

The Batpaxion of the treatises "De Nat. Mul." 29 and " 1 De Mul. Morb.," and the "batrachion triton" of Dioscorides, may be compared with the Ranunculus sceleratus.-This plant is noticed by Gerarde; was seen by Sibthorp at Constantinople and Smyrna; and by Forskal

* The $\odot \Lambda \mathrm{A} \Sigma \Pi$ of the treatise "De Nat. Mul." 29, and of Dioscorides, Pliny, Galen, and Paulus Egineta, is referred by Sibthorp and others to the Thlaspi bursa-pastoris-The "bursam pastoris" of the Liber Saladini, may also be compared. The T. bursa-pastoris was seen by Hasselquist at Jerusalem; but I have met with no evidence of its being known in Egypt. 
and Delile in Egypt; where, moreover, it is used medicinally, as appears from Forskal, p. lv.

The APtemisia of the treatises "De Nat. Mul." 29, "De Superfæt." 19, and "1 De Mul. Morb." 31, and of Dioscorides and Galen, is referred by Sibthorp to the Artemisia arborescens. - This plant is indigenous in the Grecian Archipelago; and was seen by Delile, cultivated in gardens at Cairo.

The eni@rmon of the treatises "De Intern. Affect." 10, and " 2 De Morb. Mulier." 9, and of Dioscorides, Pliny, and Paulus Egineta, is usually referred to the dodder (Cuscuta).-This plant, according to F. Adams, is distinctly described by Serapion. Forskal (Mat. Med.) found "cuscuta" seeds used medicinally by the Egyptians; and the C. Europea and C. monogyna, are enumerated by Delile among the weeds of Egypt.

The medicinal $\triangle$ PAKONTION of the treatises "De Int. Affect." 1 , and "De Steril." 17, of Theophrastus vii. 11, and the "dracunculus having a convoluted root" of Pliny xxiv. 91, may be compared with the Polygonum bistorta; an indigenous plant of Greece and other parts of Europe.-Forskal (Mat. Med.) mentions the medicinal use in Egypt of imported "bistorta" root; and Clot-Bey and Figari speak of the recent introduction there of the living plant.

The apizto Aoxia of the treatises "De Int. Affect." 25, "3 De Morbis" 23, and " 2 De Mul. Morb." 79, and of Theophrastus, Nicander, Dioscorides, Pliny, and Paulus Egineta, is admitted to be one or more of the European species of Aristolochia.-Forskal (Mat. Med.) mentions the importation and medicinal use of "aristolochia" root in Egypt.

The вромог, mentioned as an article of food in the treatise " 2 De Diæta" 12, and noticed by Theophrastus, Polemon, and Athenæus xi. 56 , according to Zalikoglous' account of the Greek usage, is the cultivated oat (Avena sativa); a grain mentioned also by Pliny xviii. 44, as used for food by the Germans.-The A. sativa was seen by Bory de St. Vincent, cultivated and naturalized in Greece; and according to Clot-Bey and Figari, has a native name, and is now cultivated for feeding cattle in Egypt.

The strrxnos of the treatises " 2 De Diæta" 25, and "De Int. Aff." 30, appears to be the "strychnos ypnodes" of Theophrastus and Dioscorides, referred by Sibthorp and others to the Physalis somnifera.-This plant was seen by Forskal and Delile, growing spontaneously at Alexandria and Cairo. 
In "B. C. 338," the accession of Arses, the second Persian king who ruled reconquered Egypt, took place.

In "B. C. 336," the accession of Darius III., the third Persian king who ruled reconquered Egypt, took place.

The inmozeninon of Aristotle (Probl. xx. 7), and Theophrastus vii. 6 , identified by Columella and Pliny with the "atrum olus" of Plautus (Pseudol. iii. 2) and others, is usually referred to the Smyrnium olusatrum.-Apuleius Barbarus speaks of the plant being known in Egypt; but the S. olusatrum has not been found there by modern travellers.

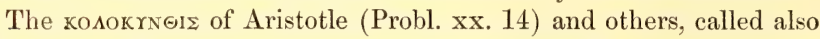
(according to Dioscorides) "kolokyntha alexandrine," is clearly the fruit of the colocynth (Cucumis colocynthis).-This plant does not grow as far north as Greece; but is known to be indigenous in the Desert, from Egypt to the Euphrates and Hindostan.

The aiktamnos of Aristotle viii. 6, Theophrastus, Antigonus Carystius, and Andromachus, according to the received opinion, is the Origanum dictamnus.-Alpinus speaks of the "dictamnus cretensis" being used medicinally in Egypt.

In Egypt, the dried fruit of the Uvaria aromatica is called "amama;" in which word we recognise, the АмऽмоN of Aristotle and Athenæus xi. 11: and the descriptions by Dioscorides, Pliny, and Isidorus, are found to correspond. According to Matthioli, Lobel, and Delile, the fruit of the Uvaria is brought down the Nile from Interior Africa.

The menearpis of Aristotle, Clytus Milesius, Menodotus, Pliny, and Athenæus, according to the received opinion, is the Guinea-fowl (Numida meleagris).-Callixenus states, that "meleagrides" were carried at Alexandria in the festival of Ptolemy Philadelphus: and according to Browne, Guinea-fowl are still imported into Egypt by the Darfour caravans,

In "B. C. 332," Greek rule was established in Egypt by Alexander. In the following year, Alexander proceeded on his Eastern Expedition; which, among other results, contributed essentially to render India better known to the Mediterranean nations.

About this time, Greek inscriptions make their appearance in Egypt. Among the earliest, perhaps, is the papyrus containing a large portion of a lost oration of Hyperides, recently discovered in Egypt by Mr. A. C. Harris. 
According to a statement preserved in Quintus Curtius ix. 25, "The Indians brought dorsa testudinum to Alexander." It seems probable, however, that the traffic in tortoise-shell by the route of the Red Sea, was at this time in existence.-Carvilius Pollio, according to Pliny ix. 13, first taught the art of splitting tortoise-shell.

Nearchus in his account of India (quoted by Strabo xv.) speaks of 乏нPIKA ; usually considered to be silk stuffs, a Chinese manufacture.The importation of silk stuffs into the Mediterranean countries, took place subsequently; but they continued to be so rare and costly, that the Emperor Elagabalus was charged with being the first Roman who wore a dress of silk.

Nearchus (as quoted by Arrian), and Onesicritus (as quoted by Strabo xv.), speak of "the Kathaians tinging the beard of different colours ;" and this was probably accomplished, in part, by the use of henna (Lawsonia).-The introduction of henna into Egypt, appears to have been much later; Lucan iii. 238 , refers the above custom to India; but the "Egyptian kypros" of Dioscorides and Pliny, "the bruised leaves of which redden the hair," corresponds with the henna; and the remarks of Tertullian (De Cult. Fœem. ii. 6), imply a novel practice. Mummies have been discovered, having their nails stained with henna.

Nearchus (as quoted by Strabo xv.) speaks of an Indian "reed that yields honey without the aid of bees;" and in this description, we readily recognise the sugar-cane (Saccharum officinale). - Pliny and Galen speak of manufactured sugar, as "a production of Arabia and India ;" and the living plant does not appear to have been introduced into the Mediterranean countries until a much more recent period.

Aristobulus (as quoted by Arrian) speaks of a species of $\Sigma I \Lambda \Phi I O N$, growing on the Caucasus and used for feeding cattle. The plant corresponds to the Prangos pabularia of the Northern declivity of the Himalaya mountains.

The product attributed to this $\Sigma I \Lambda \Phi I O N$, was doubtless the "opos Medikos" of Strabo xi., Dioscorides, and Pliny, or assafoetida; supposed to be obtained from more than one species of Ferula, growing on the mountains of Persia and Cabul.-The assafoetida of commerce is at least derived from that quarter, for according to Forskal (Mat. Med.), the drug is imported into Egypt from India.

Aristobulus (as quoted by Strabo xv.), and Megasthenes (as quoted by Athenæus iv. 39), speak of the Indians eating oprzA, or rice. The 
Greek word seems to have been derived from the Malay "bras ;" and forms perhaps the earliest instance of the introduction of a Malay term into the Mediterranean languages.-Some centuries later, as appears from Horace, Strabo, Dioscorides, and the Jewish Mishna, the culture of rice was introduced into Babylonia, Syria, and Egypt.

On the death of Alexander, "B. C. 323," Ptolemy obtained the government of Egypt : but the earliest buildings erected by him, bear the names in hieroglyphic characters of Philippus Aridaeus and Alexander IV., the nominal successors to the whole Empire. Ptolemy removed from Heliopolis to Alexandria the two well-known obelisks; and at the mouth of the harbour, he commenced an immense pharos, or light-house (the ruins of which were "one hundred and fifty cubits high" so late as the twelfth century); he also founded the celebrated Alexandrian Library.

Monuments of the reign of Ptolemy and his Greek successors, are numerous in Egypt; but are comparatively uninteresting. Yet the temples are not devoid of architectural taste; and their walls, though chiefly devoted to. Mythology and ostentatious enumerations of conquests, present dates, genealogies, and Astronomical records, that the historian might consult with advantage.

Theophrastus iv. 9, has distinctly described the Pistia stratiotes, as a plant growing in Egypt; and his account of its medicinal use is confirmed by Alpinus.-The Pistia, being an aquatic plant, may have floated down the Nile without human intervention. It was seen in Sennaar by Cailliaud; but nevertheless may not be truly indigenous in Equatorial Africa.

Theophrastus v. 6, mentions a kind of wood, used at Tylos (in the Persian Gulf) for building ships that have been known to keep sound for more than two hundred years : a description corresponding with the teak (Tectona grandis).-Forskal found the keel of the Egyptian vessels made of a wood imported from India, and called "sadj:" on referring to Graham, this is found to be the Bombay name of the teak.

The кар $\triangle$ АM $\Omega$ MON of Theophrastus, of the treatise " 1 De Mul. Morb." 52 (in the Hippocratic Collection), and of Dioscorides and Pliny, is admitted to be cardamoms (the seeds of Elettaria cardamomum).-Edrisi states, that this spice is brought by the way of Aden "from China;" but according to Bontius, the plant grows in Java. I found cardamom seeds in common use throughout the Arab countries; and I met with a quantity, that had been imported by the route of Mecca and the Thebaid. 


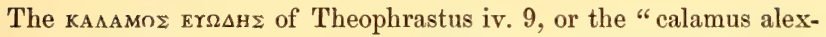
andrinus" of Celsus and Dionysius Periegetes, is referred by Royle to the Andropogon calamus-aromaticus : Dioscorides states, that the plant grows in India.

The sxoinos of Theophrastus ix. 7, Columella, and Damogeron, and the "gramen Arabum" of Propertius xxix. 17, may be compared with the Andropogon schananthus; more generally known under the name of "juncus odoratus." - Alpinus speaks of the importation of juncus odoratus from Arabia into Egypt; and Hasselquist states, that it is "brought from Limbo in Arabia Petræa." According to Bontius, the grass grows wild and is likewise cultivated, in Java.

The когтог imported from India, of Theophrastus ix. 7, Ovid, Celsus, and Lucan, is considered to be the dried root of Aucklandia costus.-Bontius states, that this root is brought to Java from Cambodia.

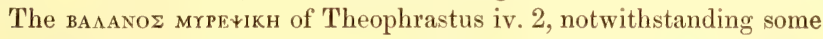
discrepancies in the description, is usually referred to the Moringa oleifera._-Belon and Hasselquist met with the living tree in the Sinai Peninsula; and pods and seeds, were seen by Delile in the drug shops of Cairo.

The "spiny and feather-leaved" sensitive plant growing at Memphis, of Theophrastus iv. 3, and the "aischynomene" of Apollodorus and Pliny xxiv. 17, may be compared with the Mimosa habbas.-This shrub was seen by Delile in the Thebaid; and is indigenous in Abyssinia.

The "Bactrian tree bearing a nut and resembling the terebinth," mentioned by Theophrastus iv. 5, may be compared with the pistachio (Pistacia vera).-In Egypt, the pistachio is called "festok;" in which word, we recognise the "pistaki" of Nicander and Posidonius. Pliny states, that the "pistacia" tree was brought from Syria into Italy a little before the death of Tiberius. Delile speaks of the importation of pistachio-nuts from Syria into Egypt; where, according to Clot-Bey and Figari, the tree is now commonly cultivated.

The An $\triangle$ PaXnH of Theophrastus vii. 1, according to Sibthorp's account of the Greek usage, is possibly the Peplis portula; a European herb, sometimes used for economical purposes at Athens, but which appears to be unknown in Egypt.

Sibthorp, however, refers the AN $\triangle \mathrm{PAXNH}$ of the Ancients to the purslain, Portulaca oleracea.-In Egypt, the purslain is called "rigleh" (a word, according to Schwarz, occurring in the Rabbinical writings), 
and also "bakla" (a word used by Rhazes); but both these terms are sometimes extended to other plants. The purslain is figured by Lobel; but the genus has appeared to me, to be properly Tropical, and not well according with the natural vegetation of the Mediterranean countries.

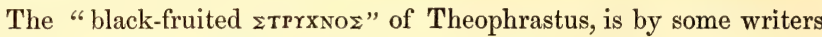
referred to the Solanum nigrum. - This plant is noticed by Camerarius; was seen by Sibthorp in Greece; and by Forskal, Delile, and others, in Egypt; but it may have once been a strictly Tropical weed.

The Arp $\Omega$ sis of Theophrastus, Theocritus xiii. 42, Polybius, Dioscorides, and Athenæus viii. 4, is referred by Sibthorp and others to the Cynodon dactylon.-This grass was probably derived from India; where it is highly esteemed for feeding cattle. It is figured by Dalechamp and Lobel; was seen by Forskal and Delile in Egypt; and is expressly enumerated by Clot-Bey and Figari among the plants employed there for feeding cattle.

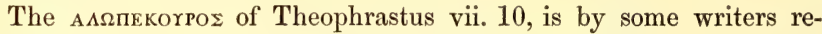
ferred to the Lagurus ovatus; and Sibthorp's account of the Greek usage, corresponds.-This grass was seen by Forskal, growing spontaneously at Alexandria; and Delile considers it indigenous.

The Erzemon of Theophrastus and Dioscorides, or the "eruca" of Ovid, Columella, and Pliny, according to the received opinion and Greek usage, is the rocket (Brassica eruca).-This plant was seen by Alpinus, Forskal, and others, in the gardens of Egypt.

In Egypt, according to Forskal, the Hesperis acris is called "sphæri" in which word, we recognise the Esmepis of Theophrastus (De Causs. vi. 28). - The H. acris, however, is said to be indigenous in Egypt; and the same species has not been found in Greece.

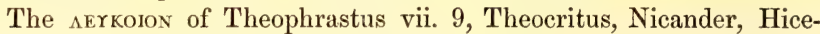
sius, and Philonides, mentioned by Athenæus (v. 25 and xv. 17) as a common garden flower in Egypt, is usually referred to one or more species of Cheiranthus.-According to Callixenus, "leykoion" flowers were used in the festival of Ptolemy Philadelphus: Forskal enumerates a Cheiranthus among the coronary plants of Egypt; and the $C$. incanus was seen by Delile, growing spontaneously at Cairo.

In Egypt, the Trifolium Alexandrinum is called "bersym ;" in which word, we recognise the EPrsimon of Theophrastus. - The T. Alexandrinum is abundantly cultivated in Egypt; and was seen in Greece by Bory de St. Vincent. 
The АФАКн of Theophrastus, Phanias of Eresus, Dioscorides, and Athenæus ix. 7, is by some writers referred to the Lathyrus aphaca. - This plant was seen by Delile, growing spontaneously around Cairo.

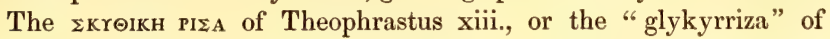
Dioscorides, Pliny, Galen, and Avicenna, according to the received opinion and Greek usage, is the liquorice (Glycyrrhiza).-The G. glabra was seen by Sibthorp in the Grecian Archipelago; and by Forskal and others, in gardens at Cairo.

The тратакаn@a of Theophrastus ix. 1, Celsus, Dioscorides, and Galen, according to the received opinion and Greek usage, is gum tragacanth; procured, according to Hawkins and Sibthorp, partly from the Astragalus aristatus. Confirmation of this account, was also obtained in Greece by Bory de St. Vincent.-Gum tragacanth, under its Arabic name "katira," is mentioned by Rhazes and Ibn Baitar; but according to Forskal (Mat. Med.), is imported into Egypt from Persia.

The тріволог of Theophrastus, according to Forskal's and Sibthorp's account of the Greek usage, would seem to be the Tribulus terrestris.This plant was seen by Forskal and Delile, growing spontaneously in Egypt and Nubia.

Sibthorp, however, found the Onobrychis crista-galli equally called "triboyli" in Cyprus. This plant also was seen by Delile, growing spontaneously at Alexandria.

The петАIкION of Theophrastus and others, referred by Celsus to the "parthenion and herba muralis," may be compared with the Parietaria officinalis. - This plant was seen by Delile and others in Egypt; where it is perhaps indigenous.

In Egypt, the indigenous Marrubium alyssum is called "frasyoun ;" in which word we recognise the חрAгIon of Theophrastus vi. 1, and others, admitted to be one or more of the corresponding species of Marrubium found in Greece.

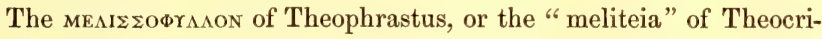
tus, according to the received opinion, is the Melissa officinalis,-Hasselquist met with this plant in Palestine, and also at Damietta.

The xamaisprs of Theophrastus ix. 10, and Dioscorides, according to the received opinion and Sibthorp's account of the Greek usage, is the Teucrium chamcedrys.-The dried plant, as appears from Alpinus, is imported and used medicinally in Egypt.

The manaz hPAKAEION of Theophrastus and others, according to 20 
Dioscorides, is the plant which yields opopanax.-This gum is known to be the product of the Opopanax chironium; and, as appears from Rhazes, Avicenna, Alpinus, and Forskal, is imported and used medicinally in Egypt.

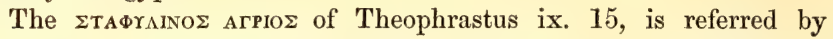
Sprengel to the Ammi visnaga.-This plant was seen by Sibthorp in the Grecian Archipelago; by Hasselquist, on Lebanon; and by Delile and others, growing spontaneously at Alexandria. According to Alpinus, the seeds are used medicinally in Egypt.

The $\triangle$ аяког крнтіког of Theophrastus, Celsus, Petronius Diodotus, Dioscorides, and Pliny, according to the received opinion, is the Athamantha Cretensis.-Alpinus iv. 7, speaks of the medicinal use in Egypt of "daucum" seeds imported from Crete.

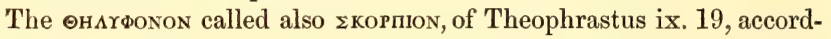
ing to the description of the root, would seem to be the Arnica scorpioides; an indigenous plant of Parnassus and other mountain districts of Europe. Greek usage, however, points to the Doronicum pardalianches, an allied plant, also indigenous on the mountains of Greece.-Forskal (Mat. Med.) speaks of the medicinal use in Egypt of imported "doronicum" root.

The aвpotonon of Theophrastus, Dioscorides, and Pliny, is usually referred to the southern-wood, Artemisia abrotanum.-This plant was seen by Delile in gardens at Alexandria.

The nanaz xeIPRneion of Theophrastus, is referred by Apuleius Barbarus to the elecampane (Inula helenium).- Horace is said to have first taught the art of cooking this plant; and roots prepared for the table, were seen by Belon at Constantinople. The Arab writers speak of the medicinal uses; but the living plant appears to have remained unknown in Egypt.

The акорог of Theophrastus, Celsus, Dioscorides, and Galen, according to the received opinion and Sibthorp's account of the Greek usage, is the Acorus calamus. - The living plant is unknown in Egypt; but the imported root, according to Alpinus, forms one of the ingredients of the Egyptian theriac.

The ефнметоN of Theophrastus and others, referred by Dioscorides to the "kolchikon," according to the received opinion and Sibthorp's account of the Greek usage, is the Colchicum autumnale. - Clot-Bey and Figari, enumerate the C. autumnale among the plants, indigenous or at least long known in Egypt.

In Egypt, the Glaucium violaceum is called "rigl el-ghorab," or 
crow's-foot; which being translated into Greek, becomes the коряNo. пог $\Sigma$ of Theophrastus. - The "kyaneon chelidonion" of Theocritus xiii., may also be compared. The G. violaceum was seen by Sibthorp in Greece and Cyprus ; and by Forskal and Delile, growing spontaneously at Alexandria.

In Egypt, according to Forskal, the Erodium malacoides is called "garna" or "djarna;" in which word we recognise the repanion of Theophrastus, Dioscorides, Athenæus, and Paulus Egineta. The "habhasis" of Leo Africanus v., may also be compared with "kabsjie," the Egyptian name (according to Forskal) of the E. crassifolium. These two plants are considered indigenous by Forskal ; and in addition, the E. reflexum and E.glabellum were seen by Delile, growing spontaneously at Alexandria.

The Haiotronion of Theophrastus, Nicander, Varro, and Dioscorides, is referred by Sibthorp and others to the Heliotropium Europaum.This plant was seen by Forskal and Delile, growing spontaneously at Alexandria. The $H$. supinum was also seen by Sibthorp in the Grecian Archipelago; and by Forskal and Delile, growing spontaneously at Alexandria and Cairo.

In Egypt, the Plantago major is called "lissan el-hamal" or lamb'stongue; which being translated into Greek, becomes the АРNоГА $\Sigma \Sigma$ ON of Theophrastus vii. 9 and 10, Dioscorides, and Macer Floridus.

The AAmA than one species of dock (Rumex).-The Rumex obtusifolius was seen by Sibthorp in Greece; and by Forskal, both at Constantinople, and growing spontaneously at Cairo.

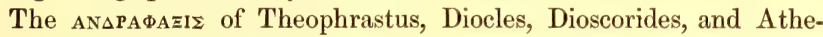
næus ii. 57 , is usually referred to the garden orache (Atriplex hortensis). - This plant was seen by Sibthorp at Constantinople; and by Hasselquist, "in gardens at Damietta." Alpinus enumerates the "atriplex" among the esculent plants of Egypt.

The A AnIA of Theophrastus, Dioscorides, and Paulus Egineta, is usually referred to the Althoea officinalis.-The A. officinalis was seen by Sibthorp in Greece; but according to Clot-Bey and Figari, has been only recently introduced into Egypt. The A. Ludwigii, was seen by Delile in fields near the ancient Bubastis; and the A.cannabina, was seen in Egypt by Forskal.

The ozтакаN@A of Theophrastus, Dioscorides, and Galen, according to the received opinion and Sibthorp's account of the Greek usage, is the barberry (Berberis vulgaris).-This is a Northern plant; but the 
imported fruit is used medicinally in Egypt, as appears from Rhazes and Alpinus.

The ФҮАIKн of Theophrastus iii. 4, according to Sibthorp's account of the Greek usage, would seem to be the Phillyrea latifolia. - This shrub was seen by Clot-Bey and Figari in the gardens of Lower Egypt.

The кікіs, enumerated among Leguminous trees by Theophrastus i. 18, may be compared with the Cercis siliquastrum.-This tree was seen by Sibthorp and others in Greece; by Hasselquist, on Lebanon; and according to Clot-Bey and Figari, is cultivated in gardens at Cairo.

The Kepazos of Theophrastus, Diphilus Siphnius, and Athenæus ii., according to the received opinion and Greek usage, is the cherry (Prunus cerasus). - Pliny states, that this tree "was first brought from Pontus into Italy in the six hundred and eightieth year of Rome;" and alludes also to the fact (confirmed at the present day), that the culture of the cherry does not succeed in Egypt.

A portion of Theophrastus' description of the $\Lambda \Omega$ то $\Sigma$ tree, is referred by Anguillara to the Celtis australis. - The current Greek name of the Celtis suggests also, a possible connexion with the "keratia" of Luke xv. 16, and of Dioscorides. The C. Australis was seen by Belon in Syria; but according to Clot-Bey and Figari, has been only recently introduced into Egypt.

The гнмгАA of Theophrastus (De Causs. plant.) is referred by Scarlatus and others to the birch (Betula alba).-The birch has not been seen in Greece by modern travellers; but according to Clot-Bey and Figari, the tree is planted in the gardens of Egypt.

The ozra of Theophrastus, Strabo, and others, according to the received opinion and Sibthorp's account of the Greek usage, is the beech (Fagus sylvatica).-Forskal mentions the importation of beech timber into Egypt.*

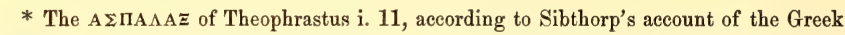
usage, would seem to be the Rhagadiolus edulis. - This plant was seen by Sibthorp in Southern Greece and in Cyprus; but it has not hitherto been found in Egypt.

The PA or PHON, mentioned by Theophrastus as brought from beyond the Bosphorus, and noticed also by Celsus, Scribonius Largus, Dioscorides, and Galen, is usually referred to the garden rhubarb (Rheum Rhaponticum).-This plant is described by Alpinus and Parkinson; but I have met with no evidence of its being known in Egypt.

The трагоп $\Omega \Omega N$ of Theophrastus and Dioscorides, according to the received opinion, is the salsify (Tragopogon porrifolius).-This plant was seen by Sestini at Constantinople; and by Bory de St. Vincent, in Greece; but it appears to have remained unknown in Egypt. 
The anikakaboz of Diocles, Evenor, Timaristus, Celsus, and Dioscorides, mentioned by Pliny as occurring in Egypt, is referred by Sibthorp and others to the Physalis alkekengi.-This plant is noticed by Avicenna, Mesue (De simplic.), and Matthioli ; but according to ClotBey and Figari, has been only recently introduced into Egypt.

Menecrates Elaita and the Pseudo-Xanthus (as quoted by Strabo xii.) speak of "the Mysians being named after a tree :" the reverse of such derivations is not uncommon; but leaving fact out of view, the tree alluded to by these writers was perhaps the apricot (Prunus Armeniaca), called "mish" in Egypt.-The apricot is distinctly mentioned by Columella, Pliny, and Galen; and at the present day, is a favourite object of cultivation in the Arab countries, both within and without the Tropies.

The пергіка of Diphilus Siphnius, Philotimus, and Athenæus iii. 24, appears to be the peach (Amygdalus Persica).-This fruit is not mentioned by Virgil; but a century later, we find it figured in the Herculaneum paintings and well known in Italy. Pliny alludes to its presence in Egypt; where, at the present day, it is commonly cultivated.

In "B. C. 285," Ptolemy abdicated in favour of his son: and "in the ensuing winter, or at the commencement of B. C. 284" (Champollion-Figeac), a noted festival was held at Alexandria; coincident apparently with the commencement of the Dionysian Era (see the detailed description by Callixenus). Ptolemy II., or Ptolemy Philadelphus, was at this time the acknowledged king. His name in hieroglyphic characters has been found on various monuments. He built the temple at Philæ; completed the pharos or light-house at Alexandria : and his memory has been always cherished, from the patronage he extended to Literature, and the large additions he made to the Alexandrian Library.

The комаро乏 of Theocritus v. 129, according to Sibthorp's account of the Greek usage, would seem to be the European strawberry (Fragaria vesca).-The strawberry is also mentioned by Virgil, Ovid, and Nicolaus Myrepsus : its introduction into Egypt, will be noticed hereafter.

The aKan@os of Theocritus i. 55, Virgil, Vitruvius, and Ovid, seems to correspond with the Acanthus mollis.-This species, distinguished by Pliny xxii. 34, was seen by Sibthorp only in Sicily; and is enumerated by Clot-Bey and Figari among the plants recently introduced 
into Egypt. On the other hand, the A. spinosus was seen by Sibthorp and Bory de St. Vincent, growing abundantly in the Grecian Archipelago; but it appears to be unknown in Egypt.

The хамапітуг of Apollodorus, Nicander, Celsus, Dioscorides, and Athenæus xv., is usually referred to one or more species of Ajuga.The "chamaipitys" entered into the composition of the theriac of Andromachus: and the Ajuga iva is enumerated by Alpinus among the ingredients of the Egyptian theriac; and was seen by Delile, growing spontaneously at Alexandria.

The BornaErron of the treatise "De mul. morb." (in the Hippocratic collection), and of Glaucon, Epænetus, Nicander, Pliny, and the Scholiast of Pliny, is referred by Dodonæus to one or more species of Bupleurum. - The B. rotundifolium and B. semicompositum were seen by Sibthorp in Greece; and by Delile, growing spontaneously at Alexandria.

The zaranEnor of the treatise " 1 De mul. morb." 108, and of Celsus, Dioscorides, Pliny, Marcellus, and Galen, is admitted to be sagapen (a gum imported from Persia, and supposed to be the product of Ferula Persica).-According to Greenhill and F. Adams, gum sagapen is also mentioned by Rhazes, Avicenna, Ibn Baitar, and other Arab writers.

The aรApon of the treatise " 1 De mul. morb." 45, and of Dioscorides, Pliny, and Paulus AEgineta, according to the received opinion and Sibthorp's account of the Greek usage, is the Asarum Europoum.Forskal (Mat. Med.) notices the medicinal use in Egypt, and the importation of " asarum" root from Greece.*

In "B. C. 247," the accession of Ptolemy III., or Ptolemy Euergetes, took place. His name occurs in hieroglyphic characters on temples, at Dakkeh, Philæ, Esneh, and Thebes : and a Greek inscription relating to his reign, was discovered by Cosmas Indicopleustes at Adule on the Abyssinian coast. Ptolemy III. conducted a military expedition as far as Bactria; and brought back to Egypt the sacred objects that had been carried away by the Persians. He was suc-

* The moArKa PION of the treatise " 1 De mul. morb." 90 , according to Sibthorp's account of the Greek usage, would seem to be, either the Opopanax Chironium (already noticed) or one or more species of Thapsia.-The species of Thapsia are indigenous plants of Greece and other parts of Europe, and have been sometimes used medicinally; but $I$ have met with no evidence of their being known in Egypt. 
cessful also in his naval enterprises; but amid warlike operations, he continued to bestow great attention on the encouragement of Literature and on the increase of the Alexandrian Library.

The commencement of Roman Literature is referred, by general consent, to the first dramatic exhibition of Livius Andronicus, in "B. C. 240." This writer was however by birth a Greek : but twenty-two years later, both he and the four native Roman writers, Nævius, Plautus, Ennius, and Cato, were all living.

In "B. C. 222," the accession of Ptolemy IV., or Ptolemy Philopator, took place. He built the temple at Akhmin; continued that at Dakkeh in Nubia; and founded the great temple at Edfu: his name in hieroglyphic characters occurs also on buildings at Esneh and Karnac; on some restorations at Luxor; and on the small temple of Athyr, situated upon the western declivity of the river valley at Thebes.

The PETALion of Plautus (Curcul.), is referred by Stapel to the "malabrathrum" of Horace, Ovid, Andromachus, and Claudius Ptolemæus; an article of importation from India.-Identified by Ainslie and Royle, and described by them as consisting of the dried leaves of Laurus cassia, mixed sometimes with those of $\mathrm{L}$. cinnamomum.*

In "B. C. 205," the accession of Ptolemy V., or Ptolemy Epiphanes, took place. During his reign, a large amount of building was accomplished; especially at Philæ, Edfu, Esneh, and Thebes. He founded the temple at Ombos: and his name occurs in the Greek inscription dedicating the small temple at Philæ to Aesculapius.

The Rosetta Stone is dated in the " ninth year of the reign of Ptolemy Epiphanes." It is inscribed with a decree in hieroglyphic and also in demotic writing, with a Greek translation; and has proved the means of recovering the art of reading hieroglyphic characters.

In "B. C. 181," the accession of Ptolemy VI., or Ptolemy Philometor, took place. During his reign, temples were erected or continued at Paremboleh in Nubia, at Philæ, Ombos, Edfu, Koos, and

* The verbena of Plautus, Terentius, Livius, Propertius, and Pliny, has been identified with the "peristereona" of Cratevas and Dioscorides; a word having a like signification with the "phassochorton" of the modern Greeks, Prasium majus. This plant, moreover, has been found growing at Rome, as appears from Persoon. - I have met with no evidence, that it is known in Egypt. 
Antæopolis : his name occurs on these temples both in hieroglyphic and in Greek inscriptions; and according to Champollion-Figeac, he dedicated some Egyptian temples to the gods of Greece.

Some applications of steam as a mechanical agent, are described in the writings of Heron of Alexandria.

The gentiana, discovered (according to Pliny xxv. 34) by Gentius the king of the Illyrians, is admitted to be the officinal gentian (Gentiana lutea).-This plant has not been seen within the proper limits of Greece; but it grows on the neighbouring Alps. The imported root, according to Alpinus, is one of the ingredients of the Egyptian theriac.

The חrPE@PON of Nicander (Ther. 938), Celsus, Dioscorides, and Serenus Sammonicus, is referred by Tragus and J. E. Smith to the Anthemis pyrethrum.-Macer Floridus enumerates the "pyrethrum" among exotics; and the dried roots of the A. pyrethrum, are known to be imported from Spain into the rest of Europe, and from Barbary into Egypt. Alpinus and Forskal (Mat. Med.) speak of the medicinal use of "pyrethrum" root in Egypt.

The ozAAII of Nicander (Ther. 840) and Dioscorides, according to the received opinion and Sibthorp's account of the Greek usage, is one or more species of sorrel (Rumex).-The $R$. acetosella was seen by Hasselquist at Damietta; but the cultivated sorrel, $R$. acetosa, according to Clot-Bey and Figari, has been only recently introduced into Egypt.

The күмоглаггог of Nicander (Geor.), Celsus v. 27, Dioscorides, and Athenæus, is referred by Sibthorp and others to the Cynoglossum officinale.-This plant was seen by Hasselquist in Palestine; but according to Clot-Bey and Figari, has been only recently introduced into Egypt.

The полүгоnon of Nicander (Ther. 901) and Dioscorides, is usually referred to the Polygonum aviculare.-This plant is noticed by Lobel and by Tabernæmontanus : and was seen by Hasselquist in Palestine ; and by Delile, growing spontaneously at Alexandria.

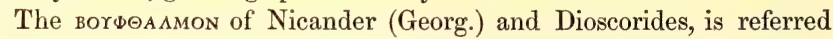
by Sibthorp to the Chrysanthemum segetum. - This plant, though common in Greece, has not been seen in Egypt; for Forskal's notice, is referred by Delile to the closely allied Chrysanthemum coronarium; observed growing in the assigned locality, near Alexandria.*

* The $\Omega X P O N$ ION of Nicander (quoted by Athenæus xv.), and the "leykoion melinon" of Dioscorides and Oribasius, are referred by Stapel, Sibthorp, and others, to the gilly-flower, Cheiranthus cheiri.-This plant appears to be common in Greece; but I have met with no evidence, that it is known in Egypt. 
Towards the close of the reign of Ptolemy Philometor, the Jews under Onias, sought and obtained a grant of the temple of Bubastis for a place of religious worship.

In "B. C. 146," the accession of Ptolemy VII., or Ptolemy Physcon, took place. During his reign, additions were made to the temples at Dakkeh in Nubia, at Philæ, Ombos, and Edfu; he built the small temple of Thoth at Medinet-Habu; and his name in hieroglyphic characters has also been found on restorations in the Asasif, and on the temple of Athyr at Thebes. A petition addressed to him in Greek by the priests at Philæ, has afforded the means of verifying hieroglyphic interpretations derived from the Rosetta Stone. One of his provincial governors was a Roman.

The aursion of Antonius and others, according to the description by Dioscorides, would seem to be a species of Biscutella.-The B. apula was seen in Greece by Sibthorp, and was received from Egypt by Jussieu. The B. depressa was seen by Delile, growing spontaneously at Alexandria.

In Egypt, the taro (Colocasia esculenta) is called "kolgas;" in which word we recognise the колокагіa of Glaucias, Virgil, Columella, Claudius Iolaus, and Pliny xxi. 102.

Certain Indian weeds appear to have accompanied the culture of taro and rice into Egypt; and being inconspicuous objects, may have been overlooked by the ancient writers: as, the Sphenoclea; the Sphoeranthus; a species of Grangea; the Eclipta erecta; the Ethulia conyroides; the Jussicea diffusa; the Ottelia alismoides; the Elatine verticillata; the Ammania auriculata and A. Agyptiaca; the Cyperus alopecurus and C.dives; and the Panicum colonum; all seen by Delile in the rice-grounds of Egypt.

In "B. C. 117," the accession of Ptolemy VIII., or Ptolemy Lathyrus, took place. His name in hieroglyphic characters has been found on a propylon at Koos; on the temples at Ombos and Edfu; and on that of Athyr at Thebes: he made some extensive restorations at MedinetHabu, with materials derived from Pharaonic ruins.

The CHanopadas of Lucilius, Pliny, and Macrobius, may be compared with the species of Chenopodium. - The C. rubrum was seen by Sibthorp at Constantinople; and by Forskal, growing spontaneously at Cairo. The C. album was seen by Sibthorp in Greece; and by Forskal and Delile, growing spontaneously at Cairo. The C. murale was seen by Sibthorp at Constantinople; and by Delile, growing spontaneously at Cairo. 
A deed for the sale of a piece of land, executed in B. C. 105, has been discovered; and is translated by Champollion-Figeac, p. 439. It is accompanied with evidence, that the system of Public Registry was in force.

When Ptolemy Lathyrus was recalled to Egypt, the city of Thebes refused to acknowledge his authority, and held out for nearly three years ; but was finally captured in "B. C. 87 ;" and on this occasion, the monuments are said to have sustained much injury.

The name of Ptolemy IX., or Ptolemy Alexander I., has been found in hieroglyphic eharacters on the monuments; but his reign is included in that of his brother, Ptolemy Lathyrus, already mentioned. The accession of Ptolemy X., or Ptolemy Alexander II., took place "in B. C. 81 ;" but his reign appears to have lasted only a few months; and his name has not been found on the monuments, nor even upon coins.

In “B. C. 80," the accession of Ptolemy XI., or Ptolemy Auletes, took place. His name (according to Champollion-Figeac) has not been found in hieroglyphic characters; but occurs on coins, and in Greek inscriptions in red ink at Philæ.

Iambulus, who appears to have visited some of the East African islands, met with persons "who wrote in vertical columns" (see Diodorus Siculus ii. 55). This, it will be observed, is the Chinese method of writing: though something of the same sort, is found on the eyepaint bottles manufactured on the Persian Gulf. - The eye-paint bottles discovered in Egyptian tombs, together with real Chinese manufactures, were evidently deposited at a comparatively recent period.

The $\Sigma$ Kor $\triangle 10$ of Mithridates, Lenaeus, Dioscorides, Pliny, and Galen, according to the received opinion and Sibthorp's account of the Greek usage, is the Teucrium scordium.-Alpinus met with the pulverised leaves of T. scordium among the ingredients of the Egyptian theriac; but the living plant, according to Clot-Bey and Figari, has been only recently introduced into Egypt.

Diodorus Siculus (i. 46 and 47) visited Thebes in the "one hundred and eightieth Olympiad" (B. C. 60); at which time, the great syenite colossus of Ramses II. was still entire.

The nasturtium of Varro and Columella, is usually referred to the water-cress (Nasturtium officinale).-This plant was seen by Sibthorp in Greece; and by Hasselquist in Palestine; but according to Clot-Bey and Figari, has been only recently introduced into Egypt. 
According to Cæsar, the people of Britain painted themselves with GLASTUM; usually considered to be woad (Isatis tinctoria).-Dioscorides and Paulus Agineta speak of the "isatis" used by dyers: the I. tinctoria was seen in Greece by Bory de St. Vincent and Gittard; but it appears to have remained unknown in Egypt.

In "B. C. 51," the accession of Cleopatra took place. Her name occurs in hieroglyphic characters on various Egyptian monuments: she built the small temple at Erment, or Hermonthis; and founded the temple at Dendera.

The coins issued by Anthony and Cleopatra, bear perhaps the earliest Latin inscriptions hitherto discovered in Egypt.

With the death of Cleopatra, "B. C. 30," the independence of Egypt ceased; and Augustus became the sole ruler of the Roman World. From this time, also, gold disappears from the Egyptian coinage. Augustus first carried obelisks away from Egypt; but he continued the temple at Dendera; and his name in hieroglyphic characters has been found on buildings at Talmis, Kalabsheh, Debot, Dendur, Philæ, and on the temple of Isis at Thebes. His first prefect, Cornelius Gallus, is accused of permitting statues of himself to be erected, and of having pillaged the city of Thebes.

The Lutum of Virgil, Vitruvius, and Pliny, is referred by Fee to the Reseda luteola. - This plant was seen by Forskal and Delile in cultivated ground at Cairo; and is enumerated by Clot-Bey and Figari among the plants used for dyeing in Egypt.

The rododaphne of the Culex, and of Dioscorides, Pliny, and Apuleius, is clearly the Nerium oleander.-The oleander is enumerated by Delile and others among the garden plants of Egypt; and is said to abound in Syria in a seemingly wild state; but it does not harmonize with the vegetation of the Mediterranean countries: I met with it truly indigenous on the banks of the Godaveri in the Dekkan.

The herba vetronica of Antonius Musa, Celsus v. 27, and Pliny, according to the received opinion and Sibthorp's account of the Greek usage, is the Betonica alopecuros.-The dried plant, as appears from Alpinus, is imported and used medicinally in Egypt.

Strabo, during his visit to Egypt, heard that sounds were uttered by one of the colossi on the plain at Thebes.-But this deception of the Vocal Memnon, did not become an object of pilgrimage until some eighty years later. At the present day, the base of the colossus in question, is found to be covered with Greek and Roman inscriptions; the certificates of visitors who had "heard Memnon." 
According to Beckmann, the NIGRUM INDICUM of Vitruvius, Pliny, and Paulus Egineta, is India ink; and indeed, Pliny xxxv. 25, distinctly speaks of a kind of ink imported from India. Notwithstanding the name, India ink is properly a Chinese manufacture.

In Egypt, according to Forskal, the Gomphroena globosa is called "ambar;" a word not unlike the amaranthus of Tibullus iii. 4, and Philostratus; and indeed, the description of the "amaranto" by Pliny xxi. 23, seems to correspond. The plant, as appears from Rumphius and Rheede, was derived from India.

The EY₫OPBION discovered by Juba on Mount Atlas (mentioned by Pliny xxv. 38), according to the received opinion and the description by Leo Africanus, is a species of cacti-form Euphorbia which seems to be peculiar to Western Barbary. Corresponding species, however, are found in Southern Africa and in Hindostan. The drug obtained from this plant, is noticed by Dioscorides, Galen, Aetius, Paulus Egineta, and the Arab medical writers.

The "succinum indicum containing lizards" of Archelaus and Pliny xxxvii. 11, is clearly gum copal; derived of course originally from Equatorial Africa.

In "A. D. 14," the accession of Tiberius, the second Roman Emperor, took place. His name in hieroglyphic characters has been found at Philæ, Esneh, Karnak, and Dendera : he continued the temple at Debot in Nubia.

The zingiber of Celsus, Dioscorides, and Pliny, is clearly ginger (Amomum zingiber); and it will be observed, that the Latin name indicates the commercial source.-Cailliaud found "ginger rare at Quamamil (on the Bahr el Abiad), brought principally from Abyssinia, and called by the negroes 'zymbane:" at Zanzibar, however, the roots are imported from the Comoro Islands; and they may have first reached Egypt from this ultimate source, and by the inland route.

The AloE of Celsus, Dioscorides, Pliny, and Plutarch, is admitted to be the drug aloes; mentioned as "imported from India," though of course, derived originally from Socotra and the Somali country.Living plants of the A. vulgaris, were seen by Sibthorp in Cyprus; and by Forskal and Delile in gardens at Cairo.

The Lycium of Celsus iv. 4 and 3, Dioscorides, Pliny, Galen, Oribasius, and Paulus Agineta, may be compared with "myilkynia," the modern Greek name of Berberis Cretica. Alpinus (Exot. i. 2) inclines 
to refer the Arxion to this plant; but we are uninformed in regard to any medicinal juice procured from the root.

The ARGEMONIA of Celsus v. 27, is by some writers referred to the Agrimonia.-This plant was seen in Greece by Sibthorp; and Alpinus and Forskal (Mat. Med.), speak of the importation and medicinal use of "agrimonia" in Egypt.

The Petroselinum of Celsus, Dioscorides, Pliny, Galen, and Paulus Egineta, is referred by F. Adams to the stone parsley (Bubon Macedonicum).- This plant was seen by Belon in the market at Constantinople; but appears to have remained unknown in Egypt.

The PSYllion of Celsus v. 2, Dioscorides, Pliny, and Galen, is usually referred to the Plantago psyllium; and Sibthorp's account of the Greek usage corresponds.-The imported seeds were seen by Delile in the drug shops at Cairo.

In "A. D. 37," the accession of Caius Caligula, the third Roman Emperor, took place.-His name in hieroglyphic characters has been found on temples at Talmis in Nubia, at Philæ, and at Dendera : and at the last-mentioned place, a Greek inscription contains the name of his prefect, Publius Avilius Flaccus. One of the obelisks at Rome, was brought from Egypt by Caius Caligula (see Pliny xvi. 76, 2).

In "A. D. 41," the accession of Claudius, the fourth Roman Emperor, took place. His name in hieroglyphic characters has been found on temples at Philæ, Edfu, Esneh, and Dendera. A Greek inscription, dated in the ninth year of his reign, was discovered by Hoskins in the Great Oasis.

- With the reign of Claudius commences that celebrated Series of Egyptian coins, which has rendered so much service to the historian and chronologer: each coin specifying the year of the reigning emperor ; a variety of coins, being often issued within a single year; while nearly every year is accounted for.

The zIzYPHus of Columella and Pliny, according to the received opinion, and the account of the usage in Greece by Sibthorp, and in Lebanon by Rauwolf, is the jujube (Zizyphus vulgaris). - This tree, according to Forskal, Clot-Bey, and others, is often planted around the Egyptian villages.

In "A. D. 54," the accession of Nero, the fifth Roman Emperor, took place. His name occurs in hieroglyphic characters on the temple at Dendera : and an inscription relating to his prefect Balbillus, has been found near the Great Sphinx at Gizeh. 
The Kannoc of Dioseorides, Pliny, Galen, and Paulus Egineta, according to the received opinion and Sibthorp's account of the Greek usage, is one or more species of Fumaria.-The Fumaria officinalis, has a native name, and is enumerated by Forskal and Delile among the weeds of Egypt. The $F$. capreolata and $F$. parviflora, were also seen by Delile, growing spontaneously at Alexandria and Cairo.

The A ferred to the Malva.alcea.-This plant was seen in Greece by Gittard and Bory de St. Vincent; and according to Clot-Bey and Figari, has been long known in Egypt.

The eAzinh кiccammenoc of Dioscorides and Paulus Agineta, is referred by Sibthorp to the Antirrhinum Egyptiacum. - This plant was seen by Sibthorp in cultivated ground in the Grecian Archipelago; and by Forskal and Delile, in the Egyptian Desert. The A. elatine was also seen by Sibthorp in the cultivated fields of Greece and Cyprus; and by Delile, growing spontaneously at Alexandria.

The пепАос of Dioscorides, is usually referred to the Euphorbia peplus. - This plant was seen by Sibthorp in Greece; and is enumerated by Forskal, Delile, and others, among the weeds of Egypt.

The тіөтмалос натоскопюо of Dioscorides, Rufus Ephesius, and Paulus Egineta, is referred by Sibthorp to the Euphorbia helioscopia.This plant was seen by Delile, growing spontaneously around Cairo, and also in Upper Egypt.

The AEIZSN MIKPON of Dioscorides, according to the received opinion, is one or more species of Sedum.-The Sedum confertum was seen by Forskal and Delile in gardens at Cairo.

In Egypt, the Lemna polyrhiza is called "ads el-ma," or water lentil ; which being translated into Greek, becomes the "aquatic ФAкос" of Dioscorides, Pliny, and Paulus Egineta. The L. polyrhiza and $L$. gibba, were seen by Delile, growing spontaneously at Rosetta; but they may have been originally Northern plants.

The A IICMA of Diascorides and Pliny, is referred by Sibthorp and others to the Alisma plantago.-This is a semi-aquatic Northern plant; seen however by Delile, growing spontaneously at Rosetta.

The pasaric of Dioscorides, Pliny, Galen, and Paulus Egineta, is referred by Sibthorp and others to the Phalaris Canariensis. - The "anemochorton" of Nicolaus Myrepsus, according to Forskal's account of the Greek usage, is the same plant. This grass was seen by Hasselquist, Forskal, and Delile, growing spontaneously in Lower Egypt. 
The कoInIz herb of Dioscorides iv. 43, and Paulus Egineta, identified by Pliny (xxii. 65) with the "hordeum murinum," may be compared with our modern Hordeum murinum.-This grass was seen by Sibthorp in the Grecian Archipelago; by Hasselquist, at Damietta; and by Forskal, growing spontaneously at Alexandria.

The хамaimhaon of Dioscorides and Pliny, according to Sibthorp's account of the Greek usage, would seem to be the Matricaria chamomilla. - This plant was seen by Hasselquist in Palestine; and by Delile, growing spontaneously at Rosetta.

The сиияво of Dioscorides iv. 156, and Pliny, is referred by Lobel to the Carduus marianus.-This plant appears to be the "herbe sancte marie" of Nicolaus Præpositus (125), Franciscus Pedemontium, and Joannes de Sancto Amando. It was seen by Belon at Constantinople; by Sibthorp, in Greece and Cyprus; and by Forskal and Delile, growing spontaneously at Cairo.

The zaneion of Dioscorides, Galen, and Paulus Agineta, is usually referred to the Xanthium strumarium.-This plant is figured by Lobel : was seen in Greece by Sibthorp; and by Delile, in Egypt; where I frequently met with it, growing along the river-bank.

The AMBPocia, or вотPYC APTEMicia, of Dioscorides and Pliny, is referred by Lobel and Dodonæus to the Ambrosia maritima.-This plant was seen by Forskal and Delile, growing spontaneously at Cairo and Alexandria.

The AEnision of Dioscorides, Pliny, Galen, and Paulus Agineta, according to the received opinion and Sibthorp's account of the Greek usage, is the Lepidium latifolium. - This plant was seen by Delile, growing spontaneously at Cairo ; and according to Clot-Bey and Figari, has been long known in Egypt.

The batpaxion and arpioceninon of Dioscorides, according to Sibthorp's account of the Greek usage, would seem to be the Ranunculus Asiaticus. - This plant was seen by Sibthorp, growing wild in Asia Minor and Cyprus; and according to Clot-Bey and Figari, is cultivated in the gardens of Egypt.

The KYMINON ATPION ETEPON of Dioscorides iii. 62, is referred by Valerius Cordus to the Nigella arvensis. - This plant was seen by Forskal and Sibthorp in Greece and Cyprus; and by Delile, growing spontaneously at Alexandria. The $N$. damascena, also seen by Sibthorp in Greece, is enumerated by Clot-Bey and Figari among the plants long known in Egypt. 
The enaia ai@ionikh of Dioscorides i. 136, is referred by Sprengel to the Elcagnus Orientalis. - This shrub was seen by Delile and others in gardens at Cairo.

The DIALYPEA of Dioscorides and Paulus Agineta, according to Hawkins' and Sibthorp's account of the Greek usage, would seem to be the Rhamnus infectorius.-The berries of this shrub form an article of commerce; and under the name of "Turkey berries," are exported from the Eastern portion of the Mediterranean.

In Egypt, the borage (Borago officinalis) is called "lesan el-tour," or ox-tongue; which being translated into Greek, becomes the

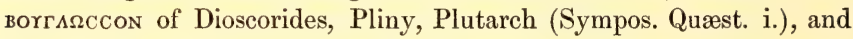
Galen. The B. officinalis, seen by Forskal and others in gardens in Egypt, is used there medicinally, as appears from Alpinus: an indigenous species, B. Africana, is called "horreyg" or "horræjg;" in which word we recognise the "corrago" of Apuleius Barbarus.

The maron of Dioscorides, is referred by Matthioli and others to the Teucrium marum.-This plant in its wild state, was long supposed to be peculiar to Spain, where it was discovered by Clusius : but it has recently been found on the mountains of Greece, by Bory de St. Vincent and Gittard. It is enumerated by Clot-Bey and Figari, among the plants introduced from the French gardens into Egypt.

The Kapon of Dioscorides, Pliny, Galèn, and Oribasius, according to the received opinion, is the caraway (Carum carvi).-Pliny states, that the Greek name is derived from Caria, in Asia Minor. However this may be, the plant is called " karawih" in Egypt; and Delile found the seeds sold in the shops at Cairo.

The Arrrctikon of Dioscorides, Pliny, and Apicius, is usually referred to the lovage (Levisticum).-This plant was seen by Pococke in Palestine; but appears to have remained unknown in Egypt.

The AKAKanIC of Dioscorides and Paulus Egineta, so far as regards the origin of the word, may be compared with "kolkol," the current name in Yemen of one or more species of Cassia : the medicinal use of the AKAKAAIC, was found by Royle to correspond with that of the Cassia absus.-This plant was seen by Alpinus, Hasselquist, and Delile, in the gardens of Egypt; and according to Royle, is indigenous in Hindostan.

The AMM 2 niakon of Dioscorides, Galen, and Paulus Agineta, according to the received opinion, is gum ammoniac; said to be the product of the Dorema ammoniacum.-The drug is used medicinally in Egypt, as appears from Rhazes, Avicenna, and Alpinus. 
The Maker of Dioscorides, Pliny, and Paulus Egineta, according to Alpinus, is a bark brought from Barbary to Egypt; where it is called "selica seuda," and is confounded with the spice, cassia. I can find no account of a Laurus growing on Mount Atlas; but several species occur in Madeira and the Canary Islands.

The саркоколал of Dioscorides, Pliny, Galen, and Paulus Egineta, is admitted to be sarcocol.-This gum, according to the Greek Version, is mentioned by Rhazes: its medicinal uses are likewise noticed by other Arab writers.

The Arkion Inaikon of Dioscorides, Pliny, Galen, Aretæus, and Paulus Egineta, is referred by Royle to the concrete juice of Berberis lycium; a plant growing on the mountains of Northern India.

The araı Isidorus, is usually referred to the lign-aloes (the wood of Aloexylon agallochin).-This tree, as appears from Bontius and Loureiro, grows in Sumatra and Cochin China: Alpinus speaks of the medicinal use of the wood in Egypt.*

In "A. D. 64" (Clinton), the First persecution of the Christians took place: mentioned by Tacitus xv. 44, Suetonius (Ner. c. 16), and Tertullian (Apologet.)

About "A. D. 65," according to the traditions of the church, Christianity was introduced into Egypt by the Evangelist Mark: who left Annianus, or Annaniah, to watch over the new converts. - The names of the successors of Annianus, are given in an uninterrupted series by Eusebius.

In "A. D. 68," the accession of Galba, the sixth Roman Emperor, took place. His name occurs on coins issued in Egypt; and a Greek inscription, dated in his brief reign, has been found at the Great Oasis.

In "A. D. 69," the accession of Otho, the seventh Roman Emperor, took place. His name occurs on coins issued in Egypt, and has been found in hieroglyphic characters on a propylon at Thebes. He was succeeded by Vitellius; whose name has also been found on coins issued in Egypt.

* The EムAфовоскоN of Dioscorides, Pliny, Aetius, and Paulus Egineta, is referred by Sibthorp to the parsnip (Pastinaca sativa).-The parsnip is figured by Matthioli, and by Lobel ; but it appears to have remained unknown in Eggpt.

The $\triangle \mathrm{I} \Psi \mathrm{AKOC}$ of Dioscorides and Pliny, is usually referred to one or more species of Dipsacus : and the "carduus nondum fullonibus aptus" of Serenus Sammonicus, implies a knowledge of the cultivated teazle (D. fullonum).-This plant appears to be unknown in Egypt. 
In the same year, the accession of Vespasian, the ninth Roman Emperor, took place. His name has been found in hieroglyphic characters on the temple at Esneh; on a building at Thebes; and on an obelisk at Rome.

The ANATAMAIC ENYAPOC of the synonyms added to the work of Dioscorides ii. 153, is referred by Fuchsius and others to the Veronica anagallis.-This plant was seen by Sibthorp in the Grecian Archipelago; by Delile, growing spontaneously at Rosetta ; and by Forskal, in the mountain region of Yemen. The closely allied $V$. beccabunga was seen by Sibthorp in Greece; and is enumerated by Clot-Bey and Figari among the plants long known in Egypt.

Pliny xii. 15, had heard of an article used in India, resembling pepper, and called GARYOPHYLLON; and under this name, Paulus Ægineta distinctly describes cloves (Caryophyllus aromaticus); a production of the Molucca Islands.-Rhazes, Avicenna, and Symeon Sethus, likewise speak of cloves: I saw in Egypt a quantity that had been imported by the route of Mecca and the Thebaid.

The cranus, supposed by Pliny (xxi. 24) to have recently come into notice, according to Scarlatus' account of the Greek usage, is the Centaurea cyanus. - This plant was seen by Sibthorp in Greece; but according to Clot-Bey and Figari, has been only recently introduced into Egypt.

The herba IMPIA of Pliny xxiv. 113, is referred by Tournefort and others to the Gnaphalium Germanicum.-This weed was seen by Sibthorp in the Grecian Archipelago; and by Delile, growing around Alexandria and Cairo.

The AMOMON herb of Pliny xxvi. 19, seems to correspond with the "ammonos, astrion, and sagginariam" of Actuarius, referred by Stapel to the Plantago coronopus. - This plant was seen by Sibthorp in the Grecian Archipelago; and by Forskal and Delile, growing spontaneously at Cairo and Alexandria. The $P$. lagopus, was also seen by Sibthorp in the Grecian Archipelago; and by Delile, growing spontaneously at Alexandria.

The CHORtinon of Pliny xv. 7, may be compared with the "kurth" of Abu Hanifa, Ibn Redwhan, and Ibn Baitar; which, according to Egyptian usage, would seem to be the Trifolium resupinatum.-This plant was seen by Sibthorp in Greece; and by Forskal and Delile, at Rosetta, Damietta, and Cairo.

Pliny xxv. 6, distinctly describes the scurvy, as a disease of the region beyond the mouths of the Rhine; and mentions the HERBA BRI- 
TANNICA, shown to the Romans as a remedy. The Cochlearia officinalis may be compared.-This is a Northern plant, not found in Greece; and according to Clot-Bey and Figari, only recently introduced into Egypt.

The ACER Gallicum of Pliny xvi. 26, seems to correspond with the Acer pseudo-platanus. - This is a Northern tree, seen by Forskal at Constantinople; but not found in Greece by Sibthorp. According to Clot-Bey and Figari, both this and the A.platanoides (another North European tree) have been recently introduced into Egypt, where they are now planted in gardens.*

In " A. D. 79," the accession of Titus, the tenth Roman Emperor, took place.

The Eruption of Vesuvius on the "24th of August" in the same year, overwhelming the cities of Herculaneum and Pompeii, forms a striking chronological landmark. The brevity of the reign of Titus, leaves but slight room for error in the date; the event being attended by the death of Pliny, limits his Encyclopedic summary of the state of human knowledge; while coeval testimony, amply illustrating the whole condition of society, is found in the vast variety of objects disinterred. $\dagger$

\section{THE EARLY CHRISTIAN, OR THE COPTIC PERIOD.}

In this extraordinary manner, two Heathen cities, all but their inhabitants, have been preserved; and from about the latest possible moment: Josephus was even then announcing the continued existence of a new religious sect : but in no instance, have the walls of the buried cities been found to include a Christian relic.

* The convolvulus of Pliny xxi. 11, may be compared with the Convolvulus sepium.-This plant was seen by Sibthorp in Greece; but appears to have remained unknown in Egypt.

The GRoMphand of Pliny xxvi. 23, may be compared with the Amaranthus tricolor.-The "gelisia" of Hildegard ii. 153, is referred by Sprengel to the same plant. The A. tricolor is figured by Lobel; and according to Graham, is cultivated in the gardens of Hindostan: but it appears to be unknown in Egypt.

$\dagger$ Among these objects, are seeds and fruits; which have been carefully collected, and are now deposited in the museum at Naples; but I am not aware, that any account of them has been published. 
Coins have been discovered, that were issued in Egypt during each year of the reign of Titus; and his name in hieroglyphic characters has been found on temples at Esneh, and at the Oasis of Dakkeh.

In " A. D. 81," the accession of Domitian, the eleventh Roman Emperor, took place. His name occurs in hieroglyphic characters on temples at Philæ, Esneh, and Dendera; on a propylon at Thebes; and on obelisks at Rome and at Benevento, in Italy : coins have been discovered, that were issued in Egypt during each year of his reign.

The First Epistle of Clemens Romanus, one of the earliest Christian writings apart from the New Testament, is usually referred to the reign of Domitian.

In "A. D. 96," the accession of Nerva, the twelfth Roman Emperor, took place. His name has been found in hieroglyphic characters, only on a small temple at Assuan or Syene.

In "A. D. 98," the accession of Trajan, the thirteenth Roman Emperor, took place. His name in hieroglyphic characters has been found on temples at Philæ, Ombos, and Dendera.

In "A. D. 104" (Clinton), Plinius Secundus wrote from his province in Asia Minor respecting the Christians; and his letter, together with the reply of Trajan, is still extant.

The APNABs of Posidonius, Aetius, and Paulus Agineta, is referred by Haller to the "zarnab" of Avicenna; usually considered to be the zeduary (Curcuma zerumbet). - This imported root is mentioned by Macer Floridus and Alpinus : according to Graham, the plant grows in the environs of Bombay.

In "A. D. 115" (according to Clinton), the Martyrdom of Ignatius took place.

In "A. D. 117," the accession of Hadrian, the fourteenth Roman Emperor, took place. His name in hieroglyphic characters has been found on temples at Esneh, Thebes, and Dendera; and on an obelisk at Rome.

In "A. D. 130" (according to coins and an inscription on the Vocal Memnon), Hadrian visited Egypt. At this time, the Christians had become numerous, as appears from one of his letters. During his voyage on the Nile, he founded the Greek city of Antinoe; on a site, which is still marked by ruins in the Roman style of art.

In "A. D. 136," at the close of the Jewish war, Hadrian prohibited the Jews from residing at Jerusalem or in the vicinity; a measure which is supposed to have had some influence on their subsequent destiny. 
In "A. D. 138," the accession of Antoninus Pius, the fifteenth Roman Emperor, took place. His name has been found in hieroglyphic characters on temples at Philæ, Esneh, Thebes, Dendera, and the Oasis El Kargeh; and in Greek inscriptions, in various parts of Egypt.

In "A. D. 152," the first Ecclesiastical Council was held. The meeting took place at Pergamus in Asia Minor; and the opinions of Colarbas were condemned.

In "A. D. 161," the accession of Marcus Aurelius Antoninus, the sixteenth Roman Emperor, took place. His name has been found in hieroglyphic characters at Philæ; together with that of his colleague, Lucius Verus.

The meat fly (Musca vomitoria) is distinctly described by Pausanias x. 28. - The insect has become widely distributed over the globe; and in all probability, is known in Egypt.

The xprcobasanoc of Galen and the "xanthobalanos" of Actuarius and Myrepsus, are referred by F. Adams to the marking-nut, Semecarpus anacardium. - I found this tree abundant in the Central portion of the Dekkan.

The sүкопетсіо brought from Egypt to Galen (De Fac. Simpl. iv.), may be compared with the Solanum Athiopicum. - This plant was seen in Egypt by Delile.

According to Clinton, Christianity was preached in Britain in A. D. 178: the missionaries came from the East; as appears, from their having taught the original mode of observing Easter.

In "A. D. 180," the accession of Commodus, the seventeenth Roman Emperor, took place. His name has been found in hieroglyphic characters at Esneh, and on a small temple at Contra-Latopolis.

In "A. D. 193," the accession of Pertinax, the eighteenth Roman Emperor, took place. His name has been found on coins, issued in Egypt during his three months' reign. The name of his successor, Didius Julianus (whose reign was equally brief), has not been found on the Egyptian monuments: but that of Pescennius Niger, an unsuccessful aspirant in Egypt, has been discovered in hieroglyphic characters by Lepsius.

In the same year, the accession of Septimius Severus, the twentieth Roman Emperor, took place. His name is said to occur in hieroglyphic characters at Esneh. During his reign, the colossus of the Vocal Memnon was repaired; and ever afterwards, has remained silent. 
In "A. D. 197" (Clinton), an Ecclesiastical Council was held by Victor at Rome; and the celebration of Easter was, to some extent, disconnected from the Jewish Passover: the innovation was not adopted by the Asiatic churches.

In "A. D. 211," the accession of Caracalla, the twenty-first Roman Emperor, took place. His name, and that of his brother Geta, have been found in hieroglyphic characters at Esneh. The name of Caracalla occurs also in a Greek inscription in the quarries at Philæ.

In "A. D. 217," the accession of Macrinus, the twenty-second Roman Emperor, took place. His name has been found on coins issued in Egypt.

In "A. D. 218," the accession of Elagabalus, the twenty-third Roman Emperor, took place. His name has been found on coins issued in Egypt.

Philostratus iii. 5, states, that Apollonius Tyanaeus "saw in India some of those nuts which in Greece are kept in the temples as curiosities." The cocoa-nut (Cocos nucifera) appears to be also mentioned by Cosmas Indicopleustes; and is clearly the "karyon megiston ton indikon" of the Pseudo-Callisthenes iii. 8, and Julius Valerius.Cocoa-nuts are said to be noticed in the Itinerary of Abuzeid and Wahab, and by Rhazes, Haly Abbas, Mesue, and Avicenna; I saw in Egypt a quantity that had been imported by the route of Mecca and the Thebaid.

According to Beckmann, Philostratus alludes to the dourra (Sorghum vulgare) as seen in India by Apollonius Tyanaeus: and Heliodorus is considered (by Delile) to refer to its growing at Meroe. I have not found the dourra figured on the Egyptian monuments; but stems intermingled with those of the papyrus, were shown me in a parcel exhumed at Saccara, possibly as ancient as the Coptic Period.-The dourra is mentioned by Ibn Masah, Abu Hanifa, Rhazes, and Ibn Baitar, under its Indian name "jawars :" its cultivation in Egypt is noticed by Alpinus, and by all subsequent travellers.

In " A. D. 222," the accession of Alexander Severus, the twentyfourth Roman Emperor, took place. His name has been found in a Greek inscription at Antinoe.

In "A. D. 235," the accession of Maximinus, the twenty-fifth Roman Emperor, took place. His name has been found on coins issued in Egypt.

In “A. D. 238," the accession of Pupienus Maximus, the twenty- 
sixth Roman Emperor, took place. His reign lasted only a few months; but his name has been found on coins issued in Egypt.

In the same year, the accession of Gordianus Pius, the twentyseventh Roman Emperor, took place. His name has been found on coins issued in Egypt. Inscriptions dated in his reign, commemorating acts of adoration by Egyptian families towards the ancient deities, are mentioned by Champollion-Figeac.

The kanakangor of Democritus, Paxamus, Anatolius Berytius, and the Geoponica xiii., according to Sibthorp's account of the Greek usage, is the Cnicus benedictus.-This plant was seen by Hasselquist at Damietta.

In "A. D. 244," the accession of Philippus, the twenty-eighth Roman Emperor, took place. He was by birth an Arab, and nominally a Christian. His name has been found on coins issued in Egypt: and (according to Champollion-Figeac) some inscriptions in the above series, dedicated to the ancient deities of Egypt, are dated in his reign.

The Celebration of the Thousandth anniversary of the building of Rome, took place "in the third consulship of Philippus, that is, in A. D. 248," as determined by coins; but the exact month has not been ascertained (Ramsay, in Smith's Biog. Dict.). It appears, however, that Varro's Computation was the one followed.

In "A. D. 249," the accession of Decius, took place. He is the last Roman Emperor whose name has been found in hieroglyphic characters.

In "A. D. 251," the accession of Trebonianus Gallus, the thirtieth Roman Emperor, took place. His name has been found on coins issued in Egypt.

In "A. D. 253-4" (Ramsay, in Smith's Biog. Dict.), the accession of Aemilianus, the thirty-first Roman Emperor, took place. His reign lasted a few months only; but his name has been found on coins issued in Egypt. He was succeded by Valerianus; whose name has also been found on coins issued in Egypt.

On the capture of Valerianus by the Persians, "A. D. 260," his son and colleague, Gallienus, became the sole Roman Emperor. The name of Gallienus has also been found on coins issued in Egypt.

The medicinal кокалог seeds of Aretaeus, may be compared with cocculus Indicus (Menispermum cocculus).-In Egypt an indigenous species of Menispermuin is called "lebakh el-gebel;" and the drug 
"lehibach," as described by Rhazes and Avicenna, seems to correspond in its properties with cocculus Indicus. The M. cocculus, according to Graham, grows in the environs of Bombay.

About this time, according to Gesenius and others, the Hebrew letters now in use, first make their appearance: the earliest inscriptions hitherto discovered, being those at Palmyra. - The "vowel-points" were introduced more than two centuries later; and after the time of Jerome.

About the same time, according to Zoega and others, the Greek letters with some additions, were first employed in writing the Coptic language.-With one exception, all the so-called Coptic inscriptions and manuscripts hitherto discovered, have proved to be Christian: few of them (according to Champollion-Figeac, p. 228) are older than the Seventh century; and they continue down to the final extinction of the language and literature, in the Sixteenth century.

In "A. D. 268," the accession of Aurelius Claudius, the thirtyfourth Roman Emperor, took place. His name has been found on coins issued in Egypt.

In "A. D. 269" (Clinton), Queen Zenobia of Palmyra invaded Egypt; and for some months, retained possession of the country.

In "A. D. 270," the accession of Aurelianus, the thirty-fifth Roman Emperor, took place. His name has been found on coins issued in Egypt: as also, the name of Domitianus, an unsuccessful aspirant. From this time (according to Zoega, Tochon, and Sharpe), all traces of the precious metals disappear from the Egyptian coinage. With the exception, that in one or more instances, the Roman Legion in Egypt coined silver into money for their own pay.

According to Sharpe, the Church of St. Mary was built at Alexandria during the reign of Aurelianus; and the first public service of Christianity in Egypt, was probably held within its walls.

In "A. D. 275," the accession of Tacitus, the thirty-sixth Roman Emperor, took place. His name has been found on coins issued in Egypt. He was succeeded by Florianus; whose authority was not acknowledged in the East, and whose name has not been found on the Egyptian monuments.

In "A. D. 276," the accession of Probus, the thirty-eighth Roman Emperor, took place.

In "A. D. 282," the accession of Carus, the thirty-ninth Roman 
Emperor, took place. His name has been found on coins issued in Egypt.

In "A. D. 283," the accession of Carinus, the fortieth Roman Emperor, took place. His name has been found on coins issued in Egypt: as also the name of his colleague, Numerianus.

In " A. D. 284," the accession of Diocletian, the forty-first Roman Emperor, took place. The great syenite column, so conspicuous at Alexandria, according to a Greek inseription on its base, was erected during the reign of Diocletian.

In "A. D. 299" (Clinton), the separate Egyptian coinage ceased: from this time, the coins issued at Alexandria bear Latin inscriptions, and are similar in every respect to those of the rest of the Empire.

In “A. D. 303," Diocletian issued his celebrated edict against the Christians : supposed, to have been in part extorted from him through the intrigues of Galerius.

In "A. D. 305," the abdication of Diocletian and the accession of Constantius, took place.

In "A. D. 306," the accession of Constantine, the forty-third Roman Emperor, took place. During his reign, all religions were tolerated, and the persecutions of the Christians finally ceased. The founding of the oldest existing monasteries of Egypt, is attributed by the Coptic monks to the Empress Helena, the mother of Constantine.

The progress of Christianity appears to have been more rapid in Egypt than in any other country: and after the Conversion, the rearing of temples by princes ceased. In the Thebaid, however, are remains of churches, abundantly proving that architectural taste was not extinct; evidence also, that the Early Christians did not destroy antiquities; and abandoned Christian villages, which show more refinement in the style of living than prevails in the same district at the present day.

In "A. D. 325" (Alsted), the first General Ecclesiastical Council was held. The meeting was convened at Nice, in Asia Minor: and nearly one hundred Egyptian and Lybian bishops are said to have been present.

In “A. D. 330" (Idatius, quoted by Plate, in Smith's Biog. Dict.), Constantine removed the seat of government from Rome to Byzantium or Constantinople. To which city, he also transported an obelisk from Egypt. 
Birch speaks of mummies "as late as the time of Constantine, if not indeed a century later."

In "A. D. 337," Constantine, in the daily expectation of death, declared his intention of becoming a Christian, and received baptism. In the same year, he was succeeded by Constantius II.

In "A. D. 341" (Clinton), a law was promulgated against the ancient religious rite of sacrifices.

The cultivated костос of Damogeron, of the Capitularia of Charlemagne, and the Geoponica vii. 13 and xi. 27, according to Forskal's account of the Greek usage, is the Balsamita vulgaris.-This plant was. seen by Forskal and Delile in gardens at Cairo.

In " A. D. 357," Constantius II. visited Rome: and by his direction, an obelisk (the same now called the "Lateran obelisk") was brought to that city from Egypt.

In "A. D. 361," the accession of Julian, the forty-fifth Roman Emperor, took place : and ancient Heathenism once more, and for the last time, became the religion of the State. Julian, however, permitted the Jews to make an attempt to rebuild their temple at Jerusalem; and in fact tolerated all religions.

In "A. D. 363," the accession of Jovian, the forty-sixth Roman Emperor, took place. He declared himself a Christian; and issued an edict, placing Christianity upon a legal basis : at the same time, he equally protected the followers of the ancient religion.

In "A. D. 364," the accession of Valentinian, the forty-seventh Roman Emperor, took place. He took up his residence in Italy, and gave the Eastern portion of the Empire to his brother Valens.

The tarpenedac, an Indian animal mentioned in the Pseudo-Callisthenes iii. 17, may be compared with the buffalo (Bos bubalus).This important domestic animal was introduced into the Mediterranean countries some centuries later. It is mentioned by Eltamini and Allatafet; and is now extremely common in Egypt.

In "A. D. 375," the accession of Gratian, the forty-eighth Roman Emperor, took place. From this time, religious liberty was no longer permitted; but the Christians, gaining the ascendency, began to exercise persecutions towards the followers of the ancient religion, and towards certain sects of their own body. 
In "A. D. 379," after the death of Valens, Gratian appointed Theodosius to rule over the Eastern portion of the Empire.

In "A. D. 383," the death of Gratian took place; and Valentinian II., being supported by Theodosius, became the acknowledged Roman Emperor.

The formal Destruction of the temples, had not commenced in "A. D. 384" (as appears from Libanius): soon, however, orders of Theodosius were directed against particular temples; and these were demolished by soldiers, aided by bands of fanatics.

In "A. D. 390" the great temple of Serapis at Alexandria was demolished. This building contained the Alexandrian Library (see Tertullian Apolog. 18, and Orosius vi. 15).

On the death of Valentinian II., "A. D. 392," the Empire became united under Theodosius; now in the regular series, the fiftieth Roman Emperor.

In "A. D. 395," Theodosius, shortly before his death, divided the Empire between his two sons, Arcadius and Honorius. This partition proved to be final ; for the community of interest hitherto felt in regard to foreign invasions, was at this time greatly weakened. Arcadius thus became the head of the Byzantine branch of the Roman Empire.

According to Rhazes, The "khiar janbar," or Cassia fistula, is mentioned by Priscianus. - The medicinal use of the pods, is noticed by Maserjawia, Ibn Masawia, Ibn Gnefith, Haly Abbas, Actuarius, and Nicolaus Myrepsus: A. A. Elnabati, Ibn Baitar, and Belon, allude to the presence of the tree in Egypt: where it is still common in gardens; and where, nevertheless, there is a large importation of the pods by the way of Yemen.

In "A. D. 408," the accession of Theodosius II., the second Byzantine emperor, took place. He zealously prosecuted the work of demolishing the temples of the ancient religion : a disastrous measure, in respect to Monumental History.

The "naphri" of the Coptic Version of Matthew xiii. 31, may be compared with "el-nefyr," the current Egyptian name of the Datura metel.-This plant was seen in Crete by Belon; is figured by Matthioli ; and was doubtless originally derived from India. The $D$. fastuosa, by some writers considered as only a variety, was seen in Egypt by Delile.

In "A. D. 450," the accession of Marcian, the third Byzantine emperor, took place. 
In “A. D. 451," the fourth General Ecclesiastical Council was held, at Chalcedon; and the opinions of Eutyches were condemned. This was equivalent to an excommunication of Egypt; where these opinions were general, and where they prevail to the present day.About a century after the condemnation, the proscribed sect received the name of "Jacobites," from Jacobus of Edessa (pronounced Yacobus); and hence apparently, the origin of the term "Copts," applied by Europeans to the Christian portion of the population of Egypt.

In "A. D. 457," the accession of Leo, the fourth Byzantine emperor, took place. He was crowned by a priest; an innovation afterwards adopted by all Christian sovereigns.

In "A. D. 474," the accession of Leo II., the fifth Byzantine emperor, took place: his reign lasted a few months only; and before the close of the year, he was succeeded by Zeno.

In “A. D. 482," Zeno issued an edict, called the Henoticon or Union; in effect, allowing the Egyptians some liberty in choosing their own creed.

The cantaAon of Aetius, is doubtless sandal-wood (Santalum album).-This odoriferous wood is mentioned by Rhazes and Avicenna ; and Serapion states, that it is brought from China. The living plant, according to Clot-Bey and Figari, has been recently introduced into Egypt.

According to Greenhill, Mocxoc or musk, is mentioned by Aetius; and the deer-like animal from which it is obtained (Moschus moschiferus), by Cosmas Indicopleustes. - The musk animal, known to inhabit Thibet, is distinctly described by Abu Hanifa (as quoted by Serapion). Ibn Masawia, Honain, and Symeon Sethus, speak of the imported perfume; and its sale in Egypt is noticed by Leo Africanus.

In "A. D. 491," the accession of Anastasius, the seventh Byzantine emperor, took place. He adhered to the policy of his predecessor, in refusing to enforce the decrees of the Council of Chalcedon; and the Western Empire having ceased to exist, he was anathematized by Pope Symmachus. This is perhaps the earliest instance of the papal influence being directed against a king.

In "A. D. 518," the accession of Justin, the eighth Byzantine emperor, took place. He adopted energetic measures against the Eutychians, in conformity with the decree of the Council of Chalcedon.And this became the settled policy of his successors.

In "A. D. 525" (Alsted), Dionysius Exiguus, a Scythian monk, 
first suggested the use of the Christian Era, and set the example in his writings. The practice was gradually adopted by European nations; but the ancient computation has remained uninterrupted in Egypt.

In "A. D. 527," the accession of Justinian, the ninth Byzantine emperor, took place. He built the fortified monastery on Mount Sinai ; and established intercourse with Abyssinia. At this time, corn was carried in Alexandrian ships to Cornwall in Britain, and exchanged for tin (Leontius, Acta Sanct. Jan. xxiii.)

According to Sharpe, Under Justinian, some traces of a separate Egyptian coinage again make their appearance. The inscriptions are still in Latin; but the abbreviated name of Alexandria is in Greek letters, and the system of weights is different from that of Constantinople.

The Aртүтікн of Alexander Trallianus, according to Sibthorp's account of the Greek usage, would seem to be one or more species of Scabiosa.-The Scabiosa prolifera, was seen by Sibthorp in the cultivated fields of Cyprus; and was received from Egypt by Willdenow.

The manufacture of silk was unknown in the Mediterranean countries prior to "A. D. 551;" when living silk-worms were brought from Eastern Asia (see Theophanes Byzantius, quoted by Photius, Bibl. cod. 64).

The silk-worms were of course accompanied by the white mulberry (Morus alba) : a species evidently unknown to Pliny, who enumerates the mulberry among "the berries that in the end turn black."-The white mulberry, has long been an object of cultivation in Egypt.

An opinion prevailed in ancient times, that Lower Egypt is exempt from earthquakes: but the Earthquake of "August, A. D. 554," is described by Agathias, as felt by him at Alexandria.-Modern travellers also speak of experiencing earthquakes in Egypt.

In "A. D. 565," the accession of Justin II., the tenth Byzantine emperor, took place. Among the events of his reign, he entered into an alliance with the "Toyrkoi" or Turks; now for the first time mentioned (see Menander Protector, Theophanes Byzantius, and Joannes Epiphaniensis).

In "A. D. 578," the accession of Tiberius Constantinus, the eleventh Byzantine emperor, took place.

In “A. D. 582," the accession of Mauricius, the twelfth Byzantine 
emperor, took place. He protected and encouraged learning and the arts.

In reference to the condition of Northern Europe it may be observed, that Clovis, the first Christian king of France, began to reign in the same year (see Clinton).

In "A. D. 602," the accession of Phocas, the thirteenth Byzantine emperor, took place.

In "A. D. 610," the accession of Heraclius, the fourteenth Byzantine emperor, took place.

In Egypt, according to Forskal, the Coix lachryma is called "dima Ayoub." This being a Coptic name, with a Scriptural allusion, seems to indicate, that the plant was known to the Early Christians. The C. lachryma is figured by Dodonæus: it is a Tropical production, derived from India, or perhaps originally from the Malay countries.

In "A. D. 616," the Persians once more invaded Egypt; captured Alexandria, where they established themselves; and retained possession of the country for ten years.

According to Sharpe, About this time, Thomas, a Syrian bishop, came to Alexandria, to correct the Syriac Version of the New Testament, made about a century before by Philoxenus. He compared the gospels with three Greek manuscripts in the monastery of St. Anthony : and his corrected Edition, is the last effort in sacred criticism attempted at Alexandria, or in any part of the East.

The RHEUM BARBARUM of Isidorus Hispalensis, is referred by Sprengel to the medicinal rhubarb.-This drug is also mentioned by Rhazes, Mesue, Averrhoes, and Ibn Baitar: it is brought by the caravans from Interior Asia; and Barthema (or Vertoman) speaks of the sale of rhubarb in Korasan.

According to Kasimirski's Version, the banana (Musa sapientum) is mentioned by Mohammed, in the Koran. - The plant is noticed by Avicenna, Serapion, and Leo Africanus; and was seen by the early Portuguese Pilot, both at St. Thomas in the Gulf of Guinea, and at Alexandria. I found the banana growing in the open air at Madeira and Malta, and ripening its fruit at Alexandria; and am informed by Mr. Nuttall, that it does so in certain situations even at the Azores.

According to Kasimirski's Version, the tamarind (Tamarindus Indica) is mentioned in the Koran xxxiv. 15. - Cailliaud states, that tamarind pods are imported in quantities by the Darfour caravans: 
the living tree, as appears from Belon, Alpinus, Delile, and others, has been repeatedly introduced into Egypt.

The "zakkoum oil" of the Koran xxxvii. 60, and of Modern Palestine, may be compared with the oil obtained from the fruit of the Elocodendron argan. - This is an indigenous tree of Morocco; but there are reasons for supposing, it may also grow in Palestine.

According to F. Adams, The nutmeg (Myristica moschata), a production of the Molucca Islands, is mentioned by Ahrun, Isaac Ibn Amran, Ibn Masawia, Miseaben, Albasari, Rhazes, Avicenna, and Serapion.

Among the articles found in ancient Egyptian tombs, some may have been deposited as far back as the Coptic Period. According to Wilkinson, seeds of the Cyperus esculentus, have been discovered in these tombs. - The plant was seen by Delile, growing spontaneously at Rosetta.

According to Wilkinson, leaves and fragments of senna, have been found in ancient Egyptian tombs. The species is not given; but all the senna seen by myself in the warehouses of Mocha and Muscat, belonged to Cassia lanceolata.-The drug senna, is said to be mentioned by Isaac Ibn Amran, Abix, Serapion Senior, Rhazes, Haly Abbas, and Mesue. The C. lanceolata was seen by Delile, growing on the borders of Nubia.

According to Champollion-Figeac (Egypte Anc. p. 175), pods of the Acacia heterocarpa have been found in ancient Egyptian tombs.Delile met with pods in the drug shops of Cairo; and with the living tree, near Kosser in Upper Egypt.

According to Champollion-Figeac, fruit of the Mimusops elengi has been found in ancient Egyptian tombs.-The tree, according to Graham, is a favourite with the Muslims of India.

\section{THE EARLY MUSLIM PERIOD.}

In "A. D. 640" (Marcel), shortly before the death of Heraclius, the Muslims under Amru (the general of Khalif Omar) invaded Egypt and obtained possession of Alexandria. They appear to have been hailed as deliverers of the country from a foreign yoke.

I have hitherto deferred speaking of a subject, which will be found to throw light on many historical events: viz., the disposal of the collective agricultural produce of Egypt. To go no further back than 
the time of Xerxes, the corn of Egypt was indispensable to his designs against Greece (Herodotus vii. 25). It fed armies ; and in the days of Josephus (Bell. Jud. iv. 10, 5), formed an element in making and unmaking Roman emperors. The circumstance is therefore worthy of note, that after the Muslims entered Alexandria, European rulers no longer had control over the corn of Egypt.

From this time, also, Egypt appears as if withdrawn from the knowledge of Europeans for nearly a thousand years. But during the greater part of this interval, Europe supplies very little information respecting her own condition. The Greeks and Romans being excepted, the remaining European nations hardly possess records of their own as ancient as the origin of the Muslim religion; and the popular mind rarely goes beyond the limits of the National Literature.

The Pilgrimage to Mecca obviously tended to increase the commercial intercourse between India and Europe; and this intercourse, it should be observed, everywhere remained in the hands of the Muslims. There was indeed some choice of routes for the general objects of traffic; but the living Tropical plants, perhaps without exception, reached the Mediterranean by the way of Egypt.

In "A. D. 643" (Clot-Bey), the mosque of Amru was built at Fostat, near Cairo ; but "having undergone frequent repairs, a very small portion of the original edifice remains." This and another mosque built by Amru at Assuan, present the usual round arches then in vogue in Greece and Italy (Wilkinson, Thebes and Egypt, pp. 310 and 455). In other respects, a striking change is manifest in the monumental history of Egypt: representations or images of external objects, * whether living or inanimate, are from this time carefully avoided; a circumstance, which on many accounts bas proved fortunate for Antiquarian research.

In "A. D. 644," the accession of Khalif Othman, the second Muslim ruler of Egypt, took place.

In “A. D. 651" (Plate, in Smith's Biog. Dict.), the Muslims fitted out a naval expedition against Sicily; and also captured Rhodes; on which occasion, the celebrated colossus was sold and broken up.

In “A. D. 655" (Plate, in Smith's Biog. Dict.), the Greeks were defeated in a naval combat by the Muslims.

In "A. D. 656," the accession of Khalif Ali, the third Muslim ruler

* A remarkable exception is made in favour of the heavenly bodies, the moon and the stars. 
of Egypt, took place. Copper coins, supposed to have been issued under the legitimate khalifs, are figured by Marcel, p. 26.

On the death of Khalif Ali, "A. D. 661," Mu'awiyah, of the family of Ommiah, became ruler of the Muslim Empire. He removed the seat of government from Medina to Damascus.

In “A. D. 672" (Plate, in Smith's Biog. Dict.), the Muslim fleet, after capturing Smyrna and most of the Greek islands, began the blockade of Constantinople: and on this occasion, Greek fire, just invented by Callinicus, was successfully employed in the defence.

In "A. D. 680," the accession of Yezid, the second Ommiad khalif, took place.

In "A. D. 683," the accession of Mu'awiyah II., the third Ommiad khalif, took place. His reign was brief; and in the following year, he was succeeded by Merwan.

In "A. D. 685," the accession of Abd-el-Melek, the fifth Ommiad khalif, took place. During his reign, a Nilometer was constructed at Helwan, near Cairo (Wilkinson, Thebes and Egypt, p. 541).

The "fawfal" of Maserjawia, Ibn Amran, Abu Hanifa; Mesue, Avicenna, Serapion, and Ibn Baitar, is admitted to be the nut of the betel palm (Areca catechu).-This palm is extensively cultivated throughout Hindostan and the Malay countries: Wilkinson speaks of "areca" nuts being found in ancient Egyptian tombs.

The "tamul" or "tanbul" of Maserjawia, Abu Hanifa, Masudi, Haly Abbas, Avicenna, and Ibn Baitar, is admitted to be the betel pepper (Piper betel). - The use of betel has never been extended to Egypt; where, indeed, the Piper betel could hardly be cultivated with success.

The "turbud" of Maserjawia, Ibn Masawia, Hobaisch, Rhazes, Haly Abbas, Mesue, Avicenna, and Serapion, is considered to be turpeth; the imported root of Convolvulus turpethum. - The plant, according to Graham, is common in the environs of Bombay.

The "kilkil" (already mentioned) of Maserjawia, Ibn Masawia, Abu Hanifa, Rhazes, Avicenna, and Ibn Baitar, according to the received opinion and Forskal's account of the usage in Yemen, is the Cassia tora. - This plant has become a very general weed in Tropical countries; and the seeds (which according to Ainslie are used medicinally in India) have doubtless been sometimes imported into Egypt.

The "cafur" of Maserjawia, Meseab, Mesarguil, Ibn Masawia, Ibn Amran, Rhazes, and Serapion, is clearly camphor; imported from 
China, and the product of Laurus camphora.-Symeon Sethus, according to Alpinus (De bals. 5), speaks of the oil of camphor: the living tree, according to Clot-Bey and Figari, has been recently introduced into Egypt.

According to Marcel, copper money only had been coined by the Muslims before the reign of Abd-el-Melek; who first coined silver, to the exclusion of Greek and Persian coins. Marcel, p. 34, figures one of the coins issued by Abd-el-Melek, bearing the date of the 79th year of the Hejra (A. D. 698) : by some writers, this is considered the earliest Muslim coin hitherto discovered.

In "A. D. 705," the accession of Walid, the sixth Ommiad khalif, took place. During his reign, the mosque El-Djame el-Atyk was commenced near Cairo: he also issued coins (see Marcel, p. 34).

The велілег of Zosimus Panopolitanus, Mesue, and Chariton, is admitted to be belleric myrobalans; the fruit, according to Royle, of Terminalia belerica. - This tree was seen by Graham, growing in the environs of Bombay.

The амвАвг of Zosimus Panopolitanus, Rhazes, Mesue, Chariton, and Nicolaus Myrepsus, is admitted to be emblic myrobalans (the fruit of Emblica officinalis).-Edrisi speaks of the importation of myrobalans by the way of Aden; and the medicinal use of emblic myrobalans by the Egyptians, is mentioned by Alpinus. According to Bontius, the E. officinalis grows wild in Java; and Graham met with it, also wild in Hindostan.

In "A. D. 710," by the permission of Khalif Walid, the Muslims entered Spain. About the same time, their armies in the East entered Hindostan, and the country of Kaschgar in Central Asia.

In " A. D. 715," the accession of Soliman, the seventh Ommiad khalif, took place. The Nilometer at Rhoda, near Cairo, was built during his reign; it affords evidence, that round arches were still in vogue.

In "A. D. 717," the accession of Omar II., the eighth Ommiad khalif, took place.

In "A. D. 720," the accession of Yezid II., the ninth Ommiad khalif, took place.

In "A. D. 724," the accession of Hescham, the tenth Ommiad khalif, took place. Coins, issued during his reign, are figured by Marcel, p. 38.

In “A. D. 732," the Muslims, after having overrun a large portion 
of France and advancing as far as the Loire, were defeated by Charles Martel : shortly afterwards, they were obliged to retire into Spain.

In "A. D. 743," the accession of Walid II., the eleventh Ommiad khalif, took place.

In "A. D. 744," the accession of Yezid III., the twelfth Ommiad khalif, took place. He was succeeded by Ibrahim; and before the close of the year, by Merwan II., the fourteenth and last Ommiad khalif.

In “A. D. 7500," Abu'l Abbas, of the family of Abbas, became ruler of the Muslim Empire: and the seat of government was removed from Damascus to a town on the Euphrates. The change was accompanied with the loss of Spain; which became an independent Muslim kingdom.

In "A. D. 754," the accession of El-Mansur, the second Abbassid khalif, took place. Coins, issued during his reign, are figured by Marcel, p. 44.

According to Beckmann, the hop (Humulus lupulus) is mentioned in a letter of dotation of Pepin, king of France; and also by Adelard.The plant was seen by Belon at Constantinople; and according to ClotBey and Figari, was introduced into Egypt by Delile.

In "A. D. 762" (Marcel), Khalif El-Mansur founded the city of Bagdad, near ancient Babylon, for the new seat of government.

In "A. D. 775," the accession of El-Mahadi, the third Abbassid khalif, took place. Coins, issued during his reign, are figured by Marcel, p. 45.

According to F. Adams, Kebulic myrobalans (the fruit of Terminalia Chebula) are mentioned by Sarac the Indian, Honain, Rhazes, Mesue, Avicenna, Serapion, Actuarius, and Nicolaus Myrepsus. - Alpinus speaks of the medicinal use of these nuts in Egypt: according to Graham, the tree grows wild in the environs of Bombay.

In "A. D. 784," the accession of El-Hadi, the fourth Abbassid khalif, took place.

In "A. D. 786," the accession of Harun-el-Rashid, the fifth Abbassid khalif, took place. He protected and encouraged literature and science; and his memory has also been cherished for his benevolent acts. Coins, issued during his reign, are figured by Marcel, p. 48.

The RADIX of the Capitularia of Charlemagne, would seem to be the radish (Raphanus sativus).-The "fujl" of Ibn Masawia, Elthabari, Costus, Rhazes, and Ibn Baitar, according to Egyptian usage, is the 
radish : at the present day, the plant is abundantly cultivated throughout the Arab countries, to the Dekkan inclusive.

The AMEUM of the Capitularia of Charlemagne, has been referred to the Ammi majus. - This plant was seen by Sibthorp in Greece; by Hasselquist in Palestine; and by Delile, growing spontaneously at Alexandria.

The DRAGONTEA of the Capitularia of Charlemagne, and the "tharkhun" of Ibn Masawia, Abu Hanifa, Rhazes, Avicenna, Symeon Sethus, and Ibn Baitar, are admitted to be the tarragon (Artemisia dracunculus).-This plant was seen in Egypt by Hasselquist.

The tANARITA of the Capitularia of Charlemagne, is considered to be the tansy (Tanacetum vulgare).-This plant is figured by Dalechamp; and is mentioned by Lobel, as cultivated in the English gardens. It was not seen in Greece by Sibthorp; and according to Clot-Bey and Figari, has been only recently introduced into Egypt.*

The millefolium of a medical formula of the time of Charlemagne, and of Macer Floridus 58, is probably the yarrow (Achillea millefolium). - This is a Northern plant; noticed by Lobel; not seen in Greece by Sibthorp; and according to Clot-Bey and Figari, only recently introduced into Egypt.

In "A. D. 809," the accession of El-Amin, the sixth Abbassid khalif, took place.

In "A. D. 813," the accession of El-Mamun, the seventh Abbassid khalif, took place. He protected and encouraged literature and science; was himself an astronomer; and by his direction, a degree of Latitude was measured. Coins, issued during his reign, are figured by Marcel, p. 51.

The "khawlanjan" of Ibn Masawia, Ibn Amran, Rhazes, Avicenna, and Serapion, and the "galanga" of Macer Floridus 70, and Nicolaus Myrepsus, are admitted to be galanga; the aromatic root of Alpinia galanga.-The plant grows wild in Hindostan; and Alpinus speaks of the medicinal use in Egypt of the imported root.

The "badinjan" of Ibn Masawia, Rhazes, Avicenna, Serapion, Ibn Baitar, and Makrisi, according to Egyptian usage, is the egg-plant (Solanum melongena). - At the present day, the egg-plant is abundantly cultivated in Egypt.

* The nepeta of the Capitularia of Charlemagne, and of Walafridus Strabus, is considered to be the Nepeta cataria. - This plant, according to Sprengel, is figured by Brunfels. It was seen by Sibthorp at Constantinople; but appears to bave remained unknown in Egypt. 
The "kababat" of Ibn Masawia (as quoted by Haller), Honain, Rhazes, Serapion, and Ibn Baitar, is considered to be cubebs (Piper cubeba).-This kind of pepper is said to grow wild in Java.

The "lebleb" of Ibn Masawia, Ibn Amran, Alkanzi, Haly Abbas, and Serapion, according to Egyptian usage, would seem to be the Dolichos lablab. - Alpinus, Forskal, and Delile, found this plant cultivated for ornament in Egypt and Nubia.

In "A. D. 832" (Marcel), Khalif El-Mamun visited Egypt: he caused the Nilometer at Rhoda to be repaired; and Kufic inscriptions sculptured on the building by his orders, are mentioned by Marcel. According to Wilkinson, some of the Kufic inscriptions at Assuan are very nearly as ancient (Thebes and Egypt, p. 455).

In "A. D. 833," the accession of Motassem, the eighth Abbassid khalif, took place. Coins, issued during his reign, are figured by Marcel, p. 53. About this time, the Muslims obtained possession of Sicily; where they maintained themselves for more than two centuries.

The "sibistan" of Honain, Rhazes, Avicenna, Serapion, and Ibn Baitar, is admitted to be one or both species of Cordia. The C. myxa has been already noticed. The Cordia crenata is likewise a Tropical tree, introduced into and successfully cultivated in Egypt.-Where it was seen by Alpinus and Delile.

The "dend" of Honain, Hobaisch, Rhazes, Serapion, and Ibn Baitar, is referred by Royle to the Croton tiglium. - This plant grows in Hindostan; but according to Alpinus and Delile, the imported seeds are sold in the drug shops of Cairo.

The "thalisfar" of Honain, Ibn Amran, Avicenna, Elhuri, and Ibn Baitar, is referred by Royle to "the highly aromatic leaves of Rhododendron lepidotum."-This is an indigenous plant of the Himalaya mountains.

In "A. D. 842," the accession of Wathek, the ninth Abbassid khalif, took place.

According to F. Adams, nux vomica (considered to be the seeds of Strychnos nux-vomica) is mentioned by Abram, Haly Abbas, Serapion, and Ibn Baitar.-Nicolaus Præpositus (122), speaks of "nucis vomice." The imported seeds were seen by Forskal and Delile in the drug shops of Cairo; and according to Clot-Bey and Figari, the living plant (a native of Hindostan) has been recently introduced into Egypt. 
In " A. D. 847," the accession of Motawakkel, the tenth Abbassid khalif, took place. Some accident having befallen the Nilometer at Rhoda, he caused it to be rebuilt (Marcel, and Wilkinson, Thebes and Egypt, p. 312). Coins, issued during his reign, are figured by Marcel, p. 56.

The "sah" of the Itinerary of Wahab and Abuzeid (who visited China in "A. D. 851"), and of "Mehemet Arabs" and Ramusio, is admitted to be tec (Thea).-This beverage has never been much used among the Arab tribes; a circumstance, that partly accounts for its having so long remained unknown to Europeans.

From Sprengel's remarks, the precious camphor (Dryobalanops) of Sumatra and Borneo would seem to be mentioned in the Itinerary of Wahab and Abuzeid; also, by Ibn Amran, Edrisi, Abulfeda, Bakui, and other Arab writers.

In “A. D. 861," the accession of Montaser, the eleventh Abbassid khalif, took place.

In "A. D. 862," the accession of Mostain, the twelfth Abbassid khalif, took place.

The "athl" of Isaac Ibn Amran, Serapion, and Ibn Baitar, according to Egyptian usage, is Callitris quadrivalvis.-This is a tree resembling the Casuarina, often planted around the Egyptian villages; and according to my Nubian attendant, also found in Dongola.

According to F. Adams, borax (borate of soda) is mentioned by Ibn Amran, Serapion, Ibn Baitar, and in the Susruta.-Saunders and Turner ascertained, that this salt is procured from a lake in Thibet.

In "A. D. 866," the accession of Motaz, the thirteenth Abbassid khalif, took place.

The "yasmin" of I. Ben Masah, Rhazes, Mosih Ben Elhakam, and Ibn Baitar, according to Delile's account of the Egyptian usage, is the Jasminum grandiflorum.-This plant is by some writers considered only a variety of $J$. officinale: also seen by Delile in gardens at Cairo; and by Forskal, both at Cairo and on the mountains of Yemen.

The "khiar" of I. Ben Masah, Hobaisch, Rhazes, Avicenna, Elgafaki, and Ibn Baitar, according to Egyptian usage, is our common cucumber (Cucumis sativus).-The Bengalee name "keera" is nearly identical; a circumstance confirming the received opinion, That the plant was derived from Hindostan.

In " A. D. 869," the accession of Mohtadi, the fourteenth Abbassid khalif, took place. 
In "A. D. 870," the accession of Motamed, the fifteenth Abbassid khalif, took place. His authority was acknowledged by Tooloon; who, having received the appointment of governor of Egypt, had rendered himself really independent. Coins issued in Egypt, bearing the name of Tooloon, are figured by Marcel, p. 66.

The subterranean aqueducts which supply the city of Alexandria with water, were constructed during the administration of Tooloon : but Coptic tradition ascribes the work to Sanutious, or Shenouda, who was at this time Coptic patriarch (Marcel, pp. 61 and 68).

Tooloon built a mosque, on the site selected a century later for the city of Cairo. This mosque, according to two Kufic inscriptions on the walls, was completed in "A. D. 879." It presents the earliest example of the pointed arch, so far as at present ascertained (Wilkinson, Thebes and Egypt, pp. 302 and 457, and Marcel, p. 75).-From this time, very little change has taken place in Mustim architecture. In Egypt, the style became universal; and in all Eastern countries, Muslim constructions are readily distinguished by the dome and the pointed arch. The origin and extension in Europe of the so-called "Gothic Architecture," is connected with the Muslim occupancy of Sicily and Spain.

The "hamdhidh" of Abu Hanifa and Ibn Baitar, according to Delile's account of the Egyptian usage, would seem to be the Oxalis corniculata; though there is some ambiguity in the name.-The plant is figured by Matthioli and by Lobel; was seen by Forskal, both in Egypt and in the mountain region of Yemen; and by Graham, growing as a weed in the environs of Bombay.

The "lebakh" of Abu Hanifa, Avicenna, Soyouty, Ibn Baitar, Abdallatif, and Makrisi, appears to have been seen in Yemen by Forskal (p. 196); but the tree being without fruit or flowers, the species could not be ascertained.

The "abitheran" of Abu Hanifa, Avicenna, A. H. Ellahabali, and Ibn Baitar, according to Delile's account of the Egyptian usage, is the Santolina fragrantissima. - This is an indigenous plant of the Egyptian Desert; but according to Forskal, is dried and sold in the drug shops of Cairo.

In "A. D. 892," the accession of Motadhed, the sixteenth Abbassid khalif, took place.

The "bamiat" of A. A. Elnabati and Ibn Baitar, according to Egyptian usage, is the ochra (Hibiscus esculentus).-This plant is 
figured by Matthioli, Lobel, and Alpinus; and was seen by Forskal, cultivated both in Yemen and Egypt.

In "A. D. 902," the accession of Moktafi, the seventeenth Abbassid khalif, took place.

In "A. D. 904" (Marcel), Moktafi sent an army, and recovered Egypt from the descendants of Tooloon.

The "ball" of Rhazes, Ibn Samhun, Serapion, and Ibn Baitar, may be compared with "bale," the Bombay name (according to Graham) of Egle marmelos. - The fruit of this tree is used medicinally in Hindostan; and Forskal (Mat. Med.) speaks of the importation of "bel Hendi" fruit into Egypt.

The "fel" of Rhazes, Avicenna, and Serapion, according to the usage in Yemen and Egypt (as given by Forskal and Delile), would seem to be the Mogorium sambac.-This plant is figured by Parkinson; and has become common in the green-houses of Europe and America.

The yellow and the red "vars," described by Rhazes as "brought from Yemen and collected upon trees like pounded saffron," may be compared with the "hares" of Forskal, Mimosa tortilis. - Forskal is silent respecting any use made of this indigenous plant of Yemen.

The "isfanaj" of Rhazes, Avicenna, Serapion, Edrisi, and Ibn Baitar, is admitted to be the spinach (Spinacia oleracea).-This plant is figured by Matthioli; and its cultivation in Egypt is noticed by Alpinus, Forskal, and others.

The "ribas" of Rhazes, Mesue (De electuar.), Avicenna, Serapion, Edrisi, and Ibn Baitar, is referred by Royle and others to the Rheum. ribes. This is an indigenous plant of the mountains of Syria and Persia.

The "bahman" of Rhazes, Avicenna, Serapion, and Ibn Baitar, is referred by Sontheimer and others, to the imported roots of Centaurea beher.-The living plant was seen by Rauwolf in Syria; and by Sibthorp in Cyprus: Forskal (Mat. Med.) speaks of the importation into Egypt of "bahman" roots from Greece.

The "lak" of Rhazes, Mesue (Canon univers.), Avicenna, Ibn Elhozar, and Ibn Baitar, is referred by Greenhill and others to lac (Coccus lacca).-This is an insect production, imported from Pegu; and according to Bontius, also found in Java.

The "mulukhia" of Rhazes, Avicenna, Serapion, Ibn Baitar, and 
Allatafet, according to Egyptian usage, is the Corchorus olitorius, or Jews' mallow. - This plant is mentioned by Forskal, Delile, and ClotBey and Figari, as a favourite esculent in Egypt.

According to F. Adams, bezoars are mentioned by Rhazes, Haly Abbas, Avicenna, Serapion, and Ibn Baitar. - Bontius describes bezoars as alvine concretions formed in various quadrupeds, among others, in goats, gazelles, and monkeys.

In "A. D. 908," the accession of Moktader, the eighteenth Abbassid khalif, took place. A coin issued during his reign, is figured by Marcel, p. 90 .

According to Abdallatif, "Seeds of the lemon were brought from India in the three hundredth year of the Hejra (A. D. 912), and were sown in Oman." - The lemon (Citrus acida), according to F. Adams, is mentioned by Dhanvantare, and by the Persian medical writers : and a plant discovered in Hindostan, may prove to be the lemon in its wild state. The cultivated lemon was seen by Vertoman in Yemen; by Alvarez in Abyssinia; and by Forskal, Delile, and others, in Egypt.

The plant referred to by Abdallatif is possibly the lime (Citrus limonum); which, according to Delile's account of the Egyptian usage, would seem to be the "limun" of Ibn Jamia and Ibn Baitar. - The Citrus limonum was seen by Belon at Cairo; and is figured by Parkinson.

According to Abdallatif, "Seeds of the orange were brought in the same year from India, and were likewise sown in Oman."-The "naranj" of Edrisi and Ibn Baitar, according to Egyptian usage, is the orange (Citrus aurantium). Dhanvantare (as quoted by F. Adams), enumerates the orange among "acid fruits;" and seems therefore to speak of the true Citrus aurantium; which is not cultivated in Western Hindostan. Cademosto found the C. aurantium cultivated in Madeira; and Vertoman met with it in Yemen.

In "A. D. 929" (Munk), the Pilgrimage to Mecca was interrupted by the sect of the Karmatians. At this time, lines of partition were becoming more and more obvious in the Khalifate or Muslim Empire.

In "A. D. 932," the accession of Kaher, the nineteenth Abbassid khalif, took place.

In "A. D. 934," Kaher was deposed; and Radi became the twentieth Abbassid khalif. A coin issued during his reign, is figured by Marcel, p. 93. 
Sprengel states, That Abulfadli, Edrisi, Marco Polo, Abulfeda, and Bakui, speak of the importation from the East India Islands and from Zingitana of the wood of Cosalpinia sappan (used in dyeing red); and also, That this wood is called "presillum"* by the Rabbinical writers, and by Matthæus Sylvaticus.-I met with the living plant in gardens at Bombay, and naturalized on the Island of Zanzibar.

In "A. D. 940," the accession of Motaki, the twenty-first Abbassid khalif, took place. His authority was acknowledged by Ikhschid; who, having received the appointment of governor of Egypt, had rendered himself really independent, and had besides extended his authority over Palestine and Syria. Coins issued by Ikhschid, are figured by Marcel, p. 95.

The "ambar" of Haly Abbas, Eltamini, Avicenna, Serapion, Symeon Sethus, Edrisi, and Ibn Baitar, is referred by F. Adams to ambergris.-This perfume is noticed by Paludanus; is brought from the shores of the Indian Ocean; and according to Beale and others, is derived from the sperm whale (Physeter).

The "teil" grass of Haly Abbas, Stephanus, and Michael de Capella, may be compared with the "deyl el-far" of Modern Egypt, Polypogon Monspeliense.-The P. Monspeliense was seen by Forskal and Delile, growing spontaneously at Cairo.

In “A. D. 944," Motaki was deposed; and Mostakfi became the twenty-second Abbassid khalif.

Champollion-Figeac (Eg. Anc. p. 228) speaks of a Coptic inscription, dated in the six hundred and sixty-second year of the Diocletian Era, and in the three hundred and thirty-fourth of the Hejra ; both equivalent to A. D. 945.

In "A. D. 946," Mostakfi was deposed; and Mothi became the twenty-third Abbassid khalif. His authority was aknowledged by the eunuch Kafur, who governed Egypt in the name of the children of Ikhschid (Marcel, p. 97). A coin issued by Khalif Mothi, is figured by Marcel, p. 94 .

According to Wilkinson, The earliest inscription hitherto discovered in the present Arabic letters, occurs at the gold mines of Gebel Ellaka in the Ababdeh Desert ; and bears the date of the "fifth year of Khalif Mostakfi" (Thebes and Egypt, pp. 416 and 545).

\footnotetext{
* On the discovery of America, the name of this wood was transferred to the country
} now called Brazil. 
In “A. D. 950" (Munk), the Pilgrimage to Mecca was again opened.

The HYSSOPUM of Macer Floridus 45, is referred by Baudet to the Hyssopus officinalis. - This is a Northern plant (figured by Tragus and by Stapel, p. 727), which appears to be unknown in Greece and Syria; according to Clot-Bey and Figari, it has only recently been introduced into Egypt.

The BUGLossa of Macer Floridus 34, is referred by Baudet to the Anchusa officinalis.-This is a Northern plant, noticed by Lobel (Nova stirp. adv.); not found in Greece ; and according to Clot-Bey and Figari, only recently introduced into Egypt. Forskal (Mat. Med.) speaks of the medicinal use in Egypt of "anchusa" root, procured through Alexandria.*

On the death of the eunuch Kafur, in "A. D. 968," Abul-Fawaris, the grandson of Ikhschid, a lad of "the age of eleven years," became governor of Egypt (Marcel, p. 97).

At this time, the Khalifate or United Muslim Empire was virtually at an end. But the spiritual authority of Mothi and his Abbassid successors, continued to be very extensively recognised.

In “ A. D. 969," Moez, hereditary ruler of Barbary and claiming to be the true khalif (by descent from Fatimah), sent an army from the West and obtained the government of Egypt: soon afterwards, his authority was acknowledged in Palestine, Syria, and even in Arabia. A coin issued by him, is figured by Marcel, p. 102.

In "A. D. 970" (Marcel), the city of El-Kahira or Cairo, was founded by Djauhar Kaid, the general of Moez, for the new seat of government.

In " A. D. 972" (Munk and Marcel), Moez took up his residence in Egypt. In the same year, Djauhar Kaid commenced the great mosque and college of El-Azhar, in the northeast quarter of Cairo. - This is still the principal Arab University; and Marcel found there, students from Morocco, Astrakan, and Hindostan (Egypte Mod. p. 102).

* The CICUTA of Macer Floridus 65, is perbaps the Conium maculatum.-This plant was seen in Greece by Sibthorp and Bory de St. Vincent; but appears to have remained unknown in Egypt. 
In “ A. D. 975," the accession of Aziz, of the Fatimite Dynasty, the second sultan of Egypt, took place. A coin issued in Egypt during his reign, is figured by Marcel, p. 103. His name has also been found in an Arabic inscription, at the gold mines of Gebel Ellaka in the Ababdeh Desert; accompanied with the date of the fourteenth year of his reign (Wilkinson, Thebes and Egypt, p. 416).

The "kurras" and "anjurat" of Ibn Joljol, and Ibn Baitar, may be compared with the Senecio squalidus.-This plant was seen by Forskal and Delile, growing in the environs of Cairo and Alexandria.

In "A. D. 996," the accession of Hakem, of the Fatimite Dynasty, the third sultan of Egypt, took place. He attempted to found a new religion; and partially succeeded; for he is the prophet of the Druses of Lebanon. According to Wilkinson, he is treated as a prophet in a Kufic inscription over the door of the mosque built by him at Cairo (Thebes and Egypt, pp. 299 and 547). A gold coin issued by him, is figured by Marcel, p. 104.

The "setargi indi" of Mesue (De electuar.), may be compared with "zatar hendi," the Egyptian name of Plectranthus crassifolius.-This plant was seen in Egypt by Alpinus; by Delile, in a greenhouse at Cairo; and Forskal found it cultivated in Yemen.

The "cimini carmeni" of Mesue (De electuar.), according to Egyptian usage, is the Zygophyllum coccineum.-This is an indigenous plant of the Egyptian Desert: according to Forskal (Mat. Med.), the seeds are sold in the drug shops of Cairo.

In "A. D. 1021," the accession of Daher, of the Fatimite Dynasty, the fourth sultan of Egypt, took place. A gold coin issued by him at Cairo, is figured by Marcel, p. 105.

Avicenna speaks of the medicinal use of the "diwdar," obtained from the Himalaya pine, Pinus deodara.-The drug in question, has doubtless been sometime imported into Egypt.

The "yellow-flowered jasmine" of Avicenna and Serapion, may be compared with the Jasminum odoratissimum.-This plant appears to be unknown in Egypt; and is supposed to be a native of Madeira: but we should hardly look for Tropical forms in the Madeira vegetation.*

The "blue jasmine" of Serapion, is referred by Parkinson to the

* According to Sprengel, Avicenna speaks of bread made from the Canarium commune at Macassar (in the Island of Celebes); and Rumphius' account corresponds.-I have met with no notice of the importation of a product of this plant into Egypt. 
lilac (Syringa vulgaris.) - Parkinson quotes Alpinus; but otherwise, I do not find the lilac mentioned as existing in Egypt: indeed, it is not successfully cultivated as far South in the United States. According to Matthioli, the plant was brought into Italy from Constantinople.

In "A. D. 1036," the accession of Mostanser, of the Fatimite Dynasty, the fifth sultan of Egypt, took place. Gold coins issued by him, are figured by Marcel, p. 118.

In "A. D. 1046" (Marcel, p. 106), the mosque of Amru, at Fostat near Cairo, was repaired by the orders of Mostanser.

In “A. D. 1065" (Marcel), Count Roger of Normandy, engaged in expelling the Muslims from Southern Italy, took advantage of a civil war in Sicily among the Muslim population, and obtained the rule of the island. - Coins issued by the Norman kings of Sicily, bearing bi-lingual inscriptions, Latin and Arabic, are figured by Marcel, p. 120.

The "arjan" of Ibn Redwhan and Ibn Baitar, may be compared with the "arjuna" of Hindostan, Pentaptera arjuna.-This is an indigenous tree; but according to Gibson and Graham, the bark is used medicinally, and is sold in the drug shops of India.*

In "A. D. 1092," the Nilometer at Rhoda was repaired; as appears from Karmatic inscriptions on the building, copied and published by Marcel, p. 116.

In "A. D. 1094," the accession of Mostaali, of the Fatimite Dynasty, the sixth sultan of Egypt, took place.

The "aatharilal" of Elzaharawi, Edrisi, and Ibn Baitar, may be compared with the Toritis anthriscus. - This plant was seen by Sibthorp in Greece; and by Forskal and Delile, growing spontaneously at Rosetta and Cairo.

In "A. D. 1099" (Marcel), the Crusaders entered Palestine, and obtained possession of Jerusalem; where they established themselves.

In "A. D. 1101," the accession of El-Amr, of the Fatimite Dynasty, the seventh sultan of Egypt, took place. A coin issued by him at Alexandria, is figured by Marcel, p. 126.

According to Klaproth, the mariner's compass was brought by the Arabs from China, "about A. D. 1117."

* According. to Pereira, the fox-glove (Digitalis purpurea) is mentioned in a Saxon Glossary of Alfric, and in a Greek Translation of Apuleius.-This species of Digitalis was not seen by Sibthorp in Greece; and I have met with no evidence that it is known in Egypt. 
About "A. D. 1124" (Marcel), the fanatical sect of the Bathenians or Hassassins was formed: their leader, Ismael, established himself in the new Christian kingdom, in the mountains near Damascus, and rendered himself formidable to all around, by means of his secret emissaries.

In “A. D. 1130" El-Amr was assassinated by emissaries of Ismael. He was succeeded by El-Hafez, of the Fatimite Dynasty, the eighth sultan of Egypt. A coin issued at Alexandria during the reign of ElHafez, is figured by Marcel, p. 127.

The "zubbad" of Edrisi and Ibn Baitar, is admitted to be civet; a perfume obtained from a weasel-like animal (Viverra zibetha).-The "galia muscata" (from the Greek $\gamma \alpha \lambda \varepsilon \alpha$ ) of Nicolaus Præpositus and Franciscus Pedemontium, may also be compared. Cadamosto met with civet on the Gambia; Alpinus iii. 15, mentions its medicinal use in Egypt; and I found it a well-known article of commerce at Mocha. According to Browne, the civet animal is kept in cages in Darfour, and occurs wild further South.

In "A. D. 1149-50," the accession of Dhafer, of the Fatimite Dynasty, the ninth sultan of Egypt, took place. A coin issued at Alexandria during his reign, is figured by Marcel, p. 128.

About this time, the manufacture of ardent spirits, or alcoholic distillation, is said to have been first practised in Europe.

In "A. D. 1155," the accession of Fayez, of the Fatimite Dynasty, the tenth sultan of Egypt, took place.

The anacardi of Nicolaus Præpositus, and Christophorus de Honestis, may be compared with the seeds of Cardiospermum helicacabum. -This plant is noticed by Valerius Cordus, Tragus, Fuchsius, and Matthioli; was seen by Delile in gardens at Cairo; and according to Cailliaud, has a native name in Dongola.

In "A. D. 1160," the accession of Adhed, of the Fatimite Dynasty, the eleventh sultan of Egypt, took place.

In "A. D. 1168" (Munk and Marcel), an army of Crusaders from Palestine, employed in Egypt to repel a Syrian invasion, captured Bilbeis or Bubastis, and advanced as far as Cairo; but were finally compelled to retire.

On the death of Adhed, "A. D. 1171," the Fatimite Dynasty became extinct: the succeeding Egyptian sultans made no claim to spiritual authority, but acknowledged that of the Abbassid khalifs. 
Saladdin was at the time the real ruler of Egypt; though acting, to some extent, under the orders of Nooreddin of Damascus.

On the death of Nooreddin, "A. D. 1173," Saladdin became the acknowledged sultan both of Egypt and Syria. He coined gold and silver, to redeem the glass money then in circulation (Marcel, pp. 139 and 144). He surrounded Cairo with a wall of stone; built the citadel; and within it, cleared the ancient well, now called Joseph's well (Wilkinson, Thebes and Egypt, p. 305). To his reign also is attributed, the removal of the outer coating of the Great Pyramid (Marcel, p. 141).

The venich of Hildegard, is referred by Sprengel to the Digitaria sanguinale.-This grass, according to Beckmann, was once regularly cultivated in Europe. It is figured by Lobel and by Camerarius; was seen by Sibthorp in the Grecian Archipelago; and by Hasselquist, Forskal, and Delile, growing spontaneously in Egypt. The D. filiformis was also seen by Delile, growing spontaneously at Rosetta.

The bunesdarm of Hildegard ii. 173, is referred by Fuchsius and Sprengel to the chickweed (Stellaria media).-This plant was seen by Sibthorp in Greece; and by Hasselquist, Forskal, and Delile, growing as a weed in Egypt.

The razela of Hildegard ii. 174, is referred by Sprengel to the Polygonum persicaria.-This plant is noticed by Ruellius, Fuchsius, Dodonæus, Lobel, and Gerarde : and was seen by Sibthorp in Crete; and by Forskal and Delile, growing as a weed at Alexandria and Rosetta. The P. salicifolium was also seen by Delile, growing spontaneously at Rosetta.

In “A. D. 1187" (Munk and Marcel), the Crusaders were driven out of Jerusalem and Palestine; with the exception of a few fortified posts on the coast, which remained in their possession for many years.

In "A. D. 1193," the accession of Melek-Aziz Othman, the second Ayoubite sultan of Egypt, took place. A copper coin issued by him, is figured by Marcel, p. 146.

In "A. D. 1198," the accession of Melek-el-Mansur, the third Ayoubite sultan of Egypt, took place. A copper coin issued by him, is figured by Marcel, p. 147.

In "A. D. 1200," the accession of Melek-Adel Seif-Eddin, the fourth Ayoubite sultan of Egypt, took place. Silver and copper coins issued by him, are figured by Marcel, p. 149.

The "sisaban" of Madschhul and Ibn Baitar, according to Egyptian usage, is the Eschynomene sesban: a plant clearly derived from some 
Tropical country.-The $\mathrm{E}$. sesban was seen under cultivation by Alpinus, Forskal, and Delile; and I found it common in the gardens of Lower Egypt.

In "A. D. 1218" (Munk), the accession of Melek-Kamel, the fifth Ayoubite sultan of Egypt, took place. A gold coin issued at Cairo during his reign, is figured by Marcel, p. 151.

The Sixth Crusade was directed against Egypt: and in "A. D. 1219" (Munk and Marcel), the Crusaders arriving by sea, captured Damietta. Two years later, they advanced as far as the head of the Delta ; but were finally obliged to capitulate, and leave the country.

The Arab settlers in Spain and Portugal appear to have been acquainted with benzoin; as it is enumerated by Jao de Sousa among the ingredients of the "bachur" ointment.-Amatus Lusitanus speaks of benzoin: Bontius states, that the best is obtained from an arborescent vine growing in Java; and Forskal (Mat. Med.) mentions the importation into Egypt of gum " benzoæ" from India.

In "A. D. 1227" (Desvergers), the death of Djenghiz-Khan took place. The wars of this Tartar chief and his immediate successors, though directed in part against the Arabs, contributed to the extension of Muslim power in the East, especially in Central Asia and towards the borders of China.

According to F. Adams, grains of paradise (Amomum grana-paradisi), are mentioned by Ibn Baitar.-Franciscus Pedemontium also speaks of "grana paradisi." This spice is a production of Equatorial Africa; and according to Delile, is sold in the drug shops of Cairo.

The "luffah" of Ibn Baitar, according to Egyptian usage, is the Luffa. The reтparyoupov of the Greek version of Rhazes, may also be compared.-The Luffa is a Cucurbitaceous plant, figured by Vesling, and according to Forskal, Delile, and Clot-Bey, cultivated in Egypt for ornament, and for the sponge-like tissue obtained from the fruit.

The "najm" of Ibn Baitar, according to Forskal's account of the Egyptian usage, is the Agrostis alba. This grass was seen by Sibthorp in Greece; and by Forskal and Delile, growing spontaneously at Rosetta and Cairo.

The "khafur" of Ibn Baitar, according to Forskal's account of the Egyptian usage, is a species of wild oat, Avena fatua.-This grass was seen by Sibthorp in Greece; and by Forskal and Delile, growing spontaneously at Cairo. The A. sterilis was also seen by Sibthorp in Greece; and by Delile, growing spontaneously at Cairo. 
The "tumluk" of Ibn Baitar, may be compared with "tamalak," the Dongola name (according to Cailliaud) of Cleome pentaphylla.-This plant is cultivated as an esculent in Dongola; and according to Alpinus, Delile, and Clot-Bey, is used in Egypt for feeding cattle. It grows as a weed in Hindostan and the East India Islands, as appears from Rheede, Rumphius, and Graham.**

In "A. D. 1238," the accession of Melek-Adel II., the sixth Ayoubite sultan of Egypt, took place.

In "A. D. 1240," the accession of Melek-Saleh, the seventh Ayoubite sultan of Egypt, took place. His name has been found in an inscription over the door of his tomb at Cairo (Wilkinson, Thebes and Egypt, pp. 297 and 551).

The sultan of Damascus having made a treaty with the Crusaders, by which the latter were again admitted into Jerusalem, Melek-Saleh invited the Kharesmians, who had already entered Syria. In "A. D. 1244" (Munk), the Kharesmians invaded Palestine and captured Jerusalem: three years afterwards, they were expelled by the combined forces of the Syrians and Egyptians.

Melek-Saleh increased the number of Memluks beyond precedent; by the purchase of some thousands of young Turks, to whom he gave a military education, and thus obtained a formidable body of soldiers exclusively devoted to his interests.

The Seventh Crusade was directed against Egypt: the Crusaders landed and captured Damietta, in "A. D. 1247" (Marcel); three years afterwards, they advanced to the head of the Delta, but were again obliged to capitulate and leave the country.

Immediately after the defeat of the Crusaders, "April, A. D. 1250" (Marcel), the death of Melek-Saleh (kept secret for several months) was declared; and his son, Turan Schah, was acknowledged as the eighth Ayoubite sultan of Egypt.

Two months afterwards, the Memluks, or military slaves, perceiving that they held in their hands the power of their master, put him to death; one of their own number was declared sultan, and the Institution was rendered permanent, by means of fresh purchases from abroad (Clot-Bey and Marcel). Ibek thus became the head of the

* According to Sprengel, the skirret (Sium sisarum), was brought from Northern China into Europe during the Thirteenth Century.-The plant is now abundantly cultivated in Europe; but appears to hare remained unknown in Egypt. 
Bahrite Dynasty, and the first Memluk sultan of Egypt. A copper coin issued during his reign, is figured by Marcel, p. 158.

In "A. D. 1257," the accession of Nooreddin Ali, the second Memluk sultan of Egypt, took place.

In " A. D. 1258" (Desvergers and Marcel), the Tartars under Hulagu-Khan captured Bagdad, and the hereditary spiritual khalifate was abolished. Three years later (Marcel), some members of the Abbassid family took refuge in Egypt; where one of them was proclaimed khalif; and where the highest religious office of the Muslims was continued.

In " A. D. 1259," the accession of Kotoz, the third Memluk sultan of Egypt, took place. In the course of the year, he defeated the Tartar army of Hulagu-Khan in Palestine (Marcel, p. 162).

In "A. D. 1260" the accession of Beybars, the fourth Memluk sultan of Egypt, took place. He exterminated the remnant of the fanatical sect of the Bathenians or Hassassins (Marcel); constructed at Cairo the mosque which bears his name; also, various works of public utility both here and at Alexandria, Damietta, and Rosetta. His coins and constructions are remarkable for the presence of the figure of the lion; contrary to the precepts of the Muslim religion.

The "ukhowan" of the Thousand and One Nights, may be compared with the "achaouan" of Alpinus (Pl. 39); which seems to be the Pyrethrum parthenium. - This plant was seen by Sibthorp in Greece; and Forskal enumerates it, doubtfully, among the plants of the mountain region of Yemen.

There is however another "achaouan" used medicinally in Egypt, the Cineraria maritima (Alpinus Pl. 26). - I found this plant frequent in the environs of Cairo; but apparently indigenous. Sibthorp met with it in Rhodes.

In "A. D. 1277," the accession of Barakah-Khan, the fifth Memluk sultan of Egypt, took place.*

The composition of gunpowder, long known in China, may have been brought from that country by Marco Polo; but its application in warfare in casting projectiles, appears to have been chiefly practised in Europe. Gunpowder is mentioned by Roger Bacon in a tract published in "A. D. 1278."

* The xapdroßoravor of Nicolaus Myrepsus iii. 60, may be compared with the Leonurus cardiaca.-This plant is figured by Brunfels and by Fuchsius, 395 ; was seen in Greece by Sibthorp and Bory de St. Vincent, but appears to have remained unknown in Egypt. 
In “A. D. 1279," the accession of Salamesch, the sixth Memluk sultan of Egypt, took place. His reign lasted a few months only.

In "the same year," the accession of Kalaoon, the seventh Memluk sultan of Egypt, took place. He built the mosque which bears his name; and commenced the celebrated moristan or hospital at Cairo. During his reign, a great impulse was given to the erection of buildings of every description in Cairo (Clot-Bey xv. 30). A coin issued by him at Aleppo, is figured by Marcel, p. 168.

The bernice arbor of Vincentius Bellovacensis, is referred by Sprengel to Terminalia? vernix; the varnish tree of China and the Molucca Islands.-This tree is figured by Rumphius, Pl. 86 .

In "A. D. 1290" the accession of Khalyl, the eighth Memluk sultan of Egypt, took place.

The flos siriacus i flos malve of Symon Januensis (Sinonim.), may be compared with the Hibiscus Syriacus. - This plant is noticed by Camerarius and Gerarde ; and according to Forskal, Delile, and Clot-Bey, is common in the gardens of Egypt.

In “A. D. 1293," Beydarah became sultan of Egypt for a single day. He was succeeded by Naser: who built at Cairo the mosque which bears his name; also, various bridges, fountains, academies, and other works of public utility. A copper coin issued by Sultan Naser, is figured by Marcel, p. 172.

The virga varea of Arnaldus, is referred by Dalechamp and others to the Solidago virgaurea.-This plant was seen by Sibthorp in Greece; and by Hasselquist, at Damietta.

About “ A. D. 1297" (Alsted), Osman or Othman, having defeated the Greek armies in Asia Minor, laid the foundation of the Turkish Empire : a new phase of the progress of the Muslims.

In "A. D. 1341," the accession of Abubekr, the eleventh Memluk sultan of Egypt, took place. After a reign of "forty days," he was succeeded by Koutchouk.

In "A. D. 1342," the accession of Schahabeddin, the thirteenth Memluk sultan of Egypt, took place. In the same year, he was succeeded by Emadeddin.

In " A. D. 1344," the accession of Schaban-Kamel, the fifteenth Memluk sultan of Egypt, took place.

In "A. D. 1346," the accession of Zeyneddin, the sixteenth Memluk sultan of Egypt, took place.

In “A. D. 1347," the accession of Hassan, the seventeenth Memluk 
sultan of Egypt, took place. He built at Cairo the great mosque which bears his name. A gold coin issued by him, is figured by Marcel, p. 174.

The $\pi \varepsilon p \pi \pi \lambda_{0 \times} \times \delta_{\alpha} \alpha$ of the Scholiast of Theocritus v. 128, according to Forskal's and Sibthorp's account of the Greek usage, is the Convolvulus arvensis. - This plant is figured by Plukenet and Boccone; was seen in Egypt by Forskal and Delile; and I met with it, growing as a weed in the Dekkan.

In "A. D. 1361," the accession of Mohammed El-Mansur, the eighteenth Memluk sultan of Egypt, took place. A gold coin issued at Cairo during his reign, is figured by Marcel, p. 174.

In "A. D. 1363," the accession of Schaban-Aschraf, the nineteenth Memluk sultan of Egypt, took place. A coin issued by him, is figured by Marcel, p. 175.

In “A. D. 1377," the accession of Ali El-Mansur, the twentieth Memluk sultan of Egypt, took place.

In "A. D. 1381," the accession of Hadgi Saleh, the twenty-first Memluk sultan of Egypt, took place. In the following year, he was deposed; but some years later, he was recalled to the throne, and was shortly afterwards put to death. In him, the Bahrite Dynasty became extinct.

In "A. D. 1382," the accession of Barkook, the head of the Borgite Dynasty and the twenty-second Memluk sultan of Egypt, took place. He built at Cairo the mosque which bears his name; also, a college; and he introduced some changes in the administration of the government. The buildings so conspicuous in the Desert, to the eastward of Cairo, are the tombs of the Borgite Memluk kings (Wilkinson, Thebes and Egypt, p. 307).

In " A. D. 1399," the accession of Faradj, the twenty-third Memluk sultan of Egypt, took place.

In the same year (Desvergers and Marcel), the Tartars under Timur or Tamerlane, threatened Egypt; overran Syria and Asia Minor, and defeated the Turks; and thus indirectly, saved for a time the Greek or Byzantine Empire.

In "A. D. 1412," Shekh Mahmoudi, partly through the interference of Mostain, the spiritual khalif, became the twenty-fourth Memluk sultan of Egypt. He built one of the most remarkable mosques at Cairo: and according to Wilkinson, coined the moaiudee as a substitute for the para (Thebes and Egypt, p. 555). 
In "A. D. 1421," the accession of Ahmed El-Mozzaffer, the twentyfifth Memluk sultan of Egypt, took place. After some months, he was succeeded by Seifeddin Tattar; and before the close of the year, by Mohammed Saleh.

In "A. D. 1422," the accession of Barsebay El-Aschraf, the twentyeighth Memluk sultan of Egypt, took place. He built at Cairo the mosque which bears his name; and carried on war in the Mediterranean against the Europeans or Franks.

The dianthi of Manfredus de Monte Imperiali, according to Sprengel, is clearly the carnation (Dianthus caryophyllus).-This plant is noticed by Ruellius; was seen in Egypt by Forskal and Delile; and I found it everywhere a favourite among the Arabs, and frequently kept by them in pots.

The art of printing, though long practised in China, was independently invented in Europe, "about A. D. 1430," by Laurentius. The improvement of movable types, was made twelve years later (Edin. Cycl.)

In "A. D. 1438," the accession of Djemaleddin Yusuf, the twentyninth Memluk sultan of Egypt, took place. In the same year, he was succeeded by Djakmak.

The coffee plant (Coffea arabica), a native of the region southwest of Abyssinia, is said to have been introduced into Yemen about A. D. 1450 ; though according to Lane, the berries were first imported into Egypt fifty years later.-Rauwolf is said to be the earliest European traveller who speaks of coffee. The living plant was seen in Egypt by Alpinus; and, as appears from Clot-Bey and Figari, has been recently re-introduced.

In "A. D. 1453," the accession of Othman El-Mansur, the thirtyfirst Memluk sultan of Egypt, took place. In the same year, he was succeeded by Ynal.

In this year also, the Turks obtained possession of Constantinople, and the Greek or Byzantine Empire became extinct.

Seeds of the Abrus precatorius, were seen by Cadamosto, A. D. 1454, at the River Senegal.-The living plant, as appears from Alpinus and Hasselquist, has been sometimes cultivated in Egypt.

According to Sprengel, Cadamosto met with the baobab (Adansonia 
digitata) at the River Senegal.- The fruit (brought down the Nile) is figured by Alpinus; and according to Forskal and Delile, is sold in the drug shops of Cairo.

In " A. D. 1461," the accession of Achmed Abu-l-Fetah, the thirtythird Memluk sultan of Egypt, took place. His name occurs on a coin figured by Marcel, p. 185.

In the same year, the accession of Koschkadam, the thirty-fourth Memluk sultan of Egypt, took place. He was by birth a Greek.

In "A. D. 1467," the accession of Belbay, the thirty-fifth Memluk sultan of Egypt, took place. In the same year, he was succeeded by Timar Bogha.

In "A. D. 1468," the accession of Kayt-Bay, the thirty-seventh Memluk sultan of Egypt, took place. He built at Cairo the small but remarkable mosque which bears his name (Clot-Bey, xv. 2).

According to Sprengel, The Verbena officinalis is figured in the Hortus Sanitatis of Jo. Van Cube, and by Brunfels.-The plant is also noticed by Belon, Matthioli, and Lobel; was seen in Greece by Sibthorp; and I found it common in waste ground in Lower Egypt. The $V$. supina is noticed by Dodonæus and Lobel; and was seen by Sibthorp in Asia Minor, and by Forskal and Delile at Cairo. The aspect of these plants does not well accord with the Mediterranean vegetation.

The "rosam moscheuton" of Hermolaus Barbarus, may be compared with the Hibiscus abelmoschus.-This plant was seen by Alpinus and Delile in gardens at Cairo.*

The Cassia sophera was probably known in Egypt during the Early Muslim Period.- The plant was seen by Alpinus, Forskal, and Delile, in gardens at Cairo ; by Browne, in Darfour; and by Graham, in Hindostan.

The Kalanchoe Egyptiaca was probably known in Egypt during the Early Muslim Period.-It is enumerated by Forskal, Delile and

* The "cotula" of Hermolaus Barbarus and Matthioli, may be compared with the Anthemis cotula.-This plant, according to Sprengel, is noticed by Brunfels and Fuchsius: it was seen in Greece by Bory de St. Vincent, but appears to have remained unknown in Egypt.

The Chenopodium bonus Henricus is said to have been cultivated in Europe during the Early Muslim Period.-The plant was seen by Sibthorp in Greece; but appears to have remained unknown in Egypt. 
others, among the garden plants of Egypt; and was besides seen by Forskal on the mountains of Yemen.

The Cissus rotundifolia was probably known in Egypt during the Early Muslim Period.-The plant was seen by Delile in gardens at Cairo; and by Forskal, on the mountains of Yemen.

The Euphorbia thymifolia, an Indian weed, was probably known in Egypt during the Early Muslim Period.-It is figured by Plukenet; and was seen by Forskal in the mountain region of Yemen; and by Delile, in Upper Egypt and at Damietta.

The Hibiscus trionum, a Tropical weed, was probably known in Egypt during the Early Muslim Period.-The plant is figured by Matthioli, Lobel, and Parkinson; and was seen by Sibthorp in Greece and Cyprus; and by Forskal and Delile in Egypt.

The Sida spinosa, another Tropical weed, was probably known in Egypt during the Early Muslim Period.-It was seen by Forskal and Delile, growing spontaneously around Cairo.

The Sida mutica, also a Tropical weed, was probably known in Egypt during the Early Muslim Period.-It was seen by Delile, in gardens at Rosetta; and again, in Nubia, where it has a native name.

The Achyranthes argentea, another Tropical weed, was probably known in Egypt during the Early Muslim Period.-It was seen by Hasselquist in Palestine; by Sibthorp in Sicily; and by Forskal, Delile, and others, growing spontaneously around Cairo.

Other Tropical weeds now common in Egypt, were probably introduced during or before the Early Muslim Period: as, the Aerva tomentosa, seen by Forskal and Delile, in Yemen, in Upper Egypt, and in gardens at Cairo; the Celosia margaritacea, seen by Delile at Cairo; and the Alternanthera sessitis, seen by Hasselquist at Jerusalem, and by Forskal and Delile at Rosetta.

Seeds of an undetermined species of Chamariphis, were found by Delile in the drug shops of Cairo: the same description of seeds may have been imported during the Early Muslim Period.

The Impatiens balsamina was probably known in Egypt during the Early Muslim Period.-The plant is figured by Fuchsius and by Matthioli; is enumerated by Clot-Bey and Figari, as cultivated in the gardens of Egypt; and according to Graham, grows wild in the environs of Bombay.

The Dactyloctenium, an Indian grass, was probably known in Egypt during the Early Muslim Period.-It was seen in Egypt, by Alpinus, Forskal, and Delile; and in Greece, by Sibthorp. 
The Echinochloa crus-galli was probably known in Egypt during the Early Muslim Period.-This grass is figured by Matthioli; and was seen by Sibthorp in Greece ; and by Forskal and Delile in Egypt.

The Setaria verticillata was probably known in Egypt during the Early Muslim Period.-This grass was seen in Egypt by Delile; by Sibthorp in the Grecian Archipelago; and by Roxburgh and Graham in Hindostan.

The Setaria glauca was probably known in Egypt during the Early Muslim Period.-This grass was seen by Forskal and Delile, growing spontaneously at Cairo and Rosetta; by Sibthorp, in Greece; and by Roxburgh and Graham, in Hindostan. The S. viridis was seen by Sibthorp at Constantinople; and is enumerated by Delile among the weeds of Egypt.*

The Ornithogalum elatum was perhaps cultivated in Egypt during the Early Muslim Period. The living plant was received by Andrews from Alexandria.

The Solanum pseudocapsicum was probably known in Egypt during the Early Muslim Period.-The plant is noticed by Gesner, Dodonæus, and Bauhin; and was seen by Forskal and Delile in gardens at Cairo.

The Convolvulus Cairicus was probably known in Egypt during the Early Muslim Period.-The plant is noticed by C. Bauhin (Pin. 295), and by Vesling, and was seen by Forskal and Delile in gardens at Cairo. Delile also met with it, growing along the banks of the Nile.

The Lavatera arborea was probably known in Egypt during the Early Muslim Period.-This plant was seen by Sibthorp on the seacoast near Athens; and by Delile, in gardens at Alexandria. The $L$. Cretica was seen by Sibthorp in Crete and in other parts of Greece; and by Delile, at Damietta.

The Antirrhinum linaria was probably known in Egypt during the Early Muslim Period. - It has a native Egyptian name; as appears from Forskal, who met with the plant in a single garden at Cairo.

Seeds of the Datisca cannabina were probably imported into Egypt during the Early Muslim Period.-This is an indigenous plant of Crete and Asia Minor: seeds were seen by Forskal and Delile in the drug shops at Cairo.

* The Lappago racemosa was probably known in Europe during the Early Muslim Period.-This grass is noticed by Tragus, Tournefort, and Haller; was seen by Sibthorp in Greece; and by Graham and others, in Hindostan; but appears to have remained unknown in Egypt. 
Of the eighteen following grasses and herbaceous plants, some may have been growing in Egypt from the time of the first introduction of Agriculture; but being inconspicuous, were overlooked by the Ancient writers; or if noticed by them, have not as yet been identified: as the Bromus mollis:-Seen by Sibthorp in the Grecian Archipelago; and by Delile, growing spontaneously at Cairo.

The Bromus rubens and B. distachyos:-Seen by Sibthorp in Greece; and by Forskal and Delile, growing spontaneously at Alexandria.

The Festuca uniglumis:-Seen by Sibthorp in Greece; and by Forskal and Delile, growing spontaneously at Alexandria and Rosetta.

The Crypsis aculeata:-Figured by Matthioli; and seen by Sibthorp in Greece; and by Forskal and Delile, growing spontaneously at Alexandria and Cairo. The C. schoenoides, by some writers considered as only a variety, was also seen by Delile growing spontaneously at Cairo.

The Crypsis alopecuroides:-Seen by Delile growing spontaneously at Cairo.

The Poa annua:-Seen by Sibthorp in Greece; and by Hasselquist, at Damietta.

The Poa eragrostis:-Figured by Lobel and by Barrelier; and seen by Sibthorp in Greece; by Forskal and Delile, growing spontaneously at Cairo; and again by Delile in Nubia (where it has a native name); and by Forskal in the mountain region of Yemen.

The Dactylis glomerata:-Noticed by Dalechamp and C. Bauhin; and seen by Sibthorp in the Grecian Archipelago; and by Delile, growing spontaneously at Alexandria.

The Vella annua:-Seen by Clusius in Spain; by Sibthorp in Greece; and by Delile growing spontaneously at Alexandria.

The Coronopus Ruellii:-Noticed by Ruellius and Camerarius; and seen by Sibthorp in Greece; and by Forskal and Delile, growing spontaneously at Cairo.

The Arenaria rubra:-Seen by Sibthorp in Greece and Cyprus; and by Delile, growing spontaneously at Alexandria, Rosetta and Cairo.

The Arenaria media:-Seen by Sibthorp in Greece; and (according to Delile) "by Granger in Egypt, and by Olivier at Alexandria." This, however, is a maritime plant, and probably indigenous.

The Polycarpon tetraphyllum:-Seen by Sibthorp along waysides in the Grecian Archipelago; and by Delile, growing spontaneously at Alexandria. 
The Trifolium procumbens:-Seen by Sibthorp in Greece and $\mathrm{Cy}$ prus; and by Hasselquist at Damietta.

The Galega officinalis:-Noticed by Hieronymus Fracastor, Gesner, Dodonæus, and Gerarde; and seen by Sibthorp on the mountains of Northern Greece; but according to Clot-Bey and Figari, only recently introduced into Egypt.

The Mentha rotundifolia:-Noticed by C. Bauhin and Tournefort; and seen by Sibthorp in Crete and other parts of Greece; but according to Clot-Bey and Figari, only recently introduced into Egypt.

And the Lamium amplexicaule:-Seen by Sibthorp in Greece; and by Delile in cultivated ground at Damietta.*

During the reign of Sultan Kayt-Bay, Europe, having become the home of many enlightened nations, was in the midst of the Revival of Literature; a result, to which the invention of printing largely contributed.

\section{THE MODERN MUSLIM PERIOD.}

In A. D. 1492, Columbus sailed on his First Voyage; and Egypt ceased to be the main or only channel through which foreign animals and plants were transmitted to Europe. The broad ocean now became the theatre of commerce; and the old routes were comparatively neglected. In the midst of the new order of things in the surrounding countries, Egypt appears to have remained in a measure a neutral point; slowly reached, and but slightly influenced.

According to Gomara xvi. and xvii., Columbus procured from the aboriginals of the West Indies "batatas que son rayzes dulces," or sweet-potatoes (Convolvulus batatas).-This plant is noticed by Mo-

* The European gooseberry (Ribes grossularia) was probably cultivated in Europe during the Early Muslim Period.-The plant was seen by Sibthorp and Bory de St. Vincent, wild on the high mountains of Crete, and of the Peloponnesus ; but it appears to have remained unknown in Egypt.

The horse-radish (Cochlearia armoracia) was probably cultivated in Europe during the Early Muslim Period.-The plant is noticed by Petrus Placentius, Fuchsius 660, Matthioli, Gerarde, and T. Johnson; was seen by Belon at Constantinople; but appears to have remained unknown in Syria and Egypt.

The cockscomb (Celosia cristata) was probably known in Europe during the Early Muslim Period.-The plant is noticed by Lobel, Bauhin, and Rumphius; has a native name in the gardens of India ; was seen by Forskal, both in Yemen and at Constantinople; and in all probability, has been sometimes planted in Egypt. 
nardes and Lobel; is figured by Rheede and Rumphius, as cultivated in Hindostan and Amboyna; was seen by Hasselquist in Palestine; and according to Clot-Bey and Figari, has been recently introduced into Egypt.

According to Gomara, Columbus procured from the aboriginals of the West Indies "axies, especia que les quemo la lengua," or capsicum (the fruit of Capsicum annuum).-This plant is noticed by Tragus, Cordus, Fuchsius, Matthioli and Lobel; is figured by Rheede, as cultivated in Hindostan; and was seen by Hasselquist at Jerusalem. The C. frutescens (regarded by Graham as only a variety) was seen in Egypt by Forskal and Delile, and again by Forskal in Yemen.

According to Gomara, Columbus procured from the aboriginals of the West Indies "gallipauos que son mejores que pauos y gallinas," or the domestic turkey (Meleagris gallipavo).-Oviedo distinctly describes the turkey; but many years appear to have elapsed, before the bird became generally known in Europe. Its introduction into Egypt was subsequent to the visit of Alpinus : but it is now common there, and is sometimes called the "Maltese fowl," a name indicating the route of transmission.

According to Gomara, Columbus found "maiz," or maize (Zea mays), cultivated by the aboriginals of the West Indies.-Its introduction into Europe appears to have taken place shortly afterwards; for Rhamnusis states, that the plant "was first seen in Italy in his own time." Forskal found the maize cultivated among the mountains of Yemen, and also in Egypt; and Delile's account of the Egyptian name and tradition indicates, that the plant was received from the North by the way of Syria and Turkey.

The "axes or ajes," found by Columbus (Navig. Ixxxix.) cultivated by the aboriginals of the West Indies, is referred by Humboldt and others to the yam (Dioscorea).-From a figure given by Alpinus, the yam appears to have been sometimes planted in Egypt.

According to Barcia, Columbus on his Second Voyage, met with pineapples (Bromelia ananas).-This plant is noticed by Monardes iii. 4; and is figured by Rheede and Rumphius, as cultivated in Hindostan and Amboyna. Hasselquist speaks of the pineapple having been formerly planted at Damietta; and Clot-Bey and Figari mention some recent unsuccessful attempts to re-introduce this fruit into Egypt.

In "A. D. 1496," the accession of Mohammed Abu-l-Saadat, the thirty-eighth Memluk sultar of Egypt, took place. 
In "A. D. 1498," the accession of Kansu Abu-Said, the thirty-ninth Memluk sultan of Egypt, took place.

In " A. D. 1499" (Marcel), the accession of Kansu Djan-balat, the fortieth Memluk sultan of Egypt, took place.

In "A. D. 1500" (Marcel), the accession of Toman-Bay, the fortyfirst Memluk sultan of Egypt, took place.

In " A. D. 1501," the accession of Kansu El-Gouri, the forty-second Memluk sultan of Egypt, took place. He built at Cairo the mosque which bears his name (Wilkinson, Thebes and Egypt, p. 297); and sent a fleet down the Red Sea against the Portuguese, who had entered the Indian Ocean.

According to Wilkinson (Thebes and Egypt, p. 546), the use of Kufic letters ceased in A. D. 1508.

In the same year, according to Pereira, guaiacum (the product of Guaiacum officinale) was first brought to Europe by Gonsalvo Ferrand; who obtained the drug from the natives of St. Domingo.-Guaiacum is noticed by Dalechamp (Annot. in Diosc.), and by Monardes; and Forskal (Mat. Med.) speaks of its medicinal use in Egypt.

In "A. D. 1516," the accession of Toman-Bay II., the last of the Borgite Memluk Dynasty, and the last sultan of Egypt, took place.

The Turks having defeated the Egyptian army in Syria, partly through the employment of artillery (Marcel, p. 189), the Turkish sultan, Selim, entered Egypt in "A. D. 1517," and obtained possession of the country. The sovereignty and Muslim spiritual authority were now transferred to Constantinople; the Memluks were formed into an aristocracy; and from this time, the names of the Turkish sultans were inserted on the Egyptian coins (Wilkinson, Thebes and Egypt, p. 557$) *$

In "A. D. 1520," the accession of Suliman II., the second Turkish sultan who ruled Egypt, took place. The coins issued by him bear the date of his accession only, agreeably to the uniform practice of the Turkish sultans (Marcel, p. 200).

Whether the celery (Apium dulce) is a European or Magellanic plant, is a question to be decided by comparing specimens. The Straits of Magellan were first visited by Europeans in the last-named year.Twenty-six years later, Belon found the "ache" cultivated and blanched

* According to Pereira, the Spaniards first became acquainted with cochineal (Coccus cacti) on their arrival in Mexico, about A. D. 1518.-Cochineal has doubtless been sometimes imported into Egypt; but I have met with no direct evidence of the fact. 
at Constantinople: the plant referred to, is clearly the celery; as is the "apium called carass," enumerated by Alpinus among the esculent plants of Egypt. According to Clot-Bey and Figari, the cultivation of celery in Egypt is nearly confined to the Pasha's gardens.*

According to Piso (pp. 96 and 159), The Carica papaya is mentioned by Ximenes, as cultivated by the aboriginals of Mexico.-The plant, according to Clot-Bey and Figari, has recently been successfully introduced into Egypt.

According to Clusius and Sprengel, The guava (Psidium) is mentioned by Oviedo (about A. D. 1525).-The plant is noticed by Monardes iii. 5, as brought from "Tierra Firme;" is figured by Rheede and Rumphius, as cultivated in Hindostan and Amboyna; and according to Clot-Bey and Figari, has recently been successfully introduced into Egypt. $†$

According to Sprengel, The Saponaria officinalis is noticed by Ruellius, A. D. 1529, and by Fuchsius.-The plant is figured by Lobel; was seen in Greece by Sibthorp; but according to Clot-Bey and Figari, has only recently been introduced into Egypt.

According to Pereira, Sarsaparilla (the root of certain species of Smilax) first became known in Europe in A. D. 1530.-Alpinus ascertained, that a portion of the sarsaparilla of commerce is really derived from the Mediterranean; and both he and Forskal (Mat. Med.) speak of the medicinal use in Egypt.

* According to Beckmann, buckwheat (Polygonum fagopyrum) is mentioned in a German Bible, printed in A. D. 1522; or about the time when, according to John Bruyerinus (who wrote eight years afterwards), the plant was brought from Northern Asia into Europe: the same account of its origin and introduction, is given by Ruellius and Conrade Heresbach.-The plant was received by Sibthorp from Constantinople; but appears to have remained unknown in Egypt.

$\dagger$ The "bixa" of Oviedo, is referred by Clusius and others to the arnotto tree (Bixa Orellana).-Arnotto has doubtless been sometimes imported into Egypt; but I have met with no direct evidence of the fact.

According to Sprengel, The lily of the valley (Convallaria majalis) is deseribed by Johannes Manardus, and by Brunfels i. 211.-The plant is noticed by Fuchsius, Dodonæus, and Lobel ; was seen in Greece by Sibthorp; but appears to have remained unknown in Egypt.

The Viburnum opulus is noticed by Ruellius, Cordus, Tragus, Gesner, Matthioli, Dodonæus, Thalius, and Tabernæmontanus; and the cultivated variety, called the snowball tree, is figured by C. Bauhin.-The plant was seen by Forskal and Sibthorp at Constantinople; but appears to have remained unknown in Greece and Egypt.

¥ According to Sprengel, the Viola tricolor, or heart's ease, is figured by Brunfels, A. D. 1532.-The plant is also figured by Fuchsius 803, Dodonæus, Lobel, and Stapel, p. 
The introduction of the Cactus opuntia into the Mediterranean countries, appears to have taken place as early as the last-named date; for Matthioli states, That the plant was brought within his recollection from the West Indies.-This species of Cactus has become abundantly naturalized around the Mediterranean; and was seen in Egypt by Forskal and Delile.

According to Clusius and Barcia, the "papas" of Peru, or potato (Solanum tuberosum), is described by Çarate, Petrus Cieca 40, and Gomara.-The plant is figured by Lobel (Nova Stirp. adv. p. 317), C. Bauhin, and Gerarde; but according to Clot-Bey and Figari, has only recently been introduced into Egypt.

The Melilotus coerulea is noticed by Fuchsius, A. D. 1542, and by Cordus, Gesner, Turner, Anguillara, Matthioli, Dodonæus, and C. Bauhin.-The plant, according to Clot-Bey and Figari, has only recently been introduced into Egypt.

In the last-named year, De Soto found the kidney-bean (Phaseolus vulgaris) cultivated by the aboriginals of Florida.-In England, the plant is often called the "French bean;" a name that indicates a Canadian route of introduction. Forskal appears to be the only writer, who has met with the plant ("lubia Frandji") in Egypt.

The "tanacetum Peruvianum" of Valerius Cordus, is referred by Beckmann to the Tagetes erecta. - This plant is figured by Tragus, Fuchsius, Matthioli, and Dodonæus; and was seen by Forskal and Delile in gardens at Cairo.*

According to Garcilasso de la Vega (384), The black rat (Mus rattus) was introduced into South America by European ships, in A. D.

651 ; and was seen by Graham in gardens at Bombay; I have met with no evidence that it is known in Egypt.

* The "grase poley" of Cordus, is referred by C. Bauhin and Willdenow to the Lythrum hyssopifolium.-This plant is noticed also by Gesner, Camerarius, Barrelier, Tournefort, and Ruppius; and was seen in Greece by Sibthorp; but appears to have remained unknown in Egypt.

The "ribes hortense" of Tragus, Clusius, and Besler, is referred by Willdenow and others to the red currant of the gardens (Ribes rubrum).-This plant, as suggested by Dr. T. W. Harris, may have been derived from the mountains of Canada and Maine. It was seen by Forskal at Constantinople; but appears to have remained unknown in Greece and Egypt.

The "ribes sylvestre" of Tragus, and the "r. nigrum" of Dodonæus and Dalechamp, are referred by C. Bauhin and Willdenow to the black currant of the gardens (Ribes nigrum).-This plant appears to have remained unknown in Greece and Egypt.

The Scirpus lacustris is noticed by Tragus, C. Stephanus (p. 520), Gesner, Lobel, and 
1544. - This species of rat is described by Gesner; is regarded as an American animal by Linnæus and Pallas; and by Bartram (quoted by Kalm ii. 47) and Bachman, as indigenous in the United States.

The brown rat (Mus decumanus), though apparently a native of Southeastern Asia, is said to have reached Europe at a somewhat later period.-This is probably the species of rat, which is now common in Egypt.

According to Sprengel, China root is described by Amatus Lusitanus, and by Garcias.-The living plant, Smilax china, was seen by Kaempfer and Thunberg in China and Japan: Alpinus and Forskal (Mat. Med.) speak of the medicinal use in Egypt of the imported root.*

The "arbre de vie de Canade," known to Belon in A. D. 1553, is clearly the Thuya Occidentalis.-The introduction of this tree into Egypt, appears to have been much more recent; according to Clot-Bey and Figari, it is now common in gardens at Cairo.

The musk duck (Anas moschata), a native of Tropical America, is figured by Belon.-At the present day, the domesticated bird is common in most parts of the globe; and from a remark by Clot-Bey, appears to be known in Egypt. $\dagger$

The "anacardum Indis familiaris" of C. Stephanus, A. D. 1554, is doubtless the Anacardium Occidentale.-The tree was seen by Acosta

C. Bauhin.-The plant was seen in Greece by Sibthorp and Bory de St. Vincent; but appears to have remained unknown in Egypt.

The Solanum dulcamara is figured by Tragus and by Matthioli.-The plant does not well accord with the natural vegetation of Europe: it was seen in Greece by Sibthorp; but appears to have remained unknown in Egypt.

* According to Sprengel, The Agave Americana is described by Lopez de Gomara, and is figured by Camerarius. - The plant (according to Sieber and Bory de St. Vincent) has become naturalized in Greece; but I have met with no evidence of its being known in Egypt.

According to Sprengel, Chocolate, and the tree which produces it, Theobroma cacao, are described by Lopez de Gomara._Chocolate has doubtless been sometimes imported into Egypt, but I have met with no direct evidence of the fact.

According to C. Bauhin, Barcia, and Sprengel, The Mimosa pudica is described by Lopez de Gomara, Acosta, and Martinus del Barco.- The plant was seen by Graham in gardens at Bombay; but appears to have remained unknown in Egypt.

The "manga" of J. C. Sealiger and Garcias, is referred by C. Bauhin, Willdenow, and others, to the mango (Mangifera Indica).-The tree is cultivated in Yemen, and doubtless the seeds have been sometimes brought into Egypt, but I have met with no direct evidence of the fact.

+ The "cerasus trapezuntina," stated by Belon to have been brought from Trebizond, is referred by C. Bauhin to the Diospyros lotus.-This plant was received by Matthioli 
in gardens at Cochin in Hindostan. Clusius speaks of the nuts being brought from Brazil to Lisbon; and Rouyer found them imported by the way of Europe into Egypt.

According to Sprengel, Hieronymus Benzoni (who returned from the West Indies in A. D. 1556) describes "petum," or tobacco, (Nicotiana tabacum).-This species of Nicotiana is figured by Monardes, Lobel, and Camerarius; and the N. rustica, by Matthioli and Lobel. Lane states, That the use of tobacco was introduced into the East at the close of the Sixteenth Century: and according to Forskal, Delile, and Clot-Bey, both species are cultivated in Egypt. It is worthy of note, that the custom most prominently distinguishing the present from all former ages, was taught by the Aboriginals of America**

The tomato of Peru (Solanum lycopersicum) is noticed by Gesner, Anguillara, Lobel, Camerarius, and C. Bauhin. - The plant was seen by Delile in Egypt; where, according to Clot-Bey and Figari, it is now abundantly cultivated.

According to Sprengel, The morning-glory (Ipomæa nil, also called I. hederacea) is described by Gesner.-The plant is figured by Lobel (Stirp. hist. p. 340); and was seen by Forskal in gardens at Cairo.

The Canna Indica is noticed by Gesner, Lobel, and Camerarius: and was derived, according to C. Bauhin, from seeds brought from the West Indies to Portugal.-The plant was seen by Forskal, Delile, and others,

from Busbecke at Constantinople; and was also seen at Constantinople by Forskal and Sibthorp; but appears to have remained unknown in Greece and Egypt. Bung found it indigenous on the mountains of Northern China.

According to Clusius and Beckmann, About the middle of the Sixteenth Century, roots of the crown-imperial (Fritillaria imperialis) were brought from Persia to Constantinople, and thence to Vienna; from which city they were distributed over Europe.-The plant is figured by Dodonæus and by Lobel; but I have met with no evidence of its being known in Egypt.

According to Balbinus and Beckmann, The tulip (Tulipa Gesneriana) was brought from Constantinople, probably by Busbecke, about A. D. 1554.-The plant is a native of the Caucasian countries. It was seen by Rauwolf in gardens upon Lebanon; but I have met with no evidence of its being known in Egypt.

According to Beckmann, the Canary bird (Fringilla canaria) is first mentioned by Gesner, A. D. 1555; and is first figured by Aldrovandus.-The bird is a native of the Canary Islands; and has doubtless been sometimes kept in cages in Egypt; but I have met with no record of the fact.

* An account of the horse-chestnut (Asculus hippocastanum) was sent by Quakelbeen at Constantinople to Matthioli, in A. D. 1557.-The tree appears to have remained unknown in Egypt; and indeed, is not successfully cultivated as far South in the United States. 
in the gardens of Egypt; and Delile met with seeds in the drug shops at Cairo.

According to C. Bauhin, Willdenow, and Chaubard, The sainfoin (Onobrychis sativa) is noticed by Gesner, Dodonæus, Thalius, and Lobel.-The plant appears to have been first employed for agricultural purposes about a century later. It was seen in Greece by Bory de St. Vincent; and according to Clot-Bey and Figari, has been recently introduced into Egypt.*

The Melia azedarach is figured by Matthioli.-The tree was seen by Rauwolf and Hasselquist in Palestine; and by Forskal and Delile, in gardens at Cairo.

According to Sprengel, The Dracocephalum Moldavicum, a native of Siberia, is figured by Matthioli.-The plant, according to Clot-Bey and Figari, has been recently introduced by the way of France into Egypt.

According to Sprengel, The Ligusticum Peloponnense is noticed by Matthioli.-The plant grows wild on the mountains of Carniolia; but has not been found in Greece; and according to Clot-Bey and Figari, has only recently been introduced into Egypt.

In "A. D. 1566," the accession of Selim II., the third Turkish sultan who ruled Egypt, took place.

An account of the sunflower (Helianthus annuus) was sent by Cortusi to Matthioli, and was published in A. D. 1568. - The sunflower is also figured by Dodonæus and Monardes; and is enumerated by Forskal, Delile, and Clot-Bey, among the garden plants of Egypt.

The Narcissus jonquilla is noticed by Dodonæus, A. D. 1569; and also by Linnæus.-The plant is supposed to be a native of Spain: it

* The Abutilon vulgare is noticed by Gesner, Anguillara, Matthioli, Dodonæus, Camerarius, and C. Bauhin.-The plant has become naturalized in some parts of Europe; but appears to have remained unknown in Greece and Egypt.

The "alsine glutinosa" of Gesner, and the "auricula muris" of Dodonæus, are referred by C. Bauhin and Willdenow to the Cerastium viscosum and C.vulgatum.-These are enumerated by Sibthorp and Bory de St. Vincent as common weeds in Greece; but no species of Cerastium has hitherto been observed in Egypt.

The Periploca Græca is noticed by Gesner, Matthioli, Lobel, Camerarius, Clusius, and C. Bauhin.-The plant does not well accord with European vegetation. It was seen by Sibthorp in hedges in Northern Greece; and according to Persoon, is found in Syria ; but it appears to have remained unknown in Egypt.

The Hyacinthus Orientalis, supposed to have been brought from Constantinople, is noticed by Gesner, Matthioli, Dodonæus, Castor Durantes, Lobel (who first saw it "in A. D. 1562"), and C. Bauhin.-The plant was seen in Greece by Bory de St. Vincent and Gittard; but appears to have remained unknown in Egypt. 
is enumerated by Clot-Bey and Figari, as cultivated for ornament in the gardens of Egypt.

The pumplin (Cucurbita pepo) is described by Dodonæus.-The plant, according to Dr. T. W. Harris, was derived from the aboriginals of America. It was seen by Forskal and Delile in Egypt; where its name, "kara estombouli" or gourd of Constantinople, indicates a northern route of introduction.

According to Dr. T. W. Harris, the squash (Cucurbita polymorpha) was derived from North America; and is the "askútasquash," cultivated by the aboriginals of New England, mentioned by Josselyn, Wood, and R. Williams. The plant is described by Dodonæus.-Delile is perhaps the earliest writer who mentions the presence of the C. polymorpha in Egypt; where its name, "kara mogrebi" or western gourd, indicates a Mediterranean route of introduction.

The "nasturtium Indicum" of Dodonæus, Monardes, and Lobel (Stirp. Hist., p. 338), is referred by C. Bauhin and Willdenow to the Tropoeolum minus, a native of Peru.-This has become a well-known garden plant; and was seen by Delile, and by Clot-Bey and Figari, cultivated in Egypt.*

According to Sprengel, The Copaifera officinalis, an indigenous tree of Brazil, is described by Lerius.-Forskal (Mat. Med.) speaks of the importation of "copaivæ" balsam into Egypt.

The "mandobi" seen by Lerius cultivated in Brazil, is referred by Monardes, Piso, and others to the pea-nut (Arachis hypogea).-This plant is said to have been long known in China and Cochin China; and, according to Purchas, also in Equatorial Africa. It is now culti-

* According to C. Bauhin and Willdenow, The Celosia coccinea is figured by Dodonæus.-I have met with no evidence, that this plant is known in Egypt.

The Hemerocallis fulva is figured by Dodonæus.-The plant was seen by Kaempfer and Thunberg, cultivated and growing spontaneously in Japan ; but appears to have remained unknown in Egypt.

According to Willdenow, the Hibiscus palustris is figured by Dodonæus.-This is a North American plant; which appears to have remained unknown in Egypt.

The "syringa" of Dodonæus, Lobel (Stirp. Hist.), and Cæsalpinus, is referred by C. Bauhin and Willdenow to the Philadelphus coronarius.-This plant appears to have remained unknown in Greece and Egypt.

The "flos tygridis" sent by Brancion to Dodonæus and Lobel (Stirp. Hist. p. 59), is referred by Dalechamp and others to the tiger-lily (Tigridia pavonia), a native of Mexico. -The plant has become common in gardens; but appears to have remained unknown in Egypt. 
vated in Egypt, as appears from Clot-Bey and Figari ; and its Egyptian name indicates, that the plant was received from Sennaar.

The Laurus sassafras is figured by Monardes; who states, that it was known to him in A. D. 1571, and was brought from Florida.Forskal enumerates "sassafra" wood among the articles of the Egyptian Materia Medica; imported by the way of Greece.

In "A. D. 1574," the accession of Amurath III., or Murad III., the fourth Turkish sultan who ruled Egypt, took place. Robbers having become numerous among the population of Egypt, the pasha sent by him, is said to have decapitated not less than "ten thousand" (Marcel, p. 200). Coins issued at Cairo during the reign of Murad III., are figured by Marcel, p. 202.

According to Lobel, The Convolvulus althooides is described by Clusius.-The plant was seen by Sibthorp in Greece; by myself, at Malta ; and by Delile, at Alexandria.*

According to Sprengel, the weeping willow (Salix Babylonica) was seen by Rauwolf in Palestine.-Forskal and Delile met with the tree in Egypt; where it is now common in gardens.

According to Barcia and Sprengel, The Passiflora cormulea is described by Martinus del Barco, A. D. 1581.-The plant was seen by Forskal at Constantinople; and by Forskal, Delile, and others, in gardens at Cairo.

The Balanites was seen at Cairo by Alpinus in A. D. 1583, and subsequently by Vesling. - The tree (according to Figari and Lloyd) has disappeared from Lower Egypt: it was seen in Upper Egypt by Vansleb, Lippi, and Delile; and by Cailliaud, growing along the Nile from Sennaar to Fazoglo. In Darfour, Browne found the tree regarded as brought from Arabia : it was seen in Arabia by Forskal ("haledj," p. 197); but having also been seen in Hindostan by Royle, in Senegal by Adanson, and in St. Domingo by Poiteau, some doubt has arisen as to the true place of origin. $\dagger$

The " magnæ admirationis herba Peruviana" of Lobel, Tabernæmontanus, and Clusius (Hist. ii. p. 87), is referred by C. Bauhin and Will-

\footnotetext{
* According to Linnæus and Persoon, The Prunus laurocerasus was introduced into Europe in A. D. 1576.-The tree is figured by Camerarius; and was seen in Greece by Sibthorp; but it appears to have remained unknown in Egypt.

† The "quamoclit" of Cæsalpinus, Camerarius, and Clusius, is referred by C. Bauhin and others to the Ipomaea quamoclit.-I found this plant cultivated in gardens at Bombay; but I have met with no evidence, that it is known in Egypt.
} 
denow to the Mirabilis Jalapa.-This plant is figured by Rheede and by Rumphius, as cultivated for ornament in Hindostan and Amboyna; and was seen in Egypt by Hasselquist, Forskal, and Delile, sometimes bearing the name "yimani," which indicates a Yemen route of introduction.

A branch of the Cacatia Kleinia was sent by Garetus to Clusius in A. D. 1593 (Exot. i. 5).-The plant is usually regarded as a native of the Canary Islands: but it was seen by Graham and Gibson, growing on the rocky hill-tops of Western Hindostan. According to Clot-Bey and Figari, the C. Kleinia is now planted in the gardens of Egypt.*

According to Beckmann, The tuberose (Polianthes tuberosa) was procured from the East Indies by Simon de Tovar, prior to A. D. 1594; and was communicated to Bernard Paludanus, who published a description in Linschoten's Voyage--Rumphius, however, speaks of it as an introduced plant at Amboyna; and according to Ruiz and Pavon, it is a native of Peru. The tuberose was seen by Hasselquist, Forskal, Delile, and Clot-Bey, cultivated in the gardens of Egypt.

In "A. D. 1595," the accession of Mohammed III., the fifth Turkish sultan who ruled Egypt, took place. Coins issued at Cairo during his reign, are figured by Marcel, p. 204.†

Gerarde, A. D. 1597, notices the introduction into England of the Yucca aloifolia. - This plant is a native of Carolina; is figured by Parkinson and by Dillenius; and according to Clot-Bey and Figari, is now cultivated in the gardens of European residents in Egypt.

According to Sprengel, The Zapania nodiftora is described by Fer-

\footnotetext{
* In the same year, according to Beckmann, roots of the Amaryllis formosissima were procured from South America by Simon de Tovar, and were communicated to Clusius and to Bernard Paludanus. - The plant appears to have remained unknown in Egypt.

The "grossularia spinosa fruet. purpurasc." seen by Clusius at Leyden in A. D. 1594 (Rarior. i. 85), may be compared with the Ribes gracile of North America.-This species of gooseberry is sometimes cultivated for the sake of the fruit; it appears to have remained unknown in Egypt.

† Seeds of the Argemone Mexicana were received from England by C. Bauhin, in A. D. 1596.-The plant is also noticed by Ferrandus Imperatus; and was seen in Surinam by Merian : it is now cultivated and naturalized in Hindostan; but appears to have remained unknown in Egypt.

A rattan, or stem of Calamus rotang, is figured by C. Bauhin (in Matthiol. p. 58), A. D. 1598.- The living plant (described by Bontius) is a native of the Malay countries; and according to Graham, also of Hindostan. Rattans, being often used in enveloping merchandise, have doubtless been sometimes brought into Egypt; but I have met with no direct evidence of the fact.
} 
randus Imperatus, A. D. 1599.-The plant is noticed by C. Bauhin; was seen by Sibthorp in Greece; by Forskal and Delile, at Cairo and Rosetta ; and I met with it, growing as a weed on the alluvial flats of Upper Egypt.

According to Sprengel, The Cyperus articulatus was discovered in Mexico by Hernandez, A. D. 1600.-The plant was seen by Forskal and Delile, growing as a weed in the rice grounds of Egypt.

In "A. D. 1603," the accession of Achmed or Achmet, the sixth Turkish sultan who ruled Egypt, took place.

According to Pereira, The earliest notice of gamboge (the product of Hebradendron gambogioides) is by Clusius; who in the last-named year, received some by the way of Amsterdam from China.-Rouyer found gamboge sold in the drug shops at Cairo.*

According to Sprengel, The North American strawberry (Fragaria Virginiana) is described by Besler, A. D. 1613.-Clot-Bey and Figari speak of the recent introduction and successful cultivation of the strawberry in Egypt. The species, is probably the North American; which furnishes the most approved garden varieties.

The Helianthus tuberosus is figured by Fabius Columna, A. D. 1616. - The plant is now cultivated in Hindostan, as appears from Graham; and according to Clot-Bey and Figari, has been recently introduced into Egypt.

In "A. D. 1617," the accession of Mustafa, the seventh Turkish sultan who ruled Egypt, took place.

In "A. D. 1623," the accession of Amurath IV. or Murad IV., the eighth Turkish sultan who ruled Egypt, took place. Coins issued at Cairo during his reign, are figured by Marcel, p. 215.†

According to Sprengel, The Acacia Farnesiana is described by Tobias Aldinus, A. D. 1625, and by Hyacinthus Ambrosinius.-The plant is figured by Parkinson; and was seen by Hasselquist, Forskal, and Delile, in the gardens of Egypt.t

* The "hyosciamus Virginianus" of Alpinus, is referred by C. Bauhin, Willdenow, and others, to the Enothera biennis.-This plant has become naturalized in Northern Europe; but appears to have remained unknown in Greece and Egypt.

†The "botrys ambrosiodes Mexicana" of C. Bauhin (Pinax 520), A. D. 1623, is referred by Sprengel to the Chenopodium ambrosioides.-This plant was seen by Forskal at Constantinople; and according to Bory de St. Vincent, has become naturalized in Greece; it appears, however, to have remained unknown in Egypt.

$\$$ According to Cornuti, The Antholyza Ethiopica, of Austral Africa, first flowered at Paris in A. D. 1633.-The plant has become common in greenhouses; but appears to have remained unknown in Egypt. 
The North American locust, Robinia pseudacacia, is figured by Cornuti (64), A. D. 1635.-The tree, according to Clot-Bey and Figari, is now planted in gardens at Cairo.

According to Sprengel, The Eleusine coracana was seen in Egypt by Vesling, A. D. 1638; and in Malta, by Cavallini.-This grain is abundantly cultivated in Hindostan and on the Eastern coast of Africa; but is no longer to be found in Egypt.

In "A. D. 1640," the accession of Ibrahim, the ninth Turkish sultan who ruled Egypt, took place. Coins issued at Cairo during his reign, are figured by Marcel, p. 219.

In "A. D. 1648" (Marcel), the accession of Mohammed IV., the tenth Turkish sultan who ruled Egypt, took place.

According to Aiton, The Celtis Occidentalis was discovered in Virginia by Tradescant, and was introduced into England in A. D. 1656.-It is enumerated by Clot-Bey and Figari, among the trees now planted in the gardens of Egypt.

According to Sprengel, The ipecacuanha plant (Psychotria emetica) is described by Piso and Maregrave, A. D. 1658.-Forskal (Mat. Med.) speaks of the importation of ipecacuanha by the way of Europe into Egypt.

The "camara" figured by Piso and Marcgrave, p. 177, is clearly the Lantana camara.-This shrub, according to Clot-Bey and Figari, is now planted in the gardens of Egypt.*

According to Cornuti and Beckmann, The Amaryllis Sarniensis first flowered in Europe in A. D. 1634.-The plant was ascertained by Kaempfer to be a native of Japan; it appears to have remained unknown in Egypt.

The Ampelopsis hederacea, of North America, is figured by Cornuti, 41.-This ornamental vine was seen by Sibthorp at Constantinople; but appears to have remained unknown in Egypt.

The trumpet-flower (Bignonia radicans), a native of North America, is figured by Cornuti, 42.-The plant appears to have remained unknown in Egypt.

The Datura stramonium is figured by T. Johnson (Ger. Emen., p. 348), A. D. 1636. -The plant has become naturalized in Europe; and was seen in Greece by Sibthorp and Bory de St. Vincent; but it appears to have remained unknown in Egypt and Hindostan.

The "rosa Batavico-Indica" seen by Bontius in Java, is referred by Piso and others to the Hibiscus rosa-Sinensis.-This has become a common greenhouse plant; but it appears to have remained unknown in Egypt.

* According to Sprengel, The Amaranthus viridis is described by Piso and Maregrave, 241.-It is mentioned by Graham, as a common weed in Hindostan : but appears to have remained unknown in Egypt.

According to Linnæus and Persoon, The Melianthus major was introduced into Europe 
According to Sprengel, The Poinciana pulcherrima is described by Zannoni, A. D. 1675.-The plant is figured by Rheede and by Rumphius, as cultivated for ornament in Hindostan and Amboyna; and according to Clot-Bey and Figari, is now common in gardens at Cairo.

The custard apple (Annona squamosa) is figured by Rheede and by Rumphius, as cultivated in Hindostan and Amboyna.-The plant was seen by Forskal and Delile in gardens at Cairo; where, according to Clot-Bey and Figari, it now produces fruit.

The Chrysanthemum Indicum is figured by Rheede and by Rumphius, as cultivated for ornament in Hindostan and Amboyna.-The plant (under the synonym of Anthemis grandiflora) is enumerated by ClotBey and Figari, as now common in the gardens of Egypt.

The Euphorbia tirucalli is figured by Rheede and by Rumphius, as growing in Hindostan and Amboyna.-The plant was seen by Delile, cultivated in a garden at Cairo.*

According to Sprengel, The Vinca rosea is figured by Cleyer (who returned from Japan about A. D. 1680.) - The plant was also seen in Japan by Thunberg: according to Clot-Bey and Figari, it is now common in the gardens of Egypt. $\dagger$

from Austral Africa in A. D. 1672.- The plant is figured by Hermann; and has become common in greenhouses; but it appears to have remained unknown in Egypt.

According to Chaubard, The Erigeron Canadense is figured by Boccone (Sic. t. 86), A. D. 1674.-The plant is noticed by Zannoni and Tournefort; has become a common weed in Europe, and was seen in Greece by Sibthorp; but it appears to have remained unknown in Egypt.

* The Cycas circinalis is figured by Rheede and by Rumphius.-The plant has become common in greenhouses; but appears to have remained unknown in Egypt.

† According to Sprengel, The Gardenia florida is figured by Cleyer.-The plant was again seen in Japan by Kaempfer and Thunberg: it has become common in grecnhouses; but appears to have remained unknown in Egypt.

According to Sprengel, The Pittosporum tobira is figured by Cleyer.-The plant was again seen in Japan by Kaempfer : it has become common in greenhouses; but appears to have remained unknown in Egypt.

According to Sprengel, The Lagerstromia Indica is described by Cleyer.-The plant was again seen in Japan by Kaempfer and Thunberg: it has become common in greenhouses; but appears to have remained unknown in Egypt.

The Xanthium spinosum is described by Morison and by Magnol.-The plant, according to Bory de St. Vincent, is now abuodantly naturalized in Greece; it appears to have remained unknown in Egypt.

The Justicia adhatoda is figured by Hermann (Lugd. t. 643), A. D. 1687 ; and also by Plukenet.-The plant is supposed to be a native of Hindostan; and is planted there in gardens; but it appears to have remained unknown in Egypt. 
In "A. D. 1687," the accession of Suliman III., the eleventh Turkish sultan who ruled Egypt, took place.

The Gossypium vitifolium, is figured by Rumphius, A. D. 1690.The plant was seen by Forskal, cultivated in Yemen; and by Forskal and Delile, in gardens at Cairo and Rosetta.

The Urtica nivea, is figured by Rumphius; and according to Loureiro, has been long cultivated in China and Cochin-China for making cordage.-According to Clot-Bey and Figari, the plant has been recently introduced by the way of France, and is now successfully cultivated in Egypt.

The Spilanthus acmella, an Indian weed, is figured by Rumphius, Plukenet, and Seba.-The plant, according to Clot-Bey and Figari, has been recently introduced by the way of France into Egypt.

In the last-named year, the Asclepias fruticosa (Gomphocarpus) was brought from Austral Africa by Oldenland (Hermann, Parad. Batav. p. 24). - The plant is also figured by Plukenet; was seen by Delile in Egypt, in a single garden; but according to Clot-Bey and Figari, has since become more abundant.

According to Aiton, the Pelargonium capitatum of Austral Africa, was introduced into England in the same year.-It is described by Cavanilles; and is enumerated by Clot-Bey and Figari among the garden plants of Egypt.

In "A. D. 1691," the accession of Achmed II. or Achmet II., the twelfth Turkish sultan who ruled Egypt, took place.*

According to Sprengel, The Mesembryanthemum crystallinum is described by Volckamer (who died A. D. 1693). - The plant is said to

* The Ageratum conyzoides is figured by Plukenet (Phyt. 88), and by Sloane.-It has become a common weed in most Tropical countries; but appears to have remained unknown in Egypt.

The Kerria Japonica is described by Kaempfer (who returned from Japan in A. D. 1692), and by Thunberg. - The plant has become common in gardens; but appears to have remained unknown in Egypt.

The Camellia Japonica was seen by Kaempfer and Thunberg, growing spontaneously in Japan. - The plant has become common in greenhouses; but appears to have remained unknown in Egypt.

The Saxifraga sarmentosa was seen by Kaempfer and Thunberg, indigenous on the mountains of Japan.-The plant has become common in greenhouses; but appears to have remained unknown in Egypt.

The Hemerocallis Japonica was seen by Kaempfer and Thunberg, cultivated and growing spontaneously in Japan.-The plant has become common in greenhouses; but appears to have remained unknown in Egypt. 
have been found by Thunberg, indigenous in Austral Africa. It was seen by Sibthorp, naturalized within the limits of the city of Athens; and by Delile, at Alexandria.

In "A. D. 1695," the accession of Mustafa II., the thirteenth Turkish sultan who ruled Egypt, took place.*

The Acacia lebbeck is figured by Plukenet. - The tree was seen by Forskal and Delile at Cairo; where it has become common in gardens. It was also seen by Forskal, cultivated in Yemen; and according to Graham, is well known in Hindostan.

The ash-leaved maple of North America, Acer negundo, is figured by Plukenet, 123.-The tree, according to Clot-Bey and Figari, is now planted in the gardens of Egypt.

The Phytolacca decandra, a North American weed, is described by Plukenet and by Tournefort.-The plant, according to Sibthorp, has become naturalized in Greece; it was seen by Forskal and Delile, growing spontaneously at Cairo.

The Cassia Occidentalis is figured by J. Commelyn, A. D. 1697, and by Sloane.-The plant is now naturalized in most Tropical countries; and was seen by Delile in gardens at Cairo. $t$

The vanilla plant (Vanilla aromatica), a native of Mexico, is described by Plukenet, Catesby, and Schwartz.-According to Clot-Bey and Figari, the living plant has been recently introduced, and is now successfully cultivated in Egypt.

According to Loudon, the Gleditschia triacanthos of North America was introduced into the English gardens in A. D. 1700.-The tree is enumerated by Clot-Bey and Figari, as planted in the gardens of Egypt.

In "A. D. 1703," the accession of Achmed III. or Achmet III., the

* The Asclepias Curassavica is figured by Hermann (who died in the last-named year), and by Sloane.-The plant has become naturalized in most Tropical countries; but appears to have remained unknown in Egypt.

The Sicyos angulata is figured by Hermann (Parad. Batav., p. 133).-The plant was seen by Thunberg in Japan; and is abundantly naturalized in the United States; but it appears to have remained unknown in Greece and Egypt.

The Amaryllis belladonna, a native of Tropical America, is figured by Hermann (Parad. Batav. p. 194), and by Seba.-The plant has become naturalized in Madeira; but appears to have remained unknown in Greece and Egypt.

$\dagger$ The Agapanthus umbellatus is described by J. Breynius (who died in the last-named year).-The plant has become common in Northern greenhouses; but appears to have remained unknown in Egypt.

The Mollugo verticillata, a North American weed, is figured by Plukenet (Mant. tab. 332).-The plant appears to have remained unknown in Greece and Egypt. 
fourteenth Turkish sultan who ruled Egypt, took place. Coins issued at Cairo during his reign, are figured by Marcel, p. 225.

In the same year, the Polygonum Orientale is said to have been brought from the Levant by Tournefort.-The plant was seen by Delile in gardens at Cairo.*

In "A. D. 1707" (Marcel, p. 221), a change took place in the internal affairs of Egypt. The authority of the pasha sent from Constantinople became chiefly nominal; while from this time, the administration was really conducted by the Schekh-el-beled, Ismael-Bey, and his successors in the office.

According to Aiton, The Pelargonium zonale, a native of Austral Africa, was introduced into the English gardens in A. D. 1710.-The plant is figured by Cavanilles: and is enumerated by Clot-Bey and Figari, as cultivated for ornament in the gardens of Egypt.

The Momordica pedata is figured by Feuillee (who returned from Peru in A. D. 1711).-The plant was seen by Delile in gardens at Cairo. $\dagger$

According to Sprengel, The Poa pilosa is described by Scheuchzer, A. D. 1719.-The plant has not been found in Greece; but was received from Italy by Linnæus; and was seen by Delile, growing spontaneously at Cairo.

The catalpa (Bignonia catalpa) is figured by Catesby (who returned from Carolina in A. D. 1726).- The tree, according to Clot-Bey and Figari, has been recently introduced into Egypt.

In "A. D. 1730," the accession of Mahmood, the fifteenth Turkish sultan who ruled Egypt, took place.-Coins issued at Cairo during his reign, are figured by Marcel, p. $229 . \S$

* The Triticum repens is described by Tournefort.-The plant was seen by Forskal at Constantinople; and according to Sibthorp, is common in Greece; but it appears to have remained unknown in Egypt.

† According to Sprengel, The Nicandra physalodes is figured by Feuillee.-The plant has become naturalized in the United States and in Hindostan; but appears to have remained unknown in Greece and kgypt.

† The Hordeum jubatum is figured by J. C. Buxbaum; who met with it, growing spontaneously at Smyrna.-The plant was again seen at Smyrna by Sibthorp; and on the island of Milo by D'Urville; but appears to have remained unknown in Egypt.

$\S$ The Aster Chinensis is figured by Dillenius, A. D. 1732, and by Knorr.-The plant has become common in gardens; and was seen by Forskal at Constantinople; but appears to have remained unknown in Egypt.

The North American black currant, Ribes floridum, is figured by Dillenius.-The plant has become common in gardens; but appears to have remained unknown in Greece and Egypt. 
Leersia oryzoides is described by Linnæus, A. D. 1753, and by Schreber.-The plant was perhaps derived from North America; but is now found in Central Europe; and was seen by Delile at Rosetta and Damietta.

In "A. D. 1754," the accession of Osman II. or Othman II., the sixteenth Turkish sultan who ruled Egypt, took place.

In "A. D. 1757," the accession of Mustafa III., the seventeenth Turkish sultan who ruled Egypt, took place. Coins issued at Cairo during his reign, are figured by Marcel, p. 239.

Sterculia platanifolia, according to Aiton, was cultivated in England in the last-named year.-Six years later, the tree was seen by Forskal among the mountains of Yemen; where it was called "kulham." It is enumerated by Clot-Bey and Figari, as now planted in the gardens of Egypt.

In "A. D. 1768" (Marcel), war was declared between Russia and Turkey; and Egypt was called upon to furnish "twelve thousand men." At this time, the Memluk chieftain, Ali-Bey, having acquired great influence in Egypt, and the sultan failing in an attempt to get rid of him, declared himself independent; and maintained his position for about four years. Coins issued by him, are figured by Marcel, p. 335 .

Phytolacca dioica, a native of Tropical America, was cultivated in England by Miller in the last-named year.-The plant is figured by L'Heritier; is described by Aiton; and according to Clot-Bey and Figari, has been recently introduced into Egypt.

Phormium tenax, the New Zealand flax, was discovered by Cook and Forster in New Zealand, in A. D. 1773.-The plant, according to ClotBey and Figari, has been recently introduced by the way of France into Egypt.

In "A. D. 1774," the accession of Abd-el-Hamid, the eighteenth Turkish sultan who ruled Egypt, took place. Coins issued at Cairo during his reign, are figured by Marcel, p. 249.

Polygonum tinctorium, used for dyeing in China, was introduced into England by J. Blake in A. D. 1776.-The plant is described by Aiton, and by Loureiro; and according to Clot-Bey and Figari, has been recently introduced by the way of France into Egypt.

Aloysia citriodora is described by Ortega; and was ascertained by Dombey to be a native of Chili.-It is enumerated by Clot-Bey and Figari among the garden plants of Egypt. 
In " A. D. 1789," the accession of Selim III., the nineteenth Turkish sultan who ruled Egypt, took place. Coins issued at Cairo during his reign, are figured by Marcel, p. 249.

Dahlia variabilis was sent from Mexico in the last-named year to Cavanilles at Madrid.-The plant, according to Clot-Bey and Figari, was introduced by the French into Egypt.

Thalia dealbata, according to Pursh, was discovered by J. Millington in Florida.-Clot-Bey and Figari mention the recent introduction of the plant by the way of France into Egypt.

On the "1st of July, A. D. 1798" (Thiers and Ryme), the French under Bonaparte, after overthrowing the independence of Malta, landed near Alexandria, and obtained possession of Egypt; where they maintained themselves for more than three years.

Euphorbia calendulifolia was discovered by Delile in A. D. 1799, growing as a weed in cultivated fields near Cairo.-Its place of origin remains unascertained.

In "A. D. 1807," the steam engine was applied to navigation with full success by Fulton; the trial of the boat taking place in North America, on the Hudson River.

In the same year, the accession of Mustafa IV., the twentieth Turkish sultan who ruled Egypt, took place. In this year also (Clot-Bey and others), the English took possession of Alexandria; where they maintained themselves for about six months; but were finally forced to re-embark.*

In "A. D. 1808," the accession of Mahmood II., the twenty-first Turkish sultan who ruled Egypt, took place.

The breaking up of the Memluks by the French, and the measures adopted for the expulsion of the latter, led to the introduction into Egypt of a body of four thousand Albanians. These became the source of the power of their chieftain, Mohammed Ali; who, on the "1st of March, A. D. 1811" (Clot-Bey and others), extinguished by violence the remains of the Memluk Aristocracy: and who became virtually independent; and twice rendered European interference indispensable to the preservation of the reigning Dynasty at Constantinople. $\dagger$

\footnotetext{
* This year forms a convenient point of reference to the botanist, from being the date of the concluding volume of the manual of Persoon.

$\dagger$ Coreopsis tinctoria was discovered by Nuttall on the Arkansas River, in A. D. 1819. This soon became a favourite flower, and so widely diffused, that in Brazil, I met with a
} 
In "A. D. 1822" (Brewster's Cycl.), a revolution commenced in Greece: which ended four years later, in the independence of a large portion of the country; partly accomplished through European interference.

In "A. D. 1829," the steam-engine was successfully applied to landtransportation; the trial taking place in England, on the rail-road at Liverpool.

In "A. D. 1832" (Gliddon), the voyages of the English Steamer on the Red Sea commenced. The successful employment of Ocean steamers forms an epoch in Navigation; as also, in international affairs; and at the present moment, is even tending to restore Egypt to her ancient position, as naturally the centre of the routes of intercourse, both by land and sea.

At or near the last-named date, a line of demarcation should be drawn: for a botanic garden under European superintendence has been established in Egypt; and at the time of my visit, it already contained many plants not noticed in these pages. The object could be accomplished, by retaining as notes the long-known species introduced into Egypt after the selected date: but for the present, as I am about taking leave of the whole subject, I will here change the order of enumeration.

Terminalia. Two species, according to Clot-Bey and Figari, are now planted as shade trees in Egypt.

Brugmansia candida, according to Graham, was introduced by the way of Egypt into Bombay, in A. D. 1837.

In "A. D. 1839" (Clot-Bey and others), the accession of Abd-elMedjid, the twenty-second Turkish sultan who ruled Egypt, took place.

Citrus decumana, the shaddock. An expression of Rabbi Schwarz ii. 2, seems to imply, that this fruit has been seen at Jerusalem: the specimens may have been brought from India by the route of the Red Sea; and possibly by steamboat.

solitary plant kept at a window amid the surrounding magnificence of the regetation of the Organ Mountains. According to Graham, the C. tinctoria has become common in the gardens of Hindostan; but I have met with no evidence of its having been introduced into Egypt. 
The foregoing Tabular Arrangement, in its present imperfect condition, will yet be found to throw light on the history of words, and upon the whole subject of Philology. Take, for instance, the question of the origin of the word "cow," and of the time when this word was first used in Fingland?

The animal bearing the name has been the companion of man from the earliest historical records. In Egypt and throughout Arabia, the male is universally called "thour;" in Ancient Palestine (in Hebrew) "thwr;" further north, in Ancient Greece "tayros;" in Ancient Italy "taurus;" in France "taureau," to the very margin of the Channel; over which the word does not appear to have ever crossed into England. Again : in Egypt and throughout Arabia, the female is universally called "bakar;" in Ancient Palestine (in Hebrew) "bkr;" in Ancient Italy "vacca;" in France "vache;" but in like manner, this second word does not appear to have entered England: as though, when the two words arrived at the Channel from the South, the objects in England were already supplied with names.

Turning now to the so-called English word "cow:" which is unknown in the above-named southern countries; but which occurs in Germany; in Northern Europe (in the Scandinavian countries); in Persia; in Ancient Hindostan (in the Sanscrit language); and further east, in China. By what route did the word reach England? and, To what language did it originally belong? If we go back in history four thousand years, to the Twelfth Egyptian Dynasty, we find the word "cow" at that time used in Egypt. (See Bunsen, Anc. Egypt. Vocab.) .

\section{The Egyptian measurement of time.}

Some remarks properly belonging to this head have been already given, in the course of the preceding pages; but a more full explanation has been reserved for this place.

Among the various calendars devised for measuring time, the most simple is the one which follows the period of three hundred and sixtyfive days. The fractional excess of the natural year being excluded, such a calendar at once gives the number of days between two dates; a source, under our own system of intercalation, of perpetual inconvenience to Astronomers and Historians.

Such a calendar, however, is not a fixed one: its initial day does not always keep at the same distance from the solstices and equinoxes, 
but gradually traverses all the seasons, and returns to the starting point. If the length of the natural year was precisely three hundred and sixty-five days and a quarter, the return would take place after an interval of 1460 natural years, and of 1461 calendar years; for

$$
\begin{aligned}
& { }^{\frac{1}{4} \mathrm{t}} \times 1461=365 \frac{1}{4} \text { days } ; \text { and } \\
& 36 \frac{1}{4}^{\mathrm{d}} \times 1460=533,265 \text { days }=365^{\mathrm{a}} \times 1461 \text {; }
\end{aligned}
$$

but the natural year being in reality somewhat shorter than $365 \frac{1}{4}$ days, the return will be proportionably delayed.

An intelligent people would hardly fail to note the return and the real interval. But in Egypt (where this calendar was once in vogue), a peculiar circumstance tends to direct attention to these particulars: for the summer solstice, taking place simultaneously with the commencement of the inundation, regulates the agriculture* and the whole business of the country. No other river, save the Nile, is punctual to a day in its rise; and in no other country, save Egypt, is there an abrupt terrestrial mark of the termination of the natural year. Were it yet possible for a community to overlook such manifest indications, the attention of the Ancient Egyptians was further arrested by stated Sacred Festivals.

The Egyptians used the calendar in question for many centuries, and counted out the interval between the departure of their New Year from the solstice and its return. Various ancient writers speak of the Completion of the Egyptian Cycle; and the date of this Completion has formed the subject of inquiry, as an important point in Chronology.

The length of this Cycle remaining uncertain, and believing, that the experience of the Ancient Egyptians was somewhere recorded, I proposed to myself a search; being aware (from Biot's computation), that if our astronomical measurements of the year are correct, the Cycle should consist of " 1505 years :"

Not long after this, I met with Manilius' account of the phœenix, ... "vivere annis DCLX. . . . Cum huius alitis vita magni conversionem anni fieri prodidit idem Manilius, iterumque significationes tempestatum et siderum easdem reverti: it lives six hundred and sixty years: With the life of this bird, Manilius also relates, the revolving of the Great Year comes to pass, and the signs of the seasons and stars

* Mr. Gliddon informs me, that the Egyptian peasant, or "fellah," without regard to any established calendar, ascertains seed-time by simply counting with his fingers the number of days from "green water :" the name given to the initial day of the inundation. 
again return" (Pliny x. 2). Now, a period of 660 years does not agree with the return of the stars and seasons: but a question arose, Might not this period have formed a division of the Great Year? 21 phœnixes fell below the mark; $2 \frac{1}{2}$ far exceeded it; $2 \frac{1}{3}$ gave 1540 years, which was a possible number. I was now to apply a test; derived from an opinion I had formed, that the Egyptian Cycle was some multiple of 7 . The test appeared to fail in the instance of 660 ; but 1540 years proved to be divisible by 7 ; and when so divided, gave $\frac{1}{3}$ of a phoenix.

I was no longer in doubt, as to the experience of the Ancient Egyptians: and when I had nearly finished printing my work on the Races of Man, an opportunity offered of introducing the subject. It seemed however to be going out of my way, and I had nearly decided in the negative; in a moment of perplexity seeking to divert my thoughts, I took up Fisher's "Dial of the Seasons," a volume chance had placed upon my table. Turning over the leaves, my eye rested on the page treating of the velocity of light; and I perceived, that the time assigned for the passage of light from the sun, was the amount wanting to reconcile the astronomical and Egyptian measurements of the Great Year. Here, was confirmation of a count by the Egyptians; but the accompanying result was unlooked for.

The next step was, to determine with more precision the annual difference. Roemer (as quoted in Herschel's Outlines of Astronomy, 545 ), assigns $8^{\mathrm{m}} 13 \cdot 3^{\mathrm{s}}$ for the passage of light across half the diameter of the earth's orbit. Keeping this in view, I proceeded at first by rough approximations: as

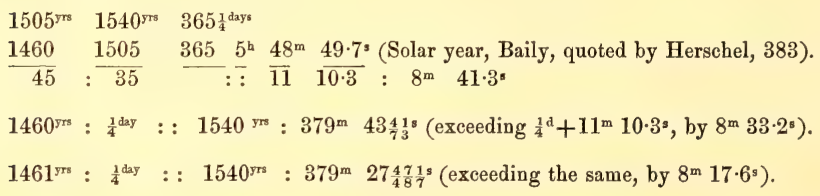

The results obtained by the above approximations are all too large; for

$$
\begin{gathered}
365 \frac{1}{4} \mathrm{~d}-\frac{1}{77}^{\mathrm{d}}=365 \frac{73}{308}=\frac{73}{3}^{\mathrm{d}} \times 1541 ; \text { and } \\
365 \frac{73}{308}^{\mathrm{d}} \times 1540=562,465 \text { days }=365^{\mathrm{d}} \times 1541 ;
\end{gathered}
$$

or in other words, If the natural year were $\frac{1}{77}$ shorter than $365 \frac{1}{4}$ days, the return would take place at the end of 1540 natural years, of 1541 
calendar years, and of precisely 562,465 days. As, however, the Egyptian Endmeration of THE DAYS appears to have gone on without interruption, it seems probable, that the Great Year really consisted of 1540 calendar years, or of 562,100 days: now the nearest of the above approximations,

$$
\begin{gathered}
365^{\mathrm{d}} 5^{\mathrm{h}} 48^{\mathrm{m}} 49 \cdot 7^{\mathrm{s}} \text { (the Solar year) }-8^{\mathrm{m}} 17^{\cdot} \cdot 6^{\mathrm{s}}, \text { or more exactly, } \\
365^{\frac{1}{4} \mathrm{~d}}-19^{\mathrm{m}} 27^{4} \frac{4}{4} \frac{1}{8} 7^{\mathrm{s}} \times 1539=562,098^{\mathrm{d}} 22^{\mathrm{h}} 41^{\mathrm{m}} 38 \frac{27}{4} \frac{4^{\mathrm{s}}}{7^{\mathrm{s}}},
\end{gathered}
$$

gives a difference of more than an entire day.

It was only after my book had been printed and published, that I obtained a number which satisfies all the requirements :

$$
\begin{aligned}
& 1 \text { day }-\frac{2 \frac{1}{3}}{66}=1389_{\frac{6}{6}}{ }^{\mathrm{m}}=1389_{\frac{7}{7}}^{\frac{\mathrm{m}}{3}} \text {; and } \\
& \frac{13897_{77}^{7}}{77}: \frac{1440}{77}:: \frac{1440}{77}: 19 \frac{5177^{\mathrm{m}}}{133} \text { (or } 19^{\mathrm{m}} 23 \frac{1269}{133}^{\mathrm{s}} \text { ). } \\
& \text { From the Solar or Natural year }=365^{\text {d }} 5^{\text {h }} 48^{\mathrm{m}} 49 \cdot 7^{\mathrm{g}} \text {, }
\end{aligned}
$$

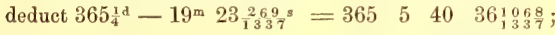

$$
\begin{aligned}
& \text { and the remainder, } \\
& 8 \quad 12 \cdot 9 \text {, }
\end{aligned}
$$

differs only a fraction of a second from Roemer's quantity; a fraction too small to be easily reached by instrumental observation. Granting, however, that it can be reached and rendered sensible; as astronomers use sidereal time, and as everything relating to the Egyptian Great Year is in solar time, the difference between solar and sidereal time proves to be in favour of the new quantity. In regard to the third test, the difference in the length of the Great Year amounting to less than an entire day, might readily escape the notice of the Egyptian community;

$365^{\mathrm{d}} 5^{\mathrm{h}} 40^{\mathrm{m}} 3613 \frac{68}{13} 7^{\mathrm{s}} \times 1539=562,099^{\mathrm{d}} 0^{\mathrm{h}} 43 \frac{1189 \mathrm{~m}}{1337^{2}}$.

Up to this stage in the investigation, I had not doubted the correctness of the received Theory of the progressive motion of light. I had been in search of a smaller quantity than $8^{\mathrm{m}} 12 \cdot 9^{\mathrm{s}}$; for the Sun itself occupying no inconsiderable portion of the diameter of the Earth's orbit, $8^{\mathrm{m}} 12 \cdot 9^{\mathrm{s}}$ do not correspond to the alleged rate of travel from the Sun's surface to our Earth; whether at the Equinoctial points, or even at the average orbital distance. This led to an examination into the origin of the Theory : 
The planet Jupiter presents a system of worlds, which can be rendered visible by any ordinary telescope. The satellites perform their revolutions each in its own time; and these revolutions are of course invariable, like that of the Earth. When however we attempt to measure these revolutions (for we can watch the instant when the satellite dips into Jupiter's shadow), we get an irregularity; or in plainer words, we make mistakes. When the Earth is in a certain part of its orbit, Jupiter's satellites seem to complete their revolutions in $8^{\mathrm{m}} 13 \cdot 3^{\mathrm{s}}$ less than the average period; and when the Earth is in the opposite portion of its orbit, in $8^{\mathrm{m}} 13 \cdot 3^{\mathrm{s}}$ more than the average period. In other words, the revolutions of Jupiter's satellites give the difference between "true" and "apparent" time: between "true" time, as maintained in the System of Jupiter ; and "apparent" time, when we measure from the surface of the Earth. As the Theory stands, the fault is in the light, which does not come fast enough : but the required irregularity has been obtained above, without the aid of Jupiter and his satellites, and by a process which has nothing to do with properties of light.

However singular it may appear, For months I did not think of chronological verification : and after all, the first instance in confirmation of Pliny's statement, came in a measure by chance :

1. One day, on referring to the Old Egyptian Chronicle, I happened to remark the sum of the years in two consecutive lines:

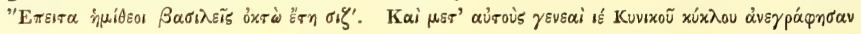

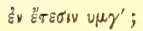

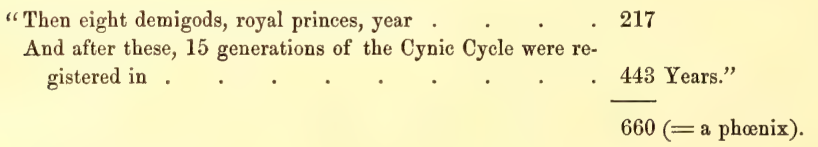

2. Inquiry being once awakened, other instances of conformity were soon discovered: According to Bunsen, the Turin Papyrus (a document in hieratic writing containing the name of no king more recent than Ramses II.) has the following line;

"Kings up to Horus, 23,200 years." $(1540 \times 15=23,100)$.

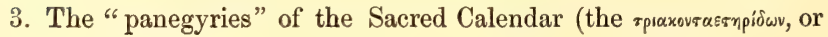


"thirty-year periods," of the Rosetta Stone); for these correspond to the already-given larger Divisions of Time,

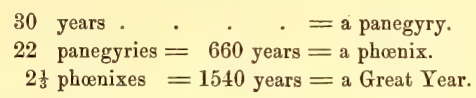

4. Another line in the Turin Papyrus, is given by Bunsen as follows,

$$
\text { “ } 13,420 \text { years.” ( }=1540 \times 9-440=9 \text { Great Years—-2 phœnix.) }
$$

5. According to Julius Africanus, The first book of Manetho's History of Egypt contained the events of

$$
\text { “ } 2308 \text { years } 70 \text { days." ( } 2310=1540+770=1 \frac{1}{2} \text { Great Years). }
$$

6. Claudius Ptolemy, according to his own statement, "made his Observation of the Vernal Equinox in the third year of Antoninus" (A. D. 139, Clinton); and he further names "the seventh of the Egyptian month Pachon," as the equinoctial day. On comparing the fixed and movable calendars, the twentieth of July being the admitted starting place,

$$
\begin{aligned}
& \text { March } 10+\text { April } 30+\text { May } 31+\text { June } 30+\text { July } 19 \\
& \text { Pachon } 23+\text { Paoni } 30+\text { Abib } 30+\text { Misra } 30+\text { Epagomena } 5=\frac{118}{2},
\end{aligned}
$$

we find a deficiency of two days: but morning being the time of adjustment, and the equinox in question taking place "one hour after noon," we may assume a deficiency of $2 \frac{3}{4}$ days; and that the Great Year ended $\left(2 \frac{3}{4} \times 4=\right) 11$ years previously, or in A. D. 128 :

From this date, counting backwards (1540-128 - 1, the latter deduction being required on reversing the order of reckoning), we obtain,

for the commencement of this Great Year,

B. C. 1413.

"Apion placed the Exodus in the 1st yr. 7th Olympiad"

$$
\text { (B. C. 751, Clinton), }
$$
$662(-2=a$ phœnix $)$.

Compare with this, the date of the alleged "burning of Bocchoris by Sabaco;" and Lysimachus' placing "the Exodus under Bocchoris" 
(referring however to a much earlier date than B. C. 751). Compare also, the Era of Nabonassar, "B. C. 747 :" and the Building of Rome, placed by Fabius Pictor (the earliest Roman historian) "in the first year of the eighth Olympiad," or at the commencement of the Era of Nabonassar: Polybius, however, places the Building of Rome "in the second year of the Seventh Olympiad" (the spring of B. C. 750, Clinton, Fast. Hellen. iii. Introd. 19); while Varro's computation, "the third year of the Sixth Olympiad" (B. C. 753), coincides with the date obtained above from Ptolemys' Observation of the equinox; for

$$
\text { B. C. } 1413-\text { B. C. } 753=660 \text { (=a phœnix). }
$$

Pliny $\mathrm{xxx} .3$, makes the following statement, . . . . . "DCLVII demum anno urbis Cn. Cornelio Lentulo P. Licinio Crasso Coss. senatusconsultum factum est ne homo immolaretur: at length in the 657th $(+3=660)$ year of the City, Cn. Cornelius Lentulus and P. Licinius Crassus being consuls, a decree of the senate was passed, that a man should not be sacrificed." The consuls are the same named in Pliny x. 2, where Manilius states of the phonix and Great Year: "Et fuisse ejus conversionis annum prodente se P. Licinio Cn. Lentulo consulibus ducentesimum quintum decimum: and the year of its revolution, $\mathbf{P}$. Licinius and Cn. Lentulus being consuls, was the 215th :"

These consuls are placed by Clinton in B. C. 97

End of the Great Year (by Ptol. Obs.), in A. D. $128(-1)=127$

$$
\overline{224} \text { years ; }
$$

making a surplus over the $\frac{1}{3}$ phoenix, corresponding very nearly to the five years' deficiency given by Manilius. It would seem, therefore, that the Romans, while supposing they were reckoning their years from the Building of the City, really dated from an Egyptian phœix.

The Second Era of Gaza may deserve examination in connexion with the ending of the Great Year. This Era "commenced in A. D. 130 ;" in the same year, Hadrian visited Egypt and left an inscription on the Vocal Memnon at Thebes; which is still legible, and is dated in "the fifteenth year of his reign, the 24th of the Egyptian month Athyr, and the 25th of the Roman month November" (see Clinton).

7. From various considerations, some of them already mentioned, it has been inferred, that the Great Year in question commenced in the reign of Meneptha Sethos: a Pharaoh placed by Lepsius at the 
head of the Nineteenth Dynasty. Manetho's numbers (as transmitted by Julius Africanus, Syncellus, and Routh), below the Nineteenth Dynasty inclusive, are as follows,

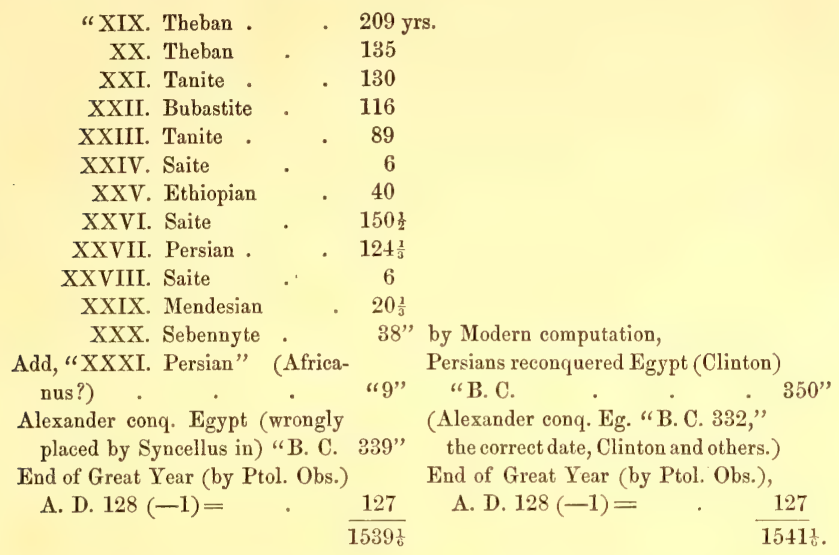

On a monument, discovered and figured by Cailliaud, Ramses II. (the son of Meneptha Sethos) is represented receiving the symbols of two Great Years. It appears therefore, that in B. C. 1413, the Egyptians believed, that two Great Years had been counted out. This corresponds with the statement of the priests to Herodotus ii. 142; and will place the commencement of the Egyptian Chronological Reckoning $(1540 \times 2+1413)$ in B. C. 4493 . Now,

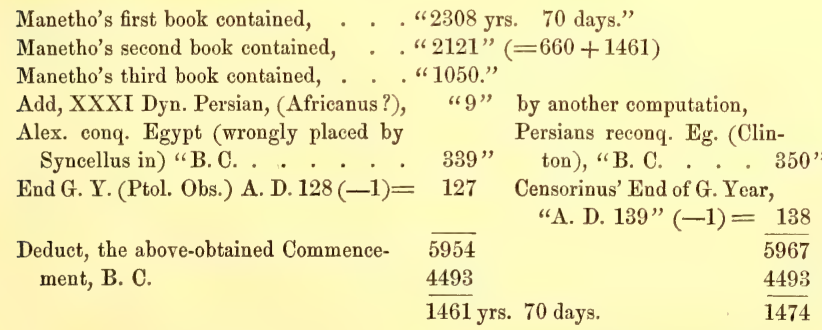

A surplus of 1461 years has thus become evident in the Syncello- 
Africano-Manetho Table of Chronology. The separate Dynasties, however, do not give the same result: though the presence of a large surplus may be inferred; from the years of the Ninth, Tenth, and Eleventh Dynasties, equalling those of the Thirteenth and Fourteenth; and from the discrepancy in the length of Shepherd rule, in Josephus' quotation from Manetho. From the Eighteenth to the Seventh Dynasties inclusive, we count 2812 yrs. 70 days, an excess over a Great Year of 1272 yrs. 70 days; and these precise results will be found expressed by the separate Dynasties, if they are arranged in the following manner:

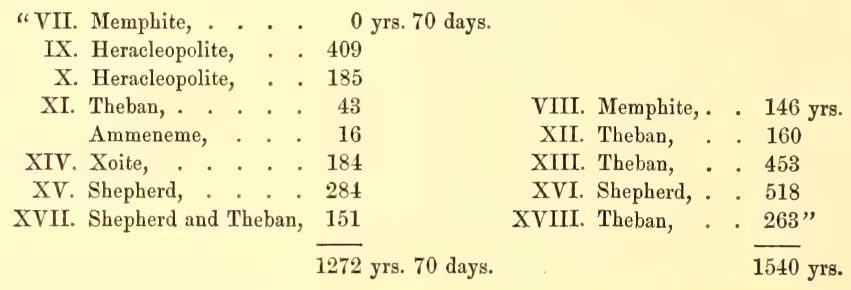

The Second Great Year being thus accounted for, there remains a Third, before reaching the commencement of the Egyptian Chronology. Continuing backwards in the Table, we have,

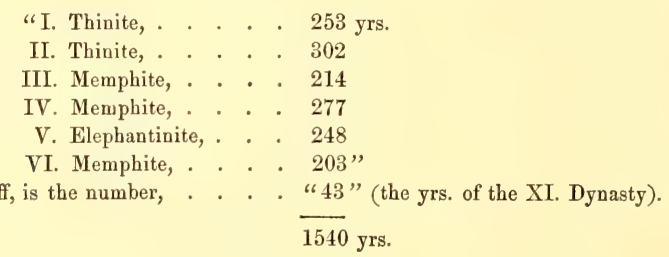

In the two last determinations, I was assisted by a suggestion of C. Muller: That the Nitocris, who closes the Sixth Dynasty, and "her yellow hair and red cheeks," and who (according to Herodotus) "was burned," refers to the phœnix (Fragm. Historic. Græc. vol. ii. p. 520).

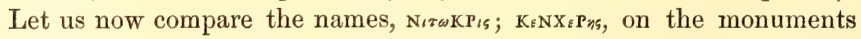
$\mathrm{HoNt}-\mathrm{Re} \mathrm{CHe}$, as read by Champollion (see Champollion-Figeac, Egypte Anc. p. 329); Boxxwors or Borxwpis, pronounced BoNCHoRis; and aCHeRNaR, the Arabic name of the bright star in the constellation 
Phœnix : the terminal $t$ being the sign of the Feminine in the Ancient Egyptian language, and the radical consonants KNR occurring in all the above names, we have in fact but one word differently disguised.

8. The concluding chapter of Herschel's Outlines of Astronomy contains some remarks on the so-called "Jutian Period;" a device, said to have been received "by Scaliger from the Greeks of Constantinople; "and "found so useful, that the most competent authorities have not hesitated to declare that, through its employment, light and order were first introduced into chronology." On examination, the so-called "Julian Period" proves to be adapted to the meridian of Alexandria!

Its initial point is placed at . . . . . . . . "B. C. 4713,"

deduct the above Commencement of Egyp. Chronology, B. C. 4493,

$$
220 \text { (= } \frac{1}{3} \text { phœnix); }
$$

and the remainder, amounting precisely to a third of a phonix, implies absolute connexion.

9. The Old Egyptian Chronicle, at first, does not appear to yield such satisfactory results: for we count,

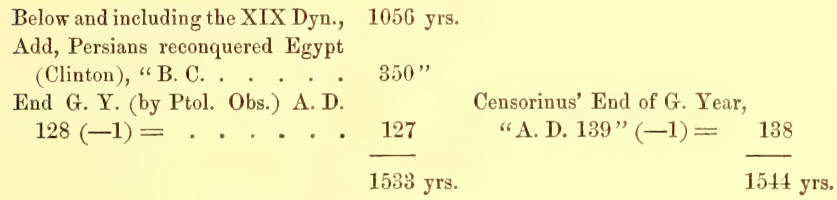

On adding together the years given in the Old Egyptian Chronicle, we find

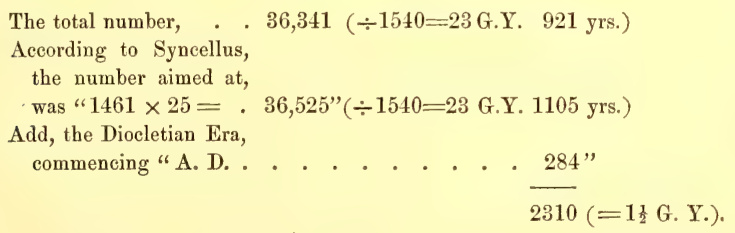

Now, the Diocletian Era is the one used at the present day by the 
Copts: and we may yet be obliged to appeal to Modern Egypt, and the current Reckoning there, to recover the connecting points in our own Chronology.*

10. It appears, from the Old Egyptian Chronicle, as well as from the Africano-Manetho Table of Chronology, that the numbers 1540 and 1461 were both used by the Egyptians in measuring time. Possibly, the latter number may not always stand for years: for there are $(3651 \times 4=) 1461$ days in a quadrennium of our own Calendar; and one hundred of our Calendar years contain " $1461 \times 25=36,525$ " days; a sum, which, by changing the place of the comma, becomes the decimal expression of $365 \frac{1}{4}$.

The Egyptians have long used a Fixed Calendar; and, as described by Lane and others, it does not materially differ from our own. When Augustus visited Alexandria (in B. C. 30), the Egyptian New Year fell on "the 29th of August:" and in modern times, a similar arrangement has been found to exist in several Oriental Calendars. The origin of the practice appears to be connected with the Egyptian Sacred Numbers, 40 and 70 ; the 29th of August, being forty days after the Rising of Sirius (July 20th), and seventy days after the Solstice. In Modern Egypt, we find the New Year no longer "seventy" days from the Solstice; and we thus acquire the means of testing the reality of Precession.

Lepsius is said to have traced the Egyptian Fixed Calendar as far back as the Building of the Pyramids. However this may be, the sign of the quadrennium occurs on the very earliest monuments, and implies, that the Egyptians kept a record of the NATURAL YEARS: either by the approximation of a fourth year intercalation; or they may have used a simple enumeration; the same, perhaps, that afterwards among the Greeks was continued as the "Olympiads."

11. The Ancient Egyptians also enumerated the Lunations: using for this purpose a short Lunar Calendar; which has been traced by Lepsius as far back as the Twelfth Dynasty, and is perhaps the one continued at the present day by the Muslims. This short Lunar

* Some ambiguity arises, in consequence of the Dionysian Era (already noticed in the preceding pages) commencing 284 years before the Christian Era; while the Diocletian, commences 284 years afterwards. Whichever Era may have been employed in connexion with the Old Egyptian Chronicle, the substitution will produce no change in the main results. 
Calendar was not unknown to the Ancient Hebrews; as will appear, on comparing the following names of months:*

HEBREW.

2. 1, Zıou, or Zif (1 Kings vi. 1 and 37 ),

8. בול, B $\alpha \alpha \lambda$, or Bul (1 Kings vi. 38), . אלול, Ėouג, or Elul (Neh. vi. 15, and

1 Macc. xiv. 27), . . . . . .

7. אתנים, Adavw, Ethanim (1 Kings viii. 2),

$\Sigma \varepsilon$ rova入 (Baruch)
MUSLIM.

2. Suf'ar.

3. Rabee'ă el-Ow'wal.

5. Gooma'd el-Ow'wal, or Gooma'da-l-Oo'la.

6. Gooma'd et-Ta'nee, or Gooma'da-t-Ta'niyeh.

10. Show'wa'l.

12. The Third Calendar used by the Egyptians, or the "Sacred" Calendar, which enumerated the DAYS, has been already noticed. It should however be observed, that this Enumeration was regulated and greatly aided by means of thirty-six "deccans;" each bearing a separate name, and consisting of ten days.

13. On proceeding now to our MINOR DIVISIONS OF TIME, the following coincidences may be remarked:

The radius of a circle has been found to describe a hexagon within the circumference.

From remote and unknown Antiquity, it has been the practice, to

* In regard to the date conveyed by the terms in which the Exodus is narrated, It is clear, That the event took place when the Egyptian month Abib fell in the Spring. But the statement in Ex. ix. 31 and 32, seems to refer to some local peculiarity, that may designate the season within yet narrower limits. According to the Jewish mode of celebrating the Passover, the earliest date for the Exodus,

$$
\begin{aligned}
& \text { April } 12+\text { May } 31+\text { June } 30+\text { July } 19=92 \\
& \text { Abib } 16+\text { Misra } 30+\text { Epagomena } 5,=\frac{51}{41} \\
& 1460: 1539: \frac{4}{164}: 1413 \text { B. C. } 172_{319}^{3}, \\
& \text { may be placed at about B. C. } 1240 ;
\end{aligned}
$$

if, however, as modern Astronomers assert, the Rising of Sirius really recedes from the Equinox, this, perhaps, might place the Exodus some fifty years earlier. For the present, I shall only remark, that another element remains to be considered, before we can positively fix the date: Moses would naturally select the time of full-moon for a journey in the Desert, but the Egyptian month Abib is not a lunar month. That the Abib in question was the well-known Egyptian month bearing that name, appears from the establishment of Pentecost; celebrated for the first time, as will be seen above, on the last day of the Egyptian Year. 
divide the circle into 360 degrees $(=6 \times 6 \times 10$, or the square of $6 \times 10)$; and the quarter of the day into the same number of minutes: making $1440(=$ sq. $6 \times 40)$ minutes for the entire day.

The fractional quantity which would join the two ends of the cycle of time, has been given above, as $\frac{1}{4}^{d}-\frac{1_{7}}{77^{d}}=\frac{73}{3}^{d}{ }^{d}=341 \frac{23}{7}{ }^{\mathrm{m}}$. These minutes, when expressed as a whole number $(26,280$ seventy-sevenths $\mathrm{m}$.), are divisible only by 360 .

The Proportion of "113:355" is well known as an approximation to the ratio of the diameter to the circumference; and is commonly supposed to have been discovered by Archimedes. The first of these numbers proves to be the counterpart of the last employed fraction added to a quarter of a day, for $\frac{11 \mathrm{~d}}{4}+\frac{2 \frac{2}{6} \mathrm{~d}}{6 \frac{1}{6}}=410 \frac{10^{\mathrm{m}}}{1}=4520$ elevenths m. $=40 \times 113$.

Here, we again find the "sacred number" 40 ; and if we multiply together the squares of these two fractional quantities (sq. $3411_{77}^{2}{ }^{\mathrm{m}} \times \mathrm{sq}$. $410 \frac{10 \mathrm{~m}}{1}$ ), we shall include the square of 1440 , or of the number of minutes in a day.

On recurring to the Proportion which gives the irregularity in the revolutions of Jupiter's satellites, one of the portions of the quarter of a day $\left(\frac{1}{4}-19 \frac{517}{13} \frac{7}{7}=\right) 340 \frac{820 \mathrm{~m}}{1337}$, is found to be divisible by 360 ; and also by 11 ; while the complemental portion, if left unreduced $\left(19 \frac{517 \times 80 \mathrm{~m}}{1337 \times 80^{\circ}}\right)$ and expressed as a whole number, is itself the square of 1440 . On attempting to divide the square of 1440 by 11 , the remainder is found to be $\frac{1}{11}$; and it may also be remarked, that the sum of the two portions $(=360 \times 1337 \times 80)$ is divisible by 7 .

Multiplying this unreduced quarter by 1440 divided by the first member of the Proportion, gives $360 \times 1337 \times 80 \times 79 \frac{15}{19} \frac{7}{1}=3,073,593,600$ $=\mathrm{sq} .36 \times \mathrm{sq} .1540=\mathrm{sq} .24 \times \mathrm{sq} .2310$; and the same result is obtained from all fractions, not exceeding $\frac{1}{4}$, that can be expressed in minutes or 77 ths of a minute. The unconformable fractions require multiplying by the first denominator; thus,

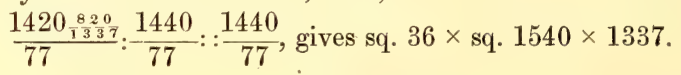

14. A standard measure of time should follow the properties of number: and it may already have been perceived, that $1 \frac{1}{2}$ Egyptian Great Years $(=2310=2 \times 3 \times 5 \times 7 \times 11)$ are composed of the indivisible elementary numbers multiplied together.

It now appears, that 2310 is a universal number; divisible by each of its component elements, and by every combination of two or more of 
them; the quotient in all instances consisting of the omitted elements. Further, on the introduction of a new quantity, multiplying the universal number by the same, will maintain these results.

In the following examples, the element 11 is left out of the calculation; as the remainder, $210(=2 \times 3 \times 5 \times 7)$, forms a quantity easily multiplied, and easily kept in mind :
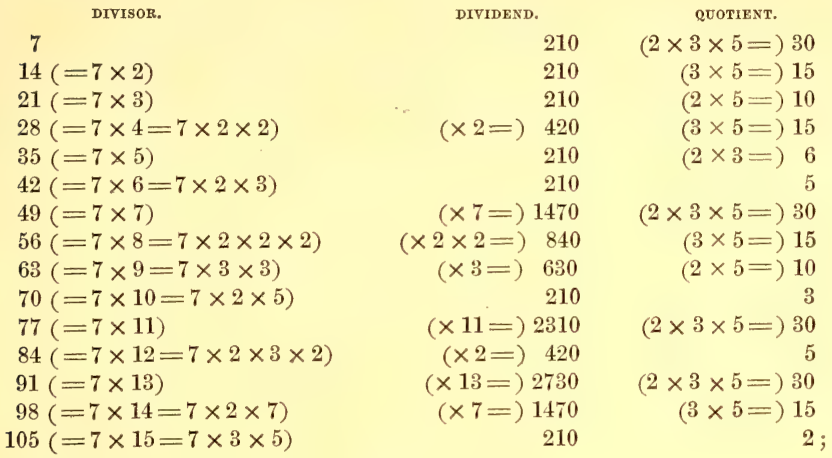

so, with the number 6 , and its multiples;
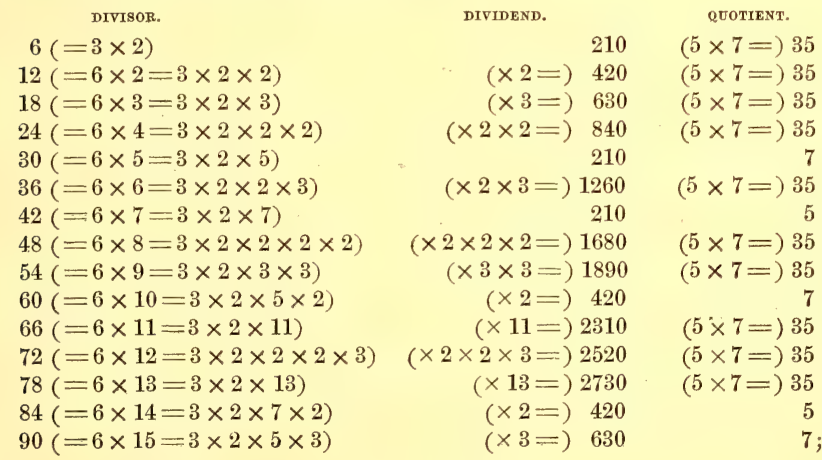

in like manner, we may go through the remainder of the Multiplication Table; and mentally supply divisible numbers, for quantities that at first appear inconveniently large. 
On further examining the properties of the indivisible elementary numbers, it may be remarked, that 2 and 5 can in a measure be concealed in 10 ; that 11 furnishes, as it were, two separate pivots for the change of elements (as $\frac{1}{11}+\frac{10}{1} \frac{0}{1}=\frac{4}{44}+\frac{70}{7}=1$ ); and that there remain in fact but two working elements, 3 and 7 ; the sum of which, is also 10 .

I do not know, how far the above analysis of numbers may have been previously noticed. The circumstance, that the Ancients rarely made use of "fractions," has been pointed out to me: and from what I witnessed among the people of Hindostan, I was led to suspect the practice there of arithmetical processes which are unknown to Europeans.

15. An Astronomical fact remains to be mentioned. In Greece, the atmosphere is so clear, that the stars are visible to the very edge of the horizon. When sailing among the Greek islands, I was much impressed with the spectacle presented by the constellation of the Great Bear, the lowest of the bright stars not quite reaching the surface of the ocean. It immediately occurred to me, that the same scene is described by Homer (see Il. xviii. 489, and Od. v. 275) : to the disproving of an assertion, repeated in works of high standing; that even at a later date than the days of Homer, The star we call the pole-star "was twelve degrees from the pole."

That the axis of the Earth has pointed to about the same place in the heavens ever since the days of Homer, is further proved from Posidonius; who gives a list of places along the shores of the Mediterranean, where on proceeding south the star Canopus first becomes visible (see his statement, as quoted by Cleomedes ii. 10, and by Strabo ii.). I do not know, whether any verification of these observations has been made in Modern times; but I am persuaded that if a change has taken place, it will prove to be extremely slight. 


\section{N D E X.}

\section{FOREIG N WORDS.}

Aatharilal, 121.

Abitheran, 115.

Abtykhym, אבטיחים, 14.

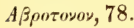

Abuscham, 38.

Acer gallicum, 95 .

Azepowts, 41.

Achilel melich, 43.

A'ds, 32 .

A'ds el-ma, 90

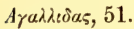

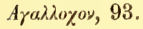

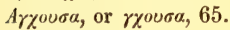

A

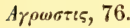

Agwz, 39.

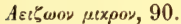

A بахฑ, 77.

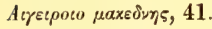

Atreเpos, 26.

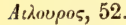

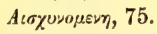

Ajes, or axes, (Aborig. Amer.), 135.

Axaxaㅊㄷ, 92.

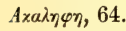

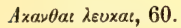

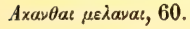

Ax $\alpha \nu \eta \eta, 60$.

Axaע $005,81$.

Aхоуยтоข, 70.

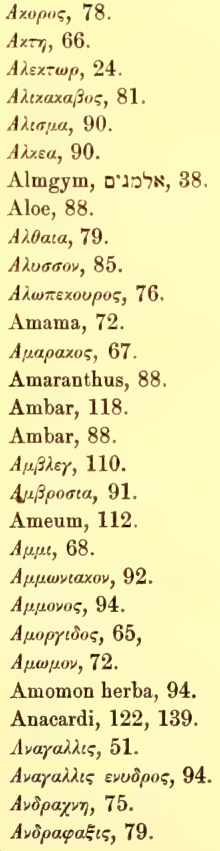




\section{N D E X}

Aขะนочортоу, 90.

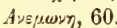

Anjurat, 120

Anthriscum, 62.

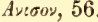

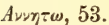

Apium, 58.

$A \psi v \nu \theta \omega, 54$.

Argemonia, 89.

A

Arjan, or arjuna (Mahratta), 121.

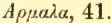

A $\rho \nu \alpha \beta \omega, 96$.

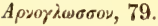

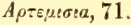

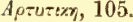

Aбаре凶, 82.

Askútasquash (Aborig. Amer.), 142.

Askyl, 55.

$A \sigma \pi \alpha \lambda \alpha \xi, 80$.

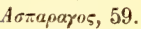

Asparagus, 59.

Aбтреоч, 94.

Athl, 114.

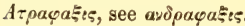

Atrum olus, 72.

Axes, or ajes, (Aborig. Amer.), 135.

Axies (Aborig. Amer.), 135.

Ayakbouh, 46.

Azwb, אוז 34.

Bachra, 69.

Bachur, 55.

Badingan, 112.

Bahman, 116.

Bakar, 154

Bakla, 76 .

Baх $\alpha \rho: 5,55$.

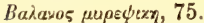

Bale, or ball (Bengali), 116.

Baike, 37.

Ball, or bale (Bengali), 116.

Bamiat, 115.

Batatas (Aborig. Amer.), 134.

Bazos, 45.

Baтрахєоу, 70.

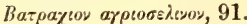

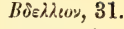

Bdlkh, ברלח, 31.

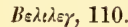

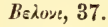

Bernice arbor, 127.

Bersym, 76.

Besilleh, 64 .

Bisch, 70.

Bkr, בכר, 154.

$B \lambda \eta \tau o \nu, 64$.

B之етоу, 64.

Boגßos, 64

Booza, 19.

Botm, 34.

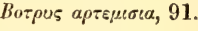

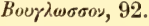

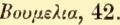

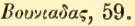

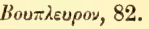

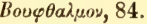

$\mathrm{Br}, 72,33$.

Bras (Malay), 74.

B роноร, 71.

Bryt, ברית, 53.

Bshm, בשם בפרית, 38.

Btnym, כטנים, 34.

Btzlym, בצלים, 12.

Buglossa, 119.

Bul, or bwl, בול, 165.

Burr, 34.

Cafur, or kafur (Bengali), 109.

Calamus Alexandrinus, 75.

Carafs, 45.

Carduus nondum fullonibus aptus, 93.

Chænopadas, 85.

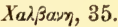

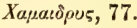

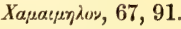

Xар.а. $\pi เ \tau u s, 82$.

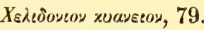

Chichorium, 57.

Chortinon, 94.

Chouk, 37.

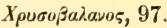

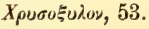

Cicutæ, 119. 


\section{FOREIGN WORDS}

Cimex, 63.

Cimini carmeni, 120.

Convolvulus, 95.

Coriandrum, 69.

Corrago, 92.

Cotula, 130

Croton, 61.

Cyanus, 94.

$\triangle$ avะos.

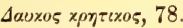

$\triangle \alpha \varphi \nu \eta, 44$.

$\triangle \alpha \varphi \nu \eta$ a $\lambda \varepsilon \xi \alpha \nu \delta \rho \varepsilon \iota \alpha$.

Dbywnym, רביונים, 46.

Dend, 113

Deyl el-far, 118.

Dgn, , רา, 33.

Dianthi, 129.

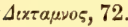

Dima ayoub, 106.

$\triangle$ เ४ахоร, 93.

Diwdar (Bengali,) 120

Dkhn, רחי, 33.

Dokhn, 22, 33.

$\Delta o$ icxos, 69 .

Dourra, 98.

Draconis saniem, 66 .

Dracunculus, 71.

Dragontea, 112

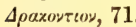

Drdr, רררר, 32.

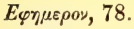

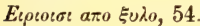

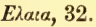

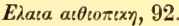

Eגatopsht, 42.

Eגачоßобхоу, 93.

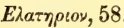

$H \lambda \in \times \tau \rho o \nu, 46$.

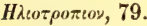

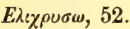

$E \lambda \lambda_{\varepsilon} \beta о \rho о 5,65$

Elul, or alwl, אלול, 165.

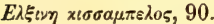

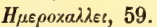

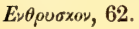

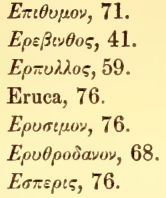

Fabula, 37.

Фахоร $0 \varepsilon \pi t \tau \varepsilon \lambda \mu \alpha \tau \omega \nu, 90$.

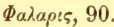

Far, 34, 42.

Фa.ॅ소, 64.

Faselum vilem, 64.

Фаббохортоу, 83.

Faurum, 42.

Fawfal (Mahratta), 109.

Fel, 116.

$\Phi \varepsilon \lambda \lambda \circ \varsigma, 58$.

Festok, 75.

$\Phi_{\text {เ } \lambda \lambda u \rho \varepsilon \alpha,} 92$.

$\Phi$ iरे $\rho \alpha, 63$,

$\Phi \lambda$ oytov, 60 .

$\Phi$ 入орно5, 63

Flos siriacus i flos malvæ, 127.

$\Phi_{\text {otv }} \xi, 91$.

Fool, 37.

$\Phi_{0 \nu}, 57$.

Фova, 68.

Frasioun, 77.

Fujl, 111.

Фuxos, 54.

$\Phi u \lambda_{\imath x \eta}, 80$.

Galia muscata, 122.

Garna, 79.

Garyophyllon, 94.

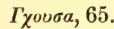

Gelisia, 95 .

Gentiana, 84.

Tepavtov, 79.

$\Gamma_{\eta} \theta u \lambda_{\iota} \delta \alpha \varsigma, 56$.

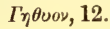




\section{N D E X.}

Ghobbeyreh, 61 .

Gios, 39.

Glastum, 87.

$\Gamma \lambda \eta \chi \omega \nu, 51$.

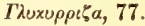

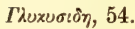

Gml, נמל, 75.

Forrukes, 55, 64.

Goomad el-owwal, or goomada-l-oola, 165.

Goomad et-tanee, or goomada-t-taniyeh, 165

Gramen Arabum, 75.

Grana paradisi, 124.

Gromphæna, 95.

Gutran, 43.

Gutteh, 14.

Habhasis, 79 .

Hadak, 39.

Haledj, 143.

Hamdhidh, 115.

Hares, 116.

Harmal, 41.

Hbni (hieroglyph.), 19.

Helbeh, 43.

Hemsis, 39.

Herba Britannica, 95.

Herba impia, 94.

Herbe Sancte Marie, 91.

Hommos, 41.

Hordeum murinum, 91.

Horræjg, 92.

Horreyg, 92.

Hour, 41.

Hunesdarm, 123.

Hyssopum, 119.

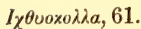

Iqvov, 40, 57.

Indicum, 50.

Indicum nigrum, 88.

Intubum erraticum, 57 .

Iov, 46.

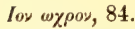

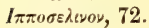

I

I $\rho เ \varsigma, 67$.

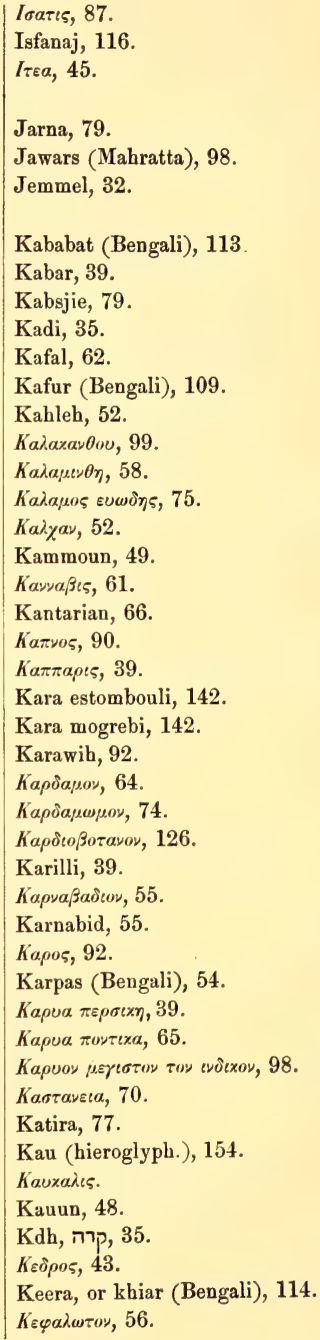




\section{FOREIGN WORDS.}

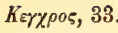

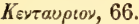

$K \varepsilon \rho \alpha \sigma o 5,80$.

Ke $\alpha \tau \imath \iota \alpha, 80$.

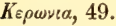

Keschut, 38.

Khafur, 124.

Kharub, 49.

Khawlanjan, 112.

Khdk, חר, 39.

Khiar, or keera (Bengali), 114.

Khiar janbar, 103.

Khlbnh, חלבנה, 35.

Khrwl, חרול, 39

Khth, הטח, 14.

Khwkh, חוח, 37.

Kเxts, 80.

Kเxua, 48

Kilkil, or kolkol, 109.

Keva $\rho \alpha, 14$.

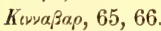

$K(\nu) \alpha \mu \omega \mu \nu \nu, 35$.

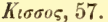

Kєт

$K \lambda \gamma_{1} \theta \rho \eta, 44$.

Kmkb, קכ, 10.

Kmn, כמן, 49.

Knmwn, קנמון (Tamil), 35.

Kohl, 23.

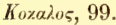

Кохко $\mu \eta_{1} \lambda \nu, 55$

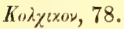

Kolgas, 85 .

Kolkol, or kilkil, 92.

Ko) $0 \times \alpha \sigma \iota \alpha, 85$.

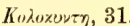

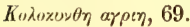

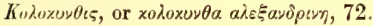

Kopapos, 81.

$K \omega \nu \varepsilon เ \omega \nu, 37$.

Kผข้ๆ, 56.

Kореаууоу, 69

Kıрเs, 63.

Кюрюуоточร, 79

Koroumb, 55.

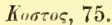

Kัยขอยส
Kourat, 57.

Kpr, בפר, 39.

$K \rho \alpha \mu \beta \eta, 55$.

Ko $\alpha \nu \varepsilon \imath, 44$.

$K \rho t$, and $x \rho t \theta \eta, 13$

Krkm, כרכם, 39

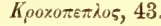

Kоохог, 25.

Коонциа, 12.

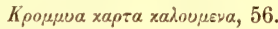

$K \rho \circ \tau \omega \nu, 61$

Krps, כרפס, 54.

Krt, כרת, 57.

Ktzyowt, כציתית, 38.

Kuajes, 41.

Kореуоу, 49.

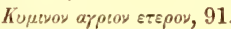

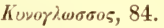

Kерониเа, 34.

Китарьббоร, 44.

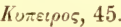

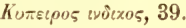

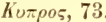

Kurcum, 39.

Kurras, 120.

Kurth, 94.

Kus, 32.

Kykywn, קיקיון, 48.

Kymwsh, and kmsn, קימוש, and

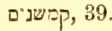

Kwtz, rpp, 32.

Ladanum, 62.

Laden, 62.

Lak, 116.

$\Lambda \alpha \pi \alpha \theta_{o \nu}, 57$.

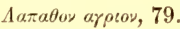

Aa.tupos, 69.

Lbnb, לבנה, 23, 33.

Lebakh, 115.

Lebakh el-gebel, 99.

Lebleb, 113.

Lectuli bestias, 63 .

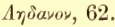

Lehibakb, 100.

Asıрtov, 45.

$\Lambda \varepsilon \pi \iota \hat{\imath} เ \nu$, 91. 
I N D E X.

$\Lambda \varepsilon v \times \eta, 41$.

Asuxoเov, 76.

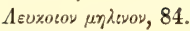

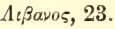

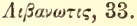

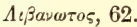

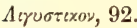

Lilium, 45.

Limun (Bengali), 117.

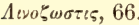

Lissan el-hamal, 79.

Lissan el-tour, 92.

Aoßos, 69.

Lonh, לענה, 37.

$\Lambda \omega \tau \circ \varsigma, 22,43,80$.

Louz, 33.

Luban, 23.

Lubanum, 33.

Lubia, 69 .

Lubia frandji, 138.

Luffah, 124.

Auros, 43 .

Аบхเоу, 89.

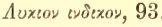

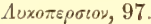

Lutum, 87.

Lwz, לו 33.

Lycium, 88.

Maxe $\rho, 93$.

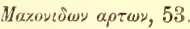

Malabrathrum, 83.

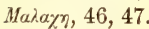

Malum, 42.

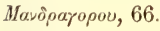

Manga, 139.

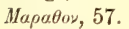

Mardakusj, 67.

Mapov, 92.

Maseh, 47.

$M a \% \alpha, 47$.

$M y_{\gamma} \delta t \times \eta, 28$.

Mryxw pota.5, 37.

$M \varepsilon \lambda \alpha \nu \theta t o \nu, 53$.

$M \varepsilon \lambda \varepsilon \alpha \gamma \rho t \varsigma, 72$.

Melh afsantin, 54

$M \varepsilon \lambda \iota a, 42$.

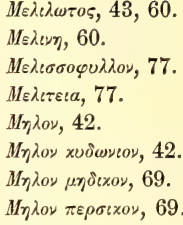

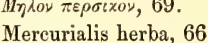

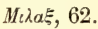

Milæh, 60 .

Millefolium, 112.

$M \iota \nu \theta \eta, 55$.

Mish, 81

Mlwkh, מלוח, 50.

Mwiv, 41.

Mopov, 29.

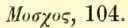

Mr, מור מר, מרים 34.

Mrrym, מרר' 34.

Muเa, 39.

Mucìuขea, 88.

Mullæah, 50.

Mulukhia, 116.

Mur, 35.

Muralis herba, 77.

Murreyr, 34.

Mus, 49.

Muscæ spicula, 34.

Najm, 124.

Naphri, 103.

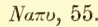

Naranj (Bengali), 117.

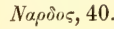

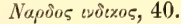

Na.jō $x \varepsilon \lambda \tau \iota x \eta, 57$.

Narjis, 47.

Nop $\% є \sigma \sigma \circ 5,47$.

Nasturtium, 86.

Nefyr, 103.

$N \varepsilon \pi \varepsilon \nu \theta \varepsilon \varsigma, 43$.

Nepeta, 112.

Neschusch, 49.

Ngau (Chinese), 154.

Notzwtz, קוצנ, 49.

Nrd, נרד, 40. 
FOREIGN WORDS.

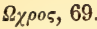

Odsh, ערש, 32.

Sxเuov, 67.

0 ivo $\alpha, 42$.

Olus atrum, 72 .

$0 \pi \circ \pi \alpha \nu \alpha \xi, 78$.

$0 \pi \circ 5 \mu \eta \delta$ ¿xos, 73.

Orb, ערב, 49.

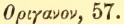

$0 \rho \nu t \theta o \varsigma$ $\gamma \alpha \lambda \alpha, 46$.

0 oоßоร, 70.

$0 \rho v \zeta a$ (Malay), 73.

Oschar, 33.

$0 \xi \alpha \lambda t s, 84$.

$0 \xi \cup \alpha, 80$.

$0 \xi \cup \alpha \times a \nu \theta \alpha, 79$.

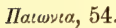

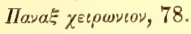

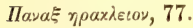

Papas (Aborig. Amer.), 138

Па $\rho \varepsilon \varepsilon เ \circ \nu, 77$.

IIrravov, 64.

$\prod_{\varepsilon \nu \tau \alpha \varphi v \lambda \lambda \alpha_{0}} \rho \iota \zeta \omega \nu, 66$.

Pentaphyllum, 66.

$\Pi_{\varepsilon \pi \varepsilon \rho \iota}$ (Malay), 68.

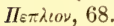

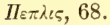

$\Pi_{\varepsilon} \pi \lambda_{\circ \varsigma}, 90$.

$\Pi_{\varepsilon, \rho \delta} \operatorname{exco\nu ,~} 77$.

$\prod_{\varepsilon \rho \iota \pi \lambda o x \alpha \delta \alpha,} 128$.

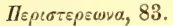

$\Pi_{\varepsilon \rho \sigma \varepsilon \alpha, 24 .}$

İe $\sigma: \times \alpha, 81$.

Petalion, 83.

Petroselinum, 89.

$\Pi_{\ell} \sigma \varepsilon \lambda_{\ell}, 64$.

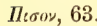

Pistacia, 75.

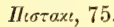

IItนร, 44.

$\Pi \lambda \lambda \alpha \tau \alpha \nu t \sigma \tau{ }^{\prime}, 45$.

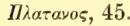

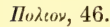

Похеуоуоу, 84.

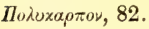

Porrum sectivum, 57.

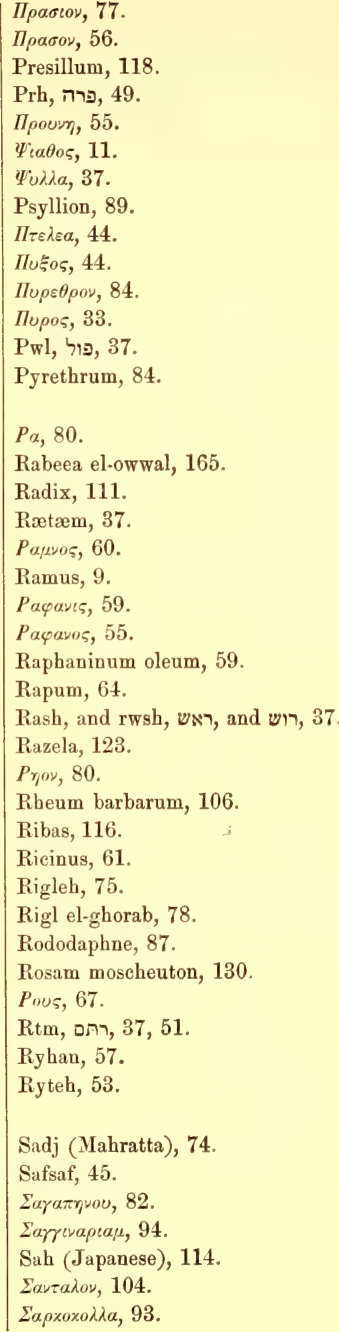


I N D E X.

$\Sigma \alpha \sigma \alpha \mu \omega, 52$.

Secale, 42.

Seigle, 42.

¿etova $\lambda, 165$.

Selem, 18.

Selica seuda, 93 .

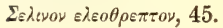

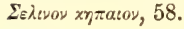

Selk, 23.

Semsem, 52.

$\Sigma \eta \mu \nu \delta \alpha, 80$.

$\Sigma \varepsilon \rho เ \delta े \alpha, 57$.

$\Sigma \eta \rho\llcorner x \alpha, 73$.

$\Sigma \varepsilon \sigma \varepsilon \lambda \ell, 69$.

Setargi indi, 120.

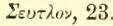

Schea, 32.

$\Sigma_{\chi ะ \nu 05,62 .}$

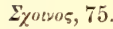

Sena, 34, 107.

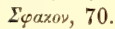

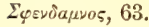

Shorh, שערה, 13.

Showwal, 165.

Shwshn, שושי 29.

Shyeh, 32.

Shykh, שיח, 32.

Sibistan, 113.

$\Sigma_{\text {¿xua }, 48 .}$

$\Sigma_{\text {txuos, }} 48$.

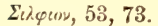

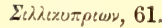

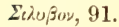

Sinapi, 55.

Sisaban, 123.

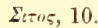

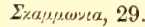

$\Sigma_{x \alpha \nu \delta t \xi}, 64$.

$\Sigma_{x \iota \lambda \lambda a, 55 .}$

Exokupos, 47.

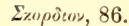

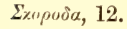

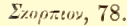

$\Sigma_{\varkappa \nu \theta เ \times \eta} \rho t \zeta \alpha, 77$.

$\Sigma_{\mu \nu \rho \nu \alpha,} 35$.

Suh, סנר, 34.

इoryos, 69 .
Sphæri, 76.

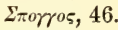

Squash, see Askútasquash.

Sschin (hieroglyph.), 29.

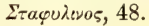

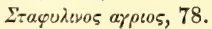

$\Sigma \tau \rho \cup \chi \nu \circ \varsigma, 76$.

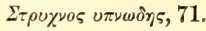

$\Sigma \tau \rho \cup \theta t o v \rho \iota \zeta \eta 5,70$.

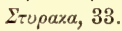

Succinum indicum, 88 .

Sufar, 165.

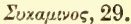

Susann, 29.

Tamalak, or tumluk (Dongola), 125.

Tamul, 109.

Tanarita, 112.

Tanbul (Mahratta), 109.

Tartir, 32.

Tat (hieroglyph.), 29.

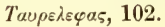

Taupos, 154.

Teil, 118.

$T \varepsilon \rho \varepsilon \beta \iota \nu \theta 05,34$.

Termes, 41.

Testudinum dorsa, 73 .

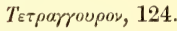

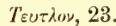

Thalisfar, 113.

Өa $\psi \omega, 53$.

Tharkhun, 112.

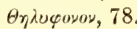

$\theta \lambda \alpha \sigma \pi \imath, 70$.

Thour, 154.

$\theta \rho \iota \delta \alpha \times a, 52$.

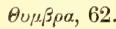

Oupov, 65.

Өvov, 43.

Thwr, תור, 154.

Tiffah, 39.

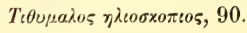

Toupxot, 105.

Tpwkh, חפת, 39.

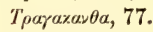

Tрауотшбоу, 80.

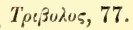




\section{FOREIGN WORDS.}

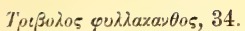

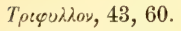

Tumluk, or tamalak (Dongola), 125.

Turea virga, 62.

Tut, 29.

Twkyym, תוכ"ים (Tamil), 38.

Tzptzph, צפצים 45.

Tzry, צרי 33.

$r_{\alpha \times \iota \nu \theta 05}, 46$.

Uard, 40.

Yosaprupos, 66

Ukhowan, 126.

roбะvано, 67.

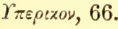

$\Upsilon_{\sigma \sigma \omega \pi 05,} 34$.

Vacca, 154.

Vache, 154.

Vars, 116.

Venich, 123.
Verbena, 83.

Vettonica herba, 87.

Virga aurea, 127.

$\Xi_{\alpha \nu \theta t o \nu,} 91$.

$\Xi \alpha \nu \theta o \beta a \lambda a \nu o s, 97$.

Yansoun, 56.

Yasmin, 114, 120.

Zakkoum, 107.

Zarnab, 96.

Zatar hendi, 120.

$Z s a, 42$.

Zeytoon, 32.

Zif, or zyw, ri, 165.

Zingiber, 88.

Zizyphus, 89

Zubbad, 122

Zymbane (Negro), 88

Zyt, תז, 32. 



\section{N D E X.}

\section{NAMES OF PERSONS.}

A.

Aahmes, 21.

Aahmes II., or Amasis, 54.

Abd Allatif, 18, 115, 117.

Abd-el-Hamid, 151.

Abd-el-Medjid, 153.

Abd-el-Melek, 109, 110.

Abix, 107.

Abram, 113.

Abubekr, 127.

Abu Hanifa, 94, 98, 104, 109, 112, 115.

Abu'l Abbas, 111.

Abulfadli, 118.

Abul-Fawaris, 119.

Abulfeda, 50, 114, 118.

Abuzeid, 98, 114.

Achæus, 47, 55.

Achmed, or Achmet, 145.

Achmed II., 148.

Achmed III., 149.

Achmed Abu-l-Fetah, 130.

Achoris, see Hakor.

Acosta, 139.

Actuarius, 94, 97, 103, 111.

Adams, F., 82, 97, 107, 111, 113, 114, 117, 118, 124.

Adanson, 143.

Adelard, 111.

Adhed, 122.

Adrianus, see Hadrianus.

Aegineta, Paulus, 42, 54, 62, 66, 67, 68, $70,71,79,82,87,88,90,92,93$ to 96 . Flfiic, 121.

Aelius Promotus, 70.
Aemilianus, 99.

Aeneas Tacticus, 48.

Aeschylus, 11, 24, 29, 55, 58 .

Aeschylus, the Archon, 48, 49.

Aetius, 88, 93, 96, 104.

Africanus, Julius, 36, 40, 48, 49, 51, 159.

Agatharchides Cnidius, 63.

Agathias, 105.

A hmed El-Mozaffer, 129.

Ahrun, 107.

Ainslie, 83, 109.

Aiton, 146, 148, 151.

Ajax, 46

Albasari, 107.

Alcæus, 48, 53.

Aleman, 52, 53 .

Aldinus, Tobias, 145.

Aldrovandus, 140.

Alexander I., 58.

Alexander III., 21, 58, 72, 74.

Alexander IV., 74.

Alexander Myndius, 58.

Alexander Severus, see Severus.

Alexander Trallianus, 105.

Alexis, 69, 70.

Ali, 108, 109.

Ali-Bey, 151.

Ali El-Mansur, 128.

Alkanzi, 113.

Allatafet, 102, 117.

Alpinus, 12 to 145 .

Alsted, J. H., 50, 101, 104, 127.

Alvarez, 117.

Amasis, see Aabmes.

Amatus Lusitanus, 124, 139 
$1 \mathrm{~N} \mathrm{D} \mathrm{E} \mathrm{X.}$

Ameipsias, 59.

Aristobulus, 73

Amenatep, Aminadab, or Amenophis, $22 . \quad$ Ariston, 65.

Amenatep II., 25.

Amenatep III., 26

Amenatep IV., 26.

Amenemha, or Ammeneme, 16.

Amenemba II., 16

Amenemha III., or Amenemba Moeris, 19.

Amenemha IV., 19.

Aristophanes, 11 to 65 .

Aristophon, 39, 64, 70.

Aristoteles, 17 to 72 .

Arnaldus, 127.

Arrianus, 58, 73.

Arses, 72.

Artabanus, 60.

Amenophis, see Amenatep.

Artaxerxes, see Artcheschsesch.

Ammeris, see Amnerith.

Amnerith, 50.

Amos, 25, 33, 37.

Amphis, 29, 59.

Amphitryon, 36.

Amru, 107, 108, 121.

Amurath, see Murad.

Amyrtæus, see Meritetnacht.

Ananias, 55 .

Anastasius, 104.

Anatolius Berytius, 99 .

Anaxandrides, 69.

Anaxilaus, 38.

Andrews, 132.

Andromachus, 57, 72, 82, 83.

Ange de Saint-Joseph, 33.

Anguillara, 80, 138, 140, 141.

Annaniah, or Annianus, 93.

Antigonus of Carystus, 70, 72.

Antiphanes, 29, 59, 63, 68, 69.

Antoninus, Mareus Aurelius, 97.

Artcheschsesch, or Artaxerxes, 60.

Artcheschsesch III., or Artaxerxes Ochus, 70 .

Asa, 41.

Assa, 13.

Asclepiades, 68.

Atai, or Othoes, 14.

Athenæus, 14 to 82 .

Athothis, and Thoth, 4, 5, 6 .

Augustus, 87.

Aurelianus, 100

Aurelius Claudius, see Claudius.

Aurelius, M., see Antoninus.

Averrhoes, 106.

Avicenna, 18, 32, 47, 61, 77, 78, 81, 82, $92,94,96,98,100,104,106$ to 120 .

Azariah, see Uzziah.

Aziz, 120.

B.

Antoninus Pius, 97, 159.

Antonius, 85.

Antonius, M., 87.

Apicius, 92.

Apion, 159.

Apollodorus, 75, 82.

Apollodorus Carystius, 55

Apollonius Tyaneus, 98.

Apries, see Hophra.

Apuleius, 87, 121.

Apuleius Barbarus, 72, 78, 92

Arcadius, 103.

Archelaus, 88.

Archestratus, 57, 64 .

Archimedes, 166.

Aretæus, 64, 69, 93, 99

Bachman, J., 139.

Bacon, Roger, 126.

Bakui, 114, 118.

Balbillus, 89 .

Balbinus, 140.

Barcia, 138, 139, 143.

Barakah-Khan, 126.

Barkook, 128.

Barrelier, 133, 138.

Barsebay El-Aschraf, 129.

Barthema, see Vertoman.

Bartram, J., 139.

Baudet, 119.

Bauhin, C., 62, 132, 133, 134, 137 to 144.

Beale, 118. 


\section{NAMES OF PERSONS.}

Beckmann, 35, 64, 98, 111, 123, 137, 140, Caracalla, 98.

144, 146.

Belbay, 130 .

Belon, P., 34, 38, 41, 42, 44, 53, 57, 59, $70,75,78,80,89,91,103$ to 139 .

Belzoni, 28.

Ben Masah, Isa, see Ibn Masah.

Benzoni, Hieronymus, 140.

Besler, B., 46, 138, 145.

Beydarah, 127.

Biot, 155.

Birch, S., 6 to $52,68,102$.

Blake, J., 151.

Boccone, 128, 147.

Bonaparte, 152.

Bonomi, J., 14.

Bontius, J., 74, 75, 93, 110, 116, 117, $124,144,146$.

Bory de St. Vincent, 12 to 141.

Brancion, 142.

Breynius, J., 149.

Browne, 72, 122, 130, 143.

Brunfels, O., 112, 126, 130, 137.

Bruyerinus, John, 137.

Bung, 140.

Bunsen, 154, 158, 159.

Busbecke, 140.

Buxbaum, J. C., 150.

Çarate, 138.

Carinus, 101.

Carus, 100.

Castor Durantes, 141.

Catesby, M., 149, 150.

Cato, 29, 31, 39, 58, 59, 64, 66, 67, 83 .

Catullus, 63.

Cavallini, 146.

Cavanilles, 148, 150, 152.

Celsus, $35,40,61,66,75,77,78$ to 89 .

Censorinus, 161, 163.

Cephisodorus, 55, 67.

Chæremon, 67.

Champollion, 5 to 162.

Champollion-Figeac, 5 to 162 .

Chariton, 110.

Charlemagne, 102, 111, 112

Charles Martel, 111.

Chaubard, 43, 141, 147

Cheops, see Chufu.

Chephren, see Schafra.

Cheschearscha, or Xerxes, 58, 108.

Cheschearscha, II., 63.

Christophorus de Honestis, 122.

Chufu, or Cheops, 11.

Cicero, 45.

Cieca, Petrus, 138.

Claudius, 89.

Claudius II., or Aurelius Claudius, 100

Claudius Iolaus, see Iolaus.

Cadamosto, 117, 122, 129.

Clearchus Solensis, 39.

Cadmus, 35, 36

Clemens Alexandrinus, 4, 5 .

Cæsalpinus, A., 142, 143.

Cæsar, 32, 87.

Clemens Romanus, 96.

Cleomedes, 168.

Cleopatra, 87.

Cleophantus, 48.

Caius, see Caligula.

Calamis, 58.

Cleyer, 147.

Caligula, Caius, 89 .

Callimachus, 36, 48, 51 .

Callinicus, 109.

Callisthenes, 17.

Callixenus, 43, 44, 62, 63, 72, 76, 81 .

Cambyses, see Kembath.

Clinton, 17 to 164 .

Clot-Bey, 28 to 153 .

Clovis, 106.

Clusius, 92, 133, 137, 138, 140 to 145

Clytus of Miletus, 72 .

Colarbas, 97.

Camerarius, J., 61, 76, 123, 127, 133, 138, Columbus, 134, 135.

139, 140, 143.

Capella, Michael de, 118.

Columella, $62,64,72,75,76,81,85$ to 89. 


\section{N D E X}

Columna, Fabius, 59, 145.

Commelyn, J., 149.

Commodus, 97.

Constantinus, 66.

Constantinus, 101, 102.

Constantius, 101.

Constantius II., 102.

Cook, 151.

Cordus, Valerius, 91, 122, 135, 138.

Cornelius, see Lentulus.

Cornuti, 145, 146.

Cortusi, 141.

Cosmas Indicopleustes, 82, 98, 104.

Costus, 111.

Crassus, P. Licinius, 160 .

Crates, 52.

Cratevas, 83.

Cratinus, 48, 52, 59, 60 .

Ctesias, 17, 33, 65, 68.

Curtius, Quintus, 42, 73.

\section{D.}

Daher, 120.

Dalechamp, J., 76, 112, 127, 133, 136, 138, 142.

Damogeron, 75, 102.

Danaus, see Ramses III.

Darius, see Nteriusch.

David, 37.

Decius, 99

De la Vega, Garcilasso, 138

Del Barco, Martinus, 139, 143.

Delile, 13 to 152 .

Della Cella, P., 53 .

Demochares, 62 .

Democritus, 99

Demosthenes, 57, 65, 66, 70 .

De Rougé, 14, 22, 27.

De Soto, 138.

De Sousa, Jao, 55, 124.

Desvergers, 124, 126, 128.

Dhafer, 122.

Dhanvantare, 117.

Diagoras, 43.

Didius Julianus, 97.

Didymus, 67.
Dieuches, 48.

Dillenius, J. J., 64, 144, 150.

Diocles, $48,57,58,64,67,79,81$.

Diocletianus, 101.

Diodorus, 4, 42, 63, 67, 86 .

Diodotus, Petronius, 78.

Diomedes, 45.

Dionysius Exiguus, 104.

Dionysius Periegetes, 75.

Dioscorides, 23 to 94 .

Diphilus, 54, 56, 80, 81.

Djakmak, see Jakmak, 129.

Djauhar Kaid, see Jauhar.

Djemaleddin Yusuf, see Jemaleddin

Djenghiz-Khan, see Jenghiz-Khan.

Dodonæus, R., 22, 82, 91, 106, 123, 130, $132,134,137,138,140$ to 142 .

Dombey, 151.

Domitianus, 96.

Domitianus, L. D., 100.

D'Rosario, 55.

D'Urville, 150

E.

Edrisi, 74, 110, 114, 116, 117, 118 to 122 .

Elagabalus, 73, 98 .

El-Amin, 112.

El-Amr, 121, 122.

Elgafaki, 114.

El-Hadi, 111

El-Hafez, 122.

Elhuri, 113.

Elijah, 37.

Ellababali, A. H., 115.

El-Mahadi, 111.

El-Mamun, 112, 113.

El-Mansur, 111.

Elnabati, A. A., 103, 115.

Eltamini, 102, 118.

Elthabari, 111.

Elzaharawi, 121.

Ennius, 83.

Epænetus, 56, 63, 82.

Epicharmus, 24, 39, 40, 52, 55, 56, 57.

Epilycus, 55. 


\section{NAMES OF PERSONS.}

Eratosthenes, 36 .

Erasistratus, 43.

Eriphus, 69.

Esther, 54.

Eubulus, 29, 56, 59, 67, 68 .

Euclides, 7.

Eudemus, 23.

Euphorion, 60, 70.

Eupolis, 38, 59, 60, 63 .

Euripides, 23, 62.

Euryphon, 60, 65, 66, 67 .

Eusebius, 35, 48, 49, 50, 93.

Eutyches, 104.

Evenor, 81.

Ezekiel, 32, 33, 35, 37, 45.

\section{F.}

Fabius Pictor, 160.

Faradj, 128.

Fatimah, 119

Fayez, 122.

Fee, 87 .

Fenestella, 32 .

Feuillee, L., 150.

Figari, 28 to 153 .

Fisher, T., 156.

Flaceus, Publius Avilius, 89.

Florentinus, 48, 55 .

Florianus, 100.

Forskal, 13 to 151.

Forster, 151.

Fracastor, Hieronymus, 134.

Franciscus Pedemontium, 91, 122, 124

Fuchsius, L., 94, 122, 123, 126, 130, 131, 134, 135, 137, 138.

Fulton, 152.

G.

Galba, 93 .

Galen, 41, 48, 51, 56, 59, 61, 66, 68, 69, $70,71,73,77,78,79$ to 82,87 to 97 .

Galerius, 101.

Gallienus, 99.

Gallus, Cornelius, 87.

Gallus, Trebonianus, 99.

Garcias, 40, 139.

Garetus, 144.
Gaza, Theodorus, 58.

Gentius, 84.

Gerarde, J., 70, 123, 127, 134, 138, 144.

Germanicus, 30.

Gesner, C., 132, 134, 137, 138, 140, 141.

Gesenius, 29, 39, 49, 67, 100.

Geta, 98 .

Gibson, 121, 144.

Gittard, 87, 92, 141.

Glaucias, 85 .

Glaucon, 82.

Gliddon, 4, 30, 38, 45, 46, 67, 153, 155.

Gomara, Lopez de, 134, 135, 138, 139.

Gonsalvo Ferrand, 136.

Gordianus Pius, 99.

Graham, J., 39, 53, 74, 95, 96, 100, 107, $110,115,116,121,125,130$ to 153.

Granger, 59, 133.

Gratianus, 102, 103.

Greenhill, W. A., 82, 116.

H.

Hadji Saleh, 128.

Hadrianus, or Adrian, 96, 160.

Hakem, 120.

Hakor, or Achoris, 67.

Hales, 36.

Haller, 96, 113, 132.

Haly Abbas, 32, 98, 103, 107, 109, 113, $117,118$.

Harpocration, 60.

Harris, A. C., 72.

Harris, T. W., 138, 142.

Harun-el-Rashid, 111.

Hassan, 127.

Hasselquist, 12 to 145.

Hawkins, 67, 77, 92.

Hecatæus, 56.

Hegesander, 29, 65, 69.

Helena, Flavia Julia, 101.

Heliodorus, 98.

Hellanicus, 60.

Her, or Horus, 26.

Heracleon of Ephesus, 70.

Heraclides Tarentinus, 64.

Heraclius, 106, 107.

Herapath, 50 . 


\section{N D E X.}

Heresbach, Conrade, 137.

Hercules, 36.

Hermann, P., 147, 148, 149.

Hermas, 34.

Hermes, or Ermes, see Ramses II.

Hermolaus Barbarus, 130.

Hernandez, 145.

Herodotus, 5 to $62,108$.

Heron, 84.

Hersehel, 156.

Hescham, 110.

Hesiodus, 29, 36, 41, 42, 44, 46, 47, 52 .

Hezekiah, 50 .

Hicesius, 76 .

Hieronymus, 38, 100.

Hildegard, 95, 123

Hippocrates, 58, 68, 69 .

Hipponax, 52, 55.

Hobaisch, 109, 113, 114.

Hoisington, 38.

Homerus, 5 to $46,51,52,168$.

Honain, 104, 111, 113.

Honorius, 103.

Hophra, Uaphres, or Apries, 54.

Horapollo, 56, 60 .

Horatius, 74, 78, 83.

Horus, see Her.

Hosea, 29, 32, 33, 37, 39.

Hoskins, 89.

Hulagu Khan, 126.

Humboldt, 135.

Hyacinthus Ambrosinius, 145.

Hyginus, 46.

Hyperides, 72.

\section{I.}

Iambulus, 86 .

Ibek, 125.

Ibn Amran, Isaac, 107, 109, 112, 113, 114.

Ibn Baitar, 35, 77, 82, 94, 98, 103, 106, 109 to 125.

Ibn Elhozar, 116.

Ibn Gnefith, 103.

Ibn Jamia, 117.

Ibn Joljol, 120.

Ibn Masah, 98, 114.
Ibn Masawia, 103, 104, 107, 111, 112, 113.

Ibn Redwhan, 94, 121.

Ibn Samhun, 116.

Ibrahim, 146.

Ibrahim, 111.

Ibyeus, 44, 52 .

Idatius, 101.

Ignatius, 96.

Ikhsehid, 118, 119.

Imperatus, Ferrandus, 144, 145.

Iolaus, Claudius, 85 .

Ion, $23,55,57$.

Iphigeneia, 36 .

Iphitus, 36, 48.

Isaiah, 17 to 50 .

Isidorus Hispalensis, 72, 93, 106.

Ismael, 122.

Ismael-Bey, 150.

\section{J.}

Jacobus of Edessa, 104.

Jakmak, or Djakmak, 129.

Jauhar Kaid, 119.

Jemaleddin Yusuf, 129.

Jenghiz-Khan, 124.

Jephthah, 36.

Jeremiah, 23, 32, 33, 37, 53, 54 .

Jerome, see Hieronymus.

Joannes de Sancto Amando, 91.

Joannes Epiphaniensis, 105.

Job, 29, 32, 37, 39, 49, 50, 51.

Joel, 33, 39.

Johnson, T., 134, 146.

Jonah, 48.

Josephus Flavius, 17, 20, 30, 31, 34, 36, 38, 95, 108.

Josselyn, 142.

Jotham, 49.

Jovianus, 102.

Juba, 69, 88.

Julianus, 102.

Jussieu, 85.

Justinianus, 105

Justinus, 104.

Justinus II., 105. 


\section{NAMES OF PERSONS.}

K.

Kaempfer, E., 139, 142, 146, 147, 148.

Kafur, 118, 119.

Kaher, 117.

Kalaoon, 127.

Kalm, P., 139.

Kansu Abu-Said, 136.

Kansu Djan-balat, 136.

Kansu El-Gouri, 136.

Kasimirski, 106.

Kayt-Bay, 130, 134.

Kembath, or Cambyses, 56 .

Khalyl, 127.

Klaproth, 121.

Knorr, 150.

Koromelas, A., 46.

Koschkadam, 130.

Kotoz, 126.

Koutchouk, 127.

\section{L.}

Lane, E. W., 129, 140, 165.

Laodamas, 36.

Laurentius, 129.

Lenaeus, 86.

Lentulus, Cn. Cornelius, 160.

Leo, 104.

Leo II., 104.

Leo Africanus, 18, 79, 88, 104, 106.

Lepsius, 4 to $48,97,160$.

Lerius, J., 142.

L'Heritier, 151.

Libanius, 103.

Licinius, see Crassus.

Linnæus, C., 46, 58, 139, 141, 143, 146, $150,151$.

Linschoten, 144.

Lippi, A., 59, 143.

Livius, 83.

Livius Andronicus, 83.

Lloyd, G., 143.

Lobel, M., 72, 76, 84, 91, 93, 95, 112, 115, $116,119,123,130,131,133,134$ to 143 .

Loudon, 149.

Loureiro, 93, 151.

Lowell, 28.
Lucanus, 73,75 .

Lucianus, 70 .

Lucilius, 85.

Lucretius, 66.

Luke, 80 .

Lyeurgus, 48.

Lynch, 33.

Lysimachus, 159.

M.

Macer Floridus, 57, 68, 69, 79, 84, 96, 112,119

Macrinus, 98.

Macrobius, 60, 63, 85.

Madschhul, 123.

Magellan, 136.

Magnol, 147.

Mahmood, 150.

Mahmood II., 152.

Makrisi, 112, 115.

Malachi, 53.

Manardus, Johannes, 137.

Manetho, 5 to $51,159,161,162,163$.

Manfredus de Monte Imperiali, 129.

Manilius, 155, 160.

Mareel, J. J., 107 to 152.

Marcellus, 82.

Marco Polo, 50, 118, 126.

Mardoch-Empadus, 50.

Maregrave, G., 146.

Marcianus, 103.

Mark, 40, 93.

Martialis, 23.

Maserjawia, 47, 103, 109.

Masudi, 109.

Matthæus Sylvaticus, see Sylvaticus.

Matthew, 103.

Matthioli, P. A., 31, 72, 81, 92, 93, 103, $115,116,121,122,130,131,132,133$ to 141.

Matron, 69.

Mauricius, 105.

Maximinus, 98.

Maximus, Pupienus, 99.

Megasthenes, 61, 73.

Mehemet Arabs, 114.

Melanthius, 23. 
I N D E X.

Melek-Adel Seif-Eddin, 123.

Montaser, 114.

Melek-Adel II., 125.

Melek-Aziz Othman, 123.

Melek-el-Mansur, 123.

Melek-Kamel, 124.

Melek-Saleh, 125.

Menander Protector, 105.

Menecrates Elaita, 81.

Meneptha Sethos, 27, 160.

Meneptha II., 29.

Meneptha III., 30.

Menes; 5 .

Menkera, or Mycerinus, 12.

Menodotus, 38, 72.

Mentuatep, 14.

Mentuatep II., or Mentuatep Nebtura, 15.

Merenra, 15.

Merian, S. M., 144.

Meritetnacht, or Amyrtæus, 63.

Merodach-Baladan, see Mardoch-Empadus.

Merrira, 30.

Merwan, 109.

Merwan II., 111.

Mesarguil, 109.

Meseab, 109.

Mesue, 81, y8, 106, 107, 109, 110 to 120.

Micah, 32, 39.

Miller, 151.

Millington, J., 152.

Miseaben, 107.

Mithridates, 86.

Mizraim, see Ramses II.

Mnesimachus, 63 .

Mnesitheus, 58, 70 .

Moez, 119.

Mohammed, 106.

Mohammed III., 144.

Mohammed IV., 146.

Mohammed Abu-l-Saadat, 135.

Mohammed Ali, 152.

Mohammed El-Mansur, 128.

Mohammed Saleh, 129.

Mohtadi, 114.

Moktader, 117.

Moktafi, 116.

Monardes, N., 135, 136, 137, 140, 141, $142,143$.

Moses, 10 to 35, 36, 165.

Mosih Ben Elhakam, 114.

Morison, R., 147.

Mostaali, 121.

Mostakfi, 118.

Mostain, 114.

Mostain, 128.

Mostanser, 121.

Motadhed, 115.

Motaki, 118.

Motamed, 115.

Motassem, 113.

Motawakkel, 114.

Motaz, 114.

Mothi, 118, 119.

Mu'awiyah, 109.

Mu'awiyah II., 109.

Muller, C., 68, 162.

Munk, S., 117, 119, 122, 123, 124, 125.

Murad III., or Amurath III., 143.

Murad IV:, 145.

Musa, Antonius, 87.

Musæus, 46.

Mustafa, 145.

Mustafa II., 149.

Mustafa III., 151.

Mustafa IV., 152.

Mycerinus, see Menkera.

Myrepsus, see Nicolaus.

\section{N.}

Nabonassar, 160

Nachtenra, 15.

Nævius, 83.

Naser, 127.

Nearchus, 73.

Nechao, see Neku.

Nechtneb, or Nectanebus, 68.

Nechtneb II., 70.

Nectanebus, see Nechtneb.

Nefruatep, 19.

Nefrukera, 13.

Nefrukera II., 15.

Neku, Nechoh, or Nechao, 53.

Nentef II., 15. 


\section{NAMES OF PERSONS.}

Nepherites, 63.

Nero, 89.

Nerva, 96.

Nicander, $46,55,57,58,60,61,65,66$, 71 to 84 .

Nicolaus Damascenus, 52.

Nicolaus Myrepsus, 81, 90, 97, 103, 110, 111, 112, 126.

Nicolaus Præpositus, 91, 113, 122.

Nicolo Conti, 50.

Niederstedt, 50.

Niger, Pescennius, 97.

Nooreddin of Damascus, 123.

Nooreddin Ali, 126.

Nteriusch, or Darius, 28, 56.

Nteriusch II., 63.

Nteriusch III., 72.

Numerianus, 101.

Nuttall, 106, 152.

\section{O.}

Ochus, see Artcheschsesch.

Oldenland, 148.

Olivier, 133.

Omar, 107.

Omar II., 110.

Onesicritus, 73.

Onias, 85 .

Oribasius, 65, 84, 88, 92.

Orosius, 103.

Orpheus, 48.

Ortega, 151.

Osman, or Othman, 127.

Osman II., 151.

Othman, 108.

Othman, see Osman.

Othman El-Mansur, 129.

Otho, 93.

Othoes, see Atai.

Ouenephes, 6.

Ovidius, $65,75,76,81,83$.

Oviedo, 135, 137.

$$
\text { P. - }
$$

Palladius, 48, 64 .

Pallas, P. S., 139
Paludanus, Bernard, 118, 144.

Pamphos, 47.

Parkinson, J., 80, 116, 117, 120, 121, 131, 144, 145.

Pausanias, 47, 50, 51, 58, 97.

Pavon, 144.

Paxamus, 99

Peher, 41.

Peher Sesamen, 37.

Pepi, Apappus, or Phiops, 14.

Pepin, 111.

Pereira, 121, 136, 137, 145.

Persoon, C. H., 83, 141, 143, 146, 152.

Pertinax, 97.

Petpacht, or Petubastes, 48.

Petronius Diodotus, see Diodotus.

Petubastes, see Petpacht.

Phanias of Eresus, 36, 48, 69, 77.

Pherecrates, 30, 59, 62 .

Philippus Aridaeus, 74.

Philippus, M. Julius, 99.

Philistion, 48.

Philon Judæus, 34, 68 .

Philonides, 76.

Philostratus, 88, 98.

Philotimus, 81.

Philoxenus, 106.

Philoxenus of Cythera, 64.

Philyllius, 39.

Phocas, 106.

Photius, 105

Phrynichus, 48.

Pianch, 37.

Pindar, 45, 57, 58.

Pischam Miamn II., 38.

Piso, W., 137, 142, 146.

Placentius, Petrus, 134.

Plate, W., 101, 108, 109.

Plato, 46.

Plautus, 17, 23, 37, 39, 49, 72, 83 .

Plinius, 17 to $95,105,156,158,160$.

Plinius Secundus, 96.

Plukenet, L., 128, 131, 147, 148.

Plutarchus, 42, 60, 88, 92.

Pococke, R., 67, 92.

Poiteau, 143.

Polemon, 56, 71 . 


\section{N D E X.}

Pollio, Carvilius, 73.

Pollux, Julius, 23.

Polyænus, 42, 64.

Polybius, 18, 76, 160.

Posidonius, 168.

Posidonius, 18, 75, 96.

Pratinas, 57.

Priscianus, 103.

Prisse, 14, 48.

Probus, 100.

Propertius, 75, 83.

Proteus, see Peher Sesamen.

Prytanis, 48.

Psamtik, or Psammetichus, 51.

Psamtik II., 53, 54.

Psamtik III., 56.

Pseudo-Anacreon, 30.

Pseudo-Callisthenes, 98, 102.

Pseudo-Xanthus, 81.

Psimut, 48.

Ptolemæus, 74, 81 .

Ptolemæus II. Philadelphus, 43, 44, 62, $63,72,76,81$.

Ptolemæus III. Euergetes, 14, 82.

Ptolemæus IV. Philopator, 83.

Ptolemæus V. Epiphanes, 83.

Ptolemæus VI. Philometor, 83, 85.

Ptolemæus VII. Physcon, 85.

Ptolemæus VIII. Lathyrus, 85, 86.

Ptolemæus IX. Alexander I., 86.

Ptolemæus X. Alexander II., 86.

Ptolemæus XI. Auletes, 86.

Ptolemæus, Claudius, 50, 83, 159, 160, 161, 162, 163.

Ptolichus, 58.

Purchas, 142.

Pursh, 152.

Pythagoras, 55, 56.

Pythermus, 29.

\section{Q.}

Quakelbecn, 140.

Queen of Sheba, 38.

\section{R}

Radi, 117.

Rakamai, 20.
Ramsay, W., 99.

Ramses, or Ramessu, 27.

Ramses II., 28, 86, 158, 161.

Ramses III., 30.

Ramses IV., 31.

Ramses V., 31.

Ramses VI., 31.

Ramses VII., 31.

Ramses VIII., 35.

Ramses IX., 35.

Ramses X., 35.

Ramses XI., 35.

Ramses XII., 36.

Ramses XIII., 36.

Ramusio, 114.

Ransesr, 13.

Rauwolf, L., 42, 56, 89, 116, 129, 140, 141, 143.

Reboboam, 40 .

Reichard, 37.

Rhamnusis, 135.

Rhazes, 35, 42, 45, 47, 61, 76, 77, 78, 82, 92 to $117,124$.

Rheede, H. Van, 35, 88, 125, 135, 137, 144, 147.

Roemer, 156, 157.

Roger of Normandy, 121.

Rosselini, 6, 11, 14, 17, 25, 26, 27, 29.

Rouyer, 140, 145.

Royle, 40, 83, 92, 93, 110, 113, 116, 143 .

Roxburgh, 132.

Rudbeck, O., 46.

Ruellius, 123, 129, 133, 137.

Rufus Ephesius, 68, 90.

Ruiz, 144.

Rumphius, G. E., 88, 120, 125, 127, 134, 135,137 to 148 .

Ruppius, 138.

Ryme, 152.

\section{S.}

Sabacon, see Schebek.

Sahura, 13.

Saladdin, 123.

Salamesch, 127.

Salatis, 20.

Salvolini, 29. 


\section{NAMES OF PERSONS.}

Samson, 36.

Sanutious, see Shenouda.

Sappho, 39, 53.

Sarac, the Indian, 111.

Saul, 37.

Saunders, 114.

Scaliger, J. C., 139.

Scarlatus, 46, 55, 59, 65, 67, 80, 94 .

Schaban-Aschraf, 128.

Schaban-Kamel, 127.

Schafra, or Chephren, 9.

Schebek, or Sabacon, 49, 159.

Schebek II., 49 .

Scheschenk, or Shishak, 40.

Scheschenk II., 41.

Scheschenk III., 47.

Scheuchzer, 150.

Scholiast of Theocritus, 128.

Schreber, 151.

Schwartz, 149.

Schwarz, Rabbi, 47, 67, 70, 75, 153.

Scribonius Largus, 80.

Seba, 148.

Sebekatep II., 19.

Sebekatep III., 19.

Sebekatep IV., 19.

Sebekatep V., 19.

Sebekemsaf, 20.

Sebeknefrura, 19.

Seif-Eddin, 123.

Seif.Eddin Tattar, 129.

Sekennen-raken, 21.

Selim, 136.

Selim II., 141.

Selim III., 152.

Semus Delius, 57.

Senefru, 7.

Serapion Senior, 107.

Serapion, 33, 35, 43, 61, 104, 106, 107, 109 to 120 .

Serenus Sammonicus, 84, 93.

Sestini, 80.

Sesorthus, 6.

Sesurtesen, 16.

Sesurtesen II., 17.

Sesurtesen III., 18.

Severus, Alexander, 98.
Severus, Septimius, 97.

Shalmaneser, 50 .

Sharpe, S., 100, 105, 106.

Shekh Mahmoudi, 128.

Shenouda, or Sanutious, 115.

Shishak, see Scheschenk.

Sibthorp, 29 to 148 .

Sieber, 139

Simon de Tovar, 144.

Simonides, 48, 55 .

Sloane, Hans, 148, 149.

Smith, J. E., 84.

So, see Schebek.

Sogdianus, 63 .

Soliman, 110.

Solomon, 14 to 40 .

Solon, 42.

Sontheimer, 116

Sophocles, 14, 35, 39, 57, 60 .

Sophron, 60.

Soyouty, 115.

Sprengel, C., 62, 68, 92, 106, 112, 123, 125,129 to 150 .

Stapel, 83, 84, 94, 119, 137.

Stephanus, 118.

Stephanus, C., 138, 139.

Stesichorus, 42, 52 .

Strabo, 18, 50, 61, 73, 74, 80, 87, 168.

Strabus, Walafridus, 112.

Strattis, 38, 67.

Suetonius, 93.

Suliman II., 136.

Suliman III., 148.

Sylvaticus, Matthæus, 118.

Symeon Sethus, 94, 104, 110, 112, 118.

Symmachus, 104.

Symon Januensis, 127.

Syncellus, 27.

T.

Tabernæmontanus, 84, 137, 143

Tacitus, 30, 93.

Tacitus, M. C., 100.

Takelet, or Tiglath, 41.

Takelet II., 48.

Tamerlane, see Timur.

Tarquinius Priscus, 32. 
I N D E X.

Terentius, 83 .

Tertullianus, 34, 63, 73, 93, 103.

Tetkera, 13.

Tetmes, or Thothmosis, 22.

Tetmes II., 22.

Tetmes III., 23.

Tetmes IV., 25.

Thalius, 137, 141.

Thamyris, 36 .

Themistagoras, 52 .

Theocritus, 39, 53, 76, 77, 79, 81 .

Theodorus Gaza, see Gaza.

Theodosius, 103.

Theodosius II., 103.

Theognis, 24, 55.

Theophanes Byzantius, 105.

Theophrastus, 12 to 80 .

Theopompus, 46, 59, 67, 68, 70 .

Thiers, 21, 152 .

Thomas, 106.

Thoth (see Athothis), 4, 7.

Thrk, or Tirbakah, 50 .

Thucydides, 44, 51 .

Thunberg, 139, 142, 147, 148, 149.

Thuoris, see Peher Sesamen.

Tiberius, 75,88 .

Tiberius Constantinus, 105.

Tibullus, 39, 88.

Tiglath, see Takelet.

Timæus, 55.

Timar Bogha, 130.

Timaristus, 81.

Timocles, 39.

Timur, or Tamerlane, 128.

Tirhakah, see Thrk.

Titus, 95, 96.

Tochon, 100.

Toman-Bay, 136.

Toman-Bay II, 136.

Tooloon, 115, 116.

Turner, W., 138.
Turner, 114.

Tyrtæus, 50.

U.

Uaphres, see Hophra.

Userkan, 40.

Userkan II., 41.

Userkan III., 46.

Userkna, 48.

Useskef, 13.

Uzziah, or Azariah, 48.

V.

Valens, 102, 103.

Valentinianus, 102.

Valentinianus II., 103.

Valerianus, 99.

Valerius, Julius, 98

Van Cube, J., 130.

Vansleb, 143.

Varro, 17, 18, 79, 86, 99, 160.

Vertoman, or Barthema, 106, 117.

Verus, Lucius, 97 .

Vesling, 124, 132, 143, 146.

Vespasianus, 94.

Victor, 98.

Vincentius Bellovacensis, 127.

Virgil, 26, 28, 42, 45, 58, 59, 62, 65, 81, $85,87$.

Vitellius, 93 .

Vitruvius, 50, 66, 81, 87, 88.

Volckamer, 148.

Vyse, 53.

W.

Wahab, 98, 114.

Walid, 110.

Tournefort, J. P., 42, 61, 62, 64, 65, 94, Walid II., 111. 132 to 150 .

Tradescant, 146.

Tragus, Hieronymus, 84, 119, 122, 132, 135, 137, 138.

Trajanus, 96.

Turan Schab, 125.

Wathek, 113.

Wilkinson, 5, 18, 107, 108, 109, 113, 114, 115 to $125,128,136$.

Willdenow, 138, 139, 141, 142, 145.

Williams, R., 142.

Wood, 142. 


\section{NAMES OF PERSONS.}

$\mathrm{X}$

Xanthus, 37.

Xenarchus, 63, 64.

Xenocrates, 69.

Xenophon, 33, 34, 42, 60, 67.

Xerxes, see Cheschearscha.

Ximenes, 137.

Y.

Yezid, 109.

Yezid II., 110.
Yezid III., 111.

Ynal, 129.

Z.

Zalikoglous, 12, 42, 46, 71.

Zannoni, J., 147.

Zeno, 69 .

Zeno, 104.

Zenobia, 100.

Zephaniah, 39.

Zerah, see Userkan.

Zeyneddin, 127.

Zoega, 100.

Zosimus Panopolitanus, 110. 



\section{N D E X.}

$\Lambda$

Abies picea, 27.

Abrus precatorius, 129.

Absinth, 54 .

Abu Simbel, 29.

Abusir, 7, 13.

Abutilon vulgare, 141.

Abydos, 15, 19.

Abyssinia, 9, 15, 75, 82, 88, 105, 129 .

Acacia Farnesiana, 145.

Acacia gummifera, 145 .

Acacia heterocarpa, 107.

Acacia lebbeck, 149.

Acacia Nilotica, 18.

Acacia seyal, 2.

Acanthus mollis, 81 .

Acanthus spinosus, 82.

Acer campestre, 63 .

Acer platanoides, 94 .

Acer pseudo-platanus, 95.

Acer negundo, 149.

Achillea millefolium, 112.

Achyranthus argentea, 131.

Aconitum napellus, 70 .

Acorus calamus, 78 .

Adansonia digitata, 129.

Adiantum capillus veneris, 2.

Adobes, 6, 18 .

Adonis æstivalis, 60 .

Adriatic Sea, 46.

Adule, inscription at, 82 .

Aegle marmelos, 116.

Aerva tomentosa, 131.

Aeschynomene sesban, 123.
Esculus hippocastanum, 140.

Africa, cireumnavigated, 53.

Agapanthus umbellatus, 149.

Agave Americana, 139.

Ageratum conyzoides, 148.

Agricultural produce of Egypt, influence of, 107.

Agriculture, 3, 10.

Agrimonia, 89.

Agrostis alba, 124.

Ajuga iva, 82.

Akhmin, 83.

Alcea ficifolia, 47 .

Alcea rosea, 47 .

Alcoholic distillation, 122.

Alder, 45.

Alexandria, 24, 72, 74, 163.

Alhagi Maurorum, 42.

Alisma plantago, 90.

Allium cepa, the onion, 12.

Allium Askalonicum, the shallot, 12.

Allium ampeloprasum, 56.

Allium porrum, the leek, 56 .

Allium sativum, the garlic, 12.

Almond, 33.

Alnus glutinosa, 45 .

Aloe, 88 .

Aloexylum agallochin, 93.

Aloysia citriodora, 151.

Alphabet, 35, 36.

Alpinia galanga, 112.

Alternanthera sessilis, 131.

Althea cannabina, 79 .

Althea Ludwigii, 79. 
I N D E X.

Althea officinalis, 79 .

Amada, 23, 25 .

Amaranthus blitum, 64 .

Amaranthus tricolor, 95 .

Amaranthus viridis, 146.

Amarna, 26.

Amaryllis belladonna, 149 .

Amaryllis formosissima, 144

Amaryllis Sarniensis, 146.

Amber, 46.

Ambergris, 118.

Ambrosia maritima, 91.

Americans, the Aboriginal, 2, 134 to 143.

Ammania Agyptiaca, 85.

Ammania auriculata, 85 .

Ammi, 68 .

Ammi majus, 112.

Ammi visnaga, 78 .

Ammoniacum, gum, 92.

Amomum cardamomum, see Elettaria.

Amomum grana-paradisi, 124.

Amomum zingiber, 88.

Ampelopsis hederacea, 146.

Amygdalus communis, the almond, 33 .

Amygdalus Persica, the peach, 81 .

Amyris commiphora, 31.

Amyris kafal, 62.

Amyris opobalsamum, 38.

Anacardium Occidentale, 139.

Anagallis arvensis, 51.

Anas boschas, 17.

Anas moschata, 139.

Anatomy, early work on, 5 .

Anchusa officinalis, 119

Andropogon calamus-aromaticus, 75 .

Andropogon schœnanthus, 75 .

Anemone, 60.

Anethum graveolens, 53.

Anise, 56 .

Annona squamosa, 147 .

Antæopolis, 84 .

Antelopes, 3.

Anthemis cotula, 130 .

Anthemis grandiflora, 147.

Anthemis nobilis, 68 .

Anthemis pyrethrum, 84 .

Antholyza Ethiopica, 145.
Antimony, 23

Antirrhinum Egyptiacum, 90.

Antirrhinum elatine, 90.

Antirrhinum linaria, 132.

Ape, the cynocephalus, 9 .

Apis, the bee, 36 .

Apium graveolens, 45 .

Apium dulce, the celery, 136.

Apple, 39.

Apricot, 81 .

Aqueducts, subterranean, 115.

Arabs, 20, 52.

Arachis hypogea, 142.

Arch, pointed, 115.

Archers, Nubian, 11.

Archil, or Argol, 64.

Arehitecture, Greek, 16, 54 .

Architecture, Muslim, 115.

Areca catechu, 109.

Arenaria media, 133.

Arenaria rubra, 133.

Argemone Mexicana, 144.

Aristolochia, 71.

Aritbmetical processes among the people of Hindostan, 168.

Armeniaca, see Prunus.

Armoracia, see Horse-radish.

Arnica scorpioides, 78.

Arnotto, 137.

Arrows, foreign, Egyptian, and Nubian, 11.

Artemisia arborescens, 71

Artemisia abrotanum, 78 .

Artemisia absinthium, 54.

Artemisia dracunculus, 112.

Artemisia Judaica, 32.

Artichoke, 14.

Artillery, 136.

Arts and trades of the Anc. Egyptians, 17.

Arum esculentum, see Colocasia.

Arundo donax, 11.

Asarum Europæum, 82.

Asasif, 23, 26, 85.

Asclepias Curassavica, 149.

Asclepias fruticosa (Gomphocarpus), 148.

Asclepias procera (Calotropis), 33.

Ash, see Fraxinus.

Asia Minor, 20, 30. 
I N D EX.

Asp, or cobra, 4 .

Asparagus, 59.

Aspen, 41.

Assafoetida, 73.

Assuan, 15, 96.

Assyrian, or cuneiform writing, 54 .

Assyrians, 20, 23.

Aster Chinensis, 150.

Astragalus aristatus, 77 .

Astronomy, 11, 17, 74, 112, 154 to 168.

Athamantha Cretensis, 78.

Athens, 49.

Atriplex coriacea, 51.

Atriplex hortensis, 79 .

Atropa mandragora, 66.

Attar of rose, 40.

Aubergine, see Egg-plant.

Aucklandia costus, 75 .

Avena fatua, 124

Avena sativa, 71.

Avena sterilis, 124.

Azores, 106.

\section{B.}

Bab-el-Meluk, 27 to $31,35,36$

Babylon, 13, 17, 33, 50, 111.

Bachur ointment, 55, 124.

Bactria, 31, 75, 82 .

Bactrian camel, 47.

Bagdad, 111, 126.

Balance-beam for carrying burdens, 11.

Balanites, 143

Balm-tree, 38 .

Balsam-apple, 18.

Balsamita vulgaris, 102.

Baltic Sea, 46

Bamboo, 61.

Bambos arundinacea, 61.

Bamia, see Hibiscus esculentus.

Banana, 106.

Barbary, 18, 46.

Barberry, 79.

Barges, 6, 18.

Barkal, 28, 50.

Barley, 13.

Bathenians, or Hassassins, 122, 126.
Bdellium, 31.

Bean, see Vicia and Phaseolus.

Bear, 24.

Beaver, 61.

Bedouins, 17.

Bee, 36.

Beech, 80.

Beer, or booza, 19.

Beet, 23.

Bengal, 55.

Benibassan, 5, 7, 8, 9, 10, 16, 17, 18, 20.

Benzoin, 124.

Berberis Cretica, 88.

Berberis lycium, 93.

Berberis vulgaris, 79 .

Beta vulgaris, 23.

Betel, 109.

Betonica alopecurus, 87.

Betula alba, 80 .

Bezoars, 117.

Bigeh, 25.

Bignonia catalpa, 150.

Bignonia radicans, 146 .

Birch, 80 .

Birdlime, 25.

Birds, as hieroglyphic characters, 4 .

Biscutella apula, 85 .

Biscutella depressa, 85 .

Bistort, see Polygonum bistorta.

Bitumen, 28.

Bixa Orellana, 137.

Blue earth, 25.

Books, 4, 5, 7, 10, 19.

Booza, 19.

Borage, 92.

Borago Africana, 92.

Borago officinalis, 92 .

Borax, 114.

Borysthenes, 33.

Bos bubalus, 102.

Boswellia thurifera, 23.

Botanic garden, establisbed in Egypt, 153.

Bows, metallic, 29.

Box-wood, 44.

Brassica eruca, 76 .

Brassica napus, 59 .

Brassica oleracea, 55. 
I N D E X.

Brassica rapa, 64 .

Brazil, 118, 139 to 153 .

Bread, 53.

Bricks, sun-dried, or adobes, 6, 18.

Britain, 87, 94, 97, 105, 154.

Bromelia ananas, 135.

Bromus distachyos, 133.

Bromus mollis, 133.

Bromus rubens, 133.

Bronze, 15.

Brugmansia candida, 153.

Bryonia Cretica, 69.

Bryonia dioica, 69.

Bubastis, 40, 85.

Bubon Macedonicum, 89.

Buckwheat, 137.

Buffalo, 102.

Bullock, 8, 17, 154.

Bullock, the Indian, 17, 18.

Bupleurum rotundifolium, 82.

Bupleurum semicompositum, 82 .

Buxus sempervirens, 44.

C.

Cabbage, 14, 55 .

Cabinet furniture, 30 .

Cacalia Kleinii, 144.

Cactus coccinellifer, see Cochineal.

Cactus Opuntia, 138.

Cæsalpinia sappan, 118.

Cairo, founded, 119.

Caladium, see Colocasia.

Calamus aromaticus, 75 .

Calamus rotang, 144.

Calendars, 6, 154 to 165 .

Calendula arvensis, 52 .

Calendula officinalis, 52.

Callitris quadrivalvis, 114.

Calotropis procera, 33.

Calystegia, see Convolvulus.

Camel, 32.

Camel, two-humped, 47.

Camellia Japonica, 148.

Camelus Bactrianus, 47.

Camelus dromas, 32.
Camphor, 109.

Camphor, precious, 114.

Canal Bahr Yusuf, 5.

Canarium commune, 120.

Canary bird, 140.

Canna Indica, 140.

Cannabis sativa, 61 .

Canopus, the star, 168.

Caper bush, 39.

Capparis spinosa, 39.

Capra hircus, 9.

Capra ibex, the capricorn, 8.

Capricorn, 8.

Capsella bursa-pastoris, see Thlaspi.

Capsicum, 135.

Caraway, 92.

Cardamoms, 74

Cardiospermum helicacabum, 122.

Carduus Marianus, 91.

Carex, the genus not found in Egypt, 3.

Carica papaya, 137.

Carnation, 129.

Carob tree, 49.

Carrier-pigeons, 30.

Carrot, 48.

Carthamus tinctorius, 43.

Carum carvi, 92.

Caryophyllus aromaticus, cloves, 94 .

Caspian Sea, 18.

Cassia absus, 92.

Cassia fistula, 103.

Cassia lanceolata, 107.

Cassia Occidentalis, 149.

Cassia obovata, 34.

Cassia sophera, 130.

Cassia tora, 109.

Castanea, the chestnut, 70 .

Castor, the beaver, 81 .

Castor bean, 61 .

Cat, the domestic, 52.

Catalpa, 150.

Cataracts of the Nile, 11, 16, 18 .

Cattle, see Bullock.

Caucalis daucoides, 37 .

Caucasian Countries, 47.

Cauliflower, 55 .

Celebes, island of, 120 . 
I N D E X.

Celery, 45, 136.

Celosia coccinea, 142.

Celosia cristata, 134.

Celosia margaritacea, 131.

Celtis Australis, 80.

Celtis Occidentalis, 146

Centaurea behen, 116 .

Centaurea calcitrapa, 34 .

Centaurea cyanus, 94.

Centaurea moschata, 60 .

Central Africa, 9, 10, 15, 19, 88, 122, 130, 143.

Cerastium viscosum, 141.

Cerastium vulgatum, 141.

Cerasus, see Cherry.

Ceratonia siliqua, 49.

Cercis siliquastrum, 80 .

Cercopithecus, 10.

Cervus elaphus, the stag, 18 .

Chærophyllum sativum, 62 .

Chamæriphis, 131.

Chameleon, 3 .

Chamomile, 68 .

Charcoal, traffic in, 38.

Charlock, 59 .

Checkered baskets, 5 .

Cheeta, or hunting leopard, 18.

Cheiranthus cheiri, 84.

Cheiranthus incanus, 76 .

Chelonia, sea-tortoise, 73 .

Chemistry, Ancient Egyptian, 50.

Chenoboskion, 15.

Chenopodium album, 85.

Chenopodium ambrosioides, 145.

Chenopodium bonus Henricus, 130.

Chenopodium murale, 85 .

Chenopodium rubrum, 85 .

Chequers, game of, 30 .

Cherry, 80.

Chestnut, 70.

Chichorium endivia, 57.

Chichorium intybus, 57.

Chick-pea, 41.

Chickweed, 123.

Child-stealing, 43 .

China, 17, 35, 65, 114, 154.

China root, 139.
Chinese writing, and manufactures, $86,88$.

Chocolate, 139.

Christian Era, 105, 164.

Christians, the Early, 93, 95, 97, 99, 100, 102, 106.

Chronological subjects, the Date-palm connected with, 7 .

Chrysanthemum coronarium, 84.

Chrysanthemum Indicum, 147.

Chrysanthemum segetum, 84 .

Chunam, 5.

Churches in Egypt, 100, 101.

Cicer arietinum, 41.

Cimex lectularius, 63 .

Cineraria maritima, 126.

Cinnabar, 65.

Cinnamon, 35.

Cipher writing, 27.

Circle, properties of the, 165 .

Cissus rotundifolia, 131.

Cirsium Syriacum, 37.

Cistus, 62 .

Citron, 69 .

Citrullus, the water-melon, 14.

Citrus acida, the lemon, 117.

Citrus aurantium, 117.

Citrus decumana, the shaddock, 153.

Citrus limonum, 117.

Citrus Medica, 69

Civet, 122.

Cleome pentaphylla, 125.

Climate of Egypt, 3.

Cloves, 94.

Clubs, Nubian, 18.

Cnicus benedictus, 99 .

Cobra, or asp, 4.

Coceulus Indicus, 99 .

Coccus cacti, 136.

Coccus ilicis, 17.

Coceus lacca, 116.

Cochineal, 136.

Cochlearia armoracia, 134.

Cochlearia officinalis, 95 .

Cocoa nut, 98.

Cocos nucifera, 98 .

Coffea Arabica, 129.

Coffee, 129. 
I N D E X.

Coins, 56, 58, 86, 87, 89 to 100, 101, 105, Coronopus Ruellii, 133.

109 to $128,130,136$ to 152 .

Coix lachryma, 106.

Colchians, 50.

Colchicum autumnale, 78 .

Coleseed, 59.

Colocasia esculenta, 85 .

Colocynth, 72.

Colossi, 16, 22, 25, 26, 86, 87, 108.

Columba, see Pigeon.

Column at Alexandria, 101.

Commerce, 5, 6, 24, 38, 134.

Comoro Islands, 88.

Compass, the mariner's, 121.

Conium maculatum, 119.

Constantinople, 24, 101.

Constellations, 11, 163, 168.

Contra-Latopolis, 97.

Convallaria majalis, 137.

Convolvulus arvensis, 128.

Convolvulus althæoides, 143.

Convolvulus batatas, 134.

Convolvulus Cairicus, 132.

Convolvulus nil, and C. hederaceus, 140 .

Convolvulus sepium, 95.

Convolvulus scammonia, 29.

Convolvulus Siculus, 29.

Convolvulus turpethum, 109.

Conyza Egyptiaca, 56.

Conyza Dioscoridis, 56.

Copaifera officinalis, 142.

Copal, 88.

Copper and copper-mines, 6, 109, 110.

Coptic inscriptions, 100.

Copts, 95, 104, 115, 164.

Corchorus olitorius, 117.

Cordia crenata, 113.

Cordia mixa, 24, 25, 113.

Coreopsis tinctoria, 152.

Coriander, 69.

Coriandrum sativum, 69 .

Cork, 58.

Cornel, 44.

Cornelian, 6.

Cornus mascula, 44.

Cornus sanguinea, 44.

Coronation, by priests, 104 .

Corylus avellana, 65 .

Costume of the Egyptians, 5.

Costume of foreign nations, 17.

Costus, 75 .

Cotton, 54 .

Cow, 154

Crane, 8.

Crassulaceæ, not found in Egypt, 3.

Cress, see Nasturtium.

Crocodilopolis, 16.

Crocus, 25.

Croton tiglium, 113.

Croton tinctorium, 61.

Crown-imperial, 140.

Crusades, 121 to 125.

Crypsis aculeata, 133.

Crypsis alopecuroides, 133.

Cubebs, 113.

Cucumber, the hairy, 14, 15.

Cucumber, the garden, 114.

Cucumis chate, 14.

Cucumis colocynthis, 72.

Cucumis melo, the musk-melon, 48 .

Cucumis sativus, 114

Cucurbita pepo, 142.

Cucurbita polymorpha, 142.

Cuminum eyminum, 49.

Cummin, 49.

Cupressus sempervirens, 44.

Curcuma longa, 39.

Curcuma zerumbet, 96 .

Currants, 138, 150.

Cuscuta, 71.

Custard-apple, 147.

Cycle of Time, 27, 36, 155.

Cydonia vulgaris, 42 .

Cycas circinalis, 147.

Cynara scolymus, 14.

Cynocephalus, or ape, 9.

Cynodon dactylum, 76 .

Cynoglossum officinale, 84 .

Cyperus alopecurus, 85 .

Cyperus articulatus, 145.

Cyperus dives, 85 .

Cyperus esculentus, 107.

Cyperus rotundus, 45 . 
I N D E X.

Cypress, 44.

Cyprus, 30, 54.

Cyrene, 53.

\section{D.}

Dactylis glomerata, 133.

Dactyloctenium, 131.

Dahlia variabilis, 152.

Dakkeh, 82, 83, 85, 96.

Daphne, 59 .

Dariks, 56.

Daschur, pyramids at, $6,18$.

Date palm, 7, 15, 51 .

Datisca cannabina, 132.

Datura fastuosa, 103.

Datura metel, 103.

Datura stramonium, 146.

Daucus carota, 48 .

Dead Sea, 33.

Debot, 87,88 .

Deccans, or weeks of ten days each, 165 .

Deed, for sale of land, 86 .

Degree of Latitude measured, 112.

Delos, 34, 51.

Delphinium ajacis, 46.

Demotic, or Enchorial writing, 52.

Dendera, 87, 88, 89, 96, 97.

Dendur, 87.

Dianthus caryophyllus, 129 .

Digitalis purpurea, 121.

Digitaria filiformis, 123.

Digitaria sanguinale, 123.

Dill, 53.

Diocletian Era, 118, 163, 164.

Dionysian Era, 81, 164.

Dioscorea, the yam, 135.

Diospyrus lotus, 139.

Dipsacaceæ, 3.

Dipsacus fullonum, 93.

Distillation, alcoholic, 122.

Dodder, 71.

Dog, 8, 52 .

Dolichos lablab, 113.

Dolichos lubia, 69.

Domestic fowl, 24.

Dongola, 14, 18, 28, 114.
Donkey, 9.

Dorema ammoniacum, 92.

Doric architecture, 16.

Doronicum pardalianches, 78 .

Doum palm, 5, 15.

Dourra, 98.

Dracæna draco, 66.

Dracocephalum Moldavicum, 141.

Dragon's blood, 66 .

Draughts, game of, 30 .

Droseraceæ, not found in Egypt, 3.

Drugs, the traffic in, 5 .

Druses of Lebanon, 120.

Dryobalanops, or precious camphor, 114.

Ducks, 17, 139

E.

Earthen ware, art of making, 9.

Earthquakes, 105.

East Africa, 24, 38, 86, 88 .

Easter, $97,98$.

Eastern Asia, 50, 65, 73, 88, 105, 110.

Ebony, 19

Ecelesiastical Councils, 97, 98, 101, 104

Echinochloa crus-galli, 132.

Echinochloa Italica, 22, 33.

Echium rubrum, 65 .

Eclipses, Babylonian series, 50.

Eclipses of Jupiter's satellites, 158 .

Eclipta erecta, 85 .

Edfu, 23, 83, 85, 89.

Egg-plant, 112.

Eguisse, 23.

Elæagnus Orientalis, 92.

Elæodendron argam, 107.

Elaterium, 58.

Elatine verticillata, 85 .

Elder, see Sambucus.

Elecampane, 78.

Elephant, the African, 15, 24.

Elephant, the Indian, 24.

Elephantine, 23, 26, 27, 31, 54.

Elettaria cardamomum, 74 .

Eleusine coracana, 146.

El Kab, tombs at, 9, 21, 22, 67.

Elm, 44.

Emblica officinalis, 110. 
I N D E X.

Endive, 57.

Equinox, Ptolemy's observation on, 159 .

Equus asinus, 9 .

Equus caballus, 22.

Era, Christian, 105, 164.

Era, Diocletian, 118, 163, 164.

Era, Dionysian, 81, 164.

Era of Gaza, the Second, 160.

Era of Nabonassar, 160.

Ericaceæ, not found in Egypt, 3.

Erigeron Canadense, 147.

Erinaceus auritus, 8 .

Erodium crassifolium, 79.

Erodium glabellum, 79.

Erodium malacoides, 79 .

Erodium reflexum, 79.

Ervum ervilia, 70.

Ervum lens, 32.

Erythræa centaurium, 3, 66 .

Esneb, 23, 82, 83, 88, 89, 94, 96, 97, 98.

Ethiopian or Nubian Race, 5, 8, 11, 18, 22.

Ethulia conyzoides, 85 .

Etruscan vases, 31, 47.

Euphorbia antiquorum, 88.

Euphorbia calendulifolia, 152.

Euphorbia helioseopia, 90.

Euphorbia peplis, 68

Euphorbia peplus, 90.

Euphorbia thymifolia, 131.

Euphorbia tirucalli, 147.

Euphrates, 28.

Exodus, date of the, 36, 159, 165.

Eye-paint, 23, 86.

\section{F.}

Faba, see Vicia faba.

Fagus sylvatica, 80 .

Faium, 16.

Fan, the flag-shaped, figured, 5.

Fellahs, or Egyptian peasants, 155.

Fennel, 57.

Fenugreek, 43.

Ferns, rare in Egypt, 2 ; figured at Karnak, 27.

Ferula, 73, 82.

Festuca uniglumis, 133.
Ficus carica, 10.

Ficus sycomorus, 23.

Fig, 10, 15.

Filbert, 65 .

Fine Arts, 25, 28, 52.

Fir tree, 27.

Fish, curing, 11.

Fish-glue, or isinglass, 61 .

Flax, 5 .

Flea, 37.

Florida, 138, 143, 152.

Fly, the biting, 34 .

Fly, the house, 34, 39.

Fly, the meat, 97.

Fœniculum vulgare, 57.

Foreigners, figured, 7, 17, 22, 24.

Fortified places, 17, 20.

Fox, 8.

Foxglove, 121.

Fowl, the domestic, 24.

Fractions, arithmetical, 167.

Fragaria vesca, 81.

Fragaria Virginiana, 145.

Frankincense, 23.

Frankincense-wood, 62.

Fraxinus excelsior, 42.

Fraxinus ornus, 42.

Fringilla Canaria, 140.

Fringilla domestica, 4.

Fritillaria imperialis, 140.

Fumaria capreolata, 90 .

Fumaria officinalis, 90 .

Fumaria parviflora, 90.

Funeral papyri, 27.

Furs, 28.

G.

Galanga, 112.

Galbanum, 35.

Galega officinalis, 134.

Gambia, 122.

Gamboge, 145.

Game, 3.

Garden-basil, 57.

Gardenia florida, 147.

Garden-plans, figured, 5, 17, 23, 26. 


\section{N D E X.}

Garlic, 12.

Garnets, 6.

Gebel-Addah, 26.

Gems, the traffic in, 6 .

Genealogical Table at Karnac, 24; at Abydos, 28; Ptolemaic, 74.

Genette, 3.

Gentiana lutea, 84.

Gentianaceæ, rare in Egypt, 3.

Geometry, 7.

Ginger, 88.

Girgeh, 30.

Gizeh, 9, 10, 11, 12, 13, 14, 25, 53, 89.

Glass money, 122.

Glaucium violaceum, 78.

Gleditschia triacanthos, 149.

Globulariaceæ, rare in Egypt, 3.

Glycyrrhiza, 77.

Gnaphalium Germanicum, 94.

Gnaphalium stoechas, 52 .

Goat, 9.

Gods, the Egyptian, 4, 16, 21, 52, 84, 99.

Gold, 6, 87, 100, 118, 120, 121 .

Gomphocarpus fruticosa, see Asclepias.

Gomphrena globosa, 88.

Goose, 8.

Gooseberry, 134; the North American, 144.

Gossypium, cotton, 54.

Gossypium vitifolium, 148.

Gourd, 30, 31, 48.

Grain, 10.

Grains of Paradise, 124.

Grangea, 85.

Granite, 16.

Grape, 10.

Great Bear, the constellation, 168.

Great Year, 27, 36, 155.

Greek alphabet, 58.

Greek architecture, 16, 54.

Greek fire, 109.

Greek language, 41.

Greeks, 25, 30, 51, 54, 130, 153.

Greyhound, 8.

Groves, cultivated, 6.

Grus, or crane, 8.

Guaiacum, 136.

Guava, 137.

Guinea, 106.

Guinea-fowl, 72.

Gum-Arabic, 62.

Gums, the traffic in, 5, 33.

Gunpowder, 126, 136.

Gurna, 15, 16, 26, 27, 36.

\section{H.}

Habits of the early Egyptians, 10, 11.

Hamamat, 14, 20.

Hare, 18.

Hassassins, or Bathenians, 122, 126.

Heaths, not found in Egypt, 3.

Hebradendron gambogioides, 145.

Hebrew letters, 100.

Hebrew names of plants, 41 .

Hedera, 57.

Hedgehog, 8.

Helianthus annuus, 141.

Helianthus tuberosus, 145 .

Heliopolis, 16, 74.

Heliotropium Europæum, 79 .

Heliotropium supinum, 79.

Helleborus Orientalis, 65.

Hemerocallis fulva, 142.

Hemerocallis Japonica, 148.

Hemlock poison, 37.

Hemp, 61.

Henna, 73.

Herculaneum and Pompeii, 95.

Hermontbis, 87.

Hesperis acris, 76 .

Hibiscus abelmoschus, 130 .

Hibiscus esculentus, 115.

Hibiscus palustris, 142.

Hibiscus rosa-sinensis, 146.

Hibiscus Syriacus, 127.

Hibiscus trionum, 131.

Hieratic writing, 14, 15.

Hieroglyphic characters, 4, 11, 52.

Himalaya Mountains, 73, 113, 120.

Himyaritic monuments, 32.

Hindostan, 4, 10, 11, 15, 24, 31, 38, 39, 40, $50,53,54,58,61,65,66,68$ to 154 .

History, written, the commencement of, 31 .

Hollyhock, 47. 


\section{N D E X.}

Honey-bee, 36.

Hop, 111.

Hordeum jubatum, 150.

Hordeum murinum, 91.

Hordeum vulgare, 13.

Horse, 22.

Horsechestnut, 140.

Horseradish, 134.

Hospital, 127.

House-fly, 39.

Humulus lupulus, 111.

Hunting-scenes, 18.

Hyacinthus Orientalis, 141.

Hyæna, 3, 10.

Hyksos, 16 to 23, 162.

Hyoscyamus albus, 67.

Hyoseyamus datura, 67.

Hyperboreans, 34.

Hypericaceæ, not found in Egypt, 3, 66.

Hypericum crispum, 66.

Hyphæne crinita, 5.

Hyssopus officinalis, 119.

Hystrix, the Porcupine, 13.

\section{I.}

Ibex, or capricorn, 8 .

Ibis, 7 .

Ibrim, 22, 23, 25.

Ichneumon, 3.

Idolatry, 4, 21.

Impatiens balsamina, 131.

Incense, 23.

India, see Hindostan.

India ink, 88.

Indigo, 25, 50 .

Indigofera, 25, 50.

Indo-Chinese countries, 35, 93, 116, 148.

Inscriptions, hieroglyphic, 4 to 99 ; Hieratic, 15; Greek, 36, 58, 72 ; Assyrian, or cuneiform, 47, 54; Demotic, or Enchorial, 52, 83; Phœnician, or Punic, 67 ; Latin, 87 ; Hebrew, 100 ; Coptic, 100, 118; Kufic, 113 to 136; Arabic, 118. Insects, figured at Benihassan, 17.

Inula helenium, 78.

Inula odora, 49 .
Ipecacuanha, 146.

Ipomæa nil, and I. hederacea, 140.

Ipomæa quamoclit, 143.

Iris Florentina, 67.

Iris sisyrinchium, 13.

Iron, 29.

Irrigation, 3.

Isatis tinctoria, 87.

Italy, 31, 45, 46, 58, 83, 160 .

Ivory, 15, 24.

Ivy, 57.

J.

Jackal, 8 .

Jacobites, 104.

Japan, 114, 147.

Jasminum grandiflorum, 114.

Jasminum odoratissimum, 120.

Jasminum officinale, 114.

Jasminum sambac, see Mogorium.

Java, 124.

Javelin, 17.

Jerusalem, 23, 40, 49, 53, 96, 121, 125.

Jews, 50, 85, 96, 102.

Juari, or dourra, 98.

Juglans regia, 39 .

Jujube, 89 .

Julian Period, 163.

Juncus odoratus, 75 .

Juniper berries, 43 .

Juniperus oxycedrus, 43.

Jupiter, the planet, 158.

Jussiæa diffusa, 85.

Justicia adhatoda, 147.

K.

Kalabsheh, 25, 87.

Kalanchoe Agyptiaca, 130.

Karnak, 15, 16, 22, 23, 24, 25, 27, 31, $40,48,51,83,88$.

Kaschgar, 110.

Kauamat, 15.

Kermes, 17.

Kerria Japonica, 148.

Kharesmians, 125. 


\section{N D E X}

Kidney-bean, 138

Kings, Egyptian, their number, 51.

Konosso, 20.

Koos, 83, 85.

Koran, 106, 107.

Kosser Road, 14, 18, 20, 56, 58.

Kufic inscriptions, 113 to 136.

\section{$\mathrm{L}$.}

Lablab, 113.

Labyrinth, 19.

Lac, 116.

Lactuca sativa, 52 .

Ladanum, gum, 62.

Lagenaria, the gourd, 30, 31, 48.

Lagerstrœmia Indica, 147.

Lagurus ovatus, 76.

Lamium amplexicaule, 134.

Languages, 7, 19, 29, 41, 154, 162.

Lantana camara, 146.

Lappago racemosa, 132.

Lathyrus aphaca, 77.

Lathyrus sativus, 69 .

Latin or Roman literature, 83.

Laurel, 44.

Laurus, 93 .

Laurus camphora, 110.

Laurus cassia, 83.

Laurus nobilis, 44 .

Laurus sassafras, 143 .

Lavandula spica, 40 .

Lavandula støechas, 40 .

Lavatera arborea, 132.

Lavatera Cretica, 132.

Lavender, 40.

Lawsonia, 73.

Lead, 35.

Leather, 38.

Lebanon, 27.

Leek, 56 .

Leersia oryzoides, 151.

Lemna gibba, 90 .

Lemna polyrhiza, 90 .

Lemon, 117.

Lemon-grass, see Andropogon schœnanthus, 75 .
Lentil, 32.

Leonurus cardiaca, 126.

Leopard, 9.

Leopard, the hunting, 18.

Lepidium sativum, 64.

Lepidium latifolium, 91.

Lepidotum, 30.

Lepus cuniculus, 18.

Lettuce, 52.

Levisticum, 92.

Library at Alexandria, 74, 81, 83, 103.

Lichen rocella, 64 .

Lichens, rare in Egypt, 2.

Light, theory of its progressive motion, 156 to 158

Light-house, or pharos, built at Alexandria, 74,81 .

Lign-aloes, 93.

Ligusticum Peloponnense, 141.

Lilac, 121.

Lilium candidum, 45.

Lilium Chalcedonicum, 59.

Lilium martagon, 59

Lily, 45.

Lily of the valley, 137.

Lime, 117.

Linden, 63.

Linen, 5.

Linum usitatissimum, 5 .

Lion, 3.

Liquorice, 77.

Literature, Egyptian, 4, 12, 19, 21, 22, 27, 28 ; of other nations, 31 ; Greek, 36 ; Roman, 83; Syriac, 106; Muslim, 106.

Loire, 111.

Lolium perenne, 20.

Lolium temulentum, 20.

Lote tree, 22.

Lotus Argolicus, 43.

Lotus corniculatus, 43.

Lotus, or water-lily, 10, 61.

Lovage, 92.

Lucerne, 28.

Luffa, 124

Lupine, the edible, 41.

Lunar Calendar, 164.

Lunations, 164. 
I N D E X.

Lupinus termes, the edible lupine, 41. Luxor, 26, 27, 83.

Lycopersicon esculentum, see Tomato.

Lycium Europæum, 60.

Lythrum hyssopifolium, 138.

M.

Macassar, 120.

Maccabee coins, 67.

Macer bark, 93 .

Madagascar, 19.

Madder, 68.

Madeira, 117.

Magellan, Straits of, 136.

Magnetic needle, or mariners' compass, 121.

Maize, 47, 135.

Malay countries, 24, 62, 68, 74, 106, 120, $124,127,148$.

Mallow, cultivated in Egypt, 47.

Malva alcea, 90.

Malva rotundifolia, 46 .

Malva sylvestris, 46 .

Malva verticillata, 47.

Mangifera Indica, 139.

Mango, 139.

Manna, 42.

Manufactures and Mechanic Arts, 17, 52.

Maple, 63.

Marking-nut, 97.

Marrubium alyssum, 77.

Massara, 21.

Mastich tree, 62.

Mathematical science, 7 .

Matricaria chamomilla, 91.

Mauritania, or Barbary, 18.

Mecca, 98, 108, 117.

Media, 50.

Medicago sativa, 28.

Medicine, early work on, 5 .

Medinet Habu, a temple at Thebes, 22, 23, $30,31,50,6 \overline{7}, 68,85$.

Meleagris gallipavo, the turkey, 135.

Melia azederach, 141.

Melianthus major, 146.

Melilotus coerulea, 138.
Melilotus Cretica, 60.

Melilotus Messanensis, 60.

Melilotus officinalis, 60.

Melissa officinalis, 77.

Melons, 14, 15, 48.

Memluks, 125 to $\mathbf{1 5 2 .}$

Memphis, 21, 53.

Menispermum cocculus, 99 .

Mentha glabrata, 55 .

Mentha pulegium, 51 .

Mentha rotundifolia, 134.

Mentha sativa, 55.

Mentha sylvestris, 58 .

Mercurialis, 66.

Mesembryanthemum crystallinum, 148.

Messenian War, 50.

Meroe, 15.

Mexico, 136 to 152.

Military campaigns, $5,7,11,13,16,17$, 22,25 to $30,53,74,82$.

Military posts, 20.

Millet, 22, 33, 60.

Mimosa habbas, 75 .

Mimosa pudica, 139.

Mimosa tortilis, 116.

Mimusops elengi, 107.

Mines of copper, 6 .

Mint, 51, 55, 58.

Mirabilis jalapa, 144.

Mocha, 9, 35, 38, 122.

Mode of carrying burdens, 11.

Mogorium sambac, 116.

Mollugo verticillata, 149.

Molucea Islands, 94, 107.

Momordica balsamina, 18.

Momordica elaterium, 58.

Momordica pedata, 150.

Monasteries of Egypt, 101, 105.

Money, 56, 58, 67, 89, 100, 110, 123.

Monkey, 10, 117.

Months, Egyptian, 6, 159 to 165; Hebrew, 165; Muslim, 165.

Monumental history of Egypt, 4, 6; of

Nineveh, 31; of Greece, 31; of Italy, 31.

Moringa oleifera, 75 .

Morning-glory, 140.

Morocco-leather, 38. 


\section{N D E X.}

Morus alba, 105.

Morus nigra, 29.

Moschus moschiferus, 104.

Mosques, 108 to 130 .

Mosses, rare in Egypt, 2.

Mouse, 49.

Mulberry, 29, 105.

Mullein, 63.

Mummies, 16, 25, 27, 38, 45, 46, 68, 102.

Mummy cases, 4, 5, 6, 12, 15, 19, 20, 23, $25,27,50$.

Mus decumanus, 139.

Mus musculus, 49 .

Mus rattus, 138.

Musa sapientum, 106.

Musca domestica, the house-fly, 39 .

Musea vomitoria, 97.

Muscari comosum, 64 .

Music, 7.

Musical instruments, 7 .

Musk, 104.

Musk-duck, 139.

Musk-melon, 48.

Muslims, 107 to 164 .

Mustard, 39, 55.

Myristica moschata, 107

Myrobalans, 110, 111.

Myrrh, 35.

Myrtle, 25, 26.

Myrtus communis, 25, 26.

Mythology of the Egyptians, 4, 10, 12, 21, 22, 52, 74; of the Hindoos, 4, 10.

N.

Napata, 14.

Narcissus jonquilla, 141.

Narcissus poeticus, 47 .

Narcissus tazetta, 47.

Nard, 40, 57.

Nardostachys jatamansi, 40 .

Nasturtium officinale, 86.

Naval combats, 30, 108.

Navigation on the Nile, 6 ; on the Mediterranean, $6,12,27,30$; on the Red Sea, and along the coasts of the Indian
Ocean, $24,35,38,53,65,74,86,88$, 136 ; Oceanic, 134, 153.

Neck-pillow of the Nubians, figured, 5.

Negro Race, 12.

Nelumbium, 26.

Nepeta cataria, 112.

Nerium oleander, 87.

Nettle, 64.

New Year, the Egyptian, 164, 165.

New Zealand, 151.

New Zealand flax, 151.

Nicandra physalodes, 150.

Nicotiana rustica, 140.

Nicotiana tabacum, 140.

Nigella arvensis, 91.

Nigella Damascena, 91 .

Nigella sativa, 53.

Nile, 3, 155.

Nilometers, 109, 110, 114, 121.

Nineveh, 31, 47.

Nitric acid, 50.

North America, the aboriginals of, 142

Northern China, 140.

Nubia, 16, 18, 23, 24, 25, 26, 27, 83.

Nubians, 5, 8, 11, 18.

Number, properties of, 166 .

Numerals, 7, 166.

Numida meleagris, 72 .

Nut-galls, 28.

Nutmeg, 107.

Nux vomica, 113.

Nymphæa cærulea, 10.

Nymphæa of Zanzibar, 10.

Nymphæa lotus, 61.

Nymphæa stellata, 11.

O.

Oak, 28.

Oars, 6, 9 .

Oases, 56, 89, 93, 97.

Oat, 71 ,

Obelisks, 16, 23, 26, 27, 52, 54, 74, 87, 89, 101, 102.

Obsidian, 15.

Ochra, 115.

Ocymurn basilicum, 57. 


\section{N D E X.}

Oenothera biennis, 145.

Offerings and sacrifices, 10 .

Oil, 52, 59, 61, 107.

Olea Europea, 32.

Oleander, see Nerium.

Olibanum, 23.

Olive, 32.

Olympiads, 36, 48, 164.

Oman, or Eastern Arabia, 69, 117.

Ombos, 23, 83, 96.

Onagraceæ, not found in Egypt, 3.

Onion, 12

Onobrychis crista-galli, 77.

Onobrychis sativa, 141.

Onopordum Græcum, 60 .

Opium, 43.

Opopanax chironium, 78, 82.

Opuntia, 138.

Orache, 79.

Orange, 117.

Orchidaceæ, not found in Egypt, 3.

Origanum Egyptiacum, 67.

Origanum dictamnus, 72.

Origanum majorana, 67.

Orris-root, 67.

Ornithogalum Arabicum, 46.

Ornithogalum elatum, 132.

Ornithogallum umbellatum, 46.

Ornus, see Fraxinus.

Oryx, 8.

Oryza, or rice, 74 .

Ostrich, traffic in the eggs and feathers, 7.

Ottelia alismoides, 85 .

Oxalis corniculata, 115.

Owl, 4.

\section{P.}

Pronia, 54.

Paints, or pigments, Egyptian, 25.

Palestine, 7, 154.

Pancratium Illyricum, and Pancratium maritimum, 29.

Pandanus odoratissimus, 35.

Panegyries, 158.

Panicum crus-galli, see Echinochloa.

Panicum colonum, 85.

Panicum Italicum, see Echinochloa.
Panicum miliaceum, 60.

Papal influence, 98, 104.

Papaver rhæas, 37.

Papaver somniferum, 43.

Papaya, 137.

Paper-rush, 10.

Papyri, rolls of, or books, 10, 13, 21, 24 .

Papyrus, the paper-rush, 10, 15.

Paremboleh, 83.

Parian Marble, 48, 49.

Parietaria officinalis, 77.

Parrot, 65.

Parsees, 43.

Parsley, 58.

Parsnip, 93.

Partridge, the red-legged, 4.

Passiflora cærulea, 143.

Passion-flower, see Passiflora.

Passover, 98, 165.

Pastinaca sativa, 93 .

Pavo, the peacock, 38 .

Pea, 63.

Pea, the field, 64 .

Peach, 81.

Peacock, 38.

Pea-nut, see Arachis, 142.

Pear, 26.

Peganum harmala, 41.

Pelargonium capitatum, 148.

Pelargonium zonale, 150.

Pennisetum typhoideum, 22.

Pentaptera arjuna, 121.

Peony, 54.

Peplis portula, 75 .

Pepper, 68.

Perdix, 4.

Perfumes, the traffic in, 5 .

Periploca Græca, 141.

Persepolis, antiquities at, 47.

Persia, 13, 21, 28, 33, 34, 40, 56 to 72 , $82,86,99,106,110,154,161$.

Peru, 138, 140, 142.

Petroselinum sativum, 58.

Phalaris Canariensis, 90.

Phaseolus mungo, 47.

Phaseolus vulgaris, the kidney-bean, 138.

Phasianus Colchicus, 63. 
I N D E X.

Pheasant, 63.

Philadelphus coronarius, 142.

Philæ, 25, 53, 54, 68, 81, 83, 86, 87, 88, $89,96,97,98$.

Philological observations, 154.

Phœnicia, 30, 35, 52.

Phonician, or Punic, inscriptions, 67.

Phœnix, 49, 155, 160, 162.

Phonix dactylifera, the date palm, 7, 15, 51 .

Phormium tenax, 151.

Phyllirea latifolia, 80.

Physalis alkekengi, 81.

Physalis somnifera, 71.

Physeter, 118.

Physicians, the ancient Egyptian, 5.

Phytolacea decandra, 149.

Phytolacca dioica, 151.

Picris altissima, 34 .

Pig, 9.

Pigeon, 30.

Pimpinella anisum, 56.

Pine, 44

Pineapple, 135.

Pine-nuts, 58.

Pinus deodara, 120.

Pinus Halepensis, 44.

Pinus maritima, 44.

Pinus pinea, 58.

Piper betel, 109.

Piper cubebs, 113.

Piper nigrum, black pepper, 68 .

Pistacia lentiscus, 62.

Pistacia terebinthus, 34 .

Pistacia vera, 75.

Pistia stratiotes, 74 .

Pisum arvense, 64.

Pisum sativum, 63.

Pittosporum tobira, 147.

Plane tree, 45.

Plantago coronopus, 94.

Plantago lagopus, 94.

Plantago major, 79.

Plantago psyllium, 89.

Plaster, or chunam, 5.

Platanus Orientalis, 45.

Plectranthus crassifolius, 120.

Plum, 55.
Po, the river, 46.

Poa annua, 133.

Poa eragrostis, 133.

Poa pilosa, 150.

Poetry, ancient Egyptian, 28; Greek, 36.

Poinciana pulcherrima, 147.

Poke, see Phytolacca decandra.

Pole-star, 168.

Polyanthes tuberosa, 144.

Polycarpon tetraphyllum, 133.

Polygonum aviculare, 84 .

Polygonum bistorta, 71 .

Polygonum fagopyrum, 137.

Polygonum Orientale, 150.

Polygonum persicaria, 123.

Polygonum salicifolium, 123

Polygonum tinetorium, 151.

Polynesians, 2, 11, 151.

Polypogon Monspeliense, 118.

Polytheism, 21.

Pomegranate, 14, 15.

Pompeii and Herculaneum, 81, 95.

Poplar, 26, 41.

Poppy, 37, 43.

Populus alba, 41.

Populus nigra, 26.

Populus tremula, 41.

Porcupine, 13.

Portraits of early Egyptian kings, 7, 11, $21,22,25,28,37,40$.

Portulaca oleracea, 75 .

Potato, 138.

Potentilla reptans, 66.

Potentilla supina, 66.

Poterium, 3.

Pottery, art of making, 9 ; ancient Greek, $31,47$.

Prangos pabularia, 73.

Prasium majus, 83.

Precession of the Equinoxes, 164.

Precious stones, the traffic in, 6.

Primulaceæ, not found in Egypt, 3.

Printing, art of, 129, 134.

Prunus Armeniaca, 81.

Prunus cerasus, 80 .

Prunus domestica, 55.

Psidium, 137. 
I N D E X.

Psittacus, 65.

Psoralea bituminosa, 60 .

Psoralea Palæstina, 60.

Psychotria emetica, 146.

Ptychotis ajowan, 68.

Pulex, 37.

Pumpkin, 142.

Punic, or Phœenician, inscriptions, 67.

Punica granatum, 14.

Purslain, 75.

Pyramids, 6, 11, 12, 13, 18, 19, 123.

Pyrethrum parthenium, 126.

Pyrethrum root, 84.

Pyrus communis, 26.

Pyrus malus, 39.

\section{Q.}

Quamamil, 88.

Quarries, at Tura, 11, 51; at Massara, 21 ; at Silsilis, 26; at Philæ, 98.

Quercus, 28.

Quercus suber, 58

Quicksilver, 65.

Quince, 42.

\section{R.}

\section{Rabbit, 18.}

Radish, 111.

Rafts of earthen jars, 9 .

Railroads, 153.

Ranunculus Asiaticus, 91.

Ranunculus sceleratus, 70 .

Rape-seed, 59.

Raphanus raphanistrum, 59.

Raphanus sativus, 111; var. oleifer., 59.

Rat, 138, 139

Rattans, 144.

Reaping grain, 10.

Red chalk, 11.

Reed, 11.

Registry of deeds, 86 .

Religions, foreign, introduced into Egypt, 20, 26, 93, 107, 120.

Reseda luteola, 87 .
Reseda phyteuma, 67.

Resedaceæ, numerous in Egypt, 3.

Revival of literature, 134.

Rhagadiolus edulis, 80 .

Rhamnus infectorius, 92.

Rheum, the drug rhubarb, 106.

Rheum Rhaponticum, 80

Rheum ribes, 116.

Rhine, the river, 94 .

Rhododendron lepidotum, 118.

Rhone, the river, 46.

Rhubarb, the garden, 80 .

Rhubarb, the drug, 106.

Rhus coriarea, 67.

Rhus cotinus, 53 .

Ribes floridum, 150 .

Ribes gracile, 144.

Ribes grossularia, 134 .

Ribes nigrum, 138.

Ribes rubrum, 138.

Rice, 73.

Ricinus communis, 61 .

River-flats of the Nile, 3 .

Robinia pseudacacia, 146.

Rocket, Brassica eruca, 76.

Rome, 24, 25, 26, 83, 99; date of the building of, 99,160 .

Rosaceæ, rare in Egypt, 3.

Rosaries, 25.

Rose, 40.

Rosemary, 33.

Rosetta stone, 83, 85, 159 .

Rosmarinus officinalis, 33

Rubia tinctorum, 68 .

Rubus fruticosus, 45 .

Rue, 64.

Rumex acetosa, 84 .

Rumex acetosella, 84 .

Rumex obtusifolius, 79 .

Rumex patientia, 57.

Rumex roseus, 39.

Ruscus hypophyllum.

Rushes, 11.

Russia, 151.

Ruta graveolens, 64 .

Ruta Halepensis, 64.

Rye, 10, 42. 
I N D E X.

S.

Saccharum officinale, 73.

Sacred Calendar, the Egyptian, 154 to 164.

Sacred festivals, Egyptian, 155.

Sacred numbers, Egyptian, 156, 164, 166.

Sacrifices, 8, 102.

Safflower, or dyers' saffron, 43.

Saffron, 25, 43.

Sahara, the Desert of, 2.

Sagapenum, 82.

Sage, 70 .

Sakhara, 7, 13, 53, 98.

Sainfoin, 141.

Salix Babylonica, 143.

Salix subserrata, 2, 45 .

Salsify, 80 .

Salsola articulata, 32.

Salsolaceæ, numerous in Egypt, 3.

Salvadora Persica, 24.

Salvia officinalis, 70 .

Samaria, 46, 50.

Samaritan letters, 67

Sambucus nigra, 67 .

San, or Zoan, 29.

Sanctuaries, 16.

Sandalwood, 104.

Sandstone of Silsilis, 26.

Sanscrit language, 154.

Santalum album, 104.

Santolina fragrantissima, 115 .

Sapindus laurifolius, 53.

Saponaria officinalis, 137.

Sarbut-el-Khadem, 25, 27, 31.

Sarcocol, 93.

Sarsaparilla, 137.

Sassafras, 143.

Satellites of Jupiter, 158.

Satureja? capitata, 65 .

Satureja juliana, 34.

Satureja thymbra, 62 .

Sauiet-el-Meitin, 14.

Saxifraga sarmentosa, 148.

Scabiosa prolifera, 3, 105.

Scammony, 29.

Scandinavian countries, 154 .

Scandix trichosperma, 65.
Scarabæi, of stone, 20.

Schech Said, 14.

Scilla maritima, 55 .

Scirpus lacustris, 139.

Scolymus Hispanicus, and Scolymus maculatus, 47.

Scorpiurus sulcata, 65 .

Scorpiurus villosa, 65 .

Scriptural names of plants, 41 .

Scurvy, 94.

Sebesten, see Cordia.

Secale cereale, 42.

Sedum confertum, 90.

Semecarpus anacardium, 97

Semneh, 18, 23.

Senecio Arabicus, 32.

Senecio squalidus, 120.

Senecio vulgaris, 32.

Senna, 34, 107.

Sepulchral images, 22

Sepulchral vases, 20.

Sesamum Orientale, 52.

Sesbania, see Eschynomene.

Setaria glauca, 132.

Setaria verticillata, 132 .

Setaria viridis, 132 .

Shaddock, 153.

Sheep, 8.

Shepherds, or Hyksos, 21.

Shoes, ancient Egyptian, 38.

Siam, 35.

Sicily, 113, 121.

Sicyos angulata, 149.

Sida abutilon, see Abutilon.

Sida mutica, 131.

Sida spinosa, 131.

Sieges of fortified places, 17, 22

Sienite, 11, 12, 16, 101.

Silene behen, 70 .

Silk, 73 .

Silkworm, 105.

Silsilis, 26, 27, 29, 40.

Silver, 25, 50, 100.

Sinai Peninsula, 6, 7, 11, 13, 14, 15, 19 , 25, 31, 38, 105 .

Sinapis alba, 56 .

Sinapis Allionii, 39. 


\section{N D E X.}

Sinapis juncea, 56 .

Sinapis nigra, 56 .

Sirius, the rising of, 159, 164, 165 .

Sium sisarum, 125.

Siut, tombs at, 20.

Skirret, 125.

Smallage, 45 .

Smilax aspera, 62 .

Smilax China, 139.

Smilax sarsaparilla, 137.

Smoking, the custom of, 140.

Smyrnium olusatrum, 72.

Snowball tree, 137.

Solanum Ethiopicum, 97.

Solanum coagulans, 39.

Solanum cordatum, 39.

Solanum dulcamara, 139.

Solanum lycopersicum, 140.

Solanum melongena, 112.

Solanum nigrum, 76.

Solanum pseudocapsicum, 132.

Solanum tuberosum, the potato, 138.

Soleb, 26.

Solidago virgaurea, 127.

Solstices, 155, 164.

Somali coun'ry, 33, 35, 62.

Sonchus oleraceus, 69.

Sorghum vulgare, 98.

Sorrel, 39, 84.

Spain, 110, 111.

Sparrow, 4.

Spartium monospermum, 38, 51.

Spelt, 10, 34.

Sphæranthus, 85.

Sphenoclea, 85 .

Spilanthes acmella, 148.

Spinach, 116.

Spinacia oleracea, 116.

Spinning and weaving, figured, 5.

Sponge, 46.

Squash, 142.

Squill, 55.

Stag, 18

Steam, 84, 152, 153.

Stellaria media, 123.

Sterculia platanifolia, 151.

Stomoxys, 34.

Stone parsley, 89

Storax, 33.

Strawberry, the European, 81 ; the North American, 145.

Strix flammea, 4 .

Sturgeon, 61 .

Strychnos nux vomica, 113.

Styrax officinalis, 33 .

Suæda baccata, 50 .

Suæda hortensis, 32.

Succory, 57.

Sugar, from Asclepias procera, 33.

Sugar-cane, 73.

Sunflower, 141.

Sweet potato, 134.

Swine, 9.

Sycamore, 23.

Syene, or Assuan, 15, 96.

Syria, 30 .

Syringa vulgaris, 121.

$\mathrm{T}$.

Tagetes, 138.

Talmis, 87,89 .

Tamarindus Indica, 106.

Tamarix, 2.

Tamil language, 35, 38.

Tanacetum vulgare, 112.

Tanks, or artificial ponds, 23.

Tansy, 112.

Taro, 85 .

Tarragon, 112.

Tartars, 124, 126, 128.

Taxes, 20.

Tea, 114.

Teak, 74 .

Teazle, 93.

Tectona grandis, 74 .

Temple, the most ancient, 16 ; formal destruction of Heathen temples, 103.

Terebinth tree, 34 .

Terminalia, 153.

Terminalia belerica, 110 .

Terminalia Chebula, 111.

Terminalia? vernix, 127.

Teucrium chamædrys, 77.

Teucrium iva, see Ajuga. 
1 N D E X.

Teucrium marum, 92.

Teucrium polium, 46.

Teucrium scordium, 86 .

Thalia dealbata, 152.

Thapsia, 82 .

Thapsia silphium, 53.

Thea, 114.

Thebes, 15, 16, 25, 28, 29, 30, 37, 53, 82, $86,87,93,96$.

Theobroma cacao, 139.

Thibet, 104, 114.

Thistles, 37, 60 .

Thlaspi bursa-pastoris, 70 .

Thuya Occidentalis, 139.

Thuya Orientalis, 44 .

Thyme, 59.

Thymus serpillum, 59 .

Tiger, figured, 18.

Tigridia pavonia, 142.

Tilia Europæa, 63.

Timber, in some of the Pyramids, 6; imported into Yemen, 38.

Time, divisions of, 159, 165; the Egyptian measurement of, 154 .

Tin, 15, 16.

Tobaceo, 140.

Tomato, 140.

Torilis anthriscus, 121.

Tortoise-shell, 73.

Tragacanth, 77.

Tragopogon porrifolius, 80 .

Transmigration, the doctrine of, 20.

Tribulus terrestris, 77.

Trifolium Alexandrinum, 76.

Trifolium procumbens, 134 .

Trifolium resupinatum, 94 .

Trigonella fonum græcum, 43.

Trigonella hamosa, 43.

Tripods, 36.

Triticum hybernum, wheat, 10.

Triticum repens, 150.

Triticum spelta, 10, 34 .

Tropæolum minus, 142.

Troy, 36.

Trumpet-flower, 146.

Tuberose, 144.

Tulip, 140.
Tulipa Gesneriana, 140

Tura, the quarries at, $11,51,67$.

Turkey, the domestic, 135.

Turkey berries, 92 .

Turmeric, 39 .

Turnip, 64.

Turks, 105, 125, 127, 129.

Turpeth, 109.

Turtle, 73.

Typha, 11.

\section{U}

Ulmus campestris, 44 .

University, Arab, 119.

Urtica dioica, 61 .

Urtica nivea, 148.

Urtica pilulifera, 64 .

Urtica urens, 64 .

Uvaria aromatica, 72 .

\section{V.}

Vachellia Farnesiana, see Acacia.

Valerian, 57.

Valeriana Celtica, 57.

Valeriana Dioscoridis, 57.

Valerianaceæ, not found in Egypt, 3.

Vanilla, 149.

Vegetation, the Egyptian, 2.

Vella annua, 133.

Verbascum sinuatum, 63.

Verbena citriodora, see Aloysia.

Verbena officinalis, 130.

Verbena supina, 130.

Vermilion, 65.

Veronica anagallis, 94.

Veronica beccabunga, 94 .

Vesuvius, eruption of, 95 .

Vetch, 42.

Viburnum opulus, 137.

Vicia faba, the bean, 37 .

Vicia lutea, 69.

Vicia sativa, 42.

Vinca rosea, 147.

Vine, 10.

Viola odorata, 46. 


\section{N D E X.}

Viola tricolor, 137.

Violaceæ, not found in Egypt, 3.

Vitex agnus-castus, 43 .

Vitis vinifera, 10.

Viverra genetta, 3 .

Viverra zibetha, 122 .

Vocal Memnon, the statue, 87, 96, 97, 160 .

Vulpes, 8.

W.

Wadi-el-Moyeh, 27.

Wadi Halfa, 23, 25, 27.

Wadi Maghara, 6, 7, 11, 13, 14, 15, 19.

Walnut, 39.

Wars, see Military Campaigns.

Water-cress, 86.

Water-melon, 14, 15.

Weaving and spinning, figured, 5 .

Weeds on the river-flats of the Nile, 3 .

Weights and measures, 13.

West Indies, aboriginals of, 134, 135, 136.

Whales, 118.

Wheat, 10 .

White Race, figured, 7, 11, 13, 17, 22, 24.

Willow, 2, 45 .

Willow, the weeping, 143

Wine, the art of making, 10 .

Woad, 87.

Woodwork, ornamental, 30 .

Words, the geographical diffusion of, 154 .

Woven cloth, 5 .
Writing, the art of, $4,7,11$

Writing-tablets, 44 .

\section{X.}

Xanthium spinosum, 147

Xanthium strumarium, 91.

Y.

Yak, or mountain-bullock of Thibet.

Yam, 135.

Yarrow, or milfoil, 112.

Yemen, 15, 18, 24, 32, 35, 38, 49, 62, 129

Yucea aloifolia, 144

$\mathrm{Z}$.

Zakkoum oil, 107

Zanzibar, 38, 88, 118.

Zapania nodiflora, 144.

Zea mays, 47, 135.

Zeduary, 96.

Zingiber officinale, see Ginger.

Zizyphus lotus, 22.

Zizyphus vulgaris, 89 .

Zoan, or San, 29.

Zodiacal projections, 68.

Zoological science, 17.

Zygophyllaceæ, numerous in Egypt, 3.

Zygophyllum coccineum, 120. 





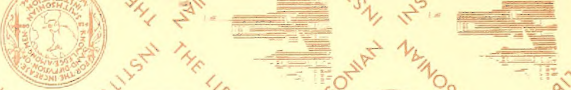

$\left(x^{2}=\right.$

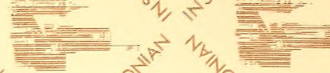

(1)

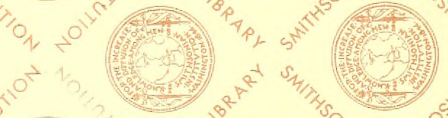

(a) $\Rightarrow=$

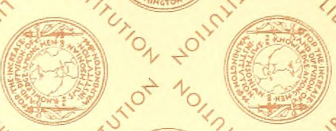

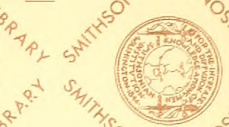

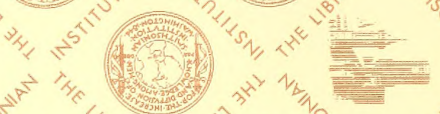

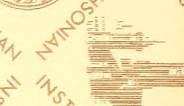

the

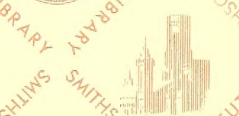

(c)

(7.9.

IfI

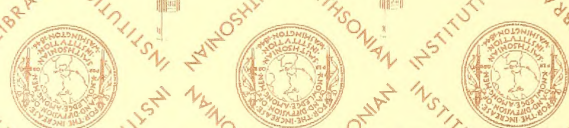

scind

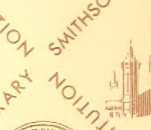

th
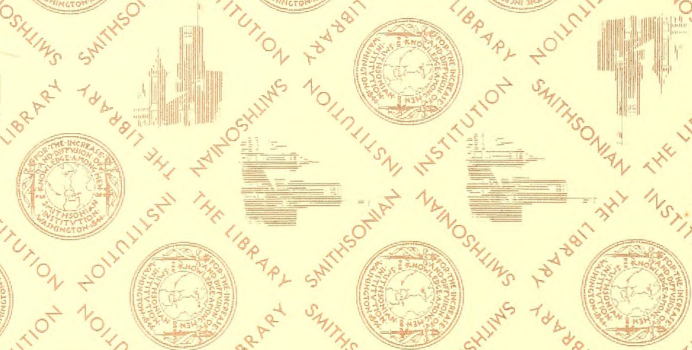

7

Int
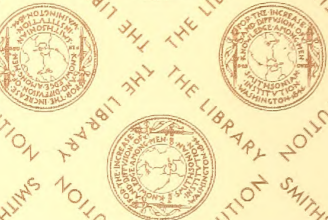

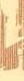
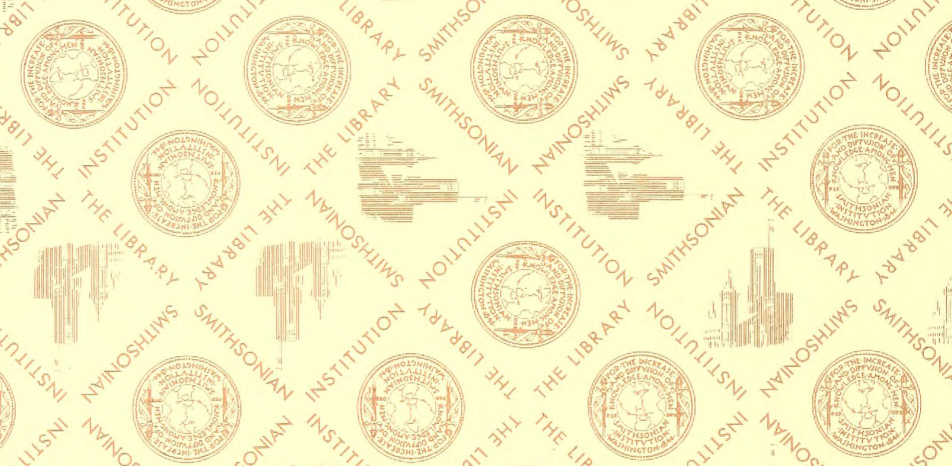

Al
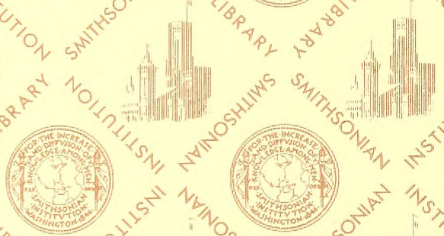

(5)
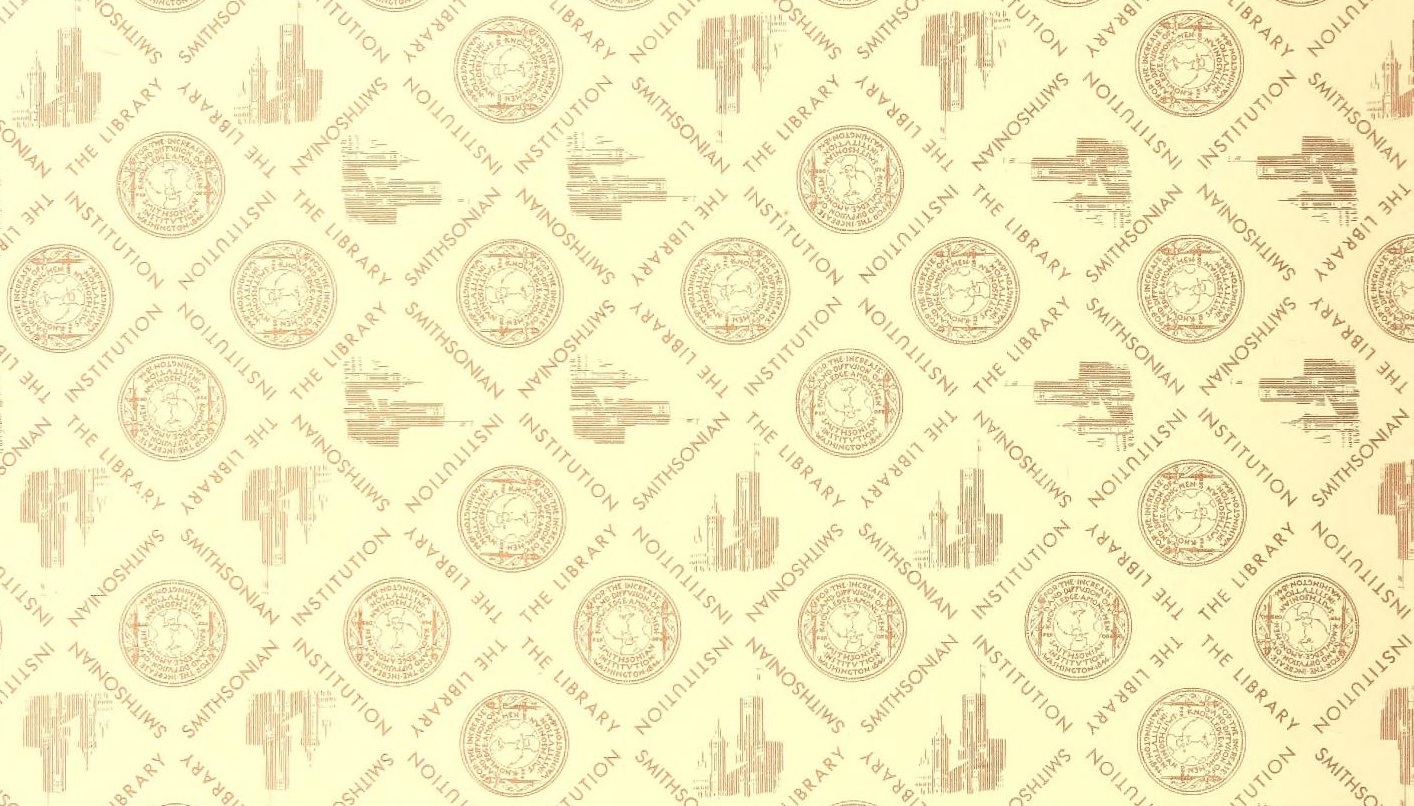

(3)
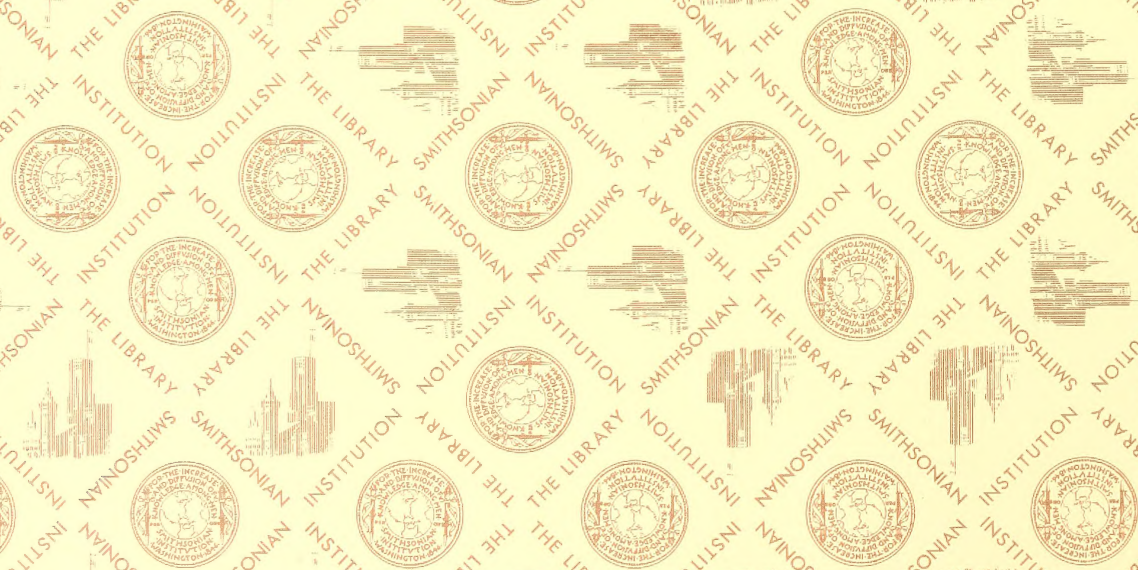

$\frac{\omega^{5}}{2 / / 2}$

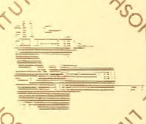

tin
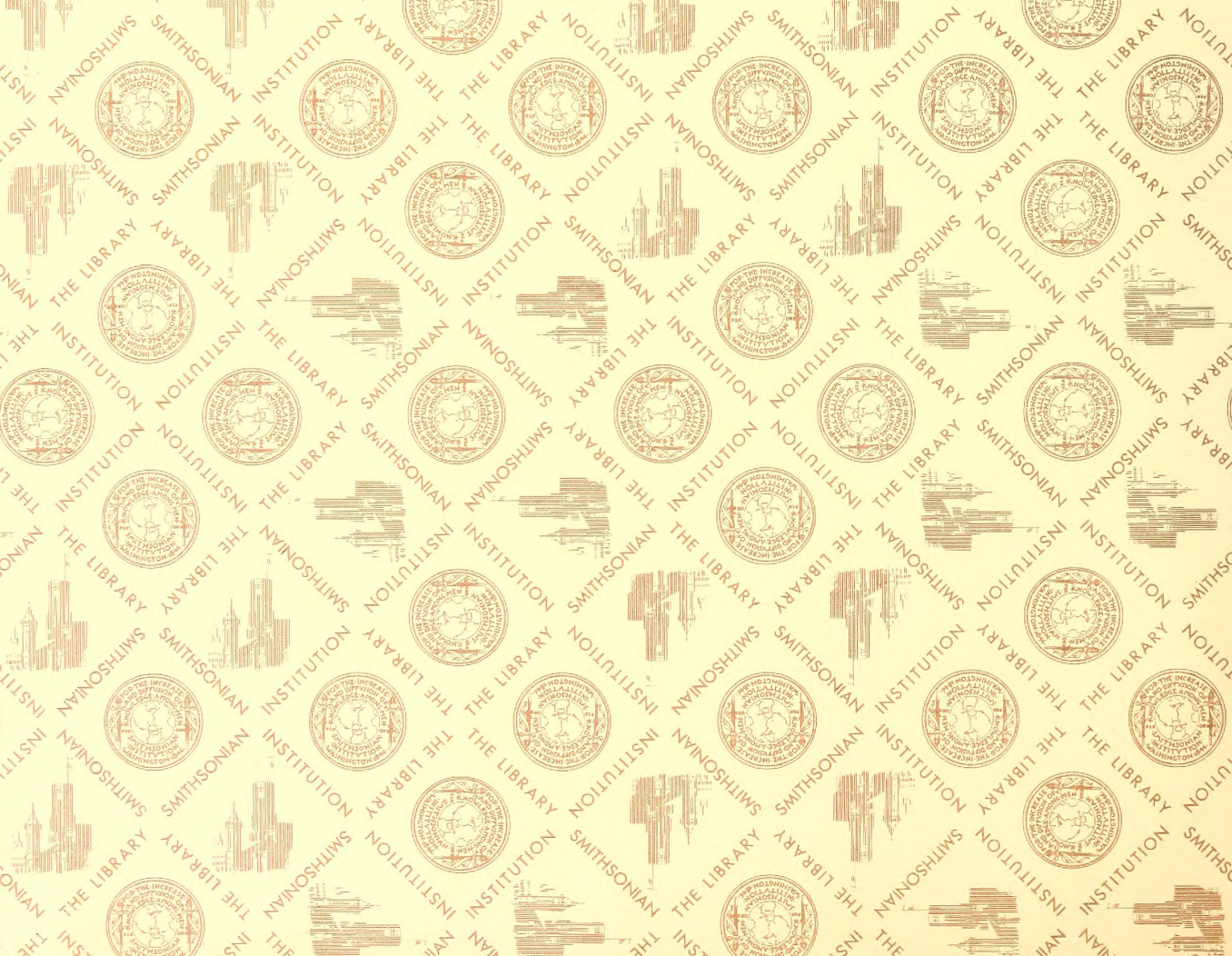

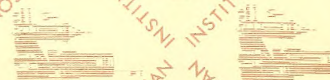

$(73)^{3}=6$

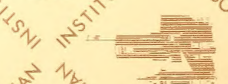


